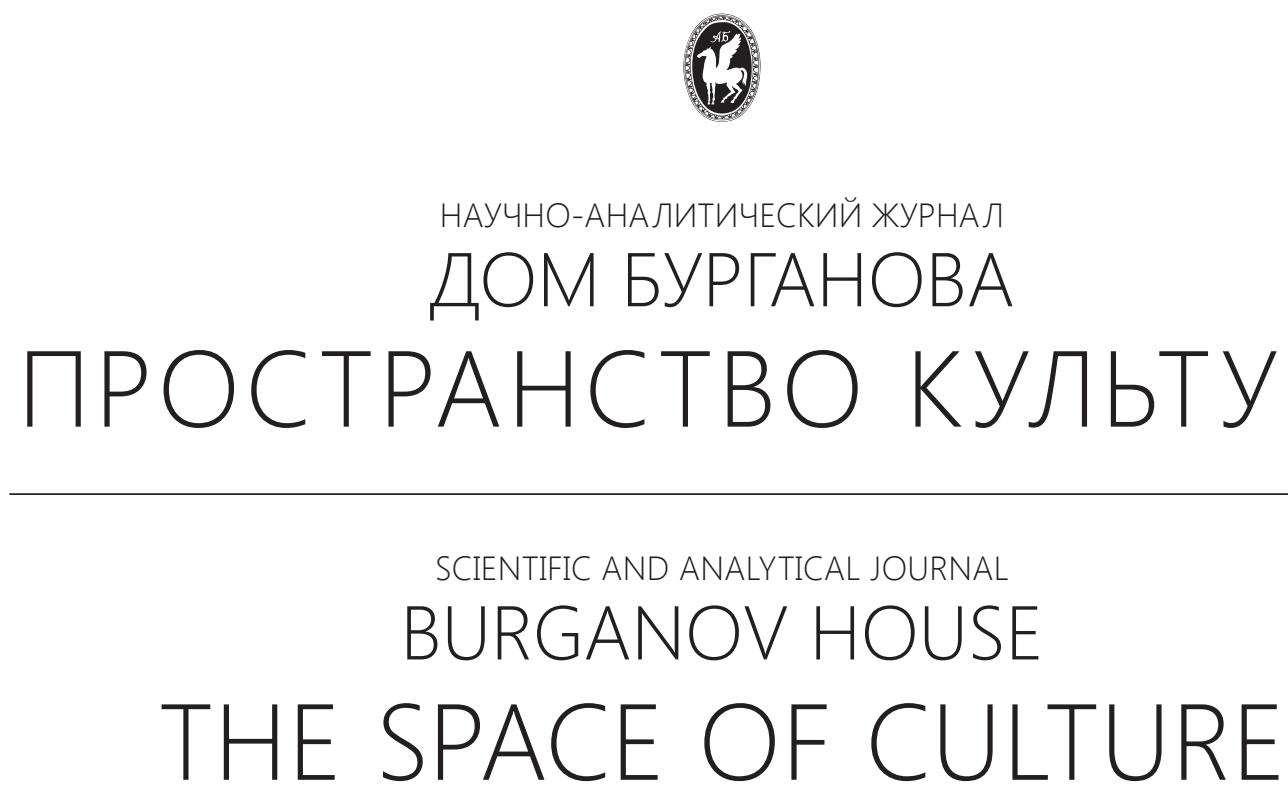

По рекомендации экспертного совета Высшей аттестационной комиссии Министерства образования и науки Российской Федерации журнал входит в «Перечень ведущих рецензируемых научных журналов и изданий, в которых должны быть опубликованы основные научные результаты диссертации на соискание ученой степени доктора и кандидата наук» 


\section{The Editorial Board:}

Bowlt John Ellis

(USA)

Burganov Alexander N. (Russia)

Burganova Maria A. (Russia)

Gao Meng

(China)

Glanc Tomáš

(Germany)

Kravetsky Alexander G. (Russia)

Kojo Sano

(Japan)

Misler Nicoletta

(Italy)

Pan Yaochang

(China)

Pavlova Irina B.

(Russia)

Perelshtein Roman M. (Russia)

Pletneva Alexandra A. (Russia)

\section{Pociechina Helena}

(Poland)

Pruzhinin Boris I.

(Russia)

Ryzhinsky Alexander S. (Russia)

Sahno Irina M.

(Russia)

Smolenkov Anatoly P. (Russia)

Smolenkova Julia A (Russia)

Tanehisa Otabe

(Japan)

Tsivian Yuri G. (USA)
- Doctor of Science, Professor of the University of Southern California; Founder and head of the Institute of Modern Russian Culture

- Doctor of Science, Professor of Stroganov Moscow State Art Industrial Academy, Fullmember of Russia Academy of Arts

- Doctor of Science, Professor of Stroganov Moscow State Art Industrial Academy, Fullmember of Russia Academy of Arts

- Doctor of Science, Professor of Guangzhou Academy of fine arts

- Doctor of Science of The Research Institute of East European University of Bremen (Germany), and assistant professor of The Charles University (Czech Republic)

- Candidate of Sciences, research associate of Russian Language Institute of the Russian Academy of Sciences

- Professor of Toho Gakuyen University of Music

- Professor of Modern East European Art at the Instituto Universitario Orientale, Naples

- Professor of the Department of Art History and Art Theory of College of Fine Arts in Shanghai University; member of the Academic Committee of the Shanghai University

- Doctor of Philology, Senior Researcher of Institute of World Literature of the Russian Academy of Sciences

- Doctor of Arts, All-Russia State Institute of Cinematography named after S. A. Gerasimov

- Candidate of Sciences, research associate of Russian Language Institute of the Russian Academy of Sciences

- Doctor of Science; Professor of the University of Warmia and Mazury in Olsztyn

- Doctor of Sciences, Professor, editor-in-chief of the Journal Problems of Philosophy

- Doctor of Science, Professor of Gnesins Russian Academy of Music

— Doctor of Sciences, Professor of Peoples' Friendship University of Russia

- Candidate of Sciences, Professor of Stroganov Moscow State Art Industrial Academy, full-member of Russia Academy of Arts

- Candidate of Sciences, associate professor of Stroganov Moscow State Art Industrial Academy

- Doctor of Science, Professor, Head of Department of Aesthetics and Theories of Art. The University of Tokyo

- Doctor of Science, Professor, University of Chicago, Departments: Cinema and Media Studies, Art History, Slavic Languages and Literatures 
SCIENTIFIC AND ANALYTICAL JOURNAL "BURGANOV HOUSE. SPACE OF CULTURE"
No. 2

SUMMER 2021
EASTERN MEDIEVAL ARCHITECTURE. RUSSIA

BY ROBERT G. OUSTERHOUT

THE LIAR'S PARADOX - A WILD INTERATION P.2. DIPHTHONG DIPHTHONG ARISTOTLE-ANOKHIN BY ELENA R. MENSHIKOVA

CULTURAL BACKGROUND OF CARVED STONE SCULPTURE OF ANCIENT CHINESE MAUSOLEUMS BY XIANG WU

HAN-ERA FUNERARY ART OBJECTS - WORKS OF BRONZE. HAN-ERA BRONZE AESTHETICS BY QIU MUBING

THE HWAJOHWA GENRE (BIRD-AND-FLOWER PAINTING) IN KOREAN TRADITIONAL PAINTING OF THE EARLY AND MIDDLE JOSEON PERIODS (LATE $14^{\text {TH }}-$ LATE $17^{\text {TH }}$ CENTURIES) BY EKATERINA A. VOSTRIKOVA

THE IMAGE OF THE ICON IN THE WORKS OF THE SEVERE STYLE ARTISTS BY PETR P. KOZOREZENKO

MOSCOW METRO OF ALENA DERGILIOVA IMAGE OF STABILITY AND FEATURES OF CHANGE BY NIKOLAY P. BESCHASTNOV \& EVDOKIA N. DERGILIOVA

HISTORY AND ART PIECES IN THE FILM "ALEXANDER NEVSKY" BY SERGEI EISENSTEIN BY NIKITA P. LUSHCHENKOV

REACTUALISATION OF THE RITUAL STRUCTURE IN THE PERFORMANCE OF JERZY GROTOWSKI'S SHAKUNTALA BY KALIDASA (1960) BY POLINA M. STEPANOVA

PROJECT CULTURE OF TEAM STRATEGIES BY YULIA A. VASERCHUK
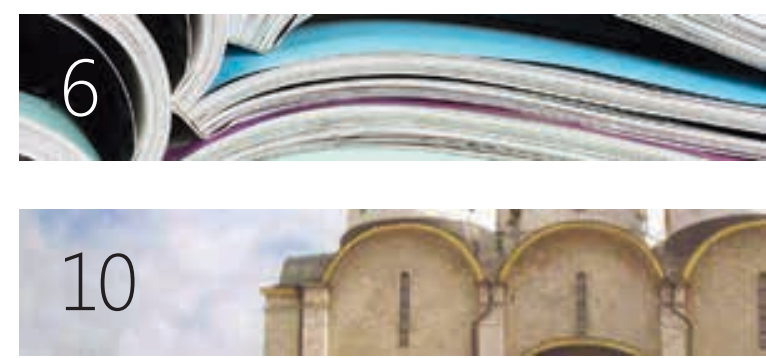

\section{8}
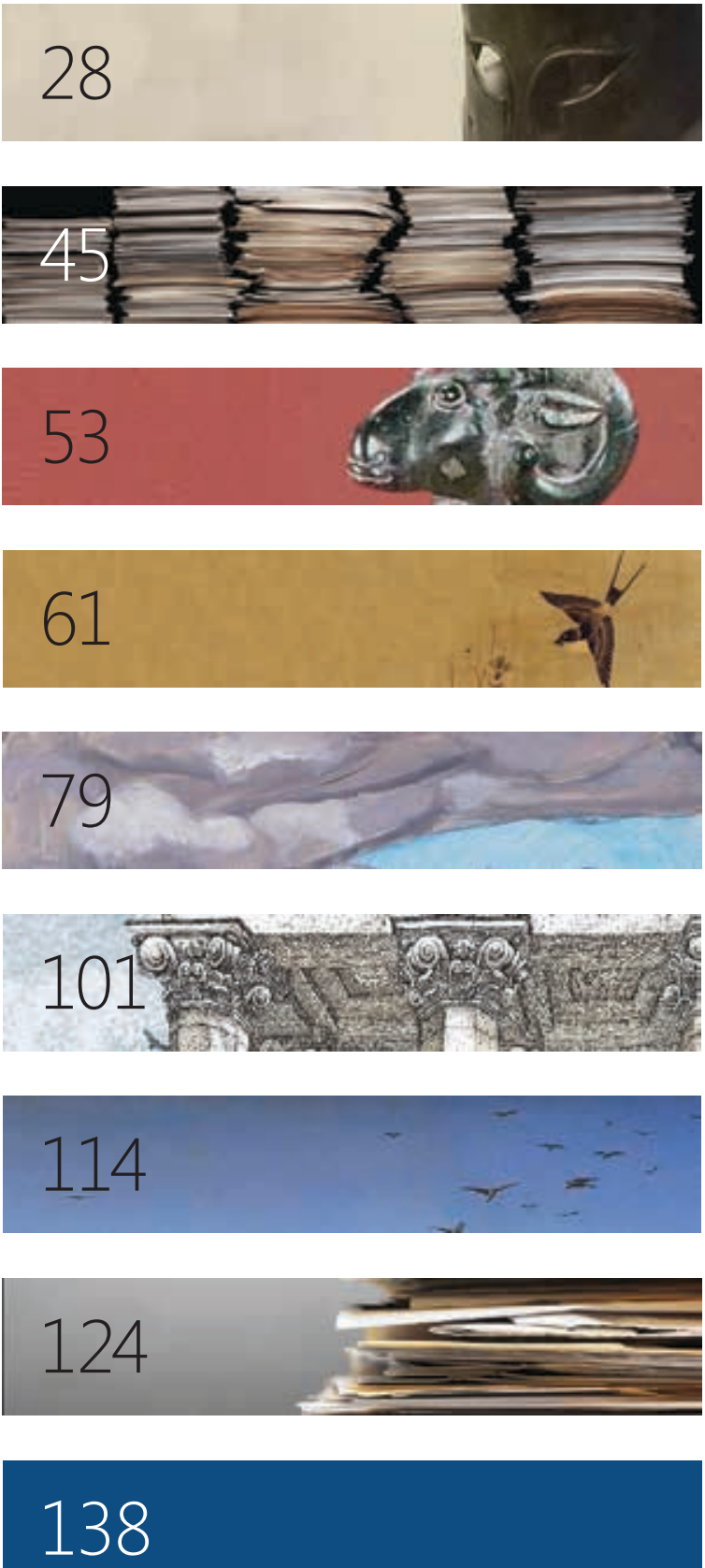


\section{Редакционный совет:}

\author{
Боулт Джон Эллис \\ (США) \\ Бурганов Александр Николаевич \\ (Россия)
}

Бурганова Мария Александровна (Россия)

\section{Гао Мэн}

(Китай)

\section{Гланц Томаш}

(Германия)

Кравецкий Александр Геннадиевич (Россия)

\section{Койо Сано}

(Япония)

\section{Мислер Николетта \\ (Италия)}

\section{Пан Яочанг \\ (Китай)}

\section{Павлова Ирина Борисовна \\ (Россия)}

\author{
Перельштейн Роман Максович \\ (Россия)
}

\author{
Плетнева Александра Андреевна \\ (Россия)
}

\section{Почехина Елена \\ (Польша)}

\author{
Пружинин Борис Исаевич \\ (Россия)
}

\section{Рыжинский Александр Сергеевич (Россия)}

\author{
Сахно Ирина Михайловна \\ (Россия)
}

\author{
Смоленков Анатолий Петрович \\ (Россия)
}

\author{
Смоленкова Юлия Анатольевна \\ (Россия)
}

\section{Танехиса Отабе \\ (Япония)}

\section{Цивьян Юрий Гаврилович (США)}

- доктор наук, профессор Университета Южной Калифорнии, создатель и директор Института современной русской культуры

- доктор искусствоведения, академик Российской академии художеств, профессор Московской государственной художественно-промышленной академии им. С. Г. Строганова

- доктор искусствоведения, профессор Московской государственной художественно-промышленной академии им. С.Г. Строганова, академик Российской академии художеств

- доктор наук, профессор, Guangzhou Academy of fine arts

- доктор, научный сотрудник Исследовательского центра Восточной Европы Бременского университета, профессор The Charles University (Чехия)

- кандидат филологических наук, ведущий научный сотрудник Института русского языка Российской академии наук

- професcop, Toho Gakuyen University of Music

— профессор, Instituto Universitario Orientale, Naples

- профессор кафедры истории и теории искусства колледжа Изящных искусств Шанхайского Университета, член Академического комитета Шанхайского Университета

- доктор филологических наук, старший научный сотрудник Института мировой литературы РАН

- доктор искусствоведения, Всероссийский государственный институт кинематографии им. С.А. Герасимова

- кандидат филологических наук, научный сотрудник Института русского языка Российской академии наук

- доктор наук, профессор, University of Warmia and Mazury in Olsztyn

- доктор философских наук, профессор, главный редактор журнала «Вопросы философии»

- доктор наук, профессор Российской академии музыки им. Гнесиных

- доктор филологии, профессор Российского университета Дружбы народов

- кандидат искусствоведения, профессор Московской государственной художественно-промышленной академии им. С. Г. Строганова, академик Российской академии художеств

- кандидат искусствоведения, доцент Московской государственной художественно-промышленной академии им. С. Г. Строганова

- доктор наук, профессор, заведующий кафедры Эстетики и теории искусства Токийского университета

- доктор наук, профессор, University of Chicago, Departments: Cinema and Media Studies, Art History, Slavic Languages and Literatures 


\section{СОДЕРЖАНИЕ}

НАУЧНО-АНАЛИТИЧЕСКИЙ ЖУРНАЛ «ДОМ БУРГАНОВА ПРОСТРАНСТВО КУЛЬТУРЫ»

\section{СЛОВО РЕДАКТОРА}

РОБЕРТ ДЖ. ОУСТЕРХАУТ ВОСТОЧНАЯ СРЕДНЕВЕКОВАЯ АРХИТЕКТУРА РОССИЯ

ЕЛЕНА РУДОЛЬФОВНА МЕНЬШИКОВА ПАРАДОКС ЛГУНА - НЕВЕРОЯТНОЕ ПОВТОРЕНИЕ

4.2. ДИФТОНГ АРИСТОТЕЛЬ-АНОХИН

$\mathrm{CAH} \mathrm{Y:}$

КУЛЬТУРНЫЕ ПРЕДПОСЫЛКИ К ФОРМИРОВАНИЮ КАМЕННОЙ РЕЗНОЙ СКУЛЬПТУРЫ В ДРЕВНЕКИТАЙСКИХ МАВЗОЛЕЯХ

ЦЮ МУБИН

ПРЕДМЕТЫ ПОГРЕБАЛЬНОГО КУЛЬТА В ЭПОХУ ХАНЬ ИЗДЕЛИЯ ИЗ БРОНЗЫ. ЭСТЕТИКА БРОНЗЫ В ЭПОХУ ХАНЬ

ЕКАТЕРИНА АЛЕКСАНДРОВНА ВОСТРИКОВА ЖАНР ХВАДЖОХВА («ЦВЕТЫ И ПТИЦЫ») В КОРЕЙСКОЙ ТРАДИЦИОННОЙ ЖИВОПИСИ РАННЕГО И СРЕДНЕГО ПЕРИОДОВ ЧОСОН (КОНЕЦ XIV — КОНЕЦ XVII ВВ.)

ПЕТР ПЕТРОВИЧ КОЗОРЕЗЕНКО: ОБРАЗ ИКОНЫ В ТВОРЧЕСТВЕ ХУДОЖНИКОВ «СУРОВОГО СТИЛЯ»

НИКОЛАЙ ПЕТРОВИЧ БЕСЧАСТНОВ ЕВДОКИЯ НИКОЛАЕВНА ДЕРГИЛЁВА МОСКОВСКОЕ МЕТРО АЛЁНЫ ДЕРГИЛЁВОЙ

ОБРАЗ СТАБИЛЬНОСТИ И ЧЕРТЫ ПЕРЕМЕН

НИКИТА ПАВЛОВИЧ ЛУЩЕНКОВ ИСТОРИЯ И ЖИВОПИСНЫЙ ОБРАЗ В ФИЛЬМЕ «АЛЕКСАНДР НЕВСКИЙ СЕРГЕЯ ЭЙЗЕНШТЕЙНА

ПОЛИНА МИХАЙЛОВНА СТЕПАНОВА: РЕАКТУАЛИЗАЦИЯ РИТУАЛЬНОЙ СТРУКТУРЬ В СПЕКТАКЛЕ ЕЖИ ГРОТОВСКОГО «САКУНТАЛА» КАЛИДАСЫ (1960)

ЮЛИЯ АНАТОЛЬЕВНА ВАСЕРЧУК: ПРОЕКТНАЯ КУЛЬТУРА КОМАНДНЫХ СТРАТЕГИЙ
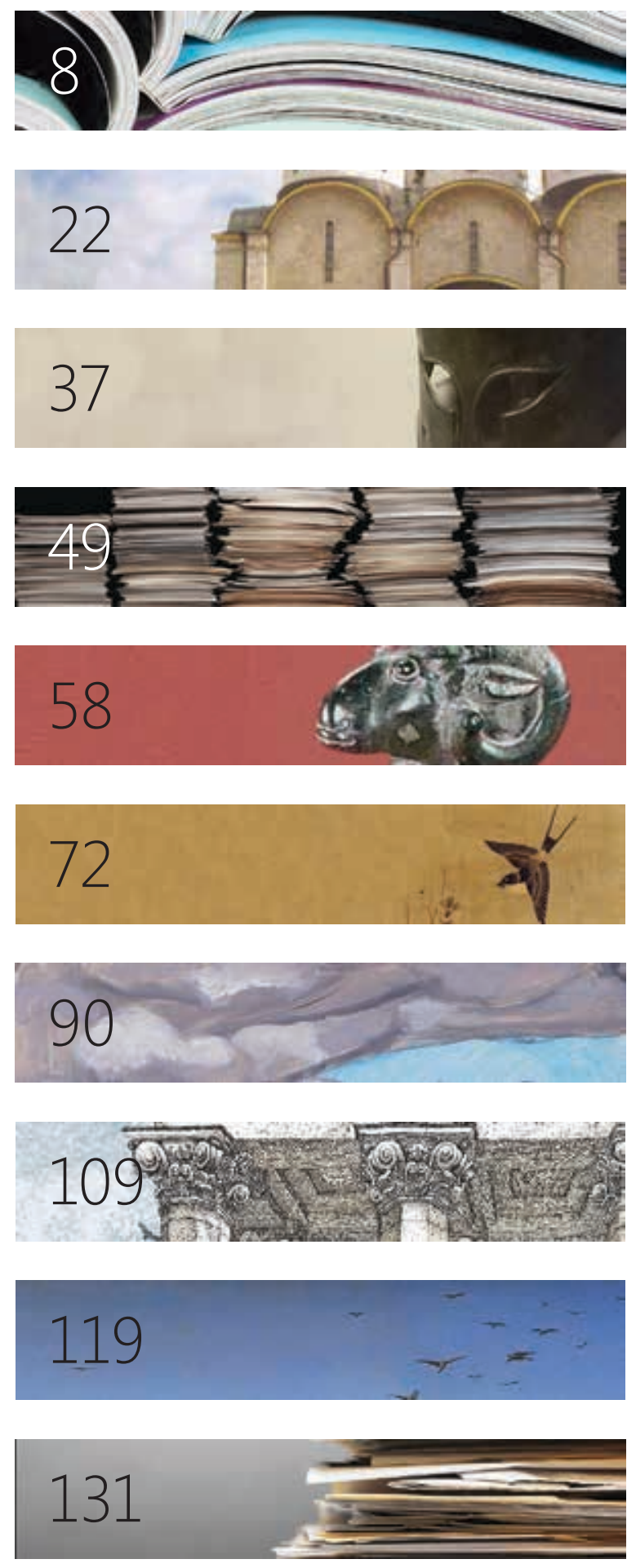

\section{4}




\section{LETTER \\ FROM \\ THE EDITOR}

Scientific and Analytical Journal

Burganov House

Space of culture

\#2/2021
Dear readers,

We are pleased to present to you Issue 2, 2021, of the scientific and analytical journal Burganov House. The Space of Culture.

Upon the recommendation of the Expert Council of the Higher Attestation Commission, the journal is included in the List of Leading Peer-reviewed Scientific Journals and Publications in which the main scientific results of theses for the academic degrees of doctor and candidate of science must be published.

The journal publishes scientific articles by leading specialists in various humanitarian fields, doctoral students, and graduate students. Research areas concern topical problems in multiple areas of culture, art, philology, and linguistics. This versatility of the review reveals the main specificity of the journal, which represents the current state of the cultural space.

The article by the outstanding American historian of architecture, Robert Ousterhout, is devoted to the Russian architecture formation and questions of church construction development.

E. Menshikova analyses the issues of ancient aesthetics and philosophy through the prism of the realities of the modern world in the article "The Paradox of a Liar - an Incredible Repetition. Part II. The Aristotle-Anokhin Diphthong".

Characteristic of the religious consciousness and philosophy of Confucianism, the ideas of the immortality of the spirit, filial piety, and etiquette, which have become firmly established in the burial culture of Ancient China, are explored by Xiang Wu in his article "Cultural Preconditions for the Formation of Stone Carved Sculpture in Ancient Chinese Mausoleums".

Qiu Mubing continues the theme of the Chinese funerary tradition of the Han period in the article "Items of Burial Cult in the Han Period. Bronze Items. Bronze Aesthetics in the Han Period". The author analyses bronze items and concludes that the Bronze Age in China began with the emergence of Chinese civilisation and lasted, developing in stages, until the end of the period in question - the Han period.

E. Vostrikova analyses the stylistic evolution of the Flowers and Birds genre in her article "The Hwajohwa Genre ("Flowers and Birds") in Korean Traditional Painting of the Early and Middle Joseon Periods (Late 14th - Late 17th Centuries)". The study identifies the historical and cultural context and the main terms for its designation, presents individual 
artistic trends, examines the techniques used in Korean traditional painting. Moreover, the author outlines the leading artists who worked in this genre during the indicated period.

P. Kozorezenko investigates the artistic searches of the masters of the Severe style in the article "The Image of an Icon in the Art of the Artists of the Severe Style". The author believes that ancient Russian art and its main embodiment, an icon, are one of the vivid elements of the creative palette of the Severe style masters.

$\mathrm{N}$. Beschastnov and E. Dergileva present the graphic heritage of Moscow artist A. Dergileva, limited by the period between 1980-1990, in the article "The Moscow Metro of Alena Dergileva: the Image of Stability and Features of Change". The seemingly simple theme, "man and a city", is developed in a multitude of complex relationships between plastic and compositional research.

In the article "History and the Picturesque Image in Sergei Eisenstein's Film Alexander Nevsky", $\mathrm{N}$. Lushchenkov examines the theme of picturesque images in films. The author analyses the dialogue of different types of art on the example of the film Alexander Nevsky, believing that these not so obvious, but deep in their idea and artistic structure, allusions to works of painting, book illustration and graphics manifest themselves most vividly and consistently in the context of the film.

The fundamentals of the sacred space reconstruction on the example of the play Shakuntala are considered by P. Stepanova in the article "Reactualization of the Ritual Structure in the Performance of Jerzy Grotowsky's Shakuntala by Kalidasa (1960)". The author explores the main methods of working on new connections between the actor and the audience in a theatrical performance as a special form of complicity. The author considers the deconstruction of the stage space and the removal of a clear division into the stage and the audience to be one of the main means of expression at this stage of work.

In the article "Design Culture of Team Strategies", Y. Vaserchuk analyses modern forms of design activity that contribute to professional design development and compares the principles of designers' teamwork that are similar in form but differ in content. The author identifies the types of project design thinking: from engineering and creative types to artistic and resource-based ones.
The publication is addressed to professionals specialising in the theory and practice of the fine arts and philology and all those interested in the arts and culture. 


\section{СЛОВО \\ РЕДАКТОРА}

Научно-аналитический журнал

Дом Бурганова

Пространство культуры

\#2/2021

\section{Дорогие читатели!}

Мы рады представить Вам № 2/2021 научноаналитического журнала «Дом Бурганова. Пространство культуры».

По рекомендации Экспертного совета ВАК журнал включен в Перечень ведущих рецензируемых научных журналов и изданий, в которых должны быть опубликованы основные научные результаты диссертации на соискание учёных степеней доктора и кандидата наук.

В журнале публикуются научные статьи ведущих специалистов разных гуманитарных областей, докторантов и аспирантов. Направления исследований касаются актуальных проблем в различных областях культуры, искусства, филологии и языкознания. В этой многогранности обозрения проявилась основная специфика журнала, представляющего современное состояние пространства культуры.

Статья выдающегося американского историка архитектуры Р. Оустерхаута посвящена становлению русской архитектуры и вопросам формообразования храмового строительства.

Е.Р. Меньшикова в статье «Парадокс лгуна невероятное повторение. Часть II. «Дифтонг Аристотель-Анохин»» анализирует вопросы античной эстетики и философии сквозь призму реалий современного мира.

Характерные для религиозного сознания и философии Конфуцианства идеи о бессмертности духа, сыновней почтительности, этикете, которые прочно вошли в погребальную культуру Древнего Китая исследует Сян У в статье «Культурные предпосылки к формированию каменной резной скульптуры в древнекитайских мавзолеях».

Тему китайской погребальной традиции периода Хань продолжает Цю Мубин в статье «Предметы погребального культа в эпоху Хань - изделия из бронзы.

Эстетика бронзы в эпоху Хань». Автор анализирует изделия из бронзы и делает вывод, что в Китае бронзовый век начался с возникновением китайской цивилизации и длился, развиваясь поэтапно, до конца исследуемого периода - эпохи Хань.

Стилевую эволюцию жанра «цветы и птицы анализирует Е.А. Вострикова в статье «Жанр хваджохва («цветы и птицы») в корейской традиционной живописи раннего и среднего периодов Чосон (конец XIV — конец XVII вв.)». 
В исследовании обозначен историко-культурный контекст, выявлены основные термины для его обозначения, представлены отдельные художественные направления, рассмотрены техники и приёмы, применявшиеся в корейской традиционной живописи. Автор также очерчивает основной круг художников, работавших в данном жанре в обозначенный период.

Анализ художественных поисков мастеров «сурового стиля» исследует П.П. Козорезенко в статье «Образ иконы в творчестве художников «сурового стиля»». Автор полагает, что одним из ярких элементов творческой палитры

мастеров «сурового стиля» стало древнерусское искусство и его главное воплощение - икона.

Н.П. Бесчастнов и Е.Н. Дергилёва в статье «Московское метро Алёны Дергилёвой: Образ стабильности и черты перемен» представляют графическое наследие московского художника А. Дергилёвой, ограниченное рамками 19801990 гг. Внешне простая тема «человек и город" решается во множестве сложных взаимоотношений пластических и композиционных изысканий.

Н.П. Лущенков в статье «История и живописный образ в фильме «Александр Невский» Сергея Эйзенштейна» рассматривает тему живописных образов в кино. Автор анализирует диалог разных видов искусств на примере фильма «Александр Невский», полагая, что эти не столь явные, но глубокие по своей идее и художественному строю аллюзии на произведения живописи, книжной иллюстрации и графики проявляют себя в контексте фильма наиболее ярко и последовательно.

Фундаментальные основы реконструкции сакрального пространства на примере спектакля «Сакунтала» рассматривает П. М. Степанова в статье «Реактуализация ритуальной структуры в спектакле Ежи Гротовского «Сакунтала» Калидасы (1960)». Автор исследует основные приёмы работы над новыми связями между актером и зрителем в ходе театрального представления как особой формы соучастия. Одним из главных выразительных средств на этом этапе работы автор считает деконструкцию сценического пространства и избавление от чёткого разделения на сцену и зрительный зал.

Ю.А. Васерчук в статье «Проектная культура командных стратегий» анализирует современные формы дизайнерской деятельности, способствую- щие развитию профессионального проектирования, и сопоставляет близкие по форме, но отличающиеся по содержанию принципы коллективной работы проектировщиков. Автор выделяет типы проектного дизайн-мышления: от инженерного, креативного - до художественного и ресурсного.

Издание адресовано профессионалам, специализирующимся в области теории и практики изобразительного искусства и филологии, а также всем, кто интересуется вопросами искусства и культуры. 
Robert G. Ousterhout

Professor Department of the History of Art

Director of the Centre for Ancient Studies

University of Pennsylvania

Philadelphia, USA

ORCID 0000-0002-4323-2296

\section{EASTERN MEDIEVAL ARCHITECTURE. RUSSIA}

We publish in this issue the continuation of the translation of the new book of the outstanding historian of the architecture of Byzantium professor of Penn University (USA) and professor honoris causa of the Moscow Institute for Architecture (State academy) "Eastern Medieval Architecture. The Building Traditions of Byzantium and Neibouring Lands (Oxford University Press, 2019). This part of the book of the scholar is devoted to the development of the Byzantine tradition in Russian postrenaissance architecture. The description of Robert Ousterhaut's scholarly biography and his impact to the study of the history of architecture was published in the previous issue of this magazine in the article of Dmitry Shvidkovsky "Ousterhaut and the Byzantium".

Summary: It is impossible to overestimate the role of professor Robert Ousterhaut in the studies of the history of Byzantine art. At the present day he is the leader in the world studies of the architecture of Byzantium, the real heir of the great Rihard Krauthaimer and Slobodan Curcic, whom he had left behind in his works. His books are known very well in Russia. In his study of Russian architecture of the Middle Ages, the author analyses the artistic image and the design characteristics of church architecture. The author highlights the distinctive features of the largest centres of Moscow, Novgorod, Pskov, Chernigov, and other cities. Much attention is paid to the influence of Italian architecture on the development of Russian church construction, which is associated with the participation of Italian architects in the construction of the main churches in Moscow. The outstanding cathedrals of the Moscow Kremlin - the Assumption, the Annunciation, and the Archangel Michael cathedrals, created with the participation of Italian architects, are considered in detail.

Russian history and Russian architecture take a very different course. Much of Russia was destabilized in the thirteenth century by the invasion of the Mongols, with the notable exceptions of Novgorod and Pskov, where medieval churches survive from the twelfth century onward. In Novgorod, churches like the St. Theodore Stratelates (1360) or the Church of the Transfiguration of the Savior on Elijah Street (1374) have simple nine-bayed plans, marked by pilasters on the façades, with steeply pitched roofs rising to a single dome (Fig. 1) ${ }^{1}$. Distinctive

1. For Russian architecture, see H. Faensen and V. Ivanov, Early Russian Architecture (London, 1975); Brumfield, A History
The author considers St. Basil's Cathedral, built by Ivan IV (the Terrible) in memory of his victory near Kazan in 1552, to be the most impressive building of this period. The church has a unique composition. It consists of nine adjoining chapels.

In his research, the author also highlights one of the unresolved issues in the development of Russian architecture - the appearance of a characteristic onion dome. One of the assumptions put forward by the author is that the domes reflect the shape of the canopy over the Tomb of Christ. The influence of Islamic forms introduced into Russian architecture after the triumphant victory of the Russian troops in the Battle of Kazan, which brought significant territories of Mongolia under Russian control, is the author's another hypothesis. The author cannot single out a priority version but rightly believes that whatever the initial meaning of domed forms in Russian architecture was, they quickly became popular and acquired their symbolism.

Keywords: Russian architecture, Eastern Medieval Architecture, history of architecture.

is the use of quadrant arches on the corner façade bays, as had been employed earlier at the Piatnitsa Church in Chernigov (see Fig. 12). In the Novgorod churches, the quadrant arches are multiplied to decorative effect. As with most of the late buildings in the area, both are roughly built, with plastered exteriors.

As Russia recovered from the Mongol invasions, Muscovy developed its own distinctive architecture, first seen perhaps in the cathedrals of Zvenigorod, near Moscow, dedicated to the Dormition (ca.

of Russian Architecture; augmented by the many insights in Shvidkovsky, Russian Architecture. 


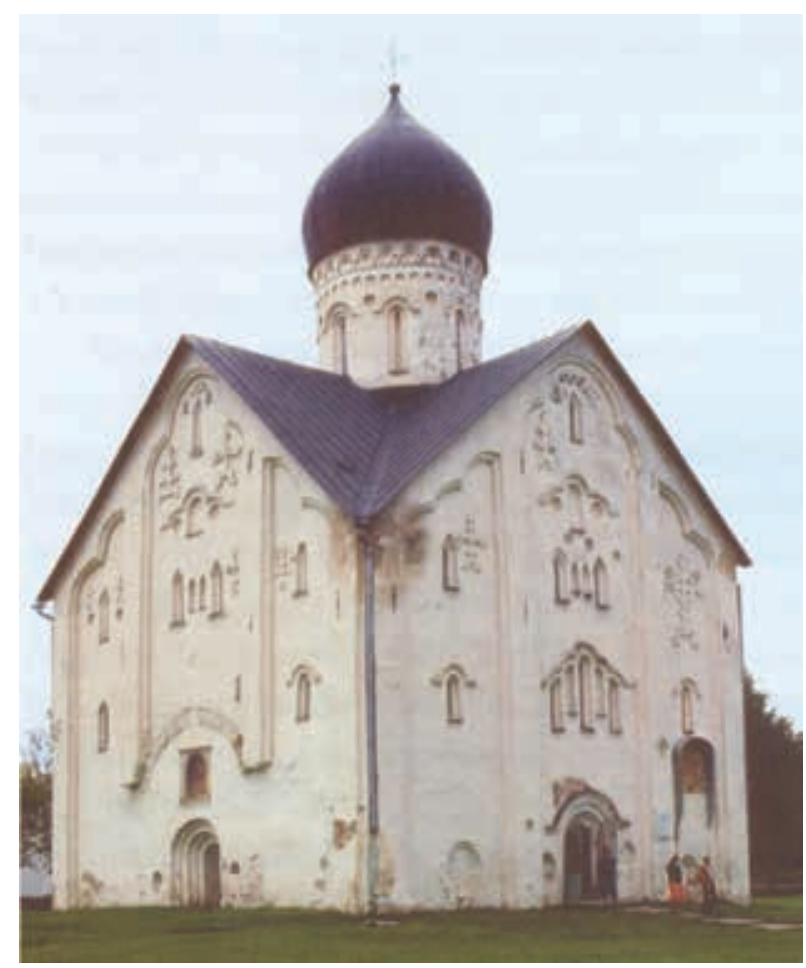

IIl. 1. Novgorod, Church of the Transfiguration of the Savior on Elijah Street, view from the southeast (author)

1396-98, now much altered) and the Nativity of the Virgin in the Storozhevsky Monastery of St. Savva (ca. 1405-8) (Fig. 2). [NB: Unlike Byzantium, where a single church per district or city had the rank of cathedral, in Russia, multiple churches within the same area could have this rank.] Both have simple, nine-bayed plans with a central dome- the standard plan through out Russia, ultimately derived from the Byzantine cross-in-square type. In many ways, the Zvenigorod churches (and, indeed, their nowlost counterparts in Moscow) hark back to the model of Vladimir from before the Mongol Conquest, with tall proportions and construction of white limestone. Façade bays are topped by decorative arches, or zakomary, rising above pilasters or colonnettes. Decorative bands of sculpture enliven the façades, and the portals have stepped jambs and archivolts, with ogival arches. The zakomary of the Dormition Church must have also had ogival arches, as are preserved at the Nativity Church. In addition to those of the façade, there is a second zone set diagonally above the corner bays and a third zone framing the dome drum. The decorative aspects of the zakomary are enhanced by a loosening relationship between interior and exterior, as the pilasters do not always correspond to the structural divisions of the interior. These details appear in the oldest surviving Moscow church, the Cathedral of the Savior in the

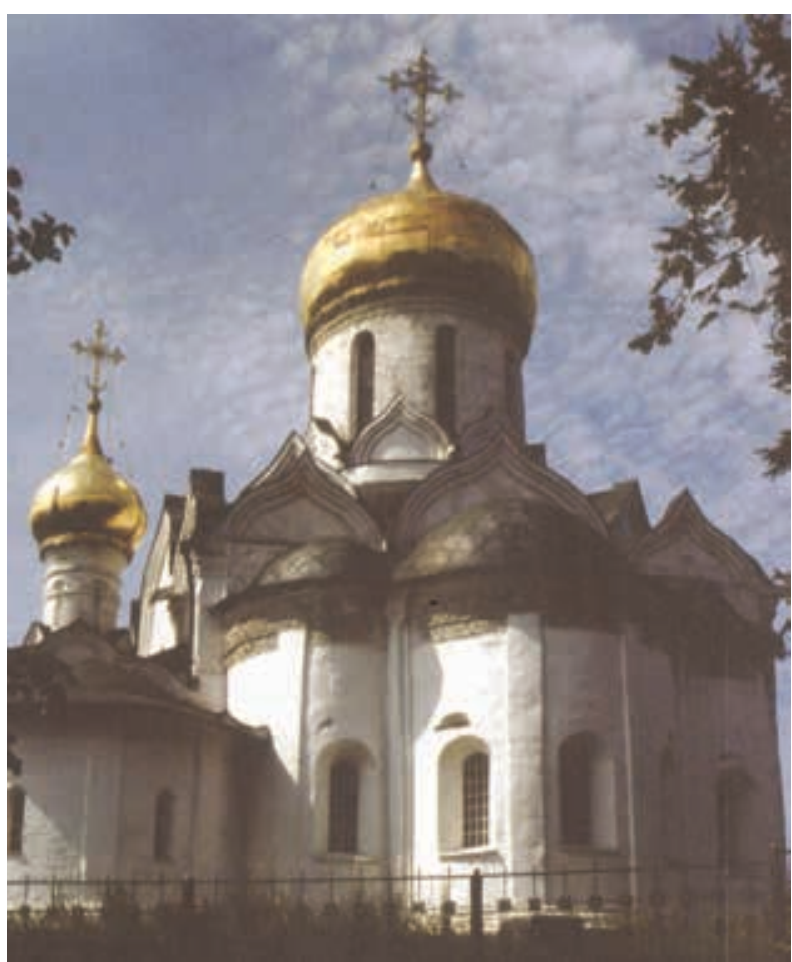

IIl. 2. Zvenigorod, Cathedral of the Nativity of the Virgin in the Storozhevsky Monastery of St. Savva (courtesy of Moscow Architectural Institute Scientific Library)

Andronikov Monastery, built in the 1420 s, which increases the complexity of the decorative arcading, as it steps up gradually to the base of the dome.

The beginnings of Moscow are usually traced to its first textual reference in 1147 , although the settlement must have been older. In 1156, a wooden fortress rose on the high ground at the confluence of the Moscow and smaller Neglinnaia Rivers, where the Kremlin now stands (Figs. 3 and 4). The name Kremlin means "citadel," but like the Acropolis in Athens, it became a site-specific toponym. Moscow's early history is marked by clashes with the Mongols and with feuding Russian principalities; for much

of its early history, it was little more than a trading outpost in the vast forests of Russia. By the fourteenth century, Moscow began to emerge as the central power, notably under Ivan I, who took control in 1325. In the same year, the patriarch Peter made Moscow his unofficial residence, thus marking the beginnings of the consolidation of church and state. The first stone church was built shortly thereafter, the Cathedral of the Dormition (subsequently rebuilt), significantly adopting the dedication of the Cathedral of Vladimir, the spiritual centre of Russia. Facing continued confrontations with the Mongols, the fortifications were rebuilt in limestone in 1367, more or less along the lines of the current triangu- 


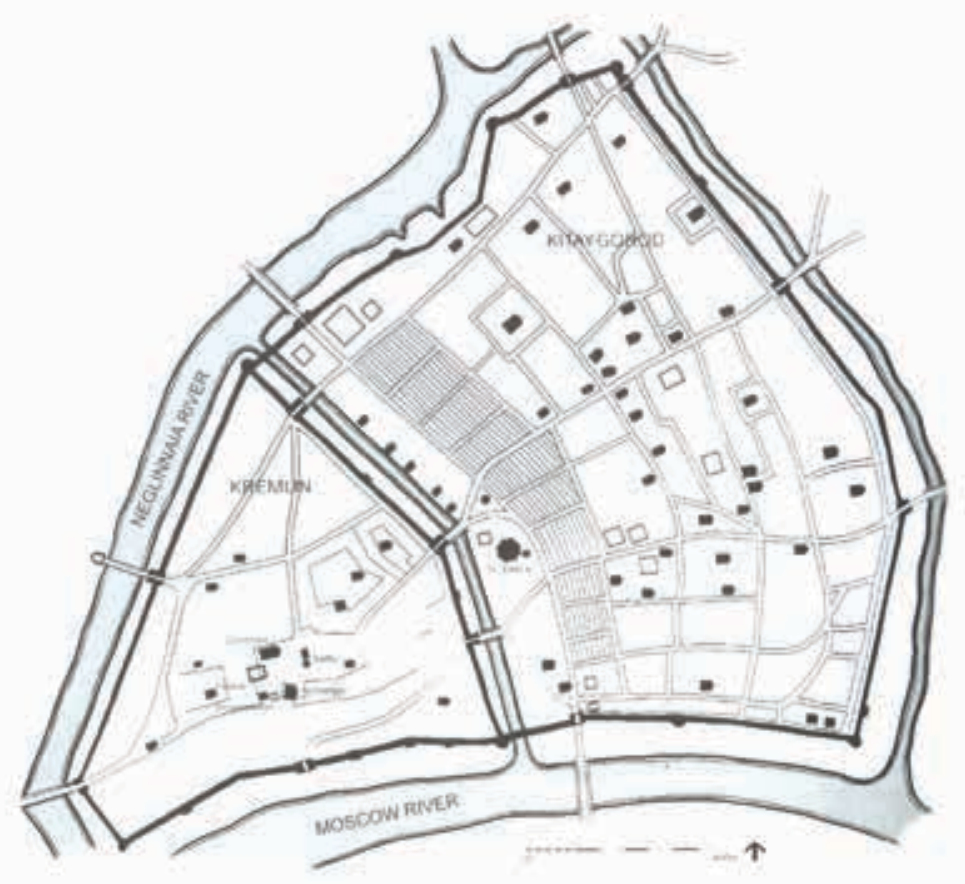

IIl. 3. Moscow, Historic plan of the Kremlin and Kitay-Gorod (author, after Moscow Institute of Architecture Scientific Collection)

lar enclosure, extending approximately 2 kilometres in length. Because traditional Russian architecture was ephemeral, built of wood and prone to fires, the appearance of the Kremlin and the city around it difficult to envision before the fifteenth century.

By the late fifteenth century, a new architectural impetus arrived from Italy, in the form of imported Italian architects. The period of Ivan III (r. 1462-1505) is particularly important, followed by that of his son, Vasili III (r. 1505-33). In 1472, Ivan married Zoe (renamed Sophia) Palaiologina, niece of the last Byzantine emperor and claimant to the Byzantine throne ${ }^{2}$. With the collapse of the Byzantine Empire, she had fled to the papal court in Rome, where she came under the protection of Cardinal Bessarion, who subsequently arranged her marriage to Ivan. Through Bessarion, Sophia was associated with the Greek and Italian intellectual circles of northern Italy and thus arrived in Moscow with both Italian Renaissance and Byzantine imperial baggage. Shortly thereafter, Italian architects appear prominently in the historical record ${ }^{3}$.

The first major project was the rebuilding of the Cathedral of the Dormition in the Kremlin, 1475-79, under the direction of Rodolfo Fioravanti, nicknamed Aristotele (Figs. 5-7). A reconstruction of the original church had been undertaken by Muscovite builders

2. A.-M. Talbot, "Sophia Palaiologina," Oxford Dictionary of Byzantium, $3^{\text {rd }}$ vol. (Oxford, 1991), 1928.

3. Shvidkovsky, Russian Architecture, 73-104. in 1472, but it collapsed two years later as it neared completion. Masons from Pskov were consulted, but they declined to take on the project, leading Ivan to seek outside expertise. The Bolognese architect Fioravanti was well known in Italy for his engineering skills, and he was a friend of the theorist Filarete. Once he arrived in Russia, he was taken to Vladimir to examine the Cathedral of the Dormition, which his project was intended to imitate and to surpass (see Figs. 8 and 9). He thus combined Romanesque details derived from Vladimir with a simplified twelve-bayed plan, topped by five domes. Fioravanti introduced a modular plan, so that all bays are the same dimensions, with groin vaults set at the same height covering the undomed bays, rising above cylindrical piers. To maintain the modular scheme, coupled chapels flanking the sanctuary were covered by a single dome, and to give it prominence, the central dome was increased in scale, with a diameter larger than the width of the bay it covers.

Rather than a separate narthex, the western three bays, all groin vaulted, are fully integrated into the modular design. On the façades, details are simplified; arcades are identical, the bays marked by pilasters, while the Romanesque forms of the portals and the corbel table frieze recall Vladimir. Fioravanti used a carefully cut limestone ashlar, the stones set with a strong mortar, while the vaulting was constructed of lightweight brick, reinforced with iron ties. 


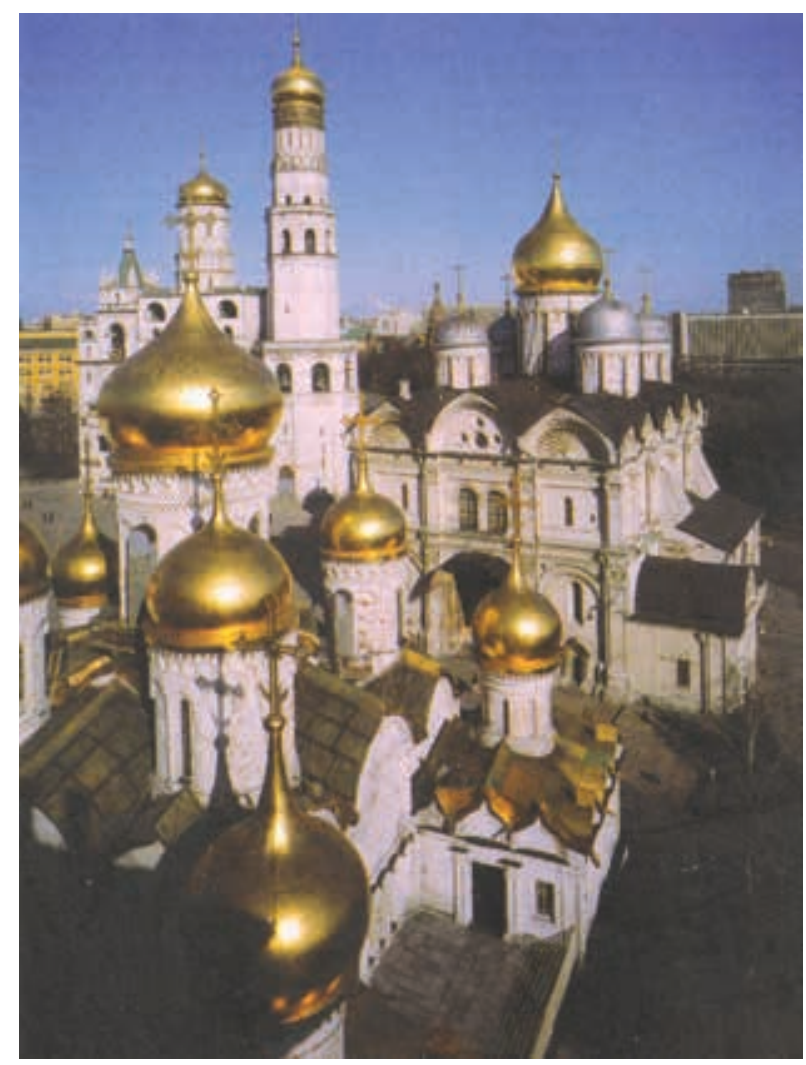

IIl. 4. Moscow, Kremlin, general view looking east, with the Cathedral of the Annunciation in the foreground and the Cathedral of the Archangels and the Bell Tower of Ivan the Great behind it (courtesy of Moscow Architectural Institute Scientific Library)

The lofty interior has the feel of a spacious hall, easily adaptable for imperial ceremony, as it became the coronation church. The gradual raising of the iconostasis in subsequent centuries now blocks the view into the eastern vaults, and although it blends seamlessly with the multiple registers of mural painting, the iconostasis alters the spatial configuration, so that the central dome no longer appears centrally but as the termination of the longitudinal axis of the naos, with the sanctuary invisible behind the screen. In short, the cathedral represents a traditional Russo-Byzantine architectural vocabulary reinterpreted by an Italian Renaissance architect.

Paralleling the introduction of Renaissance architectural ideas was the introduction of Byzantine court ceremonial and ideology. Both seem to have come with the entourage of Sophia Palaiologina. Ivan selected the offspring of Sophia as his heir, rather than the children of his first wife, thus insuring a Byzantine bloodline. Within a few decades, we begin to find references to Moscow as the "Third Rome" and the "Second Constantinople," as Russia assumed the role of political and spiritual successor to Byzantium as the bastion of Orthodoxy. With court ceremonial came court titles, and Ivan III be- gan to use the titles of tsar (derived from Caesar) and imperator (emperor).

Soon after the completion of the Dormition Cathedral, the nearby Cathedral of the Annunciation was rebuilt, 1484-89, to serve as the palace chapel (Figs. 8 and 9). Work was done by architects from Pskov, who had earlier declined to take on the challenge of rebuilding the Dormition Cathedral after its collapse. Their church was considerably smaller and simpler, essentially a nine-bayed church with pier supports, set atop a vaulted substructure to bring it to the level of the residential chambers in the adjoining palace, to the west. It was originally topped by three domes, with two small domes above the chapels flanking the sanctuary, its silhouette enhanced by superimposed gables (kokoshniki) with ogival arches. Through the next century it was expanded, with a covered terrace forming an ambulatory, surmounted by independent domed chapels on the gallery level (1562-64), with two new domes added above the western corners of the naos. In comparison to the Dormition Church, the interior is relatively cramped, limited by the famed iconostasis (painted by Theophanes the Greek, Prokhor of Gorodets, and Andrei Rublev), which closes off the sanctuary and flanking chapels. Despite its rank as cathedral, the church functioned as a private chapel for the devotions of members of the royal family. Stylistically quite distinct, the Annunciation Cathedral represents the continuation of traditional architectural forms, which parallel the Renaissance imports.

The cathedral of the Archangel Michael at the Kremlin, built ca. $1505-9$ by Alevisio Lamberti da Montagnana, a Venetian architect, continues the Renaissance trend begun by Fioravanti (see Fig. 4). The five-domed design follows that of the Dormition Cathedral, but smaller in scale. Its elegant exterior is classicizing, with Corinthian capitals to the pilasters and ornamental half-shells in the zakomary. Similarly, the Great Bell Tower of Ivan III was begun by a Milanese architect known as Bon Fryazin (1505-8), its lower portions resembling a Lombard-style, freestanding campanile although it was subsequently heightened and expanded to house twenty-one bells (see Fig. 4).

Beginning in 1485, the Kremlin was strengthened with new walls of red brick, following the line of the older stone walls, punctuated with projecting towers (Fig. 10). The work is credited to a mixed team of Russian and imported Italian builders, with the latter directing the construction of the towers. With fortification of the residential neighbourhood Kitay-Gorod 


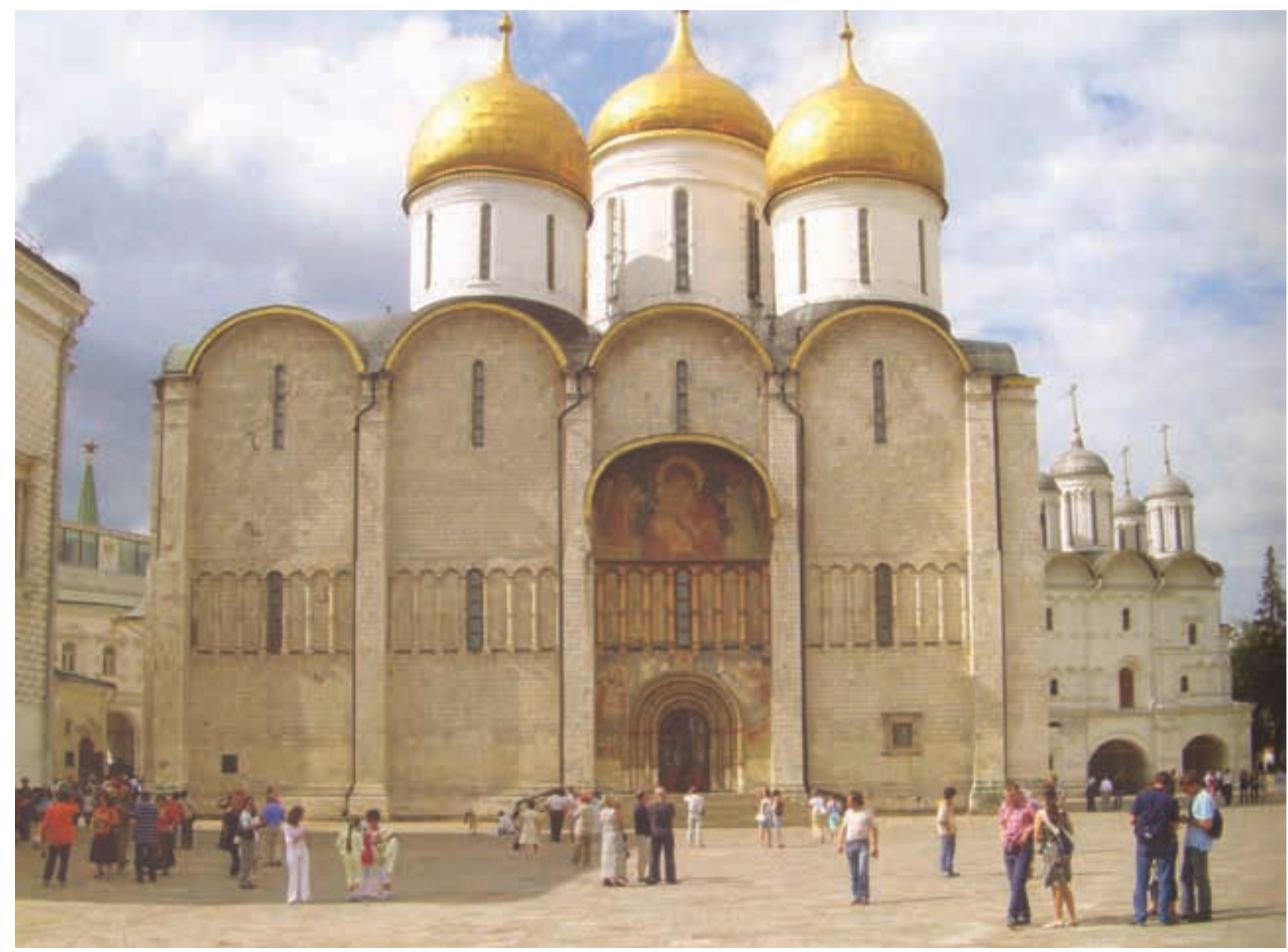

IIl. 5. Moscow, Kremlin, Cathedral of the Assumption, view from the south (author)

to the east, 1536-39, the layout of Moscow began to resemble that of Smederevo in Serbia, with the citadel at the strategic point of a large triangular enclosure, separated internally from the residential area by a moat (see Fig. 3). At the same time, the towers reflect contemporary developments in Italian Renaissance- specifically Lombard-architecture. If we discount the later decorative extensions, the walls of the Kremlin would not look out of place in Milan.

At Kolomenskoe, once an imperial estate overlooking the Moscow River, several churches are preserved, the most important of which is the Church of the Ascension, built after 1528 to commemorate the birth of Ivan IV and dedicated in 1532 (Fig. 11). The plan is without precedent: a square naos expanded with cruciform arms, set on an elevated platform. As the church rises, the upper stage is octagonal, covered by a pyramidal tent roof, all constructed in brick. Kokoshniki appear at the transition to octagon, with zakomary at the base of the steeply pitched roof. The tent roof, or chatior, seen for the first time here, became a prominent feature in the architecture of the period of Ivan, but its origins are obscure. One theory is that the chatior developed out of indige- nous wooden architecture, although no examples are preserved from this early period (compare Fig. 12) ${ }^{4}$. Following this line of thought, the new architectural forms represented by Kolomenskoe stand in sharp contrast to the Italian-built cathedrals of the Kremlin and could thus mark a conservative, nationalistic backlash against the foreign influences.

Recent scholarship has emphasized the Italian Renaissance (and even some Gothic) details of the Church of the Ascension, however, and documentary evidence now indicates that an Italian architect, Pietro Annibale, known in Russian as Petrok Maly, was responsible for its design- the same architect who had directed the construction of the walls of Kitay-Gorod ${ }^{5}$. It clearly demanded a skilled engineer to create the 62-meter-tall building, which required foundations 9 meters deep. All the same, the architect was certainly aware of the visual impact of traditional Russian forms, as the application of kokoshniki and zakomary attests. Should the chatior fall into the same category? Whatever the case, it would appear that an Italian architect was respon-

4. Faensen and Ivanov, Early Russian Architecture, 437-39.

5. Shvidkovsky, Russian Architecture, 111-21. 


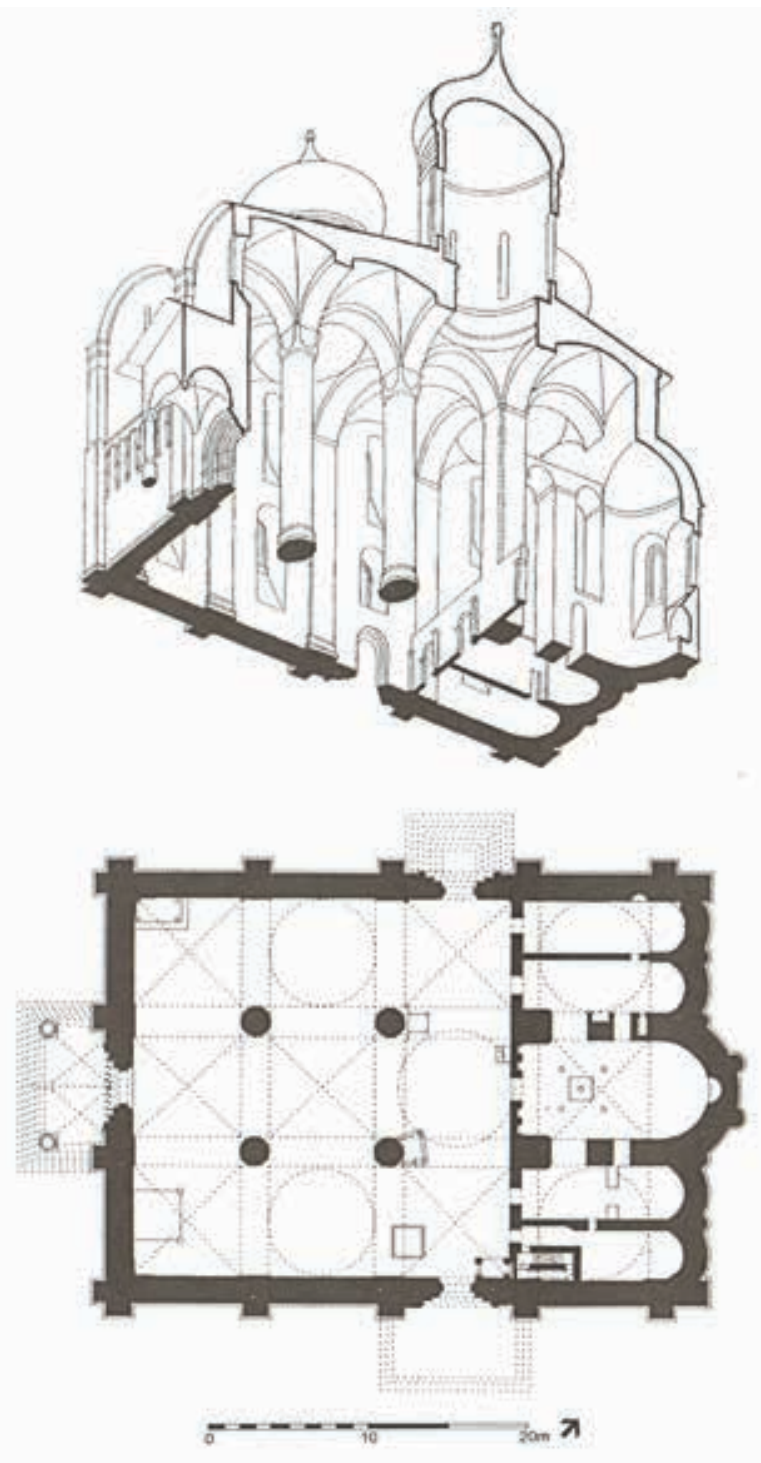

IIl. 6. Moscow, Kremlin, Cathedral of the Assumption, plan and isometric section (redrawn After D. Shvidkovsky, Russian Architecture and the West, 2007)

sible for the introduction of the distinctive form in masonry- one that has come to be interpreted as an indigenous Russian form.

The most iconic of the Moscow churches is also the most unusual. The Cathedral of St. Basil was built by Ivan IV (the Terrible) to commemorate his 1552 victory at Kazan - a critical event in Russian history; the church was completed in 1561 (Fig. 13) ${ }^{6}$. It was originally dedicated to the Intercession of the Virgin, but it gradually became associated with Basil the Blessed, a holy fool whose burial chapel was added at the end of the sixteenth century. The original church actually consisted of nine adjoining chapels raised on an elevated platform. Eight chapels around the perimeter rise to different heights and are topped

6. Shvidkovsky, Russian Architecture, 126-40.

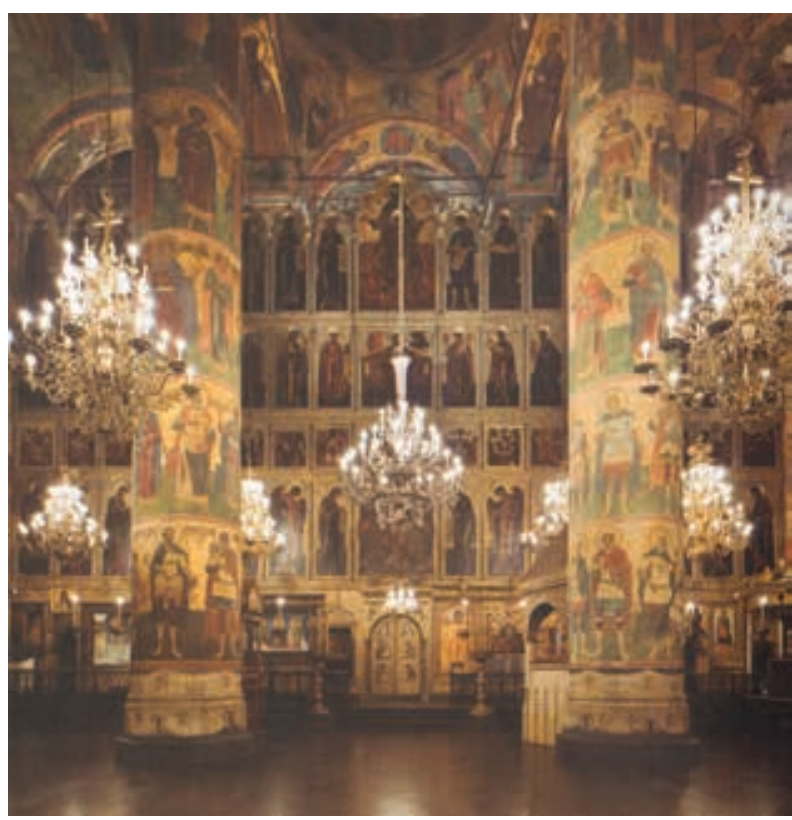

IIl. 7. Moscow, Kremlin, Cathedral of the Assumption, interior, looking east (courtesy of Moscow Architectural Institute Scientific Library)

by picturesquely distinctive onion domes. The central chapel - that of the Virgin - towers above the rest and is covered by a pyramidal tent roof, crowned by a tiny, gilded onion dome. The interior spaces are tall and tower-like, with maximum visual effect devoted to the exterior. The onion domes are in fact hollow, formed by metal sheathing over an armature; on the interior, the chapels terminate in rather modest cloister vaults.

In many ways, St. Basil's resembles a stage set, and it appropriately became the backdrop for the civic and religious ceremonies through which Moscow symbolically expressed its identity. The main western chapel was dedicated to the Entry of Christ into Jerusalem, and this became the focus of a special ceremony on Palm Sunday: conducted by the tzar, the patriarch rode a donkey at the head of a procession that ceremonially recreated Christ's entry into Jerusalem. Through such ceremonies, the church-and subsequently Moscow- became associated with Jerusalem.

One of the lingering questions in the development of Russian architecture is the appearance of the distinctive onion dome: does it have a special meaning or function? Most of the churches just discussed were constructed without them, only to have them added in later remodelings. Those at St Basil's are obviously integral to its inception.

One suggestion is they are functional, diverting snowfall from the roof. Another hypothesis is they reflect the form of the canopy above the Tomb of Christ in the Holy Sepulchre. Perhaps the most 


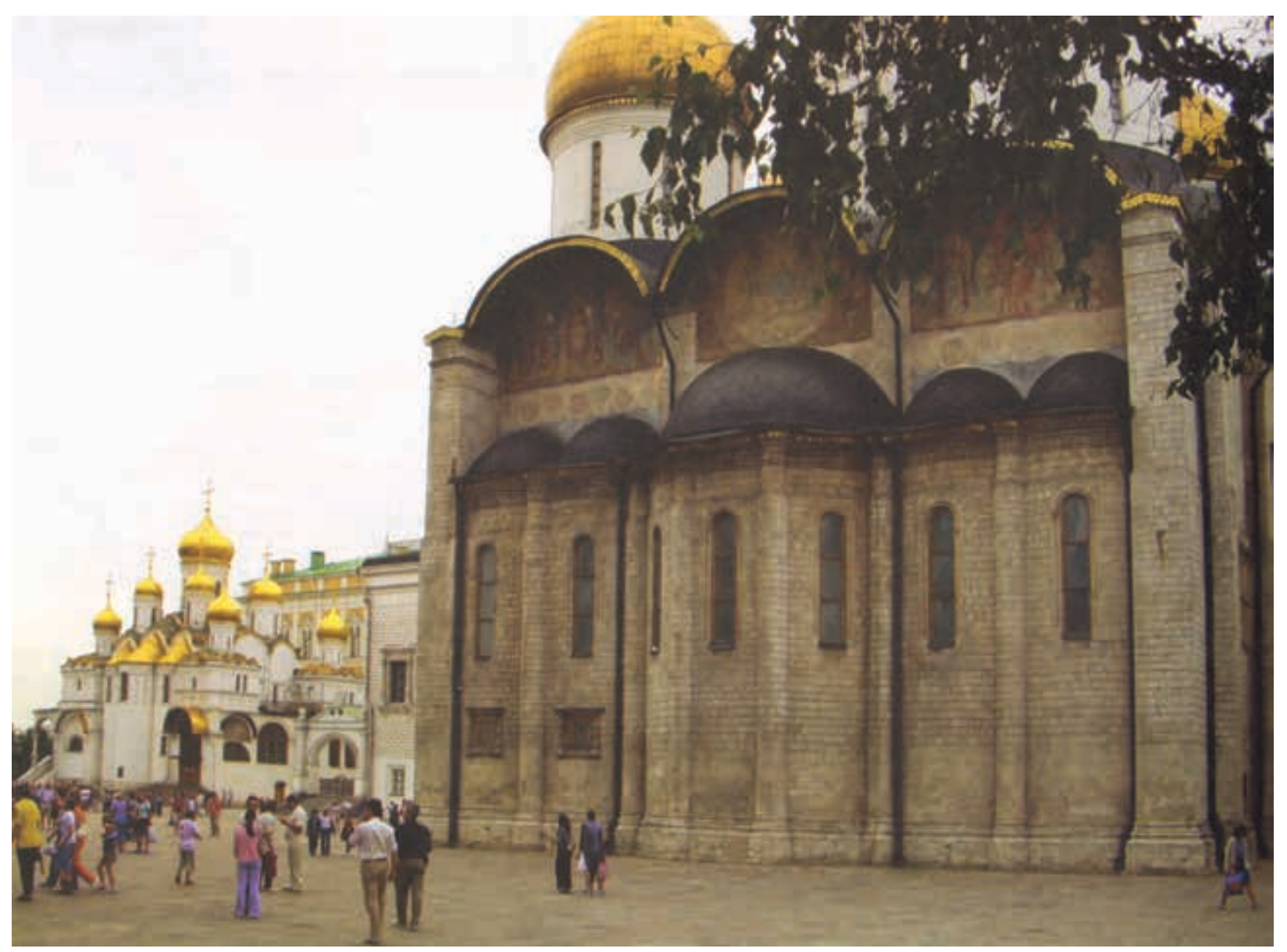

IIl. 8. Moscow, Kremlin, Cathedral of the Assumption, east façade, with the Cathedral of the Annunciation in the distance (author)

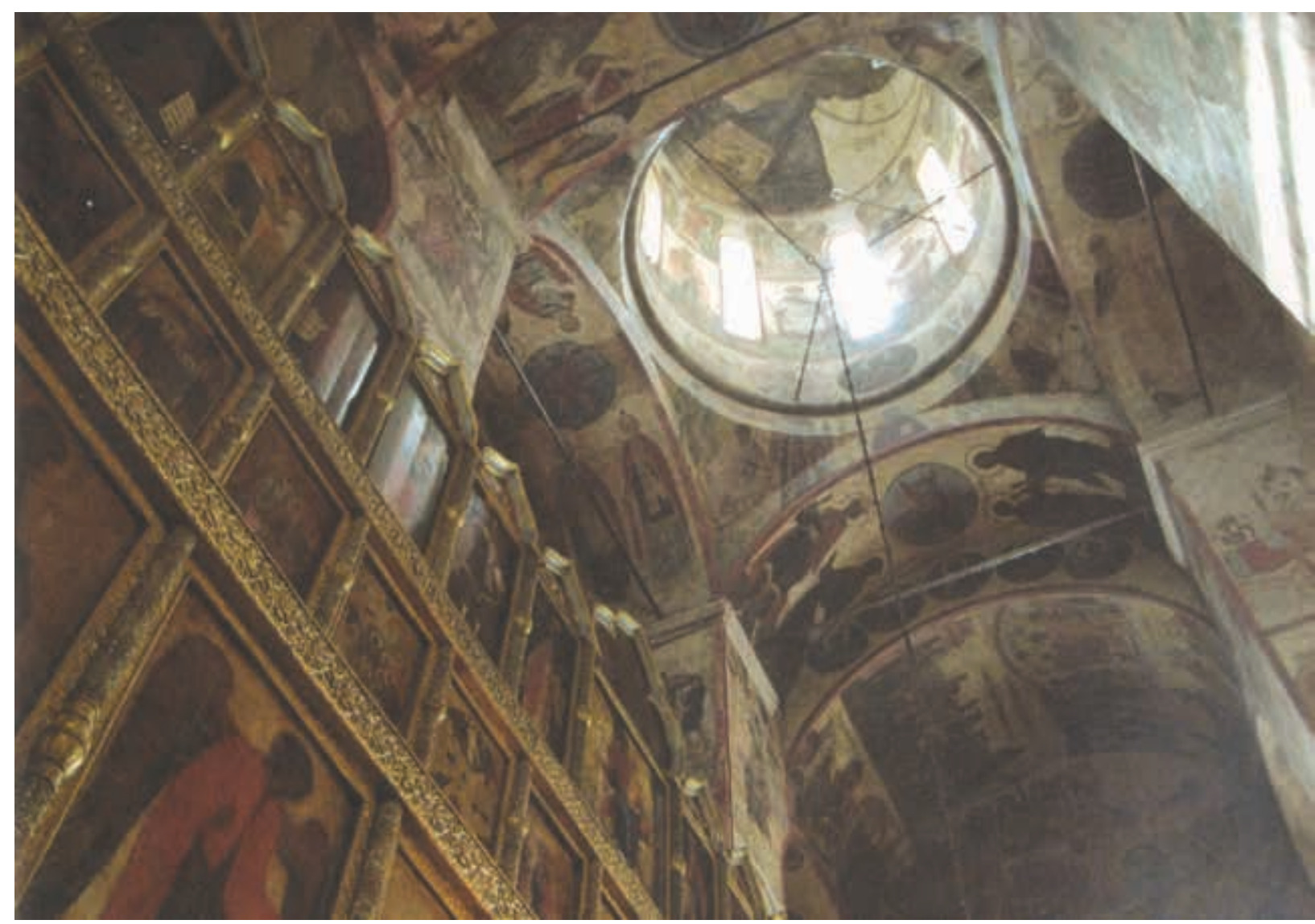

IIl. 9. Moscow, Kremlin, Cathedral of the Annunciation, interior, looking southeast toward the iconostasis (Shakko, Wikimedia Commons) 


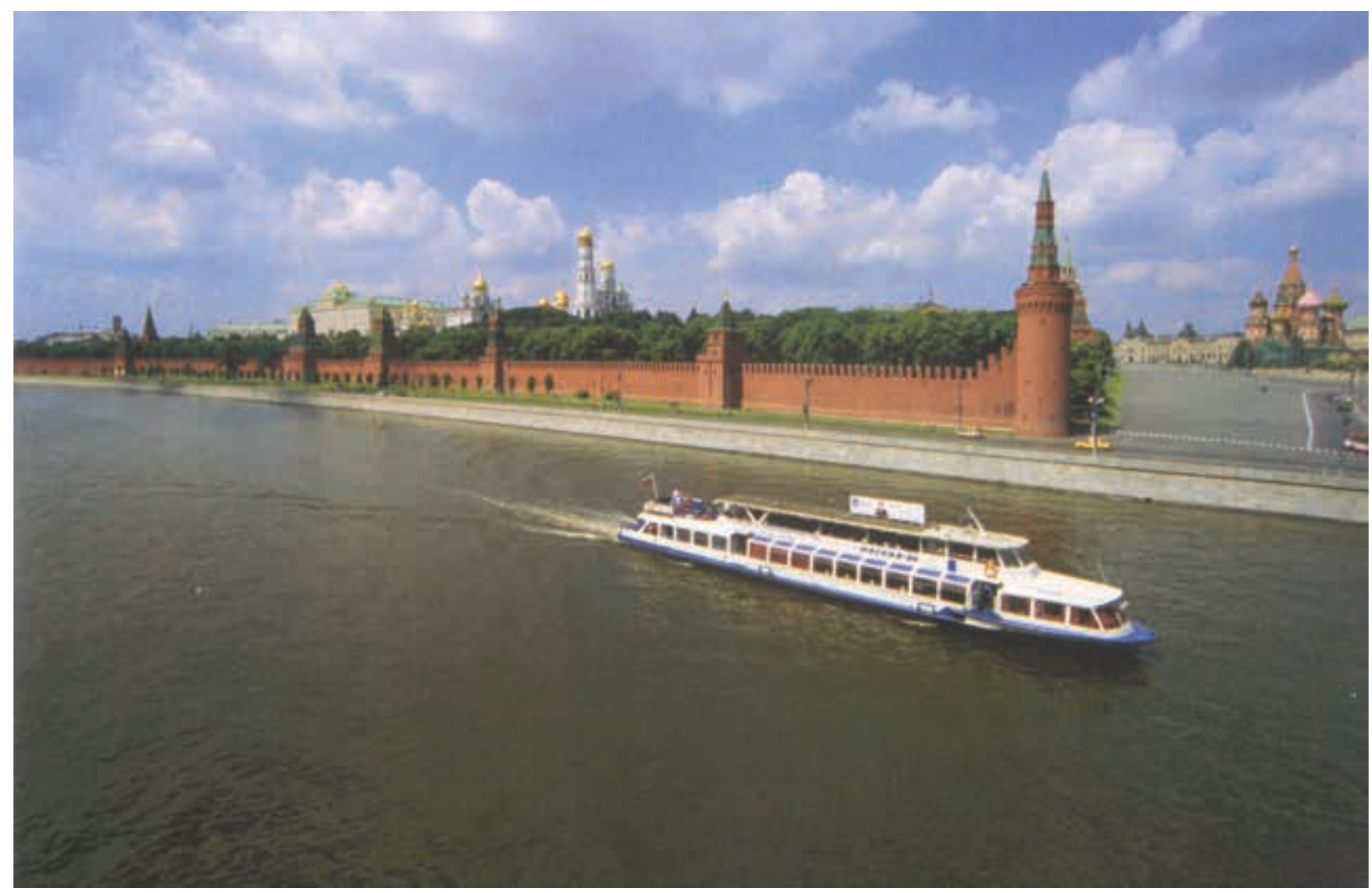

Ill. 10. Moscow, Kremlin, view of the fortifications from the Moscow River (Gerald Carr)

compelling suggestion is an indebtedness to Islamic forms, adopted as a triumphalist motif after the Battle of Kazan, which brought significant Mongol territory under Russian control ${ }^{7}$. Whatever their original meaning, they quickly became popular and took on a symbolism of their own, their shape compared to the flame of a candle, as a beacon of Orthodoxy.

Not all churches in Moscow resemble St. Basil's. The Renaissance rethinking of Byzantine forms at the Dormition Cathedral found a notable following, as, for example, at the Cathedral of the Dormition in the monastery of the Trinity and St. Sergius at Zagorsk (1559-85), which copies its namesake almost exactly, including the modular,

twelve-bayed plan, with five domes and five apses. Built under Ivan IV, the repetition of forms was intended to represent the power and royal associations of the monastery. Constructed almost simultaneously with St. Basil's and by the same patron, the church reflects the stylistic diversity possible in Russian architecture. Another stylistic alternative is provided by the Donskoy Monastery, founded in 1591 on the site where the future tzar Boris Godunov repelled a Tatar attack, aided by the miraculous icon

7. Shvidkovsky, Russian Architecture, 128, with additional notes to works (in Russian) by Brunov, Ilyin, Batalov, Vyachanina, and Bondarenko. of the Virgin of the Don (Fig. 14). The Old Cathedral, constructed in 1591-93, is relatively simple in plan, but its roof is composed of a series of zakomary, organized pyramidally to culminate in an onion dome raised above a tall drum. As in many examples, the dramatic exterior impression contrasts with a relatively conservative interior.

Russia's debt to the Mediterranean past is also evident in the Monastery of the New Jerusalem at Istra, near Moscow, begun in 1656 by Patriarch Nikon (Fig. 15) ${ }^{8}$. A scale copy of the Church of the Holy Sepulchre in Jerusalem, translated into a picturesque Russian vernacular, it appears considerably more spectacular than its prototype. At the same time, the monastery is painstakingly accurate in following the Jerusalem building, based on plans and models. Built to the same scale in plan as the original, it rose considerably taller, with a great conical vault towering above the Rotunda, over 60 meters high. Criticized in his day for his presumption, Nikon's contemporaries viewed his building more as a hijacking of the sacred than as a conceptualization of it.

8. Shvidkovsky, Russian Architecture, 169-73; R. G. Ousterhout "Building the New Jerusalem," in Jerozolima w kulturze europejskiy, eds. P. Paszkiewicza and T. Zadroznego (Warsaw, 1997), 143-54. 


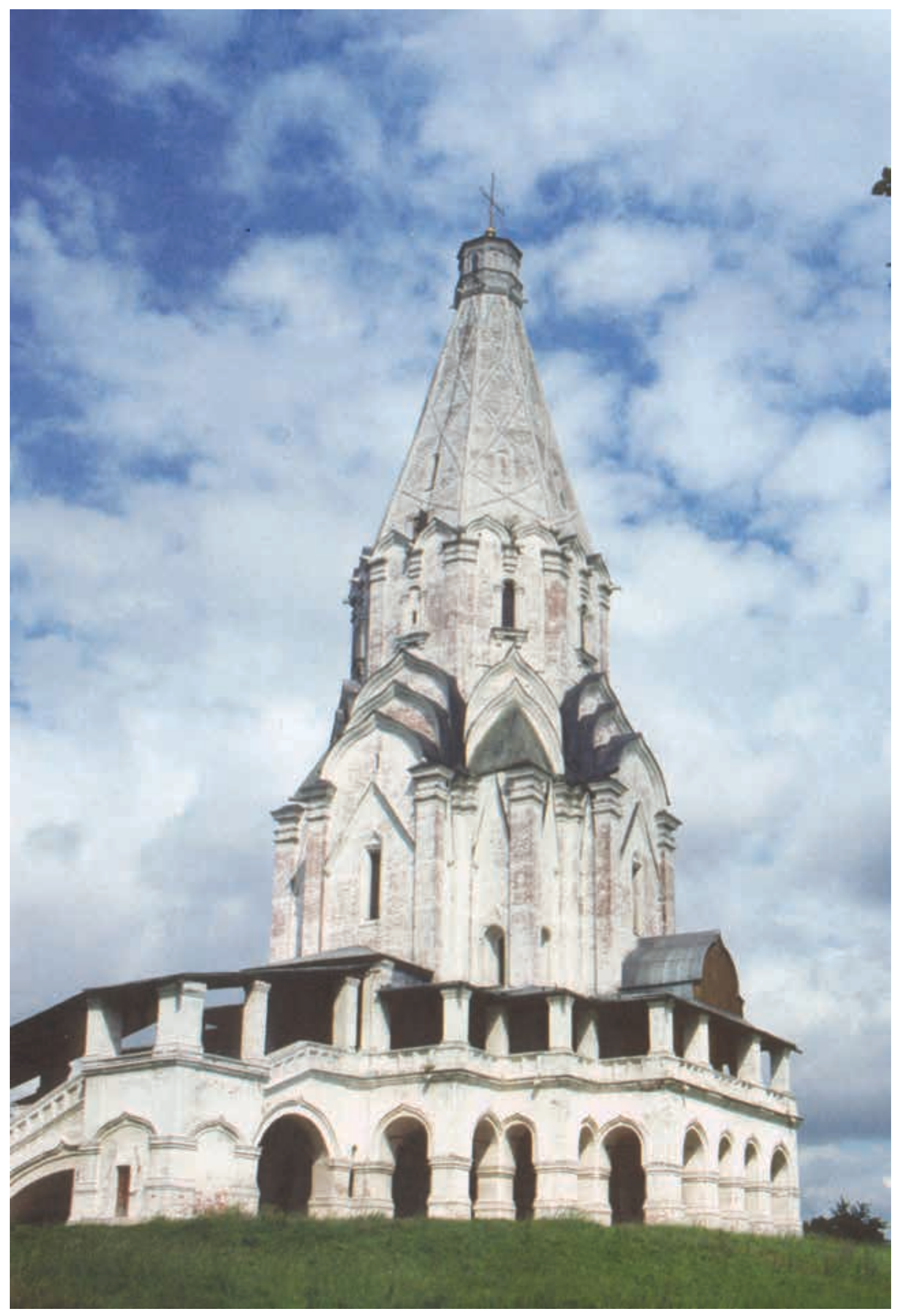

IIl. 11. Kolomenskoe, Church of the Ascension, view from the north (author) 


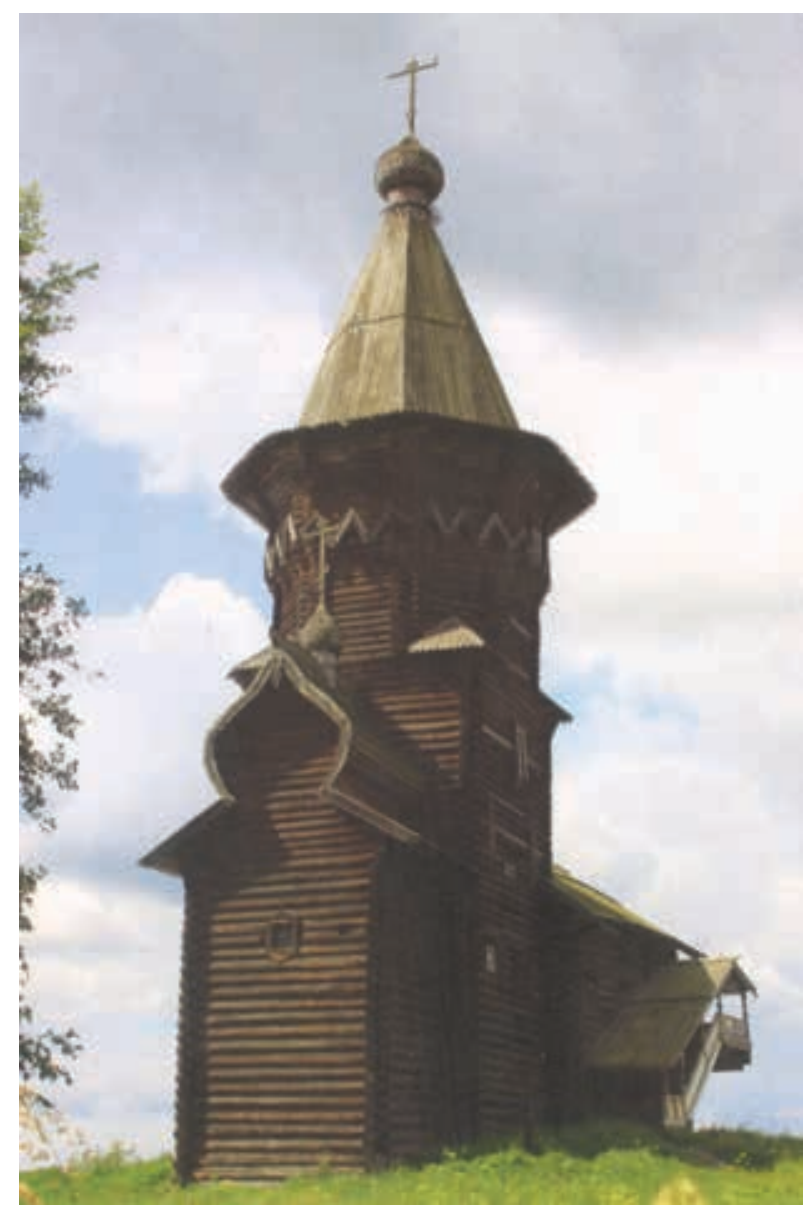

IIl. 12. Kondopoga, Church of the Assumption, dated 1774 (Happykg, Wikimedia Commons)

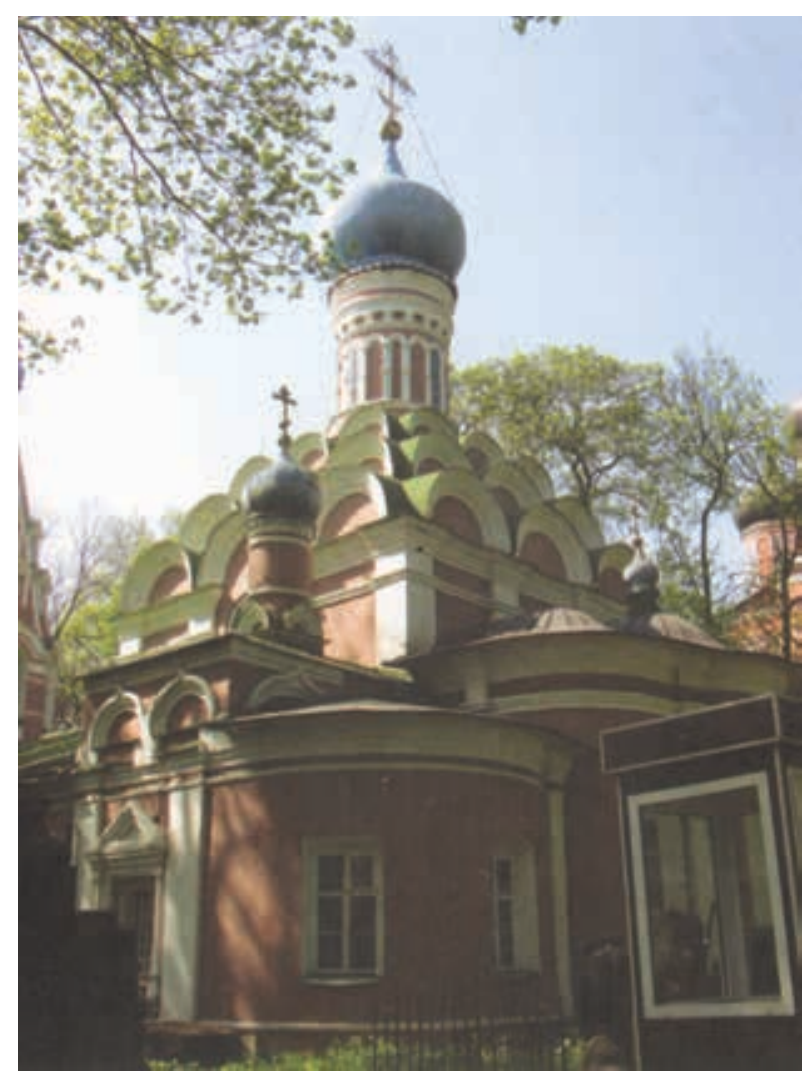

Ill. 14. Moscow, Donskoy Monastery, Old Cathedral, view (author)

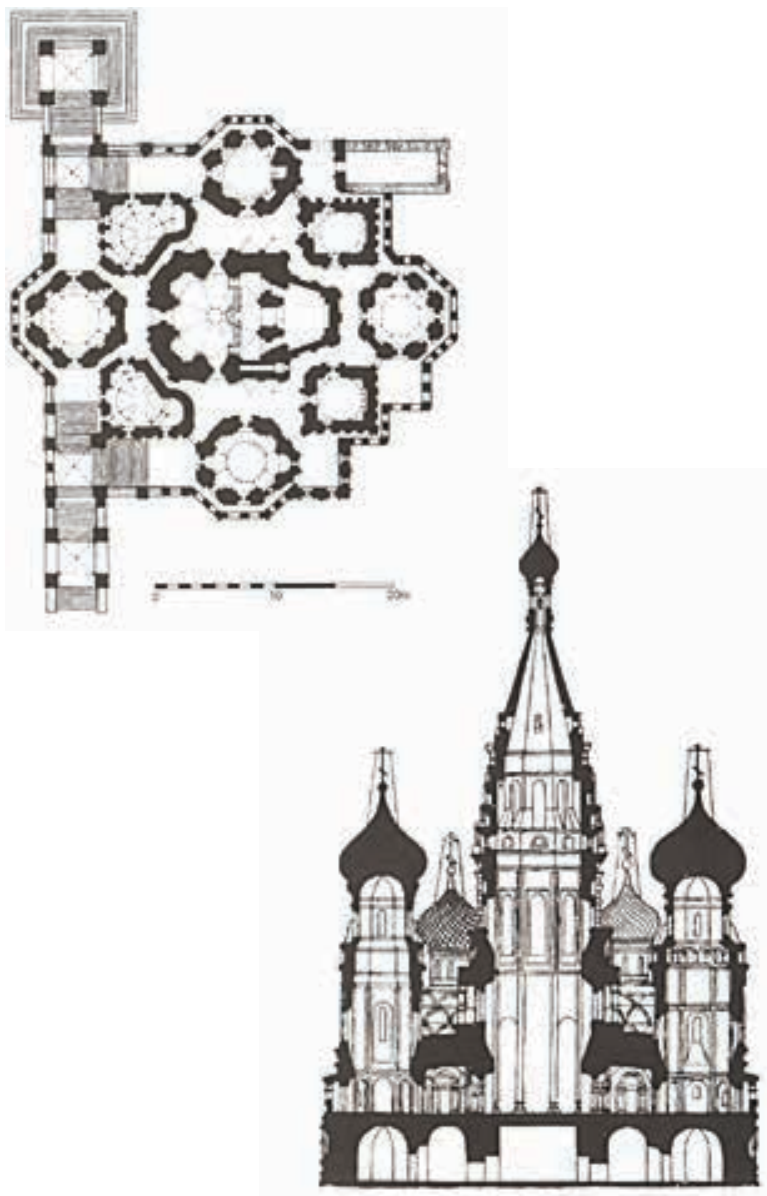

III. 13. Moscow, Cathedral of St. Basil the Blessed (Virgin of the Intercession), plan and transverse section (after H. Faensen and V. Ivanov, Early Russian Architecture, 1975)
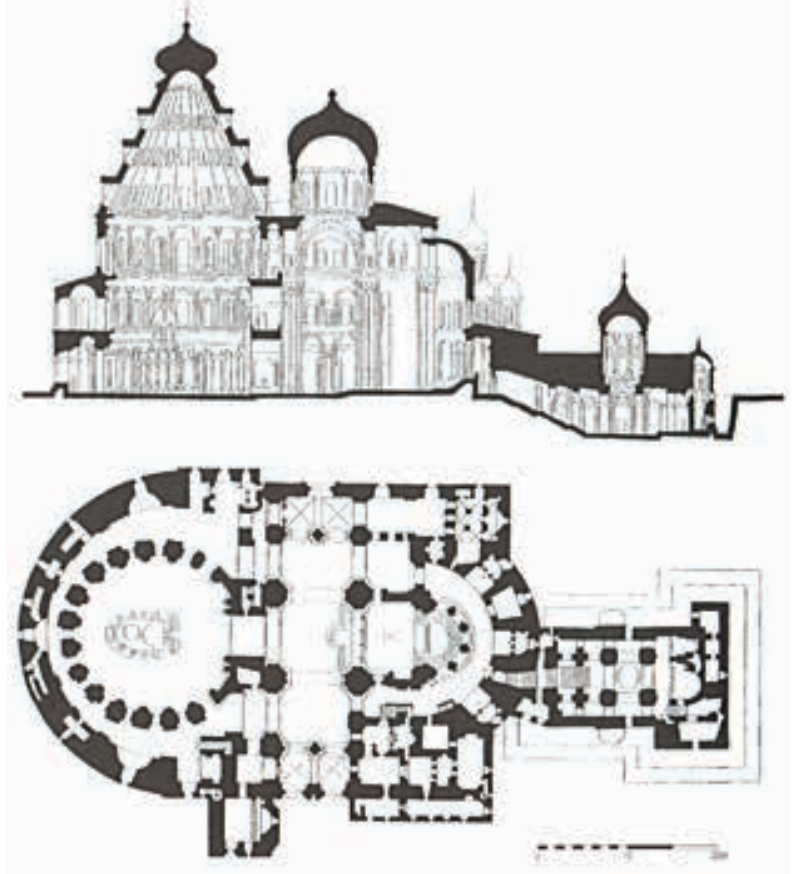

III. 15. Istra, Monastery of the New Jerusalem, Cathedral of the Resurrection, plan and section (after H. Faensen and V. Ivanov, Early Russian Architecture, 1975) 


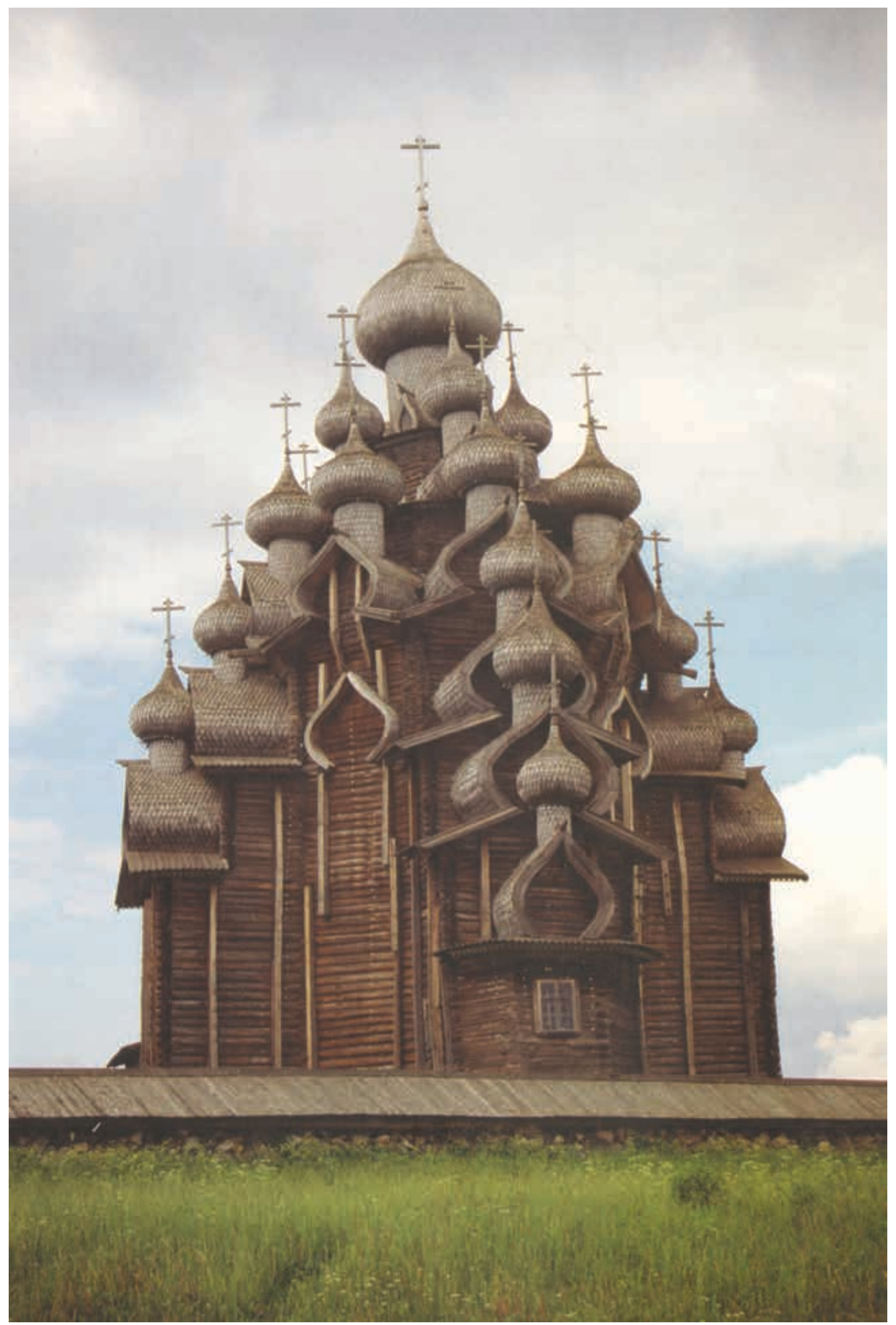

IIl. 16. Lake Onega, Kizhi Island, Church of the Transfiguration, view from the south (J. Stubbs, courtesy World Monuments Fund) 


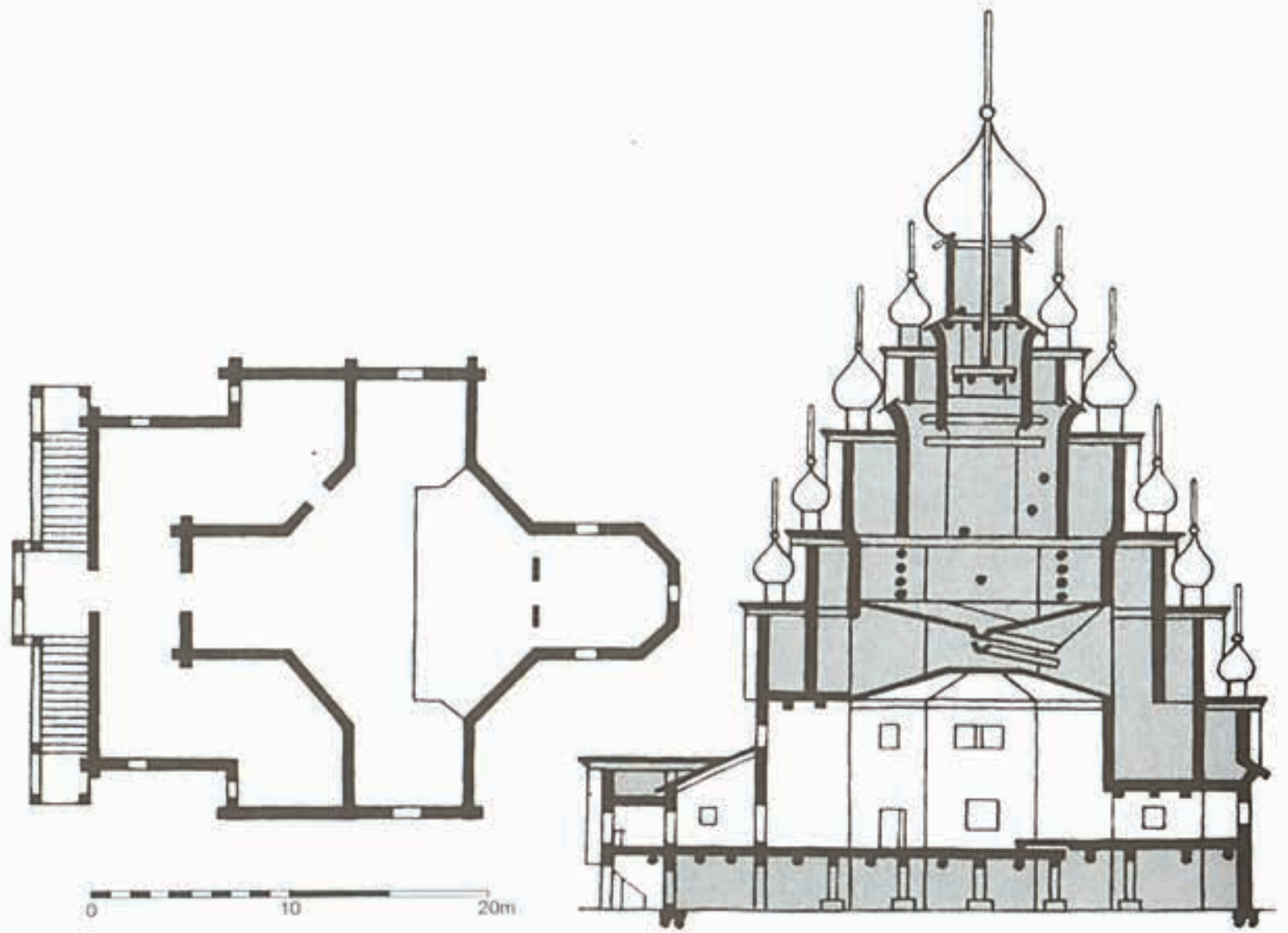

IIl. 17. Lake Onega, Kizhi Island, Church of the Transfiguration, plan and section (after H. Faensen and V. Ivanov, Early Russian Architecture, 1975, with the authors modifications)

With the majority of the Russian churches, the exterior was elaborated while the interior remained relatively simple, as necessitated by Orthodox ritual. An extreme example of this tendency may be seen in the Church of the Transfiguration on Kizhi Island (Lake Onega), built in 1714 and one of the oldest surviving wooden churches (Figs. 16 and 17) ${ }^{9}$. Here the exterior is dominated by the repetition of domes and kokohsniki, all of wood and roofed with shingles. While indicative of the preoccupation with decorative forms, the connection with the interior has been completely lost: the twenty-two domes are simply attachments to the superstructure. The interior is a simple octagon extended with cross arms, covered by a flat ceiling, barely one third the total height, with the sanctuary visually blocked by an iconostasis that extends to the ceiling. In short, the church represents a complete departure from the original Byzantine concept: at the core is the dome, whose meaning as a signifier of sacred space might be similar, but its formal and architectural significance has been lost.

9. Faensen and Ivanov, Early Russian Architecture, 505-11.

\section{REFERENCES}

1. Callmer, J. 1987, "The Archaeology of Kiev to the End of the Earliest Urban Phase", Harvard Ukranian Studies II, pp. 323-64. (in English)

2. Komech, A. I. 1995. Drevnerusskoe zodchestvo konca Xnachala XI v., Moscow.

3. Ioannissian, O., Ivakin, G. 2009. "Desjatinnaja cerkov' v Kieve: 'staryi vzgljad' v novom osveshhenii", Archeologia Abrabamica, Moscow, pp. 179-202. (in Ukrainian)
4. Ivakin, G., Ioannissian, O. \& Jolshin, D. 2013. "Arhitekturno-arheologichni doslidzhennjacerkvi Bogorodici Desjatinnoiv Kievi u 2008-2011." Slovjani I Rus': arheologija ta istorija, pp. 73-80.

5. Shvidkovsky, D. O. 2007. Russian Architecture and the West (New Hüvca 2007) (in English) 


\section{ВОСТОЧНАЯ СРЕДНЕВЕКОВАЯ АРХИТЕКТУРА. РОССИЯ}

В этом номере журнала публикуется продолжение перевода новой книги выдающегося историка архитектуры Византии профессора Пенн юниверсити (США) и почетного профессора Московского архитектурного института (Государственной академии) Роберта Остерхаута «Архитектура Восточного Средневековья. Строительные традиции Византии и близлежащих земель» (Оксфорд Юниверсити Пресс, 2019). Данная часть книги ученого посвящена развитию византийской традиции в русской постренессансной архитектуре. Описание научной биографии Роберта Остерхаута и его вклада в изучение истории зодчества было приведено в опубликованной в предыдущем номере нашего журнала в статье Дмитрия Швидковского «Византия и Остерхаут».

Аннотация. Невозможно переоценить роль профессора Роберта Остерхаута в изучении истории Византийского искусства. Он, безусловно, является сегодня лидером исследований архитектуры Византии в современной мировой науке, подлинным наследником великих Ричарда Краутхаймераи Слободана Чурчича, которых он превзошел в своих исследованиях. Его труды очень хорошо известны в России.

В своём исследовании русской архитектуры средних веков автор анализирует не только художественный образ, но и конструктивные особенности храмового зодчества. Автор выделяет отличительные особенности наиболее крупных центров Москвы, Новгорода, Пскова, Чернигова и др. Большое внимание в статье уделено влияниям итальянской архитектуры на развитие русского храмового строительства, что связано с участием итальянских архитекторов в возведении главных храмов Москвы. Особенно подробно рассмотрены выдающиеся соборы Московского Кремля - Успенский, Благовещенский, Архангела Михаила, созданные при участии итальянских архитекторов.

Русская история и русская архитектура стали развиваться по другому направлению. В XIII веке большая часть Руси, за исключением Новгорода и Пскова, где средневековые церкви сохранились с XII века, была дестабилизирована из-за вторжения монголов. Церкви в Новгороде подобные церкви Феодора Стратилата (1360 г.) или церкви Спаса Преображения на Ильине улице (1374 г.)
Наиболее выдающимся сооружением этого периода автор считает Собор Василия Блаженного, который был построен Иваном IV (Грозным) в память о его победе под Казанью в 1552 году. Храм отличается уникальной композицией. Его составляют девяти примыкающих друг к другу часовен.

В своём исследовании автор также освещает один из нерешенных вопросов развития русской архитектуры появление характерного луковичного купола. Одно из предположений, выдвинутых автором - купола отражают форму навеса над Гробом Христа. Другая гипотеза автора - влияние исламских форм, привнесенных в русскую архитектуру после триумфальной победы русских войск в Казанской битве, которая принесла значительные территории Монголии под контроль России. Автор не может выделить приоритетную версию, но справедливо считает, что каким бы ни было первоначальное значение купольных форм в русской архитектуре, они быстро стали популярными и приобрели собственную символику.

Ключевые слова: Русская архитектура, Восточная средневековая архитектура, история архитектуры.

имеют простые девятичастные планы с лопатками на фасадах и крутыми скатными крышами, восходящими к единой главе. (рис. 1) ${ }^{1}$. Отличительной особенностью является использование

1. По русской архитектуре см. H. Faensen and V. Ivanov, Early Russian Architecture (Лондон, 1975); Brumfield, A History of Russian Architecture; дополнения Shvidkovsky, Russian Architecture. 
лучковых арок на боковых частях фасада, как это было ранее сделано в Пятницкой церкви в Чернигове (см. рис. 12). В новгородских церквях количество лучковых арок увеличено для большего декоративного эффекта. Как и большинство поздних построек в этих местах, они построены в грубоватой манере, фасады оштукатурены.

По мере того, как Русь оправлялась от монгольских нашествий, в Московии образовалась собственная самобытная архитектура, которую впервые можно заметить в соборах Звенигорода под Москвой, посвященных Успению (ок. 13961398 гг., в настоящее время значительно изменен) и Рождеству Богородицы в Саввино-Сторожевском монастыре (ок. 1405-8) (рис. 2). [Примечание: в отличие от Византии, где только одна церковь в районе или городе имела значение собора, в России этот ранг могли иметь несколько церквей в одном районе.] Обе церкви имеют простые девятичастные планы с центральным куполом. Это обычный тип плана соборов, применявшийся по всей Руси, заимствованный из Византийской крестово-купольной системы. Во многих отношениях звенигородские церкви (и их ныне утерянные аналоги в Москве) восходят к моделям церквей во Владимире до монгольского завоевания с вытянутыми вверх пропорциями, построенные из белого известняка. Декоративные арки - закомары, возвышающиеся над пилястрами или аркатурно-колончатыми поясами, венчают фасадные пролеты. Декоративные скульптурные пояса оживляют фасады, порталы имеют ступенчатое обрамление и архивольты со стрельчатыми арками. Закомары Успенской церкви должно быть тоже имели стрельчатые арки, такие же, как те, которые сохранились на Рождественской церкви. В дополнение к тем закомарам, что на фасаде, имеется второй ярус, расположенный по диагонали над углами, и третий ярус, обрамляющий барабан купола. Декоративность закомар усиливается ослаблением взаимоотношений между интерьером и экстерьером, поскольку пилястры не всегда соответствуют структурным частям интерьера. Эти детали, использованные в старейшем сохранившемся московском храме - Спасском соборе Андроникова монастыря, построенном в 1420-х годах, увеличивают сложность пояса декоративных арок, постепенно поднимающегося к основанию купола.

Начало истории Москвы обычно относят к её первому упоминанию в текстах 1147 года, хотя поселение должно быть образовалось гораздо раньше. В 1156 году деревянная крепость стояла на возвышенности у слияния Москвы и меньшей реки Неглинной, где сейчас стоит Кремль (рис. 3 и 4). Название Кремль означает «цитадель», но, как и Акрополь в Афинах, оно стало топонимом конкретной местности. Ранняя история Москвы характеризуется столкновениями с монголами и враждующими русскими княжествами. В начале своей истории Москва была немногим больше, чем торговым форпостом в обширных лесах Руси. K XIV веку город становится важным центром, особенно при Иване I, который пришёл к власти в 1325 году. В этом же году патриарх Петр выбрал Москву в качестве своей неофициальной резиденции, что положило начало консолидации церкви и государства. Вскоре после этого был построен первый каменный храм - Успенский собор (впоследствии перестроенный), который унаследовал значение Владимирского собора как духовного центра России. Продолжающиеся столкновения с монголами, вынудили в 1367 году перестроить укрепления в белом камне более или менее в соответствии с линиями нынешнего треугольного ограждения, протяженностью около 2 км. Внешний вид Кремля и города вокруг него трудно представить до XV века поскольку традиционная русская архитектура была эфемерной, построенной из дерева и подверженной пожарам.

K концу XV века вместе с приглашенными итальянскими архитекторами возникли новые архитектурные веяния. Период правления Ивана III (1462-1505) особенно важен. За ним следует период правления его сына Василия III (1505-33). В 1472 году Иван женился на Зое (переименованной в Софию) Палеолог, племяннице последнего византийского императора и претендентки на византийский престол ${ }^{2}$. После падения Византийской империи она бежала к папскому двору в Риме, где она попала под защиту кардинала Виссариона, который впоследствии устроил ее брак с Иваном. Через Виссариона София была связана с греческими и итальянскими интеллектуальными кругами северной Италии и, таким образом, привезла с собой в Москву итальянский ренессанс и византийские веяния. Вскоре после этого итальянские архитекторы заняли видное место в русской истории ${ }^{3}$.

2. A.M. Talbot, Sophia Palaiologina, Oxford Dictionary of Byzantium, том 3. (Оксфорд, 1991), 1928.

3. Shvidkovsky, Russian Architecture, стр.73-104. 
Первым крупным проектом была перестройка Успенского собора в Кремле в 1475-79 гг. под руководством Ридольфо Аристотеля Фиораванти (рис. 5-7). Реконструкция первоначальной церкви была предпринята московскими строителями в 1472 году, но через два года она рухнула, когда уже приближалась к завершению. Консультировались с зодчими из Пскова, но они отказались браться за проект, что вынудило Ивана обратиться к экспертам из других стран. Болонский архитектор Фиораванти был хорошо известен в Италии своими инженерными навыками и дружил с теоретиком Филарете. По прибытии в Россию его отвезли во Владимир, чтобы осмотреть Успенский собор, которому его проект был призван подражать и превзойти (см. рис. 8 и 9). Таким образом, он объединил романские детали, заимствованные из Владимира, с упрощенным двенадцатичастным планом, увенчанный пятью куполами. Фиораванти применил модульный план, по которому все части имели одинаковые размеры, а возвышающиеся над цилиндрическими опорами своды были расположены на одной высоте и перекрывали части без купола.

Чтобы сохранить модульную схему, соединенные часовни по бокам святилища были перекрыты одним куполом. Чтобы придать ему значимость, купол увеличили в масштабе - его диаметр стал больше, чем ширина пролёта, который он покрывает. Вместо отдельного притвора, три западных отсека, все сводчатые, полностью интегрированы в модульную конструкцию. На фасадах детали упрощены; закомары сделаны одинаковыми, части фасада разделены пилястрами, а романские формы порталов и фриз карниза напоминают Владимирский собор. Фиораванти использовал тщательно вырезанный известняк, кладка была закреплена прочным раствором, а свод сооружен из легкого кирпича, укрепленного железными стяжками.

Интерьер напоминает просторный зал, который легко было приспособить для императорских церемоний, так как собор должен был стать коронационной церковью. В последующие века постепенное увеличение иконостаса стало закрывать вид на восточные своды. Хотя иконостас органично сочетается с настенной росписью, он меняет пространственную конфигурацию таким образом, что центральный купол больше не воспринимается в центре, а только как окончание продольной оси наоса с невидимым святилищем за иконостасом. Собор представляет собой тра- диционный русско-византийский архитектурный словарь, переосмысленный итальянским архитектором эпохи Возрождения.

Параллельно с появлением архитектурных идей эпохи Возрождения внедрялись византийские придворные церемонии и идеологии, которые скорее всего пришли с Софьей Палеолог. Иван провозгласил детей от Софии своими наследниками, а не детей от своей первой жены, тем самым застраховав византийскую родословную. В течение нескольких десятилетий мы начинаем находить упоминания о Москве как о «Третьем Риме» и «Втором Константинополе», поскольку Русь взяла на себя роль политического и духовного преемника Византии как оплота православия. С придворным церемониалом появились и придворные титулы; Иван III начал использовать титулы царь (производное от Цезаря) и император.

В 1484-89 гг, вскоре после завершения строительства Успенского собора, был перестроен соседний Благовещенский собор с целью сделать его дворцовой часовней (рис. 8 и 9). Работы выполняли псковские архитекторы, ранее отказавшиеся взяться за восстановление Успенского собора после его обрушения. Церковь вышла значительно меньше и проще; по сути, это была девятичастная церковь с колоннами, установленными на сводчатой структуре, чтобы довести ее до уровня жилых комнат в соседнем дворце к западу от нее. Первоначально она была увенчана тремя куполами, с еще двумя небольшими куполами над часовнями, обрамляющими святилище. Её силуэт был усилен наложенными фронтонами (кокошниками) со стрельчатыми арками. В следующем столетии он был расширен, с крытой террасой, образующей передвижную, увенчанную независимыми купольными часовнями на уровне галереи (1562-64), с двумя новыми куполами, добавленными над западными углами наоса. По сравнению с Успенской церковью, интерьер этого собора относительно тесный, ограниченный знаменитым иконостасом (расписанный Феофаном Греком, Прохором Городецким и Андреем Рублевым), который закрывает святилище и прилегающие к нему часовни. Несмотря на свой статус кафедрального собора, церковь функционировала как частная часовня для молитв членов царской семьи. Особенный по стилю, Благовещенский собор представляет собой продолжение традиционных архитектурных форм, одновременно с новыми веяниями эпохи Возрождения. 
Собор Архангела Михаила в Кремле, построенный около 1505-1509 гг. по проекту венецианского архитектора Алевизе Ламберти да Монтаньяна, продолжил традицию Возрождения, начатую Фиораванти (см. рис. 4). Пятиглавая структура собора повторяет устройство Успенского собора, хотя он был построен меньше по размеру. Его элегантный внешний вид выполнен в классическом стиле, с коринфскими капителями на пилястрах и орнаментальными раковинами в закомарах. Точно так же колокольня Ивана Великого была начата миланским архитектором, известным как Бон Фрязин (1505-8). Её нижние части напоминали отдельно стоящую колокольню в ломбардском стиле, хотя впоследствии она была увеличена и расширена, чтобы вместить двадцать один колокол (см. рис. 4).

Начиная с 1485 г. Кремль укрепляется новыми стенами из красного кирпича по линии старых каменных стен с выступающими башнями (рис. 10). Работа была возложена на российских и итальянских строителей, которые руководили строительством башен. После возведения укреплений жилого квартала Китай-город к востоку от Кремля (1536-39) планировка Москвы стала напоминать Смедерево в Сербии - с цитаделью в стратегической точке большого треугольного ограждения, отделенного от жилого района рвом. В то же время башни отражали тенденции итальянского Возрождения того времени, особенно ломбардской архитектуры. Если не считать более поздние декоративные пристройки, стены Кремля не выглядели бы неуместными в Милане.

В Коломенском, когда-то царской усадьбе над Москвой-рекой, сохранилось несколько церквей, самая важная из которых - церковь Вознесения, построенная после 1528 года в память о рождении Ивана IV и освященная в 1532 году (рис. 11). План беспрецедентный: квадратный наос, расширенный крестообразными выступами, установлен на возвышении. По мере того, как церковь поднимается, верхняя ступень становится восьмиугольной, покрытой пирамидальной крышей шатра, все построено из кирпича. Кокошники появляются на переходе к восьмиграннику, с закомарами у основания крутой скатной крыши. Впервые увиденная здесь шатровая крыша стала заметной особенностью архитектуры эпохи царя Ивана, но ее происхождение неясно. Одна из теорий гласит, что шатровая крыша появилась из местной деревянной архитектуры, хотя образцы этого раннего периода не сохранились (сравните рис. 12) ${ }^{4}$. Следуя этой линии, новые архитектурные формы, представленные в Коломенском, резко контрастируют с итальянскими соборами Кремля и, таким образом, могли бы обозначить консервативную, националистическую реакцию против иностранного влияния.

Недавние исследования выявили детали в стиле итальянского Возрождения (и даже готические) в церкви Вознесения, и документальные свидетельства теперь указывают на то, что за ее дизайн отвечал итальянский архитектор Пьетро Аннибале, известный на Руси как Петрок Малый, тот же архитектор, который руководил строительством стен Китай-города ${ }^{5}$. Для создания 62-метрового здания, для чего требовался фундамент глубиной 9 метров, нужен был квалифицированный инженер. Тем не менее, архитектор, безусловно, осознавал визуальное воздействие традиционных русских форм, о чем свидетельствует применение кокошников и закомар. Следует ли нам отнести шатровую крышу в эту же категорию? Как бы то ни было, похоже, что итальянский архитектор был ответственен за введение определенных форм каменной кладки, тех, которые позже стали интерпретироваться как исконно русские.

Самая знаковая из московских церквей также является самой необычной. Собор Василия Блаженного был построен Иваном IV (Грозным) в память о его победе под Казанью в 1552 году решающем событии в русской истории; строительство церкви было завершено в 1561 году (рис. 13) ${ }^{6}$. Первоначально он был посвящен Покрову Богородицы, но постепенно стал ассоциироваться с Василием Блаженным, юродивым, погребальная часовня которого была пристроена в конце XVI века. Изначально церковь фактически состояла из девяти примыкающих друг к другу часовен, возведенных на возвышении. Восемь часовен по периметру поднимаются на разную высоту и живописно увенчаны своеобразными луковичными куполами. Центральная часовня Богородицы возвышается над остальными и покрыта шатром, увенчанным небольшим позолоченным луковичным куполом. Внутренние помещения высокие и напоминают башни, с максимальным визуальным эффектом, направленным на экстерьер. Луковичные купола на самом

4. Faensen and Ivanov, Early Russian Architecture, стр.437-39.

5. Shvidkovsky, Russian Architecture, стр.111-21.

6. Shvidkovsky, Russian Architecture, стр.126-40. 
деле полые, образованы металлическим покрытием по арматуре; внутри часовня заканчивается довольно скромными сомкнутыми сводами.

Собор Василия Блаженного во многом напоминает декорации, и он соответствующим образом стал фоном для гражданских и религиозных церемоний, посредством которых Москва символически выражала свою идентичность. Главная западная часовня была посвящена Входу Христа в Иерусалим, что стало предметом особой церемонии в Вербное воскресенье: патриарх, проводимый царем, ехал на осле во главе процессии, торжественно воссоздавая вхождение Христа в Иерусалим. Благодаря таким церемониям церковь, а впоследствии и Москва стали ассоциироваться с Иерусалимом.

Один из нерешенных вопросов развития русской архитектуры - появление характерного луковичного купола: имеет ли он особое значение или функцию? Большинство только что обсуждавшихся церквей было построено без них, но они были добавлены в ходе более поздних перестроек. Те, которые находится на соборе Василия Блаженного, несомненно, являются неотъемлемой частью его создания.

Одно из предположений - они функциональны и отводят снег с крыши. Другая гипотеза они отражают форму навеса над Гробом Христа. Возможно, наиболее убедительным предположением является признание исламских форм, принятых в качестве триумфального мотива после Казанской битвы, которая принесла значительные территории Монголии под контроль России 7 . Каким бы ни было первоначальное значение этих куполов, они быстро стали популярными и приобрели собственную символику; их форму сравнивали с пламенем свечи, являющимся маяком Православия.

Не все церкви в Москве похожи на храм Василия Блаженного. Ренессансное переосмысление византийских форм в Успенском соборе нашло заметных последователей, как, например, это видно в Успенском соборе в Троице-Сергиевой Лавре в Сергиевом Посаде (1559-85 гг.), почти точно копирующим его тезку, включая модульный, двенадцатичастный план с пятью куполами и пятью апсидами. Построенное при Иване IV повторение первоначального собора, было предназначено

7. Shvidkovsky, Russian Architecture, стр.128, с примечаниями к работам Брунова, Ильина, Баталова, Вячаниной, Бондаренко. для обозначения власти и связи монастыря с царской семей. Построенный почти одновременно с храмом Василия Блаженного и имеющий одного и того же покровителя, храм отражает стилистическое разнообразие, возможное в русской архитектуре. Другая стилистическая вариация видна в Донском монастыре, основанном в 1591 году на месте отражения нападения татар будущим царём Борисом Годуновым с помощью чудотворной иконы Донской Богородицы (рис. 14). Старый собор, построенный в 1591-93 годах, относительно прост в плане, но его крыша состоит из ряда закомар, поставленных пирамидально и завершающихся луковичным куполом, над высоким барабаном. Как и во многих других примерах впечатляющий внешний вид контрастирует с относительно консервативным интерьером.

Дань России средиземноморью также очевидна в монастыре Новый Иерусалим в Истре под Москвой, основанном в 1656 году патриархом Никоном (рис. 15) ${ }^{8}$. Увеличенная копия Храма Гроба Господня в Иерусалиме, созданная в характерном для России стиле, оказывается значительно более зрелищной, чем его прототип. В то же время монастырь тщательно повторяет строение Иерусалима, основываясь на планах и моделях. Построенный в том же масштабе в плане, что и оригинал, он был значительно выше, с шатром, возвышающимся над ротондой на высоту более 60 метров. Современники Никона, которого в свое время критиковали за самонадеянность, рассматривали здание как оскорбление священного, а не как его осмысление.

В большинстве русских церквей внешний вид был тщательно продуман, а интерьер оставался относительно простым, как того требует православный ритуал. Ярким примером этой тенденции является церковь Преображения Господня на острове Кижи (Онежское озеро), 1714 года постройки, одна из старейших сохранившихся деревянных церквей, (рис. 16 и 17) ${ }^{9}$. Здесь во внешнем виде преобладает повторение деревянных куполов и кокошников, покрытых деревянной черепицей. Хотя это свидетельствует об увлечении декоративными формами, связь с интерьером полностью утрачена: двадцать два купола являются просто креплениями к надстройке.

8. Shvidkovsky, Russian Architecture, стр.169-73; R. G. Ousterhout, Building the New Jerusalem, B Jerozolima w kulturze europejskiy, ред. P. Paszkiewicza и Т. Zadroznego (Варшава, 1997), стр.143-54.

9. Faensen and Ivanov, Early Russian Architecture, стр. 505-11. 
Интерьер представляет собой простой восьмиугольник расширенный по форме креста, перекрытый плоским потолком на уровне трети от общей высоты, со святилищем, визуально закрытым иконостасом, доходящим до потолка. Церковь представляет собой полный отход от первона- чальной византийской концепции: в основе лежит купол, значение которого как обозначение священного пространства может быть аналогичным, но его формальное и архитектурное значение потеряно.

\section{БИБЛИОГРАФИЯ}

1. Callmer, J. 1987, «The Archaeology of Kiev to the End of the Earliest Urban Phase», Harvard Ukranian Studies II, pp. 323-64.

2. Комеч, А.И. Древнерусское зодчество конца X начала XII в. - М.: Наука, 1987. - 320 с.

3. Иоаннисян О., Ивакин Г. 2009. Десятинная церковь в Киеве: старый взгляд нового освещения // Archeologia Abrabamica, Москва, С. 179-202.
4. Ивакин, Г., Иоаннисян, О., Джолшин, Д. 2013. Архітектурно-археологічні дослідження десятинної церкви 2008-2009 pp. // Slovjani I Rus': arheologija ta istorija, C. $73-80$.

5. Швидковский Д. 2007. Российская архитектура и Запад (New Hüvca) 


\section{THE LIAR'S PARADOX - A WILD INTERATION}

\section{P. 2. DIPHTHONG ARISTOTLE-ANOKHIN}

Summary: There are more and more precedents with offended infants of 30-40 years old - they are not emotionally abstinent, because they are in an artificial coma of infantilism, in which 'desire' has replaced 'sacrifice', and are clearly hypocritical, which is why the Holiday of Disobedience, hanging around the planet with a blinking garland of conflicts and wars, creates a turbulent zone in which the bifurcation points are taken out - beyond the orbit of common understanding, turning Consciousness into the quietest Sphinx, producing hypotheses. The saying, willingly or unwittingly, can become a "winged missile" - and destroy the whole world, good or bad, but the theory created by the presentiment of scientific research can help keep it in health and in the flesh of a divine plan, but on one condition: while maintaining peace and the will of Consciousness - the indispensable parity of the Mind, which multiplies both entities and doubt as paradox, whose mental albatrosses format our understanding. Thus, a hypothesis based on a paradox forms

The idleness of the Greeks and Latins (the speculativeness of this denunciation is now accepted a priori) led to the fact that Agon (the Great Helmsman) covered Christianity (the Great Orthodox), under whose umbrella civilization at least lives and vegetates, for the idea of the Messiah (and messianism), having succeeded in the business of constructing an obedient and controlled person, blinding the mind with ready-made formulas of "happiness", depriving the worldview, and even efforts to have it, is an active venture in its manifestations, which, without hiding its transparency, exposes both its greedy strategy to capture the world and the coverage of an uncultivated field stupidity around, in which, thanks to the the Image of the Concept, and thereby builds a fundamental frame of the worldview, without belittling the elephants, and without forgetting the whale. In our world, a liar as Caesar's wife turns out to be beyond suspicion, and, therefore, discussion, and his figure is so transparent and nano-technological that it has long been soldered into the 'scale of errors' of all perception - and this is the toothless sperm whale that substituted its back for the pillars of thinking, which is why not only looms as a wise turtle, but is also perceived by a cheerful Buddha. From time to time, the whale opens its mouth - and we all find ourselves in its throat, and the liar himself is outside the Law, outside the conflict, but in the Law: in the legal field of the Absolute, who knows only the doctrine of exclusiveness and the purple of shamelessness is accustomed.

Keywords: Consciousness, liar's paradox, Image of concept, singularity, 'multiple unity', Meaning, violence, continuum, dichotomy, hypocrisy, capture as a formality.

soil sprinkled with foolishness and irrigation from illusions and false truths, those teeth of the Dragon grow (and very intensively) that will trample the entire civilization at the root, burying all messianism. It's time to throw a stone into this field following the example of Theseus: the demagogy of power, like the demagogy of bliss or truth (coupled with the truth of faith), is just demagoguery - the chatter of winged phrases, but torn off and altered (for example, in the postulates: "Never set foot in the same river twice without changing ...", "For us, the most important of the arts is cinema and the circus, until illiteracy is eliminated ..." - all subordinate clauses were swept aside like last year's snow). Considering 
that the literate population: nobles, merchants, clergy, intelligentsia (engineers, architects, lawyers, scientists, educators, artists, musicians, doctors), the officer estate, the working class (which subscribed periodicals and books, and how the revolutionaries distributed their ideas) - it was "significantly reduced" (like the livestock in a lean year) by the revolutionary Storm, civil Strife and simply by "cleansing" from the bourgeois element - the machine-gun burst by Zemlyachka, then Russia was simply tore up (cutting off the hem of worn-out vestments) and overwhelmed the barefoot tribe of grown up orphans and wounded animals of the World War and Revolutions. And this is said mildly: almost neutral.

A virus, a virus wanders the planet ...- a jokingly thrown paraphrase, but a person who understands is as if mowed down by the plague of consumption. While neurophysiologists are maniacally looking for a "button" for controlling Consciousness, fools are happy with a ship to blissful distances (or just a ticket to the cinema) - it seems that the wrong umbrella is holding Ole Lukøje over us, maybe he got carried away with yoga, froze in the "pose of the logos"? Sleep well, gentlemen! ${ }^{1}$ People slept, and will indulge in dreams to the detriment of "knowledge" always - this is a given, a condition of the task, which should not frighten, but should be considered as 'source code'. Not all and not often will wake up and rush with the passion of Nabokov the entomologist behind the butterfly of meaning - a given worthy of the "Feast of Kings" 2 , and as a double-edged necessity, which gives an understanding of independent movement, and this is the power of your "enlightenment": no one is for you will take not a step, not an inch will not advance all by ourselves, and "divine enlightenment", if it descends, then only if you find yourself in the "field of fools". The realization of a person is a meaningful course of life - in its real run along the ruts and paradoxes of the world flying to all the features, which was and will always be unstable - these are his physical indicators (biometrics - read astrophysicists), in real accomplishment and doing (applying his knowledge and skills, literally according to Ar-

1. That was the title of my article from the practice at the Faculty of Journalism.

2. The painting by P. Filonov, who portrayed the Last Supper in a rather non-canonical way - the Apostles are likened to either otherworldly forces, or zombies, who know the other side of the world, but drawn by emotions, they have access to the dichotomy of understanding: the dual unity of the 'tragic' and the 'comic' - they are characterized by Laughter (as a philosophical aspect). istotle's "Protreptics"), in work and care - it is they that lead to the harmony of existence, rewarding with joy and knowledge. This is the Gift that reproduces the Gift - pure giving through the objects of our material / natural world, including the ephemeral areas - "aesthetic": musical space, and "emotional": love, kindness, empathy. Comprehension, awareness and creation - this is the foundation, the alpha and omega of human existence - not standing on coals, but standing on the whales of human wisdom - and Consciousness is given once (we don't know how many let go into one hand and probably will never know) when birth, and everyone develops it independently (how persistently the "education" of the mind will be carried out depends on everyone, but promises / vows are not taken, as well as loans will not be given in case of default) - this is the prerogative and purpose of the Human, and not to be successful and blessed in his bunker of the same type of "happiness". To be wise is not valor is the duty of everyone, but only everyone should follow the route alone (without a climber), rely on himself, on the forces that are in it - and this is space, whole grain and black earth, and which can be lazy and careless turn into sewage and rancid seed. To speak directly with your own Consciousness: without agents, apostles, magicians, gurus, magi - it is possible, and, most importantly, it should. And this is the "gene of resistance" (private), the very "political reflection" of Man, which gives an explosion of understanding: the happiness of life is in the conscious realization of oneself and in the comfort of the philosophy of the heart, which develops thinking aimed at institutionalizing oneself.

\section{Fermata Cog vs eidos system ${ }^{3}$}

Let us call for the help of a philosopher who was the Teacher of many, including the Great ones, like Alexander: "Memory ( $\boldsymbol{\eta} \boldsymbol{\mu \nu} \boldsymbol{\eta} \boldsymbol{\mu \eta})$ is neither sensory

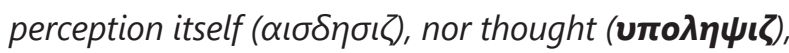
but (is) possession ( $\varepsilon \xi \iota \zeta)$ or enduring $(\pi \alpha \delta \circ \zeta)$ some

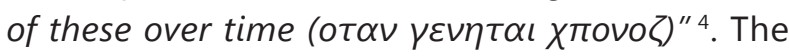
Macedonian was lucky that his Spirit was guiding,

3. Fermata (lit. 'stop') - in musical notation - a sign that increases for an indefinite time the duration of the note or pause over which it is placed. Once Alfred Schnittke signed his score with a 'triple fermata' - it turned out to be "screaming silence". The repetition of the note is due to the complexity of the reasoning - it is given by a 'reminder' in order to indicate, informing the reader, about the 'silence' of the object in question - its inaccessibility, which is useless for philosophical comprehension.

4. Aristotle. On Memory. / Aristotle. Protreptic. On Sense Perception. On Memory. Trans. in rus. by E. V. Alymova. - SPb.: Publishing house of St. Petersburg. University, 2004. P. 139. 


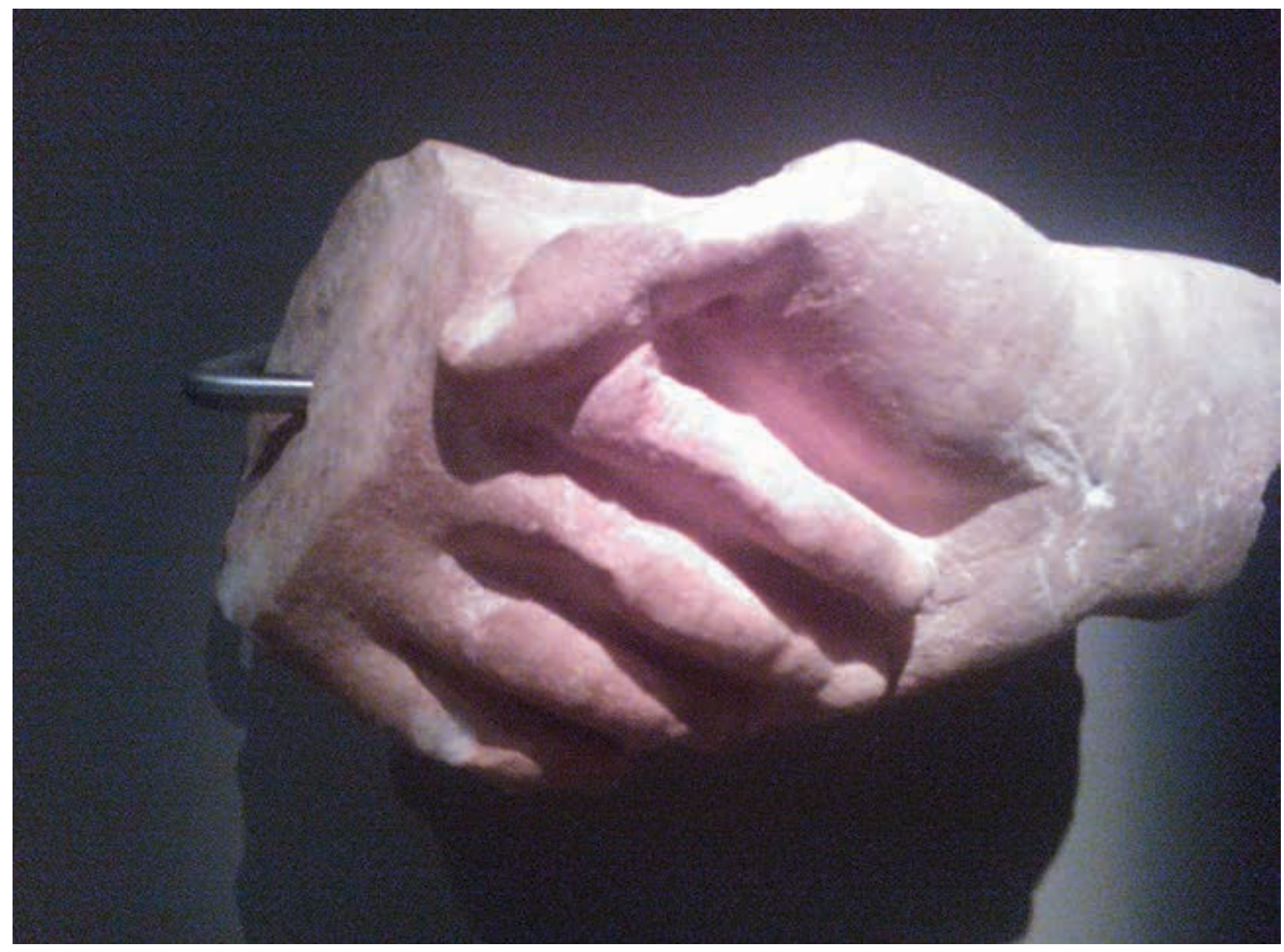

IIl. 1. Скульптура «Рукопожатие» (5-4 вв. до н.э., Археологический музей Афин) - стратегический символ «взаимодействия» древнего «греческого мира», где был распространен культ Митры («бога грании, договора и войны »), где обязательства принято было выполнять априори, но с середины I тыс. до н. э. мировоззрение стало катастрофически меняться - Принципат Обмана трансформировал характеры и государства, сметая границы «свобод и права», исторгая Договор из этического "кодекса чести»

Stagirite, - we often do not have enough teachers, despite the fact that everyone who is not lazy teaches - but the memory ...- they have torn the memory! And with it 'the connection of centuries' - from the place all the shadows are on one side - and the shadows of forgotten ancestors do not disturb the consciousness of people. Meanwhile surprising: everyone is concerned and puzzled precisely by the "problems of Memory", seeing in it sheer paradoxes (!), and, let us note, they hold the masses of people for simpletons, spraying the agitation of "mysteries and finds" of retroculture, telling without having sources and artifacts before their eyes 'stories' about a history that does not know its limits and outlines, because the forgetful Clio, not liking the subjunctive mood, nevertheless loses her sandals - constantly turning back, as if regularly turning your hut "to the forest", filling your 'mansions' with wet nasal, deliberately forgetting about the reverse - revolt is not needed! ${ }^{5}$ - only sometimes,

5. From revolve, revolve, revolutum, ere - 'roll back', 'roll', 'come back', 'go all the way back' [Latin-Russian dictionary. / O. A. Pe- and, not having a written speech, that is, a developed stream of thinking - functionally sharpened, they create far-fetched disputes of questioning, twisting the Sharman a bunch of conjectures, why the Consciousness of many "sleeps" and does not grumble, biting on the deja vu-bit of perceptions, and others, and not always objective, but hard and biting like a wet rag. But the Consciousness that has not milked for a long time, did not bellow, was silent, accumulating its talkative energy - the dark matter of meaning, should avoid not dampness, but indifference to itself. A word by Aristotle: "Memory does not apply to the immediate presence (זou $\left.\pi \alpha \rho \circ \tau_{0} \zeta\right)$ - this is the area of sensory perception $(\boldsymbol{\alpha} \boldsymbol{\iota} \sigma \boldsymbol{\delta} \eta \boldsymbol{\sigma} \boldsymbol{\zeta})$, because with the help of this ability we do not know neither the future nor the past, but only the immediately given. Memory deals with the past

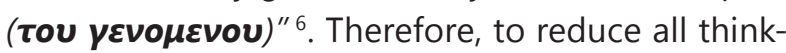
ing to 'memory' on the basis that Stagirite defines

truchenko.- Reprint of the $9^{\text {th }}$ edition of $1914-\mathrm{M} .$. Eksmo, 2017, P. 560].

6. Aristotle. Decree. Op. P. 138. 
recollection, that it builds a chain of memories, as a syllogism, and therefore it is identical to making a decision (то $\boldsymbol{\beta}$ add, as a kind of 'conclusion', to which they came through reflections built in reverse, which is not only unreasonable, but also extremely frivolous, for such tactics lead science into the field of scientometric exercises that they have gotten used to shooting from their machine gun precisely at 'science', moreover, memory is not the only opportunity to stir up / alarm the consciousness - mental perception always beats in your palm like a goldfish, blinking a galaxy in a spiral in the real lava of the present. We conclude that memory cannot be recognized as the main source of thinking / comprehension, and therefore it cannot be an indisputable and only proof that you have consciousness.

Consciousness as a system for thinking (thoughtspeaking) develops a language of comprehension for communicating with itself, in the first place. The language of understanding the world. Depriving the language - pacifying and inspiring their own I, the apostles of the new faith of polyethnicity, monotony and uniforms of lexemes of the English cut, do not just literally rip out the language, creating scientometric rules for the entire planet, tearing out by the roots, like a weed, the native language, and with it the ability to think independently - that is, to independently build syllogisms and algorithms of actions (to bouleuesdai), but in fact, they simply de-energize a person. You don't teach a monkey to speak, if this is not your professional duty - a circus venture? Then why should a writer, philosopher, philologist, surgeon (who is also accustomed to Latin), historian continue to force him to twist his belt in front of a yawning audience? "I - there are different!" - as well as "enlightenments" - self-conscious consciousnesses (SCC) - there can be darkness, it's all about the language, which digs wormholes in its head cortex with images and builds syllogical pyramids with their help, dissolving and braiding transgressive braids of reflections, like hemp ropes, and it is not at all necessary to go to the radiant SCC through yoga - just the opposite: bypassing the eastern bends of meditations, having mastered the language of comprehension - what is for internal monologues and what will certainly grow into writing system is the highest achievement and dignity of Consciousness (not to be confused with the

7. In the same place. P. 150 . language of speaking - with a banal communicative function), it is possible, and so it is, to fall under the volta of Sense - to go through the 'golden gate' and ... laugh at the simplicity of understanding. And then, look around more often: who benefits from making you lame in both legs, piercing the tendons? Who benefits from unverifiable nonsense, whose scientific nature is based on experiments with mentally unhealthy mice, on the analysis of aborted or decomposed material, when tracing other people's methods, that is, from the heralds conditionally in the subjunctive mood?

We admit, because it is a fact that modern philosophy has become like scholasticism - it came out of it without closing the door behind itself, preserving a wide field of possibilities for the latter and that, centuries later, like ivy, it spread like ivy, mimicking, acquiring new nicknames - postmodernism, structuralism, transhumanism ...- this evergreen "lawn", accustoming to irresponsible and groundless phrasing (here he is Apotheosis, Mr. Shestov!), Helpfully and caringly soft, like prayer rug ${ }^{8}$, and comfortable, like puzzles: assembled, dismembered, folded,-flooded with itself all imaginable and poorly guarded spaces: transcendental tendrils (which is your tradescantia) pull their scholastic codes to neurolinguistics, biomechanics and artificial intelligence - raise kids! And amazing plants bloom on this field! For example, how can one be "alarmist" (confessions are accompanied by almost tapping on the chest) with a doctorate in philological and biological sciences? This is either verbal trickery, or a well-known eccentricity in his declining years - that non-commissioned officer's widow who whipped herself - stupidity that counts on the stupidity of others who listen with Bandar-log's trepidation the lingua-mazurka by Chernigovskaya, falling into a comatose from a rare verbal speaking - literally in Khlestakov's crawl style: about everything and at once, but thus, proud of her "alarmism", a learned lady, pulling up her professorial uniform with a distinctive button, demonstrates its lining: "panic", "mislead", "to spread unverified, unfounded rumors, causing alarming moods of the property" ${ }^{\prime}$, or signs in their own ignorance, because the philologist should not be ignorant of the meaning of words, or she is from the retinue of the Cynic - without batting an eye

8. A prayer rug (Arabic, sajadat, musalla, bisat, hasir, humra; Persian - jainamaz; tat. - namazlyk; budd. - futon) - a rug for prayers, meditations.

9. Dictionary of foreign words.- M .: Sirin, 1996. P. 25. 


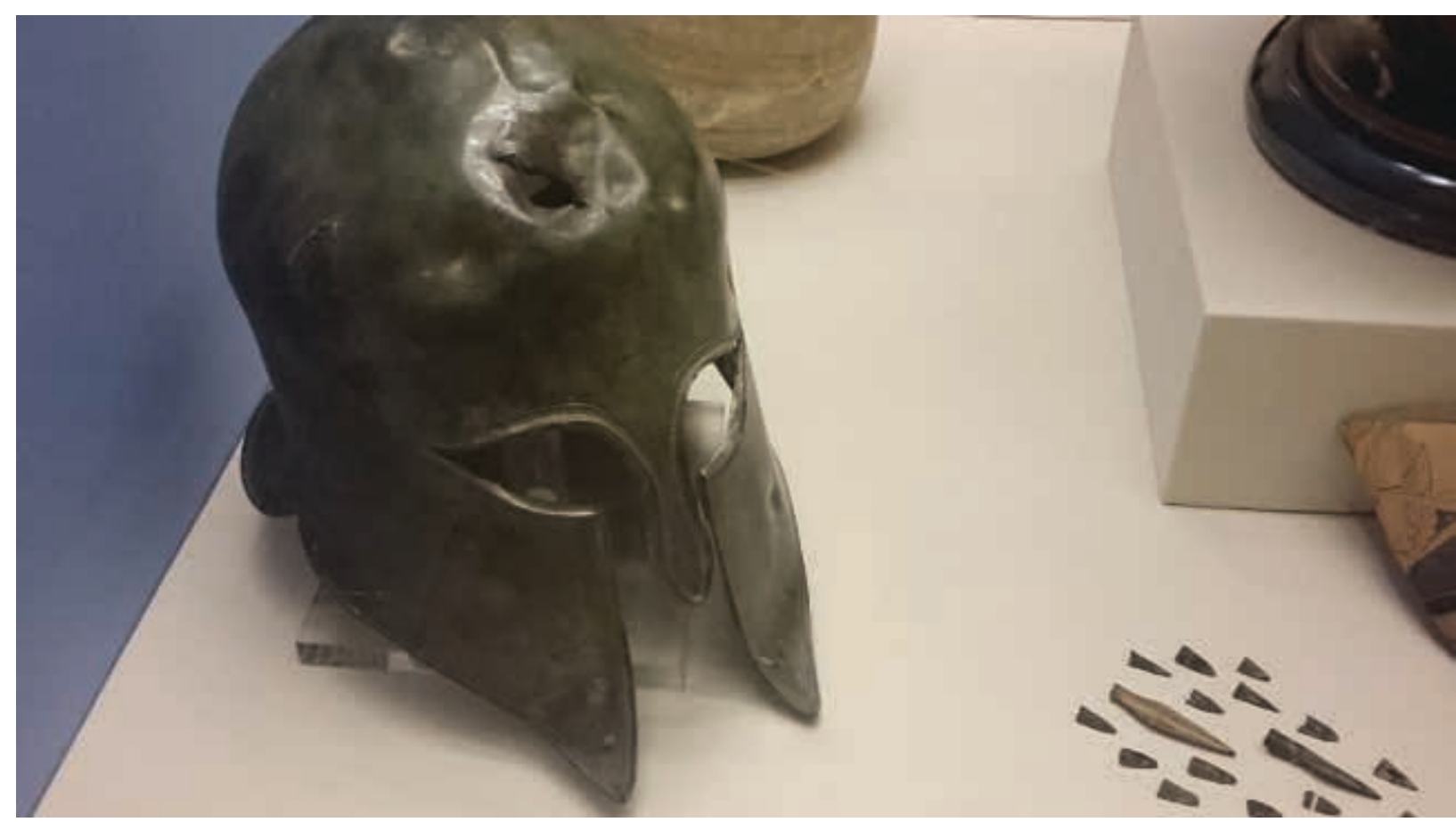

Ill. 2. Пробитый в бою бронзовый шлем - «Коринфский» - самой популярной формы среди греческого населения середины I тыс. до н.э. (500-450 гг. до н. э., Британский музей) - прямой свидетель «контактного» взаимодействия племен и народов - отверстие в шлеме проделано силой одного воина-гибриста, метнувшего свое копье с целью продемонстрировать свою «исключительность» и свое «право на нее»

announces the purpose of her speech: to make the ignorant stupid. Are these the modern apostles of the scientific faith? Lomonosov is not on them! And Krylov. But our mind should not sleep, or is it waiting for indignation, which brings it to a boil, and then for Mozhay? Shukshin's book about Stepan Razin was called "I came to give you freedom" - what kind of will were you talking about? Was there any other meaning in the title, except for the emancipation of enslaving, civil liberties? It seems that Vasily Makarovich, with all his craving for imagery, allegorical and paradoxical expression (hardening and playfulness of the mind), could have in mind something else - for example, the will to comprehend, his own, the will to single-handedly control his own reason and actions. The professor does not promise you this - on the contrary, he takes away the will and faith in oneself, telling: the brain is unknowable, deep and wayward - practically in Dante style: "Give up hope, everyone who enters here!" in a word, everyone to sleep! Perhaps sleep is not the best medicine, and, contrary to the advice of doctors, sometimes it is "worse than kerosene" 10 ?

Science, preoccupied with mapping its own fins, has engaged in reduction instead of deduction: it dissects frogs from the Milky Way, abandoning the general -

10. A proverb from the movie "The Magic Ring" based on the fairy tale of the same name by Boris Shergin. the prospects for understanding the "infinite diversity of information" (consciousness), indulges in fascinating specifics - not all the connections between neurons (and then - suddenly half will extramarital?), but only such sets of them, the activation of which corresponds to the units of cognitive experience, and in order to make the experiment unique, they scan the brains of fish, mice, rabbits and macaques - they certainly will not share either aisdhst (sensory perception) or upolhyi (thought), will be silent, but who cares about Stagirite in the era of smartphones, when it is not the Sense that is important, but the picture of flickering lights, which are so exciting to count. At least one goldfish shared its sensory perception not of a worm - of cold streams, did a nocturne play on them?! At least one macaque shared an idea how difficult it is to raise children? Has any rat revealed its speculative sensory perception of the death of its cage-mate / cagemate to inquisitive "cognitive" researchers ${ }^{11}$ ? This whole 'session of black magic' - hypnotic sketches could be considered as dancing with a tambourine in chilly weather, but using natotechnology in diagnostics and pharmacology destructive to DNA, apparently counting on transgenic mutations (the novelty gene c-fos), one can assume that they were targeting hu-

11. A term proposed by the Russian neurophysiologist K. Anokhin. 
manity, which, due to the absence of world wars (local conflicts do not count), somehow gained weight.

And in order not to be unfounded in the reasoning, I nevertheless decided to back up my thoughts with arguments - not Damascus steel, not all-sheet paper, but only materials of oral presentations were found (all the indicated articles turned out to be stacked in PDF). I am citing a fragment of one such and without cuts, so that "...... the identity of each was visible", as by the decree of Peter I, and it was not I who did not seek out, but began to read the first site that the virtual world offered, - it happened "according to the saying" that like a winged Nika, always runs to a catcher - performances (apparently on the radio) turned out to be enough for me to make sure that my final chords chose the correct key - a mental quark, or, in the spirit of Democritus - an alarming eidos that I was not restrained in flight, that your Chkalov. For ease of reading, I will place my claw about the readable and comprehensible judgment of Mr. Anokhin, the inventor of the cognitome, next to the subject's sentence on the truth of my opponent's phrase - so, my commentary, which arises when reading immediately after perception (continuum), is put in square brackets and in italics, thereby creating transgression currents ('movement through') - the very sought-after rotation of mental 'matter', and thus the reader will be able to observe the 'work' of Consciousness, so to speak 'at work' and 'in working mode', that is, to comprehend my comprehension as a 'mental perception' - according to Aristotle, and not according to the "New Testament" introductions to the natural counting of the infinite set. Consider this a method of contamination, similar to the one with which our immersion in "Heart of a Dog" began, it was Bulgakov himself who used it, placing the inner monologues of the dog Sharik - the commentator after the replicas of human characters - in a word, the oldest fictional method, for art is called upon not so much to reflect all the flashes and articulations in the spiral Fibonacci trifle - how to understand and accept it as a 'universe' - a world without borders, but in the proportions of common sense faceted beauty, just for you, by you, for others, for the good - and therefore in advance - for the em-

\section{bodied image.}

These are the words not of a boy, but of a husband ${ }^{12}$ : "Today there are microscopic methods that

12. Cit. the text "Will cognition become the golden key to the mystery of consciousness?", which is a detailed interview- allow performing the finest layer-by-layer scanning with a resolution that captures individual neurons. Thus, there is a fundamental possibility to experimentally isolate the neural ensemble responsible for the elementary unit of cognitive experience. This is an approximate experimental plan with a thin dotted line (so for 10-15 years ahead). [and back? of course 'forward' is not Benjamin Button! not otherwise I have outlined two lives for myself!] Now what do we have on the theoretical part. [colloquial speech betrays the political instructor - purely foraging!] First, as it should, we have a new concept (eidosJ) cog! [the new is like a well-forgotten old - no one will definitely show copyrights!] This is a combination of an elementary neural network and a single cognitive experience corresponding to it. The complete set of cogs in the individual consciousness, formed in the process of evolution, development and cognition of the individual, is called COGNIT (this is, in consonance with the genome, the scope [or washed out?] For the future, as it were, can be seen). In general, in its abstract essence [??? how did you intend to catch abstractions?] with cognition is nothing more than a hypernet. A hypernetwork is such a thing [for a doctor of sciences it is very banal: colloquial speech does not 'define'], in which each set of connected elements of the lower-level network (neural ensemble) in a certain way corresponds to an element of the upper level (cog) - [bah, brothers! then the principle of the pyramid!]. Such a volumetric unit of a hypernetwork is called a hypersimplex. And, remarkably, lower-level ensembles may well overlap. And due to such intersections, associative connections between cogs are built (aha! As well as thought chains in our head). [not always chains as a rule, dud! poems have not tried to read to understand it? to catch the intersection of associations? judging by this quote, little Kostya loved most of all in his childhood to decorate the Christmas tree with garlands - a passion for lights at different heights and even with intersections!] Thus, cogs are all connected into one grainy [?? have you seen?] structure: and as soon as one cog is activated, all those cogs in which there are at least a few common elements with the first cog are immediately activated. [here's the news! metaphor always works on similarity and contiguity] That is, cognition is not just a set of elements, but a complexly connected set. [how it

presentation of Doctor of Biological Sciences K. Anokhin in the electronic journal Evolution, 2014, July 14, 8:25 (pm) [www. evoluziya.livejournal.com]. 
conjures!] And so, here and its own difficult mathematics is visible: in particular, the formalism and metric of the theory of hypergraphs. And it's great that it is, mathematics! [because you count all the female rhymes, will you understand Shakespeare? or so you will look for the source of his homosexuality? bookkeepers!] This means that the developed new concept - "cognitive science" - is formalized in principle, and not just some kind of philosophy about a pitchfork on the water. [more precisely, you cannot say about the pitchfork, and about yourself, my dear, - I handed it over with giblets! this is where the pitchfork is, so the pitchfork is a catch, that, using the denotation of "meaning," 'does not set it as a goal', and is proud of its direct borrowing, as if not noticing it. Cognitum - understanding, but here delight - to count the chips! I remember that in one fairy tale they also loved the passion of how to count everything that moves and puffs up, grows and disappears - the moles from "Thumbelina", but they were blind .... What are the prospects for the mysterious "Cheshire" cog? And in the fact that it combines the objective-material (the neural basis of consciousness) and the subjective-ideal (actually an element of consciousness, a unit of cognitive experience, a mental quantum). That is, it is quite possible to expect that when he turns out to be the missing link, the stitch that will sew the gaping gap between neurophysiology and neuropsychology, [they spoke about Sharikov in the same pompous manner], reconcile the mind and the psyche, decide with one (or maybe not one) in a stroke the "damned" psychophysiological problem. " [OH!!! Gods! Where are your ears! Damn it? How appropriate it would be! As a handkerchief brought up in time - like a match - in the non-idle business of population reduction - everyone is damned! - all into the oven! After all, they are worthless - they have problems with the brain and psyche! And eternal! Wait, isn't the psyche inside the brain? Or had her brain refused to let her stay? Where can she go, poor? - not otherwise than in cognitome - it will shelter and warm the entire set of neurons of the hypernet. There is a hole of understanding per square centimeter of a single experience: "take the trouble to explain: who stood on whom?"]

Let us summarize the bottom line: the need for cognition - cognuitio - as "study and cognition with the mind and feelings", that is, as a "realized necessity" of existence, despite the agitation of the self-pro- claimed term, disappeared like Sharikov's canine tail - left by COG, as an atavism, and as an object 'color pictures', which is a tomograph with animation, putting up the tree of knowledge for sale with a Christmas tree with lights, which in the age of Figures is more relevant to consider than to admire.

So, the re-evolution of scientific knowledge is obvious - at the bottom of the back - and we started with this - from the pitch world, which turned into reality, a farce. The style of "canine cues" is observed - and we have the result: truly, an intelligible experiment: a number! invisible quarks - revealed by "shining nonsense" ${ }^{13}$. These are the three constituent parts of the modern "Marxism": genome - connectome (the totality of connections between the parts of the brain) - cognitome (the sum of the elements of individual experience), where the middle type, acting in the role of "English political economy", creates its "aggregate" based on the experience of strangers (mice they will not write a scientific report for themselves, they will not squeak "Spine Flute") ${ }^{14}$. And how will the socialist-utopian cognitome mix with the external medium (the experimenter), how will he merge into his 'connect', copulating between the parts of the brain, what does he think of himself as Napoleon? The mixing will be carried out by a Nietzsche-ventriloquist? The connect diggers ${ }^{15}$ remembered (inflamed with memory) the forgotten eidos of the Greeks that ensured the run of Entelechia, but they took the Latin wafer, customary for pronunciation - the English cut, which is popular out of necessity, or supposed benefit according to Caesar.

13. Preobrazhensky's statement about Sharikov's boots ("Heart of a Dog" by M. Bulgakov).

14. The three sources and three nodal centers of Marxism are "German philosophy, English political economy, French socialism." [Lenin V.I. Three sources and three components of Marxism. Full collection Op. T. 23.]

15. Connectome is a collection of all connections in the brain, a term introduced in 2005 by Olaf Sporins, Giulio Tononi and Rolf Kötter (Fogton Institute for Brain Research in Düsseldorf) ["PLoS Computation Biology", 2005, 1 (4), e42.] - that is, such a collective embryo. In the same year, Patrick Hagman uses the same word in the theses of his Ph.D. thesis, calling so "the totality of all connections in it as a single one". It seems that such a "unity" of thoughts became due to the knowledge of Latin, or simply their native language, which was formed on its basis, entering the Romano-Germanic family of the IndoEuropean group of languages: connecto, nexui, nexum, -1) to connect, weave, weave, by tying, weaving; 2 ) to connect - to directly attach, in time, to compose from parts [Latin-Russian dictionary. / O.A. Petruchenko.- Reprint of the $9^{\text {th }}$ edition of 1914 - M.: Eksmo, 2017, P. 127]. 


\section{REFERENCES}

1. Aristotelis fragmenta selecta / Recognovit W.D. Ross. Oxford, 1955. Quotes are from the Russian translation: Aristotle. Protreptic. Sense and Sensibilia. On memory. / Russian translation: E. V. Alymova.- SPb.: Publishing house of St. Petersburg University. 2004. p. 183

2. Ancient theories of language and style. Under the general editorship of O.M. Freidenberg.- MoscowLeningrad: State Socio-Economic Publishing House, 1936. p. 343

3. Roland Barthes. S/Z.- M.: Editorial URSS, 2011. p. 232

4. Aulus Gellius. Attic nights. Books I-X / Trans. from Latin under the general. Ed. A. Ya. Tyzhov.-SPB.: IC "Humanitarian Academy", 2007. p. 480

5. Homer. "Odyssey". Trans. from ancient Greek. V. Zhukovsky. Canto XXII [St. 295, St. 306-309].- M.: Pravda, 1984, p. 272.

6. Greek epigrams (VII century BC-IX century AD). Translation, article and notes by L.V. Blumenau.- MoscowLeningrad: ACADEMIA, 1935.- p. 316.

7. Greek-Russian dictionary, compiled by A.D. Veisman.St. Petersburg, 1899.- Reprint of the V-th ed.- M.: Yu. A. Shichalin's Greco-Latin Cabinet, 2011.

8. Ingarden Roman. Essays on the philosophy of literature.- Blagoveshchensk: BGK im. I. A. Baudouin de Courtenay, 1999. p. 184

9. A short dictionary of Latin words, abbreviations and expressions. / Comp. V. Kupreyanova, N. Umnova. - M.: TERRA, 1996, p. 75.

10. Kulakovsky, Yu. A. 2002. Eschatology and Epicureanism in the Ancient World, SPb., p. 256

11. Latin-Russian dictionary / O.A. Petruchenko.- Reprint of the $9^{\text {th }}$ edition of 1914 - M.: Eksmo, 2017.

12. Linguistic encyclopedic dictionary. 1990. Moscow, p. 584.

13. Losev, A. F. 2005. Higher synthesis. Unknown Losev.M.: "CheRo", p. 264

14. Mamardashvili, M. K. 1996. "Introduction to philosophy", Need yourself, Moscow, p. 130.

15. Menshikova, E. R. 2020. "The double axe of myth (diphthong of Song): the forgotten flute of Greek Epigram justification of vileness, or total transformation "according to Fahrenheit" (cynic paradox) ", Art Literature Scientific and Analytic Journal Burganov House. The Space of Culture, vol. 16, no. 3, pp. 19-32. DOI:10.36340/20716818-2020-16-3-21-46.

16. Menshikova, E. R. 2016. "On the problem of interpretations of the neologism "utopia"", Antiquity as the genome of European and Russian culture. SPb, pp. 237282.

17. Menshikova, E. R. 2017. "Myth as a natural exchange (epistemological aspects of practical lies)", CredoNew, no. 1-3.

18. Menshikova, E. R. 2019. "The natural landscape of philosophy (the political reflection of Heraclitus and Aristotle)", Art Literature Scientific and Analytic Journal Burganov House. The Space of Culture, vol. 15, no, 4, pp. 24-42. DOI:10.36340/2071-6818-2019-15-4-24-42
19. Menshikova, E. R. 2012. "Receptive curse or terminological failure: to the problem of interpreting T. More's neologism "utopia"", CredoNew, no. 3-4.

20. Menshikova, E. R. 2019. "Rondo of Myth: "Trojan terrorism" as an idea of exclusivity, or Caesar's summum bonum: conquer the world by violence!", CredoNew, no. 2.

21. Menshikova, E. R. 2019. Trojan terrorism as a principate of Deception, or in the arms of the terracotta locust (etymological wingcases of virtus). Parts. 1-3, CredoNew, no. 3-4, no. 1.

22. Menshikova, E. R. 2018. "Trojan terrorism as an established order (disciplina), or the nomadic colonatus (mission of Myth in the space of Sir T. More's "Utopia")", CREDO New, no. 2.

23. Menshikova, E. R. 2018. "Trojan terrorism: revenge of the colonists or condition of evolution? (to the problem "Your / Alien")", CREDO New, no. 1.

24. Menshikova E. R. "Utopia: Reseptive curse or terminological failure - The problem of interpreting the Thomas More's neologism of utopia" / XXIII World Congress of Philosophy "Philosophy as Inquiry and Way of Life". Abstracts. - Athens 04-10. August 2013. University of Athens, School of Philosophy University Campus - Zografas.

25. Menshikova, E. R. 2017. The natural landscape of philosophy (political reflaction of Heraclitus and Aristotle). $/ / 29^{\text {th }}$ International Conference of Philosophy "Greek moral and political philosophy-From Pre-Socratics to Neo-Platonism" (Jule 7-11, 2017, Rhodes). Paper Abstracts. - Rhodes, 2017.

26. Menshikova, E. R. 2018. "The Natural Landscape of Philosophy (The Political Reflection of Heraclitus and Aristotle).", Philosophy Study, vol. 8, no. 1.

27. Menshikova, E. R. 2018. "The Troyan Terrorism as an Established Order (Disciplina), or the Nomadic Colonatus (Mission of Mith in the space of Sir Thomas More's "Utopia")", International Relations and Diplomacy, February 2018, vol. 6, no. 2, (Serial Number 53).

28. Menshikova, E. R. 2018. "The Trojan Terrorism: Revenge Colonists or Condition of Evolution? (To the Problem "Your/Alien")", Philosophy Study, vol. 8, no. 4.

29. Panofsky Erwin. IDEA: Towards the History of the Concept in the Theories of Art from Antiquity to Classicism.- SPb.: Andrey Naslednikov, 2002.- 237 p.

30. Pöhlmann Robert von. Essay on Greek history and source studies. / Trans. from German. A.S. Knyazkov, ed. Prof. S. A. Zhebelev. / Scientific. ed. $4^{\text {th }}$ edition 1910 St. Petersburg: "Aletheya", 1999.- 471 p.

31. Plutarch. Oeuvre. / Trans. from ancient Greek. T.G. Sidash.- SPb.: Publishing house of St. Petersburg University, 2008.- 384 p.

32. Piatigorsky Alexander. What is political philosophy (lecture cycle).- M.: Publishing house "Europe", 2007.

33. Ricoeur Paul. The Conflict of Interpretations. Essays in Hermeneutics / Trans. And introductory article: I. Vdovina.- M.: "CANON-pess-Ts"; "Kuchkovo field", 2002.$624 \mathrm{p}$. 
34. Dictionary of foreign words. $7^{\text {th }}$ scientific editor. rework. ed.- M.: Sirin, 1996. -608 p.

35. Theophrastus. Characters. Trans., Article and approx. G. A. Stratanovsky. Reprint ed. 1974.- M.: "Nauka", 2007.- 124 p. Freidenberg O. M. Image and concept. / Freidenberg O.M. Myth and literature of antiquity.M.: Ed. firm "Eastern Literature" RAS, 1998. P. 223-622.

36. Freidenberg, O. M. "The characters" of Theophrastus.Scientific notes of Leningrad State University. No. 63. Ser. philol. Sciences 1941, no. 7, pp. 129-141.

37. Thucydides. History. / Trans. F. G. Mishchenko and S. A. Zhebelev, ed. E. D. Frolov.- SPb.: "SCIENCE", "YUVENTA", 1999.
38. Gaius Julius Caesar. Commentaries on the Gallic War. Books two, three and four. With an introduction and comments by S.I. Sobolevsky.- [Moscow: Publishing House of Literature in Foreign Languages, 1946] / Moscow: Russian Foundation for the Promotion of Education and Science, 2011 - Unadapted text <C. Julii Caesaris. Liber Secundus. XII (1)>].

39. Shirokov, O. S. 2003. Linguistics: an introduction to the science of languages.- Moscow, p. 126. 


\section{ПАРАДОКС ЛГУНА — НЕВЕРОЯТНОЕ ПОВТОРЕНИЕ}

\section{2. ДИФтонг Аристотель-Анохин}

Аннотация. Прецедентов с обиженными инфантами 30-40 лет становится всё больше - они эмоционально не воздержаны, ибо находятся в искусственной коме инфантилизма, в которой 'желание' заменило 'жертвенность', и явно лицемерны, отчего Праздник непослушания, развешивая вкруг планеты мигающую гирлянду конфликтов и войн, создаёт турбулентную зону, в которой точки бифуркации вынесены наружу - за орбиту здравого понимания, обращая Сознание в тишайшего Сфинкса, плодя гипотезы. Крылатое выражение вольно-невольно может стать «крылатой ракетой» - и разрушить весь мир, плох он или хорош, но теория, создаваемая предчувствием научного поиска, может помочь сохранить его в здравии и во плоти божественного замысла, но при одном условии: при соблюдении покоя и воли Сознания - непременном паритете Ума, что парадоксами множит как сущности, так и сомнение, чьи ментальные альбатросы форматируют наше понимание. Так гипотеза, основанная на пара-

Праздность греков и латинян (умозрительность этого нарицания принимается сейчас априори) привела к тому, что Агон (Великий Кормчий) накрыло Христианство (Великое Ортодоксальное), под зонтиком которого цивилизация худо-бедно живет-прозябает, ибо идея Мессии (и мессианства), преуспев в деле конструирования человека послушного и управляемого, ослепляя разум готовыми формулами «счастья», лишая мировоззрения и даже усилий его иметь - затея активная в своих проявлениях, что, не скрывая своей прозрачности, обнажает и свою алчную стратегию по захвату мира, и охват непаханого поля глупости вокруг, в котором, благодаря сдобренной нера- доксе, формирует Образ Понятия, и тем самым строит фундаментальный каркас мировоззрения, не умаляя слонов, и не забывая кита. В нашем мире лжец (он же лгун) как жена Цезаря, оказывается вне подозрения, и, значит, обсуждения, а его фигура столь прозрачна и нано-технологична, что давно впаяна в 'шкалу погрешностей' всякого восприятия, - и это тот беззубый кашалот, что подставил свою спину столпам мышления, отчего не только маячит мудрой черепахой, но и воспринимается весёлым Буддой. Время от времени кит открывает свой рот - и все мы оказываемся в его глотке, а сам лжец - вне Закона, вне конфликта, но в Праве: в правовом поле Абсолюта, которому ведома только доктрина исключительности и привычен пурпур бесстыдства.

Ключевые слова: Сознание, парадокс лжеца, Образ понятия, сингулярность, 'множественная единичность', Смысл, насилие, континуум, дихотомия, лицемерие, двоемыслие, формальный захват.

зумием почве и орошению из иллюзий и ложных истин, произрастают (и весьма интенсивно) те зубья Дракона, что вытопчут всю цивилизацию на корню, похоронив всякое мессианство. Пора бросить в это поле камень по примеру Тесея: демагогия силы, как и демагогия блаженства или истины (вкупе с истиной веры), всего лишь демагогия - болтовня крылатых фраз, но оборванных и переиначенных (н-р, в постулатах: «Нельзя в одну и ту же реку войти дважды, не изменившись...», "Для нас важнейшим из искусств является кино и цирк, пока не будет ликвидирована безграмотность...» - все придаточные отметались как прошлогодний снег). Если учесть, что 
грамотное население: дворяне, купечество, духовенство, интеллигенция (инженеры, архитекторы, юристы, учёные, педагоги, художники, музыканты, врачи), офицерское сословие, рабочее сословие (что выписывало периодику и книги, а то как бы революционеры распространяли свои идеи) было «значительно сокращено» (словно поголовье скота в неурожайный год) революционной Бурей, гражданской Распрей и просто «зачистками» от буржуазного элемента - пулемётной очередью Землячек, то Россию просто рвало (обрывая подол изношенных риз) и переполняло босоногое племя подросших сирот и подранков Мировой войны и революций. И это сказано мягко: почти нейтрально.

Вирус, вирус бродит по планете... - шуткой брошенный парафраз, но человека осмысляющего словно выкашивает чума потребления. Пока нейрофизиологи маниакально ищут «кнопку» управления Сознанием, глупцам довольно корабля в блаженные дали (или просто билета в кино) видно, не тот зонтик над нами держит Оле-Лукойе, быть может, увлекся йогой, застыл в «позе логоса»? Спите спокойно, господа! ${ }^{1}$ Люди спали, и будут предаваться снам в ущерб «знанию» всегда - это данность, условие задачи, что не должно пугать, но стоит учитывать как 'исходный код'. Пробуждаться и нестись со страстью Набокова-энтомолога за бабочкой смысла будут не все и не часто - данность, достойная «Пира Королей» ${ }^{2}$, и как обоюдоострая необходимость, что наделяет пониманием самостоятельного движения, и в этом сила вашего «просветления»: никто за вас не сделает ни шага, ни на дюйм не продвинется - все сами, а «божественное просветление», если и снизойдет, то исключительно если вы окажетесь на «поле дураков». Реализация человека - это осмысленное протекание жизни в её реальном беге по рытвинам и парадоксам летящего ко всем чертям мира, который был и останется нестабильным всегда, - это его физические показатели (биометрика - читайте астрофизиков), в реальном свершении и делании (применении своих знаний и умений, буквально по «Протрептику» Аристотеля), в труде и заботе -

1. Так называлась моя статья с зачётной практики на журфаке.

2. Картина П. Филонова, что изобразил Тайную Вечерю довольно не канонически - Апостолы уподоблены то ли потусторонним силам, то ли зомби, которым ведома изнанка мира, но влекомым эмоциями, им доступна дихотомия понимания: двуединства 'трагического' и 'комического' - им свойственен Смех (как философский аспект). именно они приводят к гармонии существования, вознаграждая радостью и познанием. Это Дар, воспроизводящий Дар - чистое дарение через предметы нашего вещного/природного мира, включая области эфемерные - «эстетическое»: мусическое пространство, и «эмоциональное»: любовь, доброта, эмпатия. Осмысление, осознание и созидание - вот фундамент, альфа и омега человеческого существования - не стояние на углях, но стояние на китах человеческой мудрости - и Сознание даётся один раз (сколько отпускают в одни руки, мы не знаем и, вероятно, никогда не узнаем) при рождении, и каждый развивает его самостоятельно (насколько упорно будет вестись «воспитание» ума, зависит от каждого, но обещаний/клятв не берут, как и кредитов не дадут в случае дефолта) — такова прерогатива и назначение Человека, а не быть успешным и блаженным в своем бункере однотипного «счастья». Быть мудрым - не доблесть обязанность каждого, но только каждый должен идти по маршруту один (без скалолазочки), полагаться на себя, на те силы, что есть в нём а это космос, цельнозерновой и чернозёмный, и который может по лени и беспечности обернуться сточной водой и прогорклым семенем. Говорить с собственным Сознанием напрямую: без агентов, апостолов, магов, гуру, волхвов возможно, а, главное, должно. И это есть «ген сопротивления» (частного), та самая «политическая рефлексия» Человека, что даёт взрыв понимания: счастье жизни - в осознанной реализации себя и в утешении философией сердца, что вырабатывает мышление, направленное на институализацию себя.

\section{Фермата кога vs система эйдосов ${ }^{3}$}

Сознание не терпит пустоты, как и природа, «гномы» великих нам помогают свет найти в конце тоннеля, творить чудеса, и, вместе, быть одиноким и пустынным. Призовём в помощь философа, что был Учителем многих, включая Великих, как Алек-

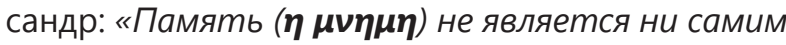

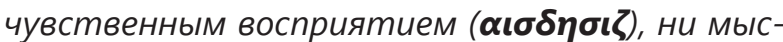

3. Фермата (букв. 'остановка') - в нотном письме - знак увеличивающий на неопределенное время длительность ноты или паузы, над которой он поставлен. Однажды Альфред Шнитке подписал свою партитуру 'тройной ферматой' - получилось «кричащая тишина». Повтор примечания обусловлен сложностью рассуждений - дан 'напоми нанием', с тем чтобы обозначить, предуведомляя читателя о 'молчаливости' рассматриваемого объекта - его недосягаемости, что для философского осмысления бесполезно. 


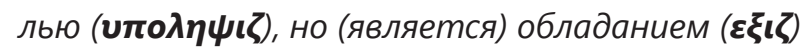

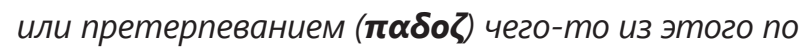

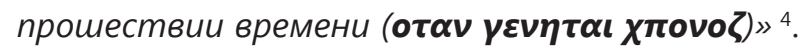
Македонскому повезло, что его Дух направлял, Стагирит, - учителей нам часто не хватает, при том, что учат все кому не лень, - но память...порвали память! А с нею 'связь веков' - с места все тени набекрень - и тени забытых предков не тревожат сознанье людей. А между тем удивительно: все озабочены и озадачены именно «проблемами Памяти», видя в ней сплошные парадоксы (!), и, заметим, держат массы людей за простаков, распыляя ажитацию «загадок и находок» ретрокультуры, рассказывая, не имея источников и артефактов перед глазами 'истории' про историю, что не знает своих пределов и очертаний, поскольку забывчивая Клио, не любя сослагательное наклонение, все же теряет свои сандалии, - постоянно возвращая вспять, как бы регулярно поворачивая вашу избушку «к лесу», заполняя мокрым гнусом ваши 'хоромы', намеренно забывая о реверсе — revolt не нужен! ${ }^{5}$ лишь иногда, и, не обладая письменной речью, то есть развитым потоком мышления - функционально наточенным, создают балаганные диспуты вопрошания, крутя шарманку домыслов, отчего Сознание многих «спит» и не ропщет, закусывая дежавю-удила восприятий, причём других, и не всегда объективных, но жёстких и хлёстких, как мокрая тряпка. Но Сознанию, что долгое время не доилось, не мычало, молчало, накапливая свою говорливую энергию - тёмную материю смысла, должно избегать не сырости, но равнодушия к себе.

Слово за Аристотелем: «Не относится память и к непосредственному наличному (тои парогто乙) - это область чувственного восприя-

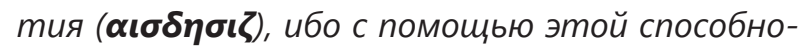
сти мы не познаём ни будущее, ни прошлое, но только лишь непосредственно данное. Память

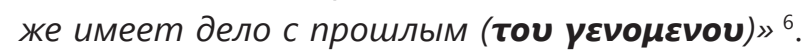
А потому сводить все мышление к 'памяти' на том основании, что Стагирит определяет припоминание, что выстраивает цепочку воспоми-

4. Аристотель. О памяти. / Аристотель. Протрептик. О чувственном восприятии. О памяти / Пер. на рус. Е. В. Алымовой. - СПб.: Изд-во С.-Петерб. ун-та, 2004. С. 139.

5. От revolve, revolve, revolutum, ere - 'назад катить', 'скатывать', 'возвращаться', 'обратно проходить весь путь' [Латинско-русский словарь / О.А. Петрученко. - Репринт 9-го издания 1914 г.- М.: Эксмо, 2017, С. 560].

6. Аристотель. Указ. соч. С. 138. наний, как силлогизм, и оттого он тождественен принятию решения (то $\boldsymbol{\beta} о \boldsymbol{\lambda} \boldsymbol{\varepsilon} \boldsymbol{\varepsilon} \boldsymbol{\varepsilon} \boldsymbol{\sigma} \boldsymbol{\delta} \boldsymbol{\alpha} \boldsymbol{\alpha}$ ) ${ }^{7}$, то есть, добавим, как некое 'умозаключение', к которому пришли посредством размышлений, построенных вспять, не только не разумно, но и крайне легкомысленно, ибо такая тактика уводит науку в область наукометрических упражнений, что наловчились из своего пулемёта стрелять именно по 'науке', к тому же, память - не единственная возможность, чтобы растормошить/встревожить сознание - умозримое чувственное восприяmue всегда бьётся у вас на ладони золотой рыбкой, мигая галактикой в спирали в действительной лаве настоящего. Заключаем, память нельзя признать основным источником мышления/осмысления, а потому она не может являться неоспоримым и единственным доказательством наличия у вас сознания.

Сознание как система для думания (мыслеговорения) вырабатывает язык осмысления для общения с самим собой, в первую очередь. Язык осмысления мира. Лишая языка - усмиряющего и вдохновляющего собственное Я, апостолы новой веры полиэтничости, однообразия и униформы лексем 'аглицкого кроя', не просто буквально вырывают язык, создав наукометричные правила для всей планеты, выдирая с корнем, как сорняк, родной язык, а вместе с ним и способность размышлять самостоятельно - то есть самостоятельно выстраивать силлогизмы и ал-

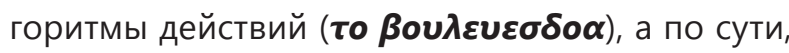
просто обесточивают человека. Вы же не учите обезьянку говорить, если это не ваша профессиональная обязанность - цирковая затея? Тогда зачем писателя, философа, филолога, хирурга (который к тому ж, привык к латыни), историка и далее заставлять крутить поясное антре перед зевающей публикой? «Я - бывают разные!»так и «просветлений»- сознающих себя сознаний (ССС) - может быть тьма тьмущая, - все дело в языке, что образами роет кротовые норы в своей головной коре и строит с их помощью силлогические пирамиды, распуская и заплетая трансгрессивные косы размышлений, как пеньковые верви, и совсем не обязательно к сиятельным ССС идут через йогу - как раз наоборот: минуя восточные изгибы медитаций, овладев языком осмысления - что для внутренних монологов и что непременно вырастает в 'письменную

7. Там же. С. 150. 
речь' - высшее достижение и достоинство Сознания (не путать с языком говорения - с банальной коммуникативной функцией); можно, и так происходит, попасть под вольту Смысла пройти сквозь 'золотые ворота' и... рассмеяться от простоты понимания. И потом, смотрите чаще по сторонам: кому это выгодно, делать вас хромым на обе ноги, протыкая сухожилия? Кому на руку непроверяемый бред, чья научность базируется на опытах с мышами, психически нездоровыми, на анализе абортируемого или разложившегося материала при калькировании чужих методик, то есть от глашатаев условно в сослагательном наклонении?

Признаем, ибо это факт, что современная философия уподобилась схоластике - из неё же она и вышла, не закрыв за собой дверь, сохранив для последней широкое поле возможностей - и та спустя столетия плющом расползлась, мимикрируя, обретая новые прозвища - постмодернизм, структурализм, трансгуманизм... - эта вечнозелёная «лужайка», приучая к безответственному и беспочвенному словоговорению (вот он Апофеоз, г. Шестов!), услужливо и заботливо мягкая, как саджада ${ }^{8}$, и удобная, словно пазлы: собрал-расчленил-сложил, - заполонила собою все мыслимые и плохо охраняемые пространства: трансцендентальные усики (что ваша традесканция) тянут свои схоластические коды к нейролингвистике, биомеханике и искусственному интеллекту - растите, детки! И на этом поле расцветают удивительные растения! Вот, например, как можно быть «алармистской» (признания сопровождаются чуть ли не постукиванием по груди) при дипломах доктора филологических и биологических наук? Это либо словесное трюкачество, либо известное чудачество на склоне лет - та унтер-офицерская вдова, что сама себя высекла, - глупость, что рассчитывает на глупость окружающих, которые выслушивают с трепетом бандерлогов лингвомазурку г. Ч-кой, впадая в коматоз от редкого в наши дни словесного говорения - буквально стилем-кролем Хлестакова: обо всем и сразу, но тем самым, гордящаяся своим «алармизмом» учёная дама, задирая отличительной пуговкой своего профессорского мундира, демонстрирует его подкладку: «впадать в панику», «вводить в заблуждение», «распространять

8. Саджада (араб., саджадат, мусалла, бисат, хасир, хумра; перс. - джайнамаз; тат. - намазлык; будд. - футон) коврик для молений, медитаций. непроверенные, необоснованные слухи, вызывающие тревожные настроения свойства» ${ }^{9}$, либо расписывается в собственном невежестве, ибо филологу не пристало не ведать значения слов, либо она из свиты Циника - не моргнув глазом объявляет о цели своего выступления: оглуплять несведущих. Это современные апостолы научной веры? Ломоносова на них нет! И Крылова. Но наш-то разум не должен спать, иль он ждёт возмущения, что доводит до кипения, а потом и за Можай? Книга Шукшина о Степане Разине называлась «Я пришел дать вам волю» - о какой «воле» шла речь? Был ли иной смысл в заглавии, кроме раскрепощения кабальных, гражданских свобод? Думается, Василий Макарович, при всей своей тяге к образности, иносказательности и парадоксальности высказывания (закаламбуриванию и игривости ума), мог иметь в виду и нечто иное - н-р, волю к осмыслению, собственному, волю единолично управлять собственным рассудком и поступками. Г-жа Профессор вам этого не обещает - наоборот, забирает волю и веру в себя, сообщая: мозг - непознаваем, глубок и своенравен - практически по-Дантевски: «Оставь надежду всяк сюда входящий!» - словом, всем спать! Быть может, сон не лучшее лекарство, и, вопреки советам медиков, иногда он "хуже керосину» ${ }^{10}$ ?

Наука, озабоченная картированием собственных плавничков, занялась редукцией вместо дедукции: препарирует лягушек из Млечного Пути, отказываясь от общего - перспектив понимания «бесконечного информационного многообразия» (Сознания), предалась увлекательной конкретике - исследует не все связи между нейронами (и то - вдруг половина окажется внебрачными?), а только такие их совокупности, активация которых соответствует единицам когнитивного опыта, а чтобы эксперименту придать уникальность, сканируют мозг рыб, мышей, кроликов и макак - уж они точно не поделятся ни $\boldsymbol{\alpha} \boldsymbol{\iota} \boldsymbol{\delta} \eta \boldsymbol{\jmath}$ (чувственным восприятием), ни чтолп廿ь (мыслью), умолчат, но кого волнует Стагирит в эру смартфонов, когда важен не Смысл, а картинка мерцающих огней, которые так увлекательно считать. Хоть одна золотая рыбка поделилась своим чувственным восприятием не червячка - холодных струй, сыграла ли на них ноктюрн?! Хоть

9. Словарь иностранных слов.-М.: Сирин, 1996. С. 25.

10. Присловье из м/ф «Волшебное кольцо» по одноимённой сказке Бориса Шергина. 
одна макака поделилась мыслью, как трудно воспитывать детей? Хоть одна крыса раскрыла свое умозримое чувственное восприятие смерти соседки/соседа по клетке пытливым исследователям «когнитома» ${ }^{11}$ ? Весь этот 'сеанс черной магии' - гипнотические этюды - можно было бы рассматривать как пляски с бубном в промозглую погоду, но используя нанотехнологии в диагностике и губительную для ДНК фармакологию, рассчитывая, видимо, на трансгенные мутации (ген новизны c-fos), можно предположить, что нацелились на человечество, которое по причине отсутствия мировых войн (локальные конфликты не в счёт) как-то прибавило в весе.

И дабы не быть голословной в рассуждениях, я всё же решила подкрепить свои мысли аргументами - не дамасской стали, не цельнолистовой - бумажной, но отыскались только материалы устных выступлений (все указываемые статьи оказались заштабелированными в закрытых PDF). Привожу фрагмент одного такого и без купюр, дабы «...ость каждого была видна», как по указу Петра I, причём я не выискивала, а стала читать первый сайт, что предложил виртуальный мир, - случилось «согласно поговорке», что, как крылатая Ника, всегда бежит на ловца, - выступления (видимо, на радио) мне оказалось довольно, чтобы убедиться, что мои финальные аккорды избрали правильную тональность - ментальным кварком, или в духе Демокрита - тревожным эйдосом, что был не сдержан на полёт, что ваш Чкалов. Для удобства чтения свой коготок о читаемом и умопостигаемом суждении г. Анохина, изобретателя «когнитома», я буду размещать следом за испытуемой на истину фразой моего оппонента - итак, мой комментарий, возникающий при чтении непосредственно вслед за восприятием (continuum), пущен в квадратных скобках и курсивом, создавая тем самым трансгрессии токи ('движение сквозь') - то самое искомое коловращение мыслительной 'материи', и таким образом читатель сможет наблюдать «работу» Сознания, так сказать 'за работой' и 'в рабочем режиме', то есть постигать мое постижение как 'умозримое восприяmue' - по Аристотелю, а не по «новозаветным» введениям к натуральному счёту бесконечного множества. Считайте это приёмом контаминации, аналогично той, с которой началось наше

11. Термин, предложенный российским нейрофизиологом К. Анохиным. погружение в «Собачье сердце», именно его использовал сам Булгаков, располагая внутренние монологи собаки Шарика - комментатора вслед за репликами персонажей-людей - словом, старейший беллетристический приём, ибо искусство призываемо нами не столько отражать все всполохи и сочленения в спиральной безделице Фибоначчи - сколько понять и принять его 'мирозданьем' - миром без границ, но в пропорциях здравого смысла — огранённой красоты, именно для тебя, тобою, для других, во благо а значит, авансом - за воплощенный Образ.

Вот слова не мальчика, но мужа ${ }^{12}$ : «Сегодня существуют методы микроскопии, позволяющие выполнять тончайшее послойное сканирование с разрешением, фиксирующим отдельные нейроны. Таким образом, имеется принципиальная возможность экспериментально вычленить нейронный ансамбль, отвечающий за элементарную единицу когнитивного опыта. Таков примерный экспериментальный план тоненьким пунктиром (лет так на 10-15 вперед) [а назад? конечно 'вперед' - не Бенджамин Батон! не иначе две жизни себе наметил!]. Теперь что мы имеем по теоретической части [разговорная речь выдаёт политрука - чисто Нагульный!]. Во-первых, как и должно, мы имеем новое понятие (эйдосЈ) — ког! [новое как хорошо забытое старое - авторские права точно никто не предъявит!] Это совокупность элементарной нейронной сети и соответствующего ей единичного когнитивного опыта. Полный набор когов в индивидуальном сознании, сформированный в процессе эволюции, развития и познания индивида называется КОГНИТОМ (это по созвучию с геномом, размах [или отмыв?] на будущее как бы просматривается). Вообще же, по своей абстрактной сути [??? а как же вы намерились ловить абстракции?] когнитом - это не что иное, как гиперсеть. Гиперсеть - это такая штука [для доктора наук очень банально: просторечие на 'определение' не тянет], в которой каждой совокупности определённым образом связанных элементов сети нижнего уровня (нейронному ансамблю) соответствует элемент верхнего уровня (ког) [ба, братцы! то ж принцип пирамиды!]. Такая объёмная единица гиперсети называется гиперсимплексом. И что примечательно,

12. Цит. текст «Станет ли когнитом золотым ключиком к тайне сознания?», представляющий собой развернутое интервью-презентацию доктора биологических наук К. Анохина в электронном журнале Эволюция, 2014, июль, 14 8:25 (вечера) [www.evoluziya.livejournal.com]. 
ансамбли нижнего уровня вполне могут перекрываться. И за счёт таких пересечений выстраиваются ассоциативные связи между когами (ага! Равно как и мыслительные цепочки у нас в голове) [не всегда чепочки - как правило, рвань! стихи не пробовали читать, чтоб понять это? чтоб уловить пересечения ассоциаций? судя по этой цитате, маленький Костя больше всего в детстве любил украшать ёлку гирляндами страсть к огонькам на различной высоте да ещё с пересечениями!]. Таким образом, коги все связываются в одну зернистую [?? видели?] структуру: и стоит активироваться одному когу, как тут же активируются все те коги, в которых есть хотя бы несколько общих с первым когом элементов [вот новость! метафора всегда на сходстве и смежноcmu paбomaem]. То есть когнитом - это не просто множество элементов, а сложно связанная совокупность [как заклинает!]. А стало быть, тут и своя непростая математика просматривается: в частности, формализм и метрика теории гиперграфов. И это замечательно, что она есть, математика! [отmого что вы сосчитаете все женские рифмы, вы поймете Шекспира? или так вы будете искать исток его гомосексуальности? счетоводы!] Ведь это значит, что развиваемая новая концепция - «когнитивистика» - формализуемая в принципе, а не просто там какая-то философия про вилы на воде [точнее не скажешь и про вилы, и про себя, родного, - сдал с потрохами! вот где вилы, так вилы - фитюлька, что, используя денотат "смысла», 'целью' его не ставит, да ещё и гордится прямым заимствованием, словно не замечая. Cognitum - понимание, а здесь восторг - фишки посчитать! помнится, в одной сказке также любили страсть как посчитать всё, что движется и пыжится, растёт и пропадает - кроты из "Дюймовочки», но те были слепые...]. В чём перспективы загадочного «чеширского» кога? А в том, что он объединяет в себе объективно-материальное (нейронную основу сознания) и субъективно-идеальное (собственно элемент сознания, единицу когнитивного опыта, ментальный квант). Т. е. вполне можно ожидать, что ког окажется тем самым недостающим звеном, стежком, который зашьёт зияющую брешь между нейрофизиологией и нейропсихологией [про Шарикова вот так же высокопарно изъяснялись], помирит мозг и психику, решит одним (а может, и не одним) махом «проклятую» психофизиологическую проблему». [Ооо!!! Боги! Где ваши уши! Проклятье? Как оно было бы к месту! Как вовремя поднесённый носовой платочек - спичкой - в непраздном деле редукции народонаселения - все прокляты! - всех в печь! Ведь они никчёмные - у них проблемы с мозгом и психикой! Причём вечные! Постойте, а психика разве не внутри мозга? Или мозг отказал ей в постое? Куда ж ей бедной податься? - не иначе как в когнитом - приютит и обогреет всей совокупностью нейронов гиперсети. На квадратный сантиметр единичного опыта - дыра понимания: «потрудитесь объяснить: кто на ком стоял?»]

Суммируем в сухом остатке: необходимость в познавании - cognuitio - как «изучение и noзнавание умом и чувствами», то есть как "осознанная необходимость» существования, вопреки ажитации самозваного термина, отпала, как собачий хвост Шарикова - оставлен COG, как атавизм и как объект 'цветных картинок', что являет томограф с анимацией, древо познания выставляя на продажу новогодней ёлкой с огоньками, что в век Цифры актуальнее считать, чем восторгаться.

Итак, ре-эволюция научного знания налицо - «наниче обороченная» - и мы с этого начали - с кромешного мира, что обернулся явью, балаганной. Стиль «собачьих реплик» соблюдён - и мы имеем результат: поистине, умопостигаемый эксперимент: числом! невидимых кварков - раскрылся “сияющей чушью» ${ }^{13}$. Вот они три составных части наимоднейшего «марксизма»: геном - коннектом (совокупность связей между отделами мозга) - когнитом (сумма элементов индивидуального опыта), где выступающий в роли «английской политэкономии» средний тип, создаёт свою «совокупность» на опыте чужих (мышки же за себя научный отчёт не напишут, «Флейту-позвоночник» не пропищат) ${ }^{14}$. А социалист-утопист когнитом как будет перемешиваться с внешним носителем (экспериментатора), как будет вливаться в его 'коннектом', совокупляясь между отделами мозга, что мнит себя Наполеоном? Смешение будет проводить чревовещатель-ницшеанец? Коннектокопатели ${ }^{15}$

13. Высказывание Преображенского о штиблетах Шарикова («Собачье сердце» М. Булгакова)

14. Три источника и три узловых центра марксизма — это «немецкая философия, английская политическая экономия, французский социализм» [Ленин В.И. Три источника и три составных части марксизма. Полн. собр. соч. Т. 23].

15. Коннектом - совокупность всех связей в мозгу, термин, введённый в 2005 г. Олафом Споринсом, Джулио Тонони и Рольфом Кёттером (Фогтонский инс-т исслед. мозга 
вспомнили (памятью воспаляясь) забытые эйдосы греков, что обеспечивали бег Энтелехии, но облатку взяли латинскую, привычную для про-

в Дюссельдорфе) [«PLoS Computation Biology», 2005, 1 (4), р. 42] - то есть коллективный такой эмбрион. В том же году Патрик Хагман использует то же слово в тезисах своей кандидатской диссертации, называя так «совокупность всех связей в нём как единое». Думается, что такое «единение» мыслей стало по причине знания латыни или просто родного для них языка, что сформировался на её базе, войдя в романо-германскую семью индо-европейской группы языков: connecto, nexui, nexum - 1) связывать, сплетать, заплесть, посредством связывания, сплетания; 2) соединять - непосредственно присоединять во времени, составлять из частей [Латинско-русский словарь / О. А. Петрученко. - Репринт 9-го издания 1914 г.— М.: Эксмо, 2017.C. 127]. изношения - аглицкий крой, что популярен по необходимости или предполагаемой выгоде по Цезарю.

\section{БИБЛИОГРАФИЯ}

1. Aristotelis fragmenta selecta / Recognovit W.D. Ross. Oxford, 1955. Цитаты приводятся по русскому переводу: Аристотель. Протрептик. О чувственном восприятии. О памяти. / Пер. на рус. Е. В. Алымовой.СПб.: Изд-во С.- Петербургского ун-та. 2004. - 183 с.

2. Античные теории языка и стиля / Под общей редакцией О.М. Фрейденберг. - Москва Ленинград: Государственное социальноэкономическое изд-во, 1936. - 343 с.

3. Барт Ролан. S/Z. - М.: Эдиториал УРСC, 2011.232 c.

4. Гелий Авл. Аттические ночи. Книги I-X / Пер. с латинского под общ. ред. А.Я. Тыжова.-СПБ.: ИЦ «Гуманитарная Академия», 2007.- 480 с.

5. Гомер. Одиссея / Пер. с древнегреч. В. Жуковского. Песнь XXII [St. 295, St. 306-309]. - М.: Правда, 1984.- С. 272.

6. Греческие эпиграммы (VII век до н.э.- IX век н.э.) / Перевод, статья и примечания Л.В. Блуменау.Москва - Ленинград: ACADEMIA, 1935.- С. 316.

7. Греческо-русский словарь, составленный А.Д. Вейсманомъ. - С.-Петербургъ, 1899. Репринт V изд.- М.: Греко-латинский кабинет Ю.А. Шичалина, 2011.

8. Ингарден Роман. Очерки по философии литературы. - Благовещенск: БГК им. И. А. Бодуэна де Куртенэ, 1999. - 184 с.

9. Краткий словарь латинских слов, сокращений и выражений / Сост. В. Купреянова, Н. Умнова. М.: TEPPA, 1996.- С. 75.

10. Кулаковский Ю.А. Эсхатология и эпикуреизм в античном мире.- СПб.: Алетейя, 2002. - 256 с.

11. Латинско-русский словарь / О.А. Петрученко.Репринт 9-го издания 1914 г.- М.: Эксмо, 2017.

12. Лингвистический энциклопедический словарь.М., 1990.- С. 584.

13. Лосев А.Ф. Высший синтез. Неизвестный Лосев.М.: ЧeРo, 2005.- 264 c.
14. Мамардашвили М.К. Введение в философию // Необходимость себя.- М., 1996. - С. 130.

15. Меньшикова E. P. Double axe Мифа (дифтонг зонга): Забытая флейта греческой эпиграммы / Оправдание подлости, или Тотальная трансформация «по Фаренгейту» (парадокс циника). Ч. I // Дом Бурганова. Пространство культуры. - 2020.№ 3.- C. 21-46.

16. Меньшикова Е.Р. К проблеме интерпретаций неологизма «утопия» / Античность как геном европейской и российской культуры.- СПб.: Алетейя, 2016.- С. 237-282.

17. Меньшикова Е.Р. Миф как натуральный обмен (гносеологические аспекты практической лжи) // CredoNew. - 2017. - № 1-3.

18. Меньшикова Е. Р. Натуральный ландшафт философии (политическая рефлексия Гераклита и Аристотеля) // Дом Бурганова. Пространство культуры. - 2019. - № 4; 2020. — № 1.

19. Меньшикова Е. Р. Рецептивное проклятие или терминологический сбой: к проблеме интерпретаций неологизма Т. Мора «утопия» // CredoNew. - 2012. - № 3-4.

20. Меньшикова Е.Р. Рондо Мифа: «Троянский терроризм» как идея исключительности, или Summum bonum Цезаря: насильем покоряйте мир! // CredoNew. - 2019. - № 2.

21. Меньшикова Е.Р. Троянский терроризм как принципат Обмана, или В объятиях терракотовой саранчи (этимологические надкрылья virtus). 4. 1-3 // CredoNew. - 2018. - № 3-4. - 2019. — № 1.

22. Меньшикова Е.Р. Троянский терроризм как установленный порядок (disciplina), или Кочующий колонат (миссия Мифа в пространстве Т. Мора «Утопия») // CredoNew. - 2018. - № 2.

23. Меньшикова Е.Р. Троянский терроризм: условие эволюции или месть колонистов? (к проблеме «свой/Чужой») // CredoNew. - 2018. - № 1. 
24. Menshikova E.R. «Utopia: Reseptive curse or terminological failure - The problem of interpreting the Thomas More's neologism of utopia» / XXIII World Congress of Philosophy «Philosophy as Inquiry and Way of Life». Abstracts. - Athens 04-10. August 2013. University of Athens, School of Philosophy University Campus - Zografas.

25. Menshikova E.R. The natural landscape of philosophy (political reflaction of Heraclitus and Aristotle) // $29^{\text {th }}$ International Conference of Philosophy «Greek moral and political philosophy-From Pre-Socratics to Neo-Platonism» (July 7-11, 2017, Rhodes). Paper Abstracts. - Rhodes, 2017.

26. Menshikova E. R. The Natural Landscape of Philosophy (The Political Reflection of Heraclitus and Aristotle) // Philosophy Study, Volume 8, Number 1, 2018.

27. Menshikova E. R. The Troyan Terrorism as an Established Order (Disciplina), or the Nomadic Colonatus (Mission of Mith in the space of Sir Thomas More's «Utopia») // International Relations and Diplomacy, February 2018, Volume 6, Number 2 (Serial Number 53).

28. Menshikova E.R. The Trojan Terrorism: Revenge Colonists or Condition of Evolution? (To the Problem «Your/ Alien») // Philosophy Study, V. 8, N. 4, 2018.

29. Панофски Эрвин. IDEA: к истории понятия в теориях искусства от античности до классицизма. - СПб.: Андрей Наследников, 2002. - 237 с.

30. Пёльман Роберт фон. Очерк греческой истории и источниковедения / Пер. с нем. А.С. Князькова; под ред. проф. С.А. Жебелева / Научн. ред.4-го издания 1910 г.- СПб.: Алетейя, 1999. - 471 с.

31. Плутарх. Сочинения / Пер. с древнегреч. Т. Г. Сидаша. - СПб.: Изд-во С.- Петербургского унта, 2008. - 384 c.
32. Пятигорский Александр. Что такое политическая философия (цикл лекций).- М.: Издательство «Европа», 2007.

33. Рикёр Поль. Конфликт интерпретаций. Очерки о герменевтике / Пер. и вступит. ст. И. Вдовиной. М.: КАНОН-пресс-Ц; Кучково поле, 2002. - 624 с.

34. Словарь иностранных слов / 7-е научно-редакт. переработ. изд.- М.: Сирин, 1996.- 608 с.

35. Феофраст. Характеры / Пер., статья и прим. Г.А. Стратановского. Репринт изд. 1974. - М.: НАУКА, 2007. - 124 с. Фрейденберг О.М.Образ и понятие / О.М. Фрейденберг Миф и литература древности.М.: Изд. фирма «Восточная литература» РАН, 1998. С. 223-622.

36. Фрейденберг О.М. «Характеры» Теофраста // Учёные записки ЛгУ. - № 63.- (Сер. филол. наук, 1941. - Вып. 7).- С. 129-141.

37. Фукидид. История / Пер. Ф.Г. Мищенко и С.А. Жебелева; под ред. Э.Д. Фролова.- СПб.: НАУКА; ЮВЕНТА, 1999.

38. Цезарь Гай Юлий. Записки о войне с галлами. Книги вторая, третья и четвертая. С введением и комментариями С.И. Соболевского. - [М.: Издательство литературы на иностранных языках, 1946]. - М.: Русский фонд содействия образованию и науке, 2011 / Неадаптированный текст <C. Julii Caesaris. Liber Secundus. XII (1)>.

39. Широков О.С. Языковедение: введение в науку о языках. - М.: Добросвет, 2003.- C. 126. Shirokov O.S. Linguistics: an introduction to the science of languages. - M.: «Dobrosvet», 2003. - P. 126. 
Xiang Wu

Postgraduate student of chair for

Monumental Decorative Sculpture

Moscow State Stroganov Academy of Design and Applied Arts

e-mail: 270283983@qq.com

China

\section{CULTURAL BACKGROUND OF CARVED STONE SCULPTURE OF ANCIENT CHINESE MAUSOLEUMS}

Summary: The article explores the ideas, characteristic for religious mindset and philosophy of Confucianism (儒 家思想)，about spiritual immortality, filial piety and ethics, which have been firmly established in funerary culture.

Harmonic balance of Confucianism, Daoism（道教） and Buddhism brought forth the ideology and concept of immortal soul, according to which the soul does not die after person's death, and the tomb is its dwelling place. Thus, the construction of tombs gained great significance.

The author analyzes Confucian idea of 'filial piety', which, merging with ritual funeral concept, developed into a concept of 'meticulous following of funerary rituals, mourning of parents and worship of ancestors' (慎终 追远), where the main emphasis is on the organization of parents' funeral, devotion to ancestors and diligent care of their remains. Furthermore, as Ancient China was an agricultural society which was deliberately devoted to earth, it was believed that the earth is crucial for survival, and one can only rest after death if one's body is committed to earth. So, to show filial affection, properly make sacrifices, pray for protection, protect the remains and ensure eternal peaceful rest, the internment in the ground became an obligatory condition. And various funeral ar-

The concept of funeral culture refers to a person's ideas about death, combinations of funeral rituals and sacrificial rites formed under the influence of the spirit of the era, philosophical and religious consciousness, and possessing a rich cultural content. A kind of portrait of the era, it had a profound impact on the life of society and individuals. In the course of formation and development of the funeral tradition, it absorbed the religious ideas of the immortal soul and the Confucian concept of devotion to parents expressed, among other things, in 'meticulous following of funerary rituals, mourning of parents and commemoration rituals for ancestors long dead' ${ }^{1}$. All this formed into

1. Lun Yu (505-435 BC). Author: Students of Confucius / Translation and commentary: Chen Xiaofen. China Publishing House, rangements, such as marking the grave, its decoration, etc., gradually transformed into funerary plastic art. Consequently, burial in the ground allowed for the possibility and resources to form the funerary plastic art.

Ceremonial ideas presented by Mencius（孟子） have become firmly established in the concept of funeral. In a feudal society, for the convenience of government and maintaining the stability of society, etiquette, contributing to the systematization of the hierarchical order of all strata of society, as well as extreme admiration for the imperial power, became a powerful ideological weapon of the rulers. In this ideology, sculptures in the tombs of the supreme rulers - emperors and wangs - are not only guards protecting from evil, but to a greater extent they are also a symbol of imperial power. Therefore, the themes, the number and the size of the sculptures in the tombs of the emperors and wangs were of the highest importance. There is also a strict hierarchical order in the sculptures in front of the tombs of government officials of various levels. Thus, etiquette established standards and order in burial plastic art.

Keywords: mausoleum carved stone sculpture, spiritual immortality, filial piety, etiquette, luxurious funeral (厚葬).

magnificent, rich in content, ideological system with ideas of etiquette and filial piety as its core concepts.

The Confucian ideology of 'observance of funerary rituals and worship of ancestors' (慎终追远) implies following the rites of burial of parents, and rituals dedicated to the remembrance of ancestors. These are the integral part of 'filial piety' standards, which is rooted in the tradition of worship of ancestors in primitive society. The work that settled the foundation of Confucian morals was the Zhou 'Book of Etiquette' (周礼) (or The Rites of Zhou) ${ }^{2}$. It

2016., p. 32 (《论语》孔子的学生记录整理.陈晓芬译注.中华 书局.2016.01).

2. 'Book of etiquette' / Translation and notes: Xu Zhengying, Chang Peiyu. Beijing: China Publishing House, 2016, p. 62 (《周礼》徐正英, 常佩雨译注. 中华书局). 
explores the notion of 'etiquette and music' (礼乐) ${ }^{3}$ as the values, inherent in civilized state and society.

The central part of Lun Yu (论语) 'Conversations and Judgements' - the principal work of Confucianism - is occupied by the passage about 'devotion to parents and elder brothers', which is an example of ethics in Confucian society. Confucius ${ }^{4}$ said 'that one must honor his parents, respect elder brothers, be cautious, and have the skills to maintain the trust of others, to care for everyone, but make close friends only with the worthiest' ${ }^{5}$. Confucius emphasized not only the material manifestations of filial piety. Emotional sincerity was much more important for him. These particular principles served as the foundation for the formation of funerary culture and system of funeral rites.

Confucian ideology is one of the cornerstones of Ancient Chinese culture which has a profound effect on the culture of China up to the present time. In turn, the concept of 'filial piety' is the basis of Confucian ideology. The introduction of Buddhism into China during Han era ensued in the active spread of religious consciousness, still the philosophy of Confucianism remained the essential school of thought. The feudal system, which prevailed for two millennia, managed to accept and assimilate the concepts of the Buddhist teachings. Nevertheless, the new religion introduced the idea of the immortal soul, which had a significant effect on the development of funeral culture. Belief in the afterlife, or the rebirth of the soul in a parallel world, gave rise to the idea of creating the 'soul abode' where the souls of the dead could continue to exist. All this led to the introduction of luxurious funeral rites accompanied by prolonged mourning. Thus, the funeral tradition of ancient China absorbed the Confucian ideology of 'filial piety' and the religious faith in the immortality of the soul.

Emperors occupied the highest position in the Ancient Chinese feudal society; respectively, it was them who possessed the economic power, which made it possible to build the most luxurious tombs and fully materialize the idea of the 'afterlife' in the funeral ritual. The tombs of the emperors demon-

3. 'Etiquette and Music' (礼乐): 'Etiquette and Music' are called upon to cultivate moral integrity, modesty and tact in a person, to regulate the norms of behavior in various layers of society.

4. Confucius (孔夫子) (Kong Zi. 28.09.551-11.04.479 BC).

5. Lun Yu (505-435 BC). Author: Students of Confucius / Translation and commentary: Chen Xiaofen. China Publishing House, 2016., p. 22 (《论语》孔子的学生记录整理. 陈晓芬译注. 中华 书局.2016.01). strated the most perfect examples of funeral architecture and plastic art. It is here that the carved stone sculpture is born, pleading to pray for happiness, to resist evil spirits, to protect the emperor in his new life.

The ideology of 'meticulous following of funerary rituals, mourning of parents and commemoration rituals for deceased ancestors' (慎终追远) included the following:

'Luxurious funeral' (厚葬), which implied conducting a solemn funeral rite, rituals of sacrifice and long-term mourning for the deceased. Burial in the ground was the best solution to these requirements, since it implied rich funeral ceremonial, allowed for extended preservation of the remains and at the same time provided a permanent location for prayers.

Treating the dead 'after death as when they were alive' $^{6}$ (事死如生). The tradition, formed under the influence of the immortal soul ideology of Buddhism and filial piety of Confucianism, was to supply the deceased with everything he had used when he was alive. Architectural buildings, funerary items, as well as carved stone sculptures that serve as guards, servants, etc. appear in the mausoleums ${ }^{7}$.

'Prayers for wellbeing in the afterlife' (祈求冥福), demonstrating care for the soul of the deceased, and wishing him happiness and tranquility in the afterlife. They are associated with the emergence of the Feng Shui teachings, which guided the choice of a place for a tomb, the choice of sculptures designed to resist evil spirits; the formation of the tradition of visiting the grave of ancestors and sacrificing specially prepared fake money (the sacrifice performed in front of the grave was a ceremony of burning various items made of paper which imitated real-life objects such as money, houses, clothes, etc.), the tradition of donating fresh food, etc.

In the history of China, various methods of burial were used, including cremation, open-air burial, burial in water, hanging, burial in the ground, etc. Herewith, the burial in the ground the was best way to fulfill the requirements for the preservation of corpse along with the funeral inventory; and, consequently, to comply with Confucian etiquette as well.

There are three main reasons for the spread of burials in the ground:

6. Zisi. Zhong Yong. Beijing: China Publishing House, 2006., p. 12 (子思《中庸》中国图书出版社，北京，2006.10).

7. Wang Jisheng. Death is Life: Funeral Ethics and Chinese Culture. Shanghai: Baijia Publishing House, 2001, p. 96 (王计生.《事死 如生: 殡葬伦理和中国文化》上海. 百家出版社.2002.01). 
Burial in the ground allows for better preservation of the remains, albeit not for a very long period of time. Walls of coffin and a layer of soil protected them from the effects of unfavorable weather conditions and harm caused by wild animals, ensured the best possible level of preservation, and created the feeling of 'home', sheltering the deceased from wind and rain.

Burial in the ground means that a certain location must be designated for the rituals of commemoration and mourning of the deceased. Confucian morality demanded the descendants to provide the deceased with a rich life after death. This led to the appearance of various burial equipment designed to satisfy the needs of the soul in a parallel world, and to the emergence of the tradition of sacrifices on the celebration of Qingming (清明节)， a holiday of commemoration of the dead, when descendants burned paper money and household items on the ancestor's grave.

Burial in the ground is inextricably linked with the concepts of 'finding the eternal peace for the soul' (入土为安) (burial in the ground was an essential condition for the soul to find an eternal abode) and 'the unity of Heaven and man' (天人合一). These concepts reflected the affection for the land and admiration for nature in the ancient Chinese.

Thus, the ideology of funeral culture had the decisive role in the choice of burial methods. The emergence of the burial in the ground ritual paved the way for the development of burial architecture, and, as a result, for the development of carved stone sculpture in burial complexes.

\section{'Norms of morality' and luxurious funeral in Confucian ideology}

The 'norms of morality' (厚葬) meant the observance of behavioral and moral norms, strictly regulated for each of the social classes and affecting all aspects of human life.

Mencius (孟子) ${ }^{8}-a$ follower of Confucius - is one of the quintessential representatives of Confu-

8. Mencius (孟子) (372-289 BC) - one of the representatives of Confucian philosophy of the Warring States period. cian philosophy who influenced the development of the burial culture in Ancient China. During his time the concept of 'filial piety' was supplemented by the concept of 'etiquette' (礼), which included such components as the ceremonial, moral norms and hierarchy, and became one of the main pillars of the funerary culture, along with 'filial piety'. Thanks to Mencius, the concepts of 'etiquette' and 'filial piety' (孝) were firmly established in the funerary tradition of Ancient China 9.

The idea of 'etiquette', actively promoted by Mencius in the funerary culture and the life of society as a whole, ideally corresponded to the aspirations of the ruling strata. From the funerary tradition point of view, it was expressed mainly in strict subordination, implying that the higher the status of the deceased, the higher was the status assigned to his tomb. This approach allowed for the systematization of the canons of funerary architecture and sculpture.

Taking into account the above, the funerary tradition, which incorporated the ideas of 'etiquette' ( 礼), 'filial piety' and belief in the immortality of the soul, served as a stimulus for the development of funerary architecture and plastic arts, created all the prerequisites for the flourishing of funerary art, and, at the same time, it contributed to the regulation of the behavior of representatives of different social classes, the formation of a standardized, systemic code for each of the strata. The highest position in the society was occupied by the emperor. The imperial tombs were distinguished by special grandeur, the funeral rites were characterized by complexity and luxury. It was the imperial tombs that revealed to us the funerary culture in its entirety and at the same time demonstrated the power of centralized power in feudal China. The carved stone sculpture, which is a symbol of social differentiation and designed to resist evil spirits as well, call out to heaven with prayers, protect the peace of the owner of the mausoleum, gradually becomes an integral part of the burial complex.

9. Fan Yong. Mencius. Beijing: China Publishing House, 2017, p. 42 (方勇译注《孟子》. 中华书局.2017.12). 


\section{REFERENCES}

1. Dong Xinlin. 2005. Archaeological research in ancient Chinese mausoleums.- Xiamen: People's Publishing House of Fujian province, p. 87 (董新林 《中国古代陵墓考古研 究》. 福建人民出版社, 2005年).

2. 'Book of Etiquette' / Translation and notes: Xu Zhengying, Chang Peiyu. Beijing: China Publishing House, 2014, p. 62 (《周礼》徐正英, 常佩雨译注. 中华书 局.2014.02).

3. Yang Kuan. 2003. A Study of the History of the Development of Tombs in Ancient China. Shanghai: People's Publishing House, p. 112 (《中国古代陵寝制度史研究》 杨宽. 上海人民出版. 2003).

4. Fan Yong. 2017. Mencius. - Beijing: China Publishing House, p. 42 (方勇译注 《孟子》.中华书局.2017.12).

5. Wang Jisheng. 2001. Death is Life: Funeral Ethics and Chinese Culture.- Shanghai: Baijia Publishing House, p. 96 (王计生. 《事死如生: 殡葬伦理和中国文化》 上海. 百家出版社. 2002.01).
6. Yang Kuan. 2010. Mausoleums in Ancient China.Nankai University Press (杨宽: 《中国古代陵墓》. 南开大学 出版社.2010.5.1).

7. 罗开平: 《中国墓葬 文化》. 海南人民出版社.1998. Luo Kaiping. Chinese Tomb Culture.- Hainan: Hainan People's Publishing House, 1998.

8. 黄忓华: 《中国佛教史》. 吉林人民出版社.2013. Huang Chanhua. History of Chinese Buddhism. Changchun: Jilin People's Publishing House, 2013.

9. Wang Luyu. 1989. Chronicle of Chinese Sculpture.Beijing: Xueyuan Publishing House, 1989 (王鲁豫: 《中国雕塑史册》. 北京, 学苑出版社.1989).

10. Feng Yulan. 2013. Brief History of Chinese Literature.-Beijing: Beijing University Press（冯友兰: 《中国哲学》. 北京: 北京大学出版社). 


\section{КУЛЬТУРНЫЕ ПРЕДПОСЫЛКИ К ФОРМИРОВАНИЮ КАМЕННОЙ РЕЗНОЙ СКУЛЬПТУРЫ В ДРЕВНЕКИТАЙСКИХ МАВЗОЛЕЯХ}

Аннотация. Аннотация: В статье исследованы характерные для религиозного сознания и философии Конфуцианства (儒家思想) идеи о бессмертности духа, сыновней почтительности, этикете, которые прочно вошли в погребальную культуру.

Гармоничное сочетание конфуцианства, даосизма (道教), буддизма породило идеологию и концепцию бессмертия души, согласно которой душа и после смерти человека не умирает, а гробница - это место её обитания. Поэтому строительству гробниц придаётся большая важность.

Автор анализирует конфуцианскую идею сыновней почтительности, которая слившись с ритуальной концепцией похорон, развилась в концепцию «тщательного соблюдения погребальных обрядов и траура по родителям, почитания предков» (慎终追远), где основной упор делается на организации похорон родителей, ревностном поклонении предкам, тщательном уходе за останками. Помимо этого, так как в древности Китай как аграрное общество отличался ярко выраженной привязанностью к земле, считалось, что человек выживает благодаря земле, а после смерти может спокойно отдохнуть, только если предать его тело земле. Поэтому для выражения сыновней любви, удобства жертвоприношений, моления о покровительстве, защиты останков усопшего, обеспечения вечного покоя умершего погребение в земле стало обязательным

Под понятием погребальной культуры подразумеваются представления человека о смерти, комплексы похоронных обрядов и ритуалов жертвоприношений, сложившиеся под влиянием духа эпохи, философского и религиозного сознания и обладающие богатым культурным содержанием. Это своеобразный портрет эпохи, оказывающий глубочайшее влияние на жизнь общества и человека. На протяжении своего становления и развития погребальный культ впитал условием. А различные погребальные мероприятия, такие как обозначение местонахождения, украшение и другие, постепенно трансформировались в погребальную пластику. Таким образом, погребение в земле обеспечило возможности и материальную базу для формирования погребальной пластики.

Идеи этикета, представляемые Мэн-цзы (孟子), прочно вошли в концепцию похорон. В феодальном обществе для удобства правления и поддержания стабильности общества этикет, способствующий систематизации иерархического порядка всех слоёв общества, а также безграничному преклонению перед императорской властью, стал мощным идеологическим оружием правителей. При такой идеологии скульптуры в гробницах верховных правителей - императоров и ванов - являются не только стражниками, защищающими от злых сил, но и в большей степени также являются символом императорской власти. Поэтому сюжеты, количество, размеры скульптур в гробницах императоров и ванов считались наивысшим разрядом. В скульптурах перед гробницами чиновников различных уровней также наблюдается строгий иерархический порядок. Таким образом, этикетом были установлены нормы и порядок в погребальной пластике.

Ключевые слова: каменная резная скульптура в мавзолее, бессмертие духа, сыновняя почтительность, этикет, «пышные» похороны (厚葬).

в себя религиозные идеи бессмертия души и конфуцианскую концепцию преданности родителям, выражаемую в том числе и в «тщательном соблюдении похоронных обрядов и траура по родителям и ритуалов поминовения давно ушедших предков» ${ }^{1}$. Таким образом сформировалась

1. «Лунь Юй» (505-435 гг. до н.э.). Автор: учени ки Конфуция / Перевод и комментарии: Чэнь Сяофэнь. Китайское книгоиздательство, 2016. С. 32 (《论语》孔子的学生记录整理.陈晓芬译注.中华书局.2016.01) 
грандиозная, богатая по своему содержанию идеологическая система, центральными понятиями которой явились идеи «этикета» и «сыновней почтительности».

Под конфуцианской идеологией «соблюдения погребальных обрядов и ритуалов почтения предков» (慎终追远) подразумевается соблюдение обрядов захоронения родителей и ритуалов, посвящённых памяти предков, являющихся составной частью «норм сыновней почтительности» и уходящих своими корнями в традиции почитания предков в первобытном обществе. Знаковым произведением, закрепившим основы конфуцианской морали, явилась «Книга этикета» эпохи Чжоу (周礼) (или «Чжоуские ритуалы») 2, раскрывающая понятие «этикета и музыки» (礼 乐) ${ }^{3}$ как ценностей, присущих цивилизованному государству и обществу.

В главном произведении конфуцианства «Лунь Юй» (论语) «Беседы и Суждения» центральное место занимает часть текста, повествующая о «преданности родителям и старшим братьям», являющая собой образец нравственности в конфуцианском обществе. Конфуций ${ }^{4}$ говорил о «необходимости почитания родителей, уважения к старшим братьям, осторожности, умения сберечь доверие окружающих, умения любить всех, но сближаться только с достойнейшими» ${ }^{5}$. Конфуций акцентировал внимание не только на материальных проявлениях сыновней почтительности. Гораздо важнее для него было соблюдение душевной искренности. Именно эти принципы и послужили фундаментом для формирования погребальной культуры и системы похоронных обрядов.

Конфуцианская идеология - один из краеугольных камней древнекитайской культуры, оказывающий глубочайшее влияние на культуру Китая вплоть до настоящего времени. В свою очередь основой конфуцианской идеологии является идея «сыновней почтительности». Проникновение в Китай в эпоху Хань философии буддизма повлекло

2. «Книга этикета» / Перевод и примечания: Сюй Чжэнъин, Чан Пэйюй. Пекин: Китайское книгоиздательство, 2014 C. 62 (《周礼》徐正英, 常佩雨译注.中华书局).

3. «Этикет и музыка» (礼乐) : «Этикет и музыка» призваны развивать в человеке моральную целостность, скромность и тактичность, регламентировать нормы поведения разных слоёв общества.

4. Конфуций (孔夫子) (Кун-цзы. 28.09.551-11.04.479 г. до н.э.).

5. «Лунь Юй» (505-435 гг. до н.э.). Автор: ученики Конфуция / Перевод и комментарии: Чэнь Сяофэнь. Китайское книгоиздательство, 2016. С. 22 (《论语》孔子的学生记录整理.陈晓芬译注.中华书局.2016.01) за собой активное распространение религиозного сознания, но основополагающим учением по-прежнему оставалась философия конфуцианства. Феодальный строй, господствующий на протяжении двух тысячелетий, сумел принять и ассимилировать основы буддийского учения. Тем не менее новая религия принесла с собой идею бессмертия души, оказавшую значительное влияние на развитие погребальной культуры. Вера в продолжение жизни, либо перерождение души в параллельном мире, породила идею создания «обители души», где души усопших могли бы продолжать своё существование. Всё это привело к появлению пышных погребальных обрядов, сопровождаемых длительным трауром. Таким образом погребальный культ Древнего Китая вобрал в себя конфуцианскую идеологию «сыновней почтительности» и религиозную веру в бессмертие души.

Высшее положение в древнекитайском феодальном обществе занимали императоры, и соответственно именно они обладали экономической мощью, позволявшей возводить наиболее роскошные гробницы, наиболее полно претворять идею «жизни после смерти» в погребальном ритуале. Гробницы императоров демонстрировали наиболее совершенные образцы погребальной архитектуры и пластики. Именно здесь и зарождается каменная резная скульптура, призванная молить о счастье, противостоять злым духам, охранять императора в его новой жизни.

Идеология «тщательного соблюдения похоронных ритуалов и траура по родителям и обрядов поминовения ушедших предков» (慎终追远) включала в себя следующее содержание:

«Пышные похороны» (厚葬), подразумевавшие проведение торжественного погребального обряда, ритуалов жертвоприношений и долгосрочный траур по усопшим. Погребение в земле лучшим образом отвечало данным требованиям, так как подразумевало богатый погребальный церемониал, позволяло на протяжении длительного времени сохранять останки усопшего и в то же время предоставляло постоянное место для молитв.

Отношение к усопшему «после смерти, как при жизни» (事死如生) ${ }^{6}$. Под влиянием буддистской идеологии бессмертия душ и конфуцианской идеологии сыновней почтительности сложилась традиция снабжения усопшего всем необходимым,

6. Зиси. Чжун Юн. Пекин: Китайское книгоиздательство, 2006. C. 12 (子思《中庸》中国图书出版社，北京，2006.10). 
чем он пользовался при жизни. В мавзолеях появляются архитектурные постройки, погребальный инвентарь, а также каменные резные скульптуры, выполняющие функции охраны, прислуги и пр ${ }^{7}$.

«Молитвы о потустороннем благополучии» (祈求冥福), демонстрирующие заботу о душе усопшего, пожелания ему счастья и спокойствия в загробном мире. С ними связывают появление учения Фэншуй, которым руководствовались при выборе места для гробницы, скульптур, призванных противостоять злым духам, формирование традиции посещения могилы предков и приношения в жертву специально подготовленных бутафорских денег (жертвоприношение представляло собой церемонию сжигания перед могилой бумажных принадлежностей, имитирующих объекты реальной жизни, включая деньги, дома, одежду и пр.), традиции принесения в дар свежей пищи и пр.

В истории Китая имели место различные способы погребения, среди которых кремация, похороны под открытым небом, погребение в воде, подвешивание, погребение в земле и пр. При этом погребение в земле наилучшим образом отвечает требованиям к сохранности тела и захороненного вместе с ним погребального инвентаря, а следовательно, и конфуцианскому этикету.

Выделяют три основные причины распространения захоронений в земле:

Захоронение в земле позволяет в лучшей степени сохранить останки, пусть и не на долгий период времени. Наличие гроба и слоя почвы уберегает их от воздействия неблагоприятных погодных условий, опасности со стороны диких зверей, обеспечивает наилучшую сохранность, создаёт ощущение "дома», укрывающего покойного от дождей и ветров.

Захоронение в земле подразумевает обозначение чёткого местоположения для совершения обрядов поминовения и оплакивания усопшего. Конфуцианская мораль требовала от потомков обеспечить усопшему богатую жизнь после смерти. Это привело к появлению разнообразного погребального инвентаря, призванного удовлетворять потребности души в параллельном мире, а также формированию традиции жертвоприношений по случаю праздника поминовения

7. Ван Цзишэн. При смерти как при жизни: похоронная этика и культура Китая. Шанхай: Издательство «Байцзя», 2001. C. 96 (王计生. 《事死如生: 殡葬伦理和中国文化》上海.百 家出版社.2002.01) усопших Цинмин (清明节), когда потомки сжигали на могиле предка бумажные деньги и предметы быта.

Захоронение в земле неразрывно связано с понятиями «обретения душой вечного покоя» (入土为安) (захоронение в земле являлось неотъемлемым условием обретения душой вечного пристанища) и «единства Неба и человека» (天人合一) 8 . В этих понятиях отразилась любовь древних китайцев к земле, преклонение перед природой.

Таким образом, идеология погребальной культуры играла решающую роль в выборе способа погребения. Появление обряда захоронения в земле открыло просторы для развития погребальной архитектуры, и, как следствие, и для развития каменной резной скульптуры в погребальных комплексах.

\section{«Нормы морали» и пышные похороны в конфуцианской идеологии}

Под «нормами морали» (厚葬) подразумевалось соблюдение поведенческих и нравственных норм, строго регламентированных для каждого из социальных классов и затрагивающих все стороны человеческой жизни.

Мэн-цзы (孟子) ${ }^{9}$ - последователь Конфуция, один из ярчайших представителей конфуцианской философии, при котором погребальная культура Древнего Китая получила своё дальнейшее развитие. При нём концепция «сыновней почтительности» была дополнена понятием «этикета» (礼)， включающим в себя такие составляющие, как церемониал, нравственные нормы, иерархия, и ставшим одним из основных столпов погребальной культуры, наряду с «сыновней почтительностью». Благодаря Мэн-цзы понятия «этикета» и «сыновней почтительности» (孝) прочно укрепляются в погребальном культе Древнего Китая ${ }^{10}$

Идея «этикета», активно продвигаемая Мэнцзы в погребальной культуре и жизни социума в целом, идеальным образом соответствовала стремлениям правящих слоёв. С точки зрения погребального культа она выразилась главным образом в строгой субординации, подразумевающей, что чем более высок статус усопшего,

8. «Единство Неба и человека» (天人合一) - философская концепция, стремление к гармоничному сосуществованию человека и неба, где человек и природа сливаются воедино и оказывают взаимное влияние друг на друга.

9. Мэн-цзы (孟子) (372-289 гг. до н.э.) - один из представителей конфуцианской философии периода Сражающихся царств.

10. Фан Юн. Мэн-цзы. Пекин: Китайское книгоиздательство, 2017. C. 42 (方勇译注《孟子》. 中华书局.2017.12) 
тем более высокий статус присваивался его гробнице. Такой подход позволил систематизировать каноны погребальной архитектуры и скульптуры.

Принимая во внимание вышеизложенное, погребальный культ, вобравший в себя идеи «этикета» (礼), «сыновней почтительности» и веру в бессмертие души, послужил стимулом к развитию погребальной архитектуры и пластики, создал все предпосылки для расцвета погребального искусства, и в то же время способствовал регламентации поведения представителей разных социальных классов, формированию стандартизированного, системного кодекса для каждого из слоёв. Высшее положение в обществе зани- мал император. Императорские гробницы отличались особой величественностью, похоронным обрядам были присущи сложность и пышность. Именно императорские гробницы явили нам погребальную культуру во всей её полноте и в то же время продемонстрировали мощь централизованной власти в феодальном Китае. Каменная резная скульптура, являющая собой символ социальной дифференциации, а также призванная оказывать противостояние злым духам, взывать с молитвами к небу, защищать покой хозяина мавзолея, постепенно становится неотъемлемым элементом погребального комплекса.

\section{БИБЛИОГРАФИЯ}

1. Дун Синьлинь. Археологические исследования в древнекитайских мавзолеях. - Сямэнь: Народное издательство пров. Фуцзянь, 2005.C. 87 (董新林 《中国古代陵墓考古研究》. 福建人 民出版社，2005年).

2. Книга этикета / Перевод и примечания: Сюй Чжэнъин, Чан Пэйюй.- Пекин: Китайское книгоиздательство, 2014.- С. 62 (《周礼》 徐正 英, 常佩雨译注.中华书局.2014.02).

3. Ян Куань. Исследование истории развития гробниц в Древнем Китае.- Шанхай: Народное издательство, 2003.- С. 112 (《中国古代陵寝制度史研究》 杨宽. 上海人民出 版社. 2003).

4. Фан Юн. Мэн-цзы. - Пекин: Китайское книгоиздательство, 2017.—C. 42 (方勇译注 《孟子》. 中华书局.2017.12.).

5. Ван Цзишэн. После смерти, как при жизни: похоронная этика и культура Китая. - Шанхай: Издательство «Байцзя», 2001.- С. 96 (王计
生. 《事死如生: 殡葬伦理和中国文化》上海. 百 家出版社. 2002.01).

6. Ян Куань. Мавзолеи в Древнем Китае.- Издательство Нанкайского университета, 2010 (杨 宽: 《中国古代陵墓》. 南开大学出版社. 2010.5.1).

7. 罗开平: 《中国墓葬文化》. 海南人民出版社. 1998. Ло Кайпин. Китайская культура гробниц. Хайнань: Народное издательство Хайнаня, 1998.

8. 黄忓华: 《中国佛教史》. 吉林人民出版社. 2013. Хуан Чаньхуа. История китайского буддизма. - Чанчунь: Цзилинское народное издательство, 2013.

9. Ван Луюй. Летопись китайской скульптуры.Пекин: Издательство Сюэюань, 1989 (王鲁豫: 《中 国雕塑史册》. 北京, 学苑出版社. 1989).

10. Фэн Юлань. Краткая история китайской философии. - Пекин: Издательство Пекинского университета, 2013 (冯友兰: 《中国哲学简史》. 北 京: 北京大学出版社). 


\section{HAN-ERA FUNERARY ART OBJECTS - WORKS OF BRONZE. HAN-ERA BRONZE AESTHETICS}

Summary: Speaking of bronze here we refer to various objects made of bronze which is an alloy composed of pure copper and tin, which contains a small fraction of lead. Because bronze is an alloy, its melting point is at a lower temperature than that of pure copper, but the material itself is harder. Ji jin ${ }^{1}$ (吉金) ritual metal vessels, mentioned in ancient Chinese sources are in fact works of bronze. The invention of bronze alloys was an event of epochal historical importance. Thus, the period from the invention of bronze to ubiquitous use of iron is called the Bronze Age.

The Bronze Age in China began with the birth of the Chinese civilization. It lasted until the end of Han dynasty and had several stages of development. Works of bronze

The Bronze Age in China began ${ }^{1}$ with the birth of the Chinese civilization. It lasted until the end of Han dynasty and had several stages of development. Works of bronze first appeared in China in slave-owning society of Xia-Shang (夏商2070 BC), and reached its zenith at the peak of slave-owning system at the end of Shang (商) and the beginning of Zhou. At the end of Chunqiu (春秋475 BC) the slave-owning system began to decline, and the production of bronze items dwindled. By the end of Zhanguo (战国circa 221 BC) works of bronze mainly ritual objects - disappeared from the pages of history. During Qin and Han periods（秦汉221 BC 220 AD) ritual significance of bronze items gradually decreased. Such items got more and more use as everyday household utensils. At the same time Qin and Han is notable for great variety of bronze items' types - they were articles of daily use in the Emperor's palace, money, lanterns, mirrors. These items first appeared during Eastern Zhou period,

1. Ji jin (吉金) - old name for ritual bronze vessels used for sacrifices in Ancient China first appeared in China in slave-owning society of XiaShang (夏商2070 BC), and reached its zenith at the peak of slave-owning system at the end of Shang (商) and the beginning of Zhou. After the end of Chunqiu period (春 秋475 BC) the slave-owning system began to decline, and the production of bronze items dwindled.

In comparison to Shang and Zhou (周朝) bronze, Han objects are much smaller in size because during this period their primary purpose was to be used in common everyday life. Mystical, solemn and even somewhat barbaric bronze of Shang and Zhou was replaced by modest, practical and convenient household utensils.

Keywords: Han dynasty, works of bronze, Han-era culture, mystic utensils.

but they changed their form and appearance in the hundreds of years of Ancient China's history. Han's bronze has some distinctive features, which - it is worth noting - often serve as an inspiration for modern artists.

In comparison to Shang and Zhou (周朝) bronze, Han objects are much smaller in size because during this period their primary purpose was to be used in common everyday life. Mystical, solemn and even somewhat barbaric bronze of Shang and Zhou was replaced by modest, practical and convenient household utensils. By the Eastern Han period, with the spread of lacquerware and ironware, as well as appearance of porcelain in the middle of Eastern Han, the status of bronze items significantly decreased. Bronzeware during Han period both in its variety and style and artistic properties reflected the progress of Chinese society, retreat from mythical mindset and liberalization of public opinion - it is evident from the way the function of bronze items changed. Han period witnessed the departure from the ritual and sacred significance of bronze. 


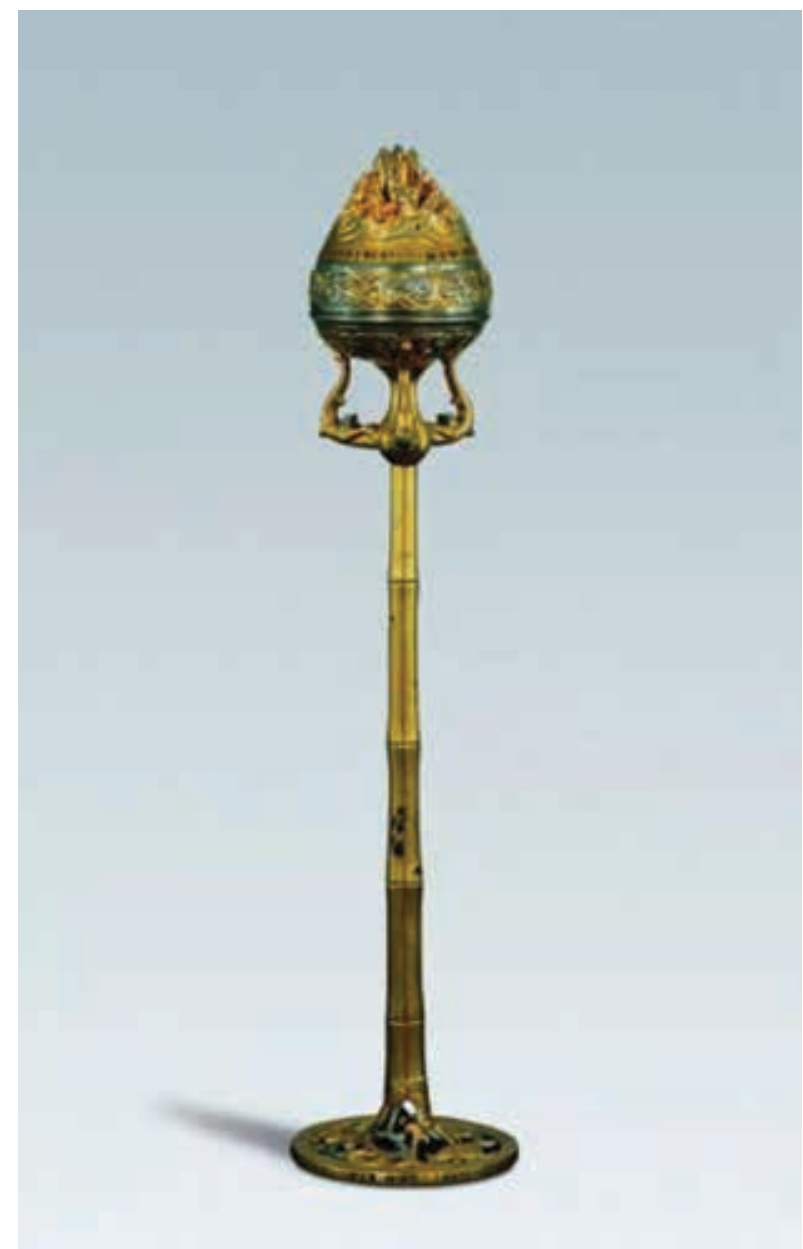

III. 1. Western Han (138 BC), gilded boshan lu incense burner with bamboo stem. $58 \mathrm{~cm}$ in height, the diameter of the bowl at the top is $9 \mathrm{~cm}$, the diameter of the base is $13.3 \mathrm{~cm}$. Found in the Maoling burial. Shaanxi History Museum

Han-era bronze household items were mainly intended for the Emperor's palace due to their high cost of production. As a rule, ornaments and decorative fixtures reflect object's functionality. An example of that is a gilded ${ }^{2}$ bronze censer on a support shaped as bamboo nodes which was found in one of the Maoling 茂陵 tombs (prov. Shanxi $\square$ Xingping 陕西口兴平) (Fig. 1). Due to its mountain-shaped lid this type of item is called boshan-lu (博山炉), i.e. Bo mountain ${ }^{3}$ shaped censer.

The height of the censer is $58 \mathrm{~cm}$, it has a hemispheric bowl, its lid is shaped like Boshan mountain and decorated with multilayered openwork picturing mountain peaks with small crevices in them. When incense was burnt in the censer, the smoke would come

2. Gilding on bronze-during the period in question bronze was gilded with charcoal, mercury and heavy metals which were baked and then transferred to the surface of the object. Therefore, the top layer on a bronze object could be made of gold or silver.

3. Bo Mountain, (博山) Boshan mountain - according to ancient Chinese sources, one of the three sacred places where the celestial beings dwell (Boshan 博山, Yingzhou 瀛洲, Penglai蓬莱)

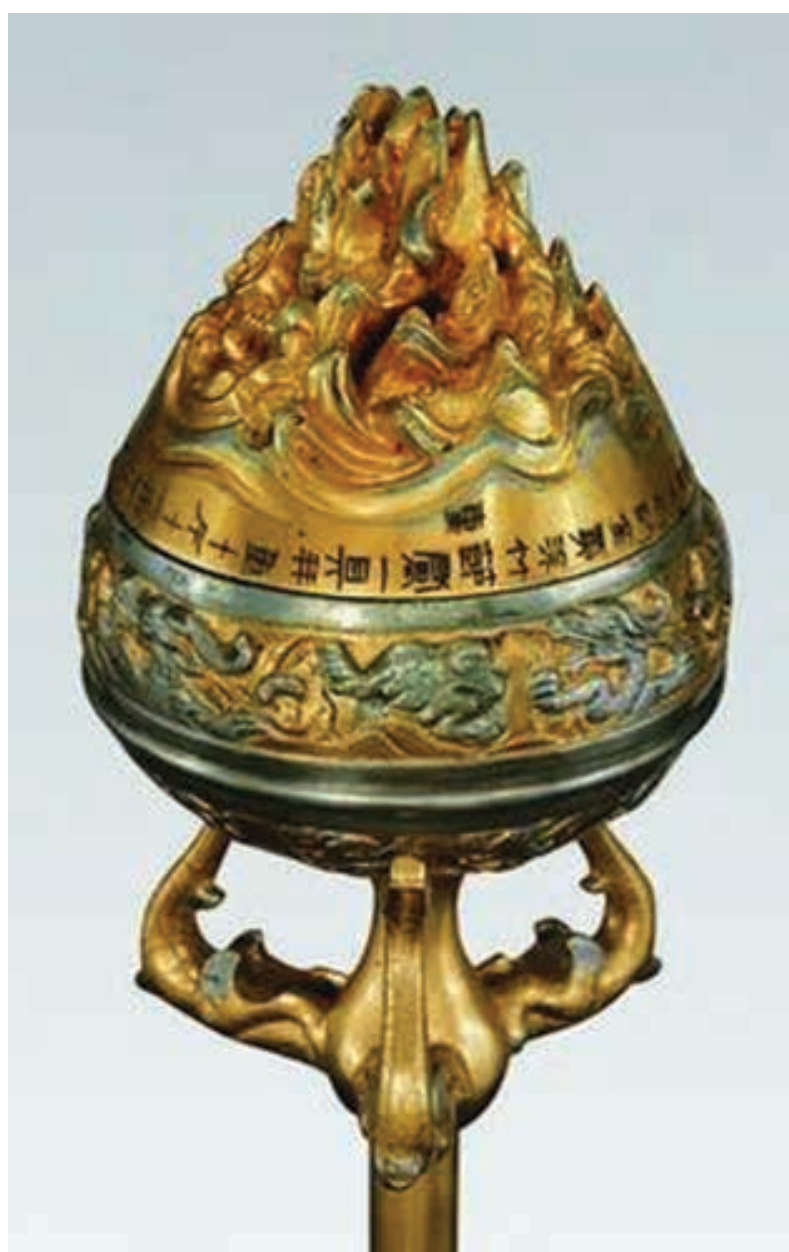

IIl. 2. Western Han (138 BC), gilded boshan lu incense burner with bamboo stem. Fragment

out of these crevices. The lower part of the censer bowl is decorated with an ornament depicting curled dragons - four golden dragons on a silver-plated background, their bodies wriggling. Ornament lines are delicate and easy, decorative fixtures are artfully crafted (Fig. 2). The bowl of the censer rests on a gilded bronze support shaped as bamboo nodes with three wriggling dragons at the top. The support is thicker at the bottom and consists of five nodes. The base is decorated with openwork, depicting two dragons who open their mouths wide to bite the bamboo.

The custom to burn incense existed in China since ancient times. Incenses were burnt not only to create a pleasant atmosphere, but also because floating aromatic incense smoke created a feeling of being close to the world of celestial beings. Such is this censer on bamboo support, with its golden and silver mountain peaks emitting thin flows of smoke, resembling some fantasy scenery. The bamboo support is there to create this dreamlike otherworldly feeling among these mountain peaks. 


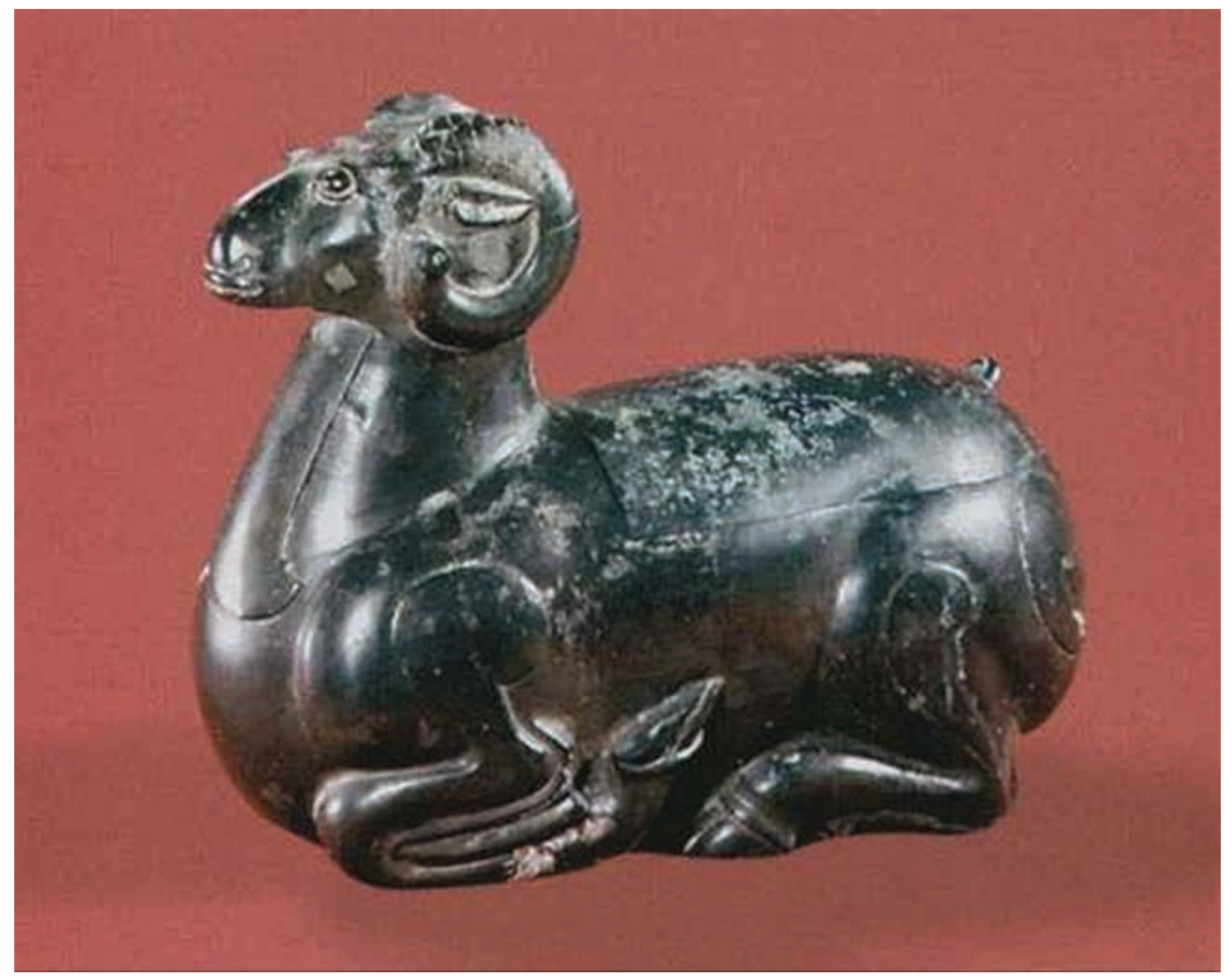

Ill. 3. Western Han. Bronze lamp in the shape of a ram. Height $18.6 \mathrm{~cm}$, Length $23 \mathrm{~cm}$. Found in 1968 in a Han burial in Mancheng. Hebei Provincial Museum

Light mist (thin streams of incense smoke) enveloping finely carved mountains enhanced this effect and made the lid of this censer truly like the mythical Boshan mountain. It is worth noting that boshan-lu censers appeared and became popular during Han period precisely due to the belief in celestial beings, which the rulers of Western Han adhered to and sought to become immortal and turn into celestial beings themselves.

Han-era left a great many of bronze items worth of a work of art status. Wide use of bronze for household items enrichened its style and artistic variety. Many various items with motifs of auspiciousness and good omen appeared, often with images of domestic cattle, phoenixes, turtles, cranes and qilin ${ }^{4}$ (麒麟). There were also rams who were believed to be auspicious animals in ancient Chinese tradition. A typical illustration of that is a lantern shaped

4. Qilin (麒麟) - the auspicious animal in Chinese Tradition. People in Ancient China believed that Qilin appearance brings luck. Sometimes the word qilin is used to describe a person of great talent and dignity. as a lying ram of the Western Han period found in the tomb of prince Zhongshan Liu Sheng（中山靖 王刘胜) (Fig. 3).

The lantern is shaped as a ram lying on its knees with its head raised high. Its head is adorned with two coiled horns, it has a short tail and oval body without any ornament. The body and back of the ram were cast separately and then joined together. The hollow space within its body contained lamp fuel. When the lantern was used, the back of the ram was lifted by the special handle and put on the ram's head (Fig. 4), creating a sort of bowl for the lantern. This piece had small channel to which a wick could be attached, so that when the light went out the remaining oil could be drained through this channel back into the lantern and the bowl was put back in its place to form the ram's back again.

The form of the lantern is well-balanced, the ram has a finished and substantial image. When lit, the lantern created an atmosphere of serenity and safety. As this example illustrates, the way of life during Han-era was reflected with finest detail in the 


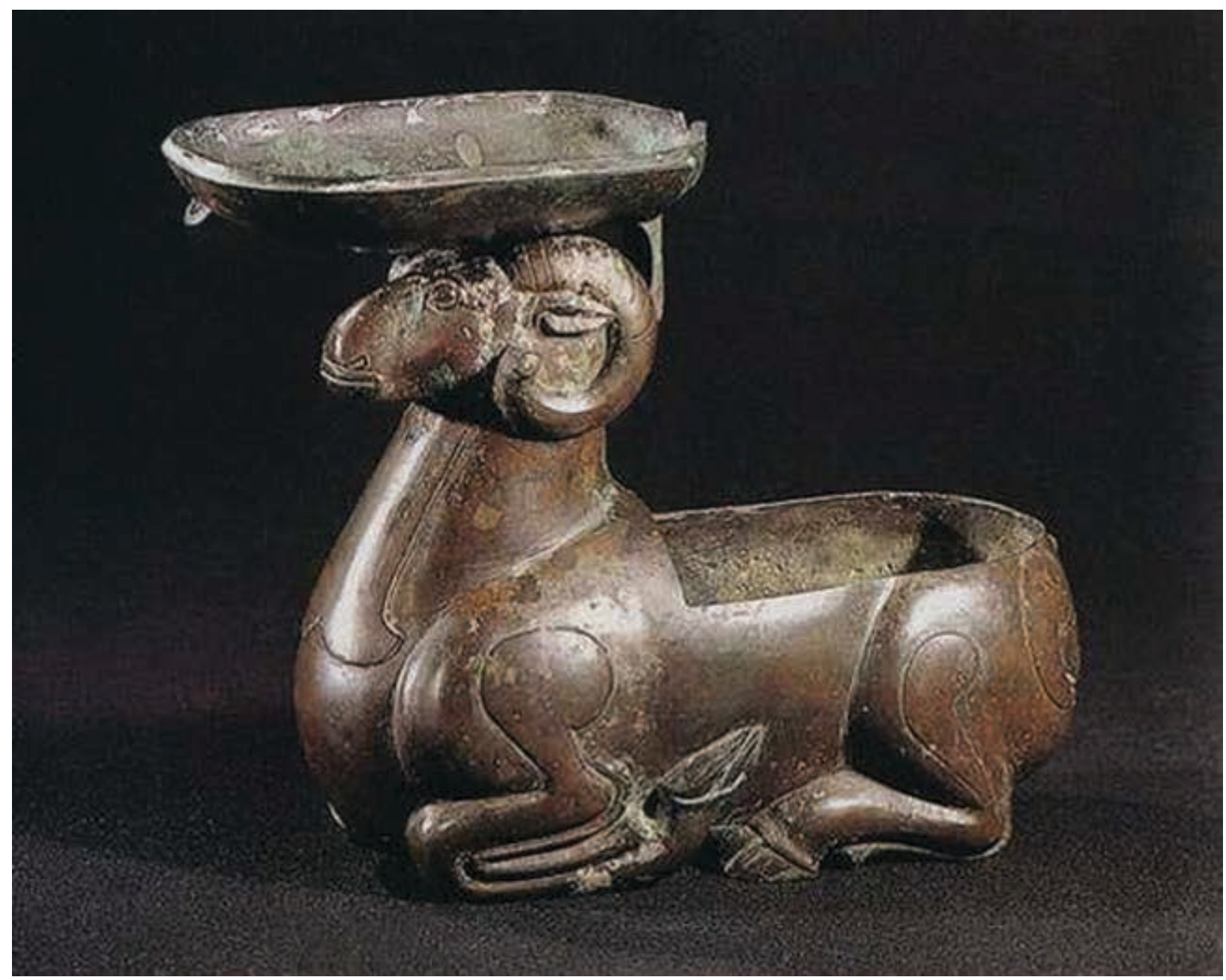

IIl. 4. Western Han. Bronze lamp in the shape of a ram

articles of daily use. The structure of this lantern with its removable bowl goes to show that during this period usability and practicality were the main requirement for any such item. The general motif in bronze item design in Han was the functionality, which was no less important than the exterior of the item.

The history of bronze casting in China dates back to antiquity. The changes in culture and aesthetic vision during Han period changed the functionality of bronze items as well - from articles 'for gods' they turned into things 'for people'. In time, having lost its sacred meaning, they went from mysticism to mundaneness - from temple sacrificial wares with its solemnity to simple and lightweight household utensils, from big and heavy to small and handy objects. Everything in Han bronze - from the form to the ornament and artistic expression features - is aimed at the fellow person and its use by one. It illustrates the change in the mindset that makes the mortal person more significant.

More than four hundred years of Han were also the last time the bronze flourished in the history of China. Bronze objects were created with great craftsmanship which required profound ingenuity and precise scientific calculations. Craftsmen from every Chinese province worked in their unique and rich style with specific inimitable artistic peculiarities. Han bronze has its own characteristic features as well. Bronze items of Han-era and their artistic style laid the background for the development of art in subsequent eras, because from this moment its focus shifted more to everyday life and the individual person. 


\section{REFERENCES}

1. Liu Junyong, Liu Tingting. 2012. "Han Material Culture in Dalian Region", Liaoning Pedagogical University Newsletter, no.1, 2012. 1. 刘俊勇, 刘婷婷, 大连地 区汉代物质文化研究，辽宁师范大学学报，2012年1期.

2. Li Xin. 2010. "Science and Art of Bronze Item Design in Ancient China", Yishu Yu She Ji, no.4. 李鈢, 古典青 铜器设计中的科学性与艺术性的统一, 艺术与设计, 2010 年4期.

3. Wang Jiashu. 1994. Applied Arts in China, Beijing: Wenhua Yishu Publishing House, p. 211. 王家树，中国工艺 美术，北京，文化艺术出版社，1994，211页.

4. Gao Feng. 1988. Applied Arts in China, Beijing: Gongyi Meishu Publishing House 高丰, 中国工艺美术研究, 北 京, 工艺美术出版社, 1998.
5. Wang Xianqian. 2012. Commentary on Zhuangzi A Collection of Wisemen Treatises, Beijing: Zhonghua Shuju，p. 65. 王先谦，庄子集解-诸子集成，北京，中华书 局, 2012, 65页.

6. Yu Weichao. 2001. General review of bronze in Qin and Han, Beijing: Wenwu Publishing House, p. 56. 俞伟超, 秦汉青铜器概论，北京，文物出版社，2001，56页.

7. Wang Zhongshu. 2001. Han-era Archaeology Digest, Beijing: Zhonghua Shuju, 2001, p. 7. 王仲殊. 汉代考古 学概说，北京，中华书局，2001.

8. Zhang Jing. 2004. Brief History of Design, Chongqing: Chongqing University Press，张晶，设计简史，重庆，重 庆大学出版社, 2004. 
Цю Мубин

Московская государственная художественно-промышленная академия им. С. Г. Строганова

e-mail: 493781521@qq.com

г. Шицзячжуан, Китай

ORCHID 000-0002-5699-7562

\section{ПРЕДМЕТЫ ПОГРЕБАЛЬНОГО КУЛЬТА В ЭПОХУ ХАНЬ - ИЗДЕЛИЯ ИЗ БРОНЗЫ. ЭСТЕТИКА БРОНЗЫ В ЭПОХУ ХАНЬ}

\begin{abstract}
Аннотация. Говоря о бронзе, мы в данном случае имеем в виду разнообразные изделия, сделанные из бронзы, то есть сплава чистой меди и олова, в котором присутствует небольшая доля свинца. Так как это сплав, температура плавления у бронзы ниже, чем у чистой меди, при этом материал тверже. Ритуальные металлические сосуды «цзи цзинь» ${ }^{1}$ (吉金), упоминаемые в древнекитайских источниках, - это именно изделия из бронзы. Изобретение сплава бронзы было событием эпохальной, исторической важности. Поэтому в археологии период от изобретения бронзы до повсеместного распространения железа называется «бронзовым веком».

В Китае бронзовый век начался с возникновением китайской цивилизации и длился до конца эпохи Хань, развиваясь поэтапно. Бронзовые изделия впервые появились в Китае в рабовладельческом обще-
\end{abstract}

В Китае бронзовый век ${ }^{1}$ начался с возникновением китайской цивилизации и длился до конца эпохи Хань, развиваясь поэтапно. Бронзовые изделия впервые появились в Китае в рабовладельческом обществе Ся-Шан (夏商2070 г. до н.э.), достигая расцвета одновременно с пиком развития рабовладельческого строя в конце Шан (商) - начале Чжоу. После периода Чуньцю (春秋 475 г. до н.э.) начался упадок рабовладельческого строя, вместе с тем в сошло на нет и производство бронзовых изделий. К концу Чжаньго (战国ок. 221 г. до н.э.) бронзовые изделия, преимущественно ритуальный инвентарь, покинули страницы истории. В периоды Цинь и Хань

1. «Цзи цзинь» (吉金) - старое название ритуальной бронзовой посуды, которая в Древнем Китае использовалась для жертвоприношений. стве Ся-Шан (夏商2070 г. до н.э.), достигая расцвета одновременно с пиком развития рабовладельческого строя в конце Шан (商) - начале Чжоу. После периода Чуньцю (春秋475 г. до н.э.) начался упадок рабовладельческого строя, вместе с тем сошло на нет и производство бронзовых изделий.

По сравнению с бронзой Шан и Чжоу (周朝), изделия в Хань гораздо меньше по размеру, ведь в этот период они предназначались в первую очередь для того, чтобы их использовали в повседневной жизни. Мистической, торжественной и даже в чем-то варварской бронзе Шан и Чжоу на смену пришла более скромная, практичная и удобная для использования повседневная утварь.

Ключевые слова: династия Хань, изделия из бронзы, культуры эпохи Хань, таинственная утварь.

(秦汉221 г. до н.э. - 220 г.н.э.) ритуальное значение бронзовой утвари постепенно уменьшалось, изделия из бронзы всё больше и больше использовались для обыденных, повседневных нужд. В то же время период Цинь и Хань отличался большим разнообразием видов бронзовых изделий - это были предметы обихода в императорском дворце, деньги, фонари, зеркала. Это были изделия, впервые появившиеся в период Восточной Чжоу, но менявшие форму и вид на протяжении столетий истории Древнего Китая. У ханьской бронзы есть свои отличительные черты, которые, стоит отметить, часто служат вдохновением для современных художников.

По сравнению с бронзой Шан и Чжоу (周朝)， изделия в Хань гораздо меньше по размеру, ведь в этот период они предназначались в первую 
очередь для того, чтобы их использовали в повседневной жизни. Мистической, торжественной и даже в чем-то варварской бронзе Шан и Чжоу на смену пришла более скромная, практичная и удобная для использования повседневная утварь. К Восточной Хань, с распространением лаковых и железных изделий, появлением фарфора в середине Восточной Хань, статус изделий из бронзы значительно понизился. Бронзовая утварь в период династии Хань, и по своему разнообразию, и по стилю и художественным особенностям, отразила прогресс китайского общества, отход от мифического мышления и либерализацию общественного сознания - это видно по тому, как сменялась функция бронзовых изделий. В Хань происходит отход от ритуального, сакрального значения бронзы.

Бронзовые изделия для повседневного пользования в эпоху Хань из-за сравнительно высокой себестоимости при изготовлении в основном предназначались для императорского дворца. Орнаменты и декоративные элементы на этих изделиях, как правило, отражают их функциональное предназначение. В пример стоит привести найденную в одном из захоронений в Маолин 茂陵 (пров. Шэньси, Синпин陕西, 兴平) позолоченную ${ }^{2}$ бронзовую курильницу на подножке в форме коленцев бамбука (ил. 1). Благодаря своей крышке в форме горы такой тип изделия называется «бошань-лу» (博山炉), т.е. «курильница в виде горы Бо» ${ }^{3}$.

Высота курильницы 58 см, чаша полусферическая, крышка сделана в виде горы Бошань и украшена многослойной ажурной резьбой, изображающей пики гор, между которыми есть небольшие зазоры. Когда в курильнице жгли благовония, из этих зазоров выходил дым. Нижняя часть чаши курильницы украшена орнаментом с изображением свернувшихся драконов - это четыре золотых дракона на посеребрённом фоне, тела драконов извиваются. Линии орнамента изящные и свободные, декоративные элементы сделаны с большим мастерством (ил. 2). Чаша курильницы стоит на позолоченной бронзовой

2. Позолота на бронзе - в рассматриваемый период бронзу золотили при помощи древесного угля, ртути и тяжёлых металлов, которые обжигались, а затем наносились на поверхность изделия. Верхний слой на бронзовом изделии таким образом мог быть из золота или серебра.

3. Гора Бо, (博山) гора Бошань - согласно древнекитайским источникам, одно из трёх священных мест на море, где проживают небожители (Бошань 博山, Инчжоу 瀛洲, Пэнлай 蓬莱) ножке в форме коленцев бамбука с тремя извивающимися драконами сверху. Ножка утолщается к низу и состоит из пяти коленцев. Основание украшено резьбой, изображающей двух драконов, широко раскрывающих пасть и вцепившихся зубами в бамбук.

Обычай жечь благовония существовал в Китае с древности. Это делалось не только для создания приятной атмосферы, но ещё и потому, что ароматный и струящийся дым от благовоний создавал ощущение близости к миру небожителей. Так и эта курильница на бамбуковой ножке, с её золотыми и серебряными горными вершинами, из которых струился дым, напоминает некий сказочный пейзаж. Бамбуковая ножка нужна для того, чтобы создать это ощущение сказочности, иномирности горных вершин. Лёгкий туман, окутывающий тонко вырезанные горы (то есть струйки дыма от благовоний), усиливал этот эффект, и действительно уподоблял крышку курильницы мифической горе Бошань. Следует сказать, что курильницы бошань-лу появились и стали популярными в Хань именно благодаря вере в небожителей, которой придерживались правители Западной Хань, и сами искавшие способ достичь бессмертия и стать небожителями.

От эпохи Хань осталось великое множество бронзовых изделий, заслуживающих статуса произведений искусства. Широкое использование бронзы для изготовления повседневной утвари обогатило её стиль и художественное разнообразие. Появилось немало разнообразных изделий с мотивом благовещения и доброго предзнаменования, и часто на них встречаются образы домашнего скота, фениксов, черепах и журавлей, цилиня ${ }^{4}$ (鹿麟). Можно также увидеть и баранов, также считавшихся благовещими животными в древнекитайской традиции. Характерный пример - светильник в виде лежащего барана периода Западной Хань, найденный в могиле принца Чжуншаня Лю Шэна (中山靖王刘胜) (ил. 3).

Светильник изготовлен в форме лежащего на коленях и высоко вскинувшего голову барана. На голове барана два витых рога, хвост короткий, тело овальное, лишённое орнамента. Тело и спина барана были отлиты отдельно и затем соединены вместе. В полое пространство внутри

4. Цилинь (麒麟) - благовещий зверь в китайской традиции. В Древнем Китае верили, что появление цилиня предвещает удачу. Иногда слово «цилинь» используется, когда говорят о выдающемся, талантливом и благородном человеке. 
тела барана помещалось топливо для горения. Когда лампу использовали, спинка барана приподнималась за специальную ручку, снималась и клалась барану на голову (ил. 4), превращаясь в своеобразную чашу для светильника. Эта спинка была оснащена небольшим каналом, к которому можно приставить фитиль, а когда лампа потухала, оставшееся масло сливалось по этому каналу обратно внутрь светильника, чаша переворачивалась и возвращалась на своё место, вновь становясь спиной барана.

Форма светильника гармоничная, образ барана законченный и основательный, когда светильник был зажжён, создавалась атмосфера спокойствия и безопасности. Как видно в случае с данным бронзовым изделием, образ жизни в эпоху Хань до мельчайших крупиц отражался в предметах обихода. Строение светильника, с его съёмной чашей показывает, что в этот период удобство в использовании и практичность были основным требованием к изделию. Главным мотивом в дизайне бронзовых изделий в Хань стала функциональность, которой придавалось не меньшее значение, чем внешнему облику предмета.

История литья бронзы в Китае уходит корнями в глубокую древность. Изменения в культуре и эстетических воззрениях в период Хань изменили и функциональное предназначение изделий из бронзы - из изделий «для богов» они превратились в изделия «для людей». Утратив со временем своё сакральное значение, они прошли путь от мистицизма до обыденности - от храмовой жертвенной посуды с её строгой торжественностью до простой и лёгкой хозяйственной утвари, от больших и тяжёлых изделий до маленьких и практичных. Всё в ханьской бронзе - от формы изделия до орнаментов и художественных средств выразительности - нацелено на человека и использование изделия человеком. Это показывает и смену мировоззрения, при котором человеку придаётся больше значения.

Четыреста с лишним лет истории Хань были также и временем последнего расцвета бронзы в истории Китая. Изделия из бронзы создавались с великим мастерством, требовавшим искусности и точных научных расчётов. Мастера каждой из китайских династий создавали изделия в своём уникальном, богатом стиле, обладающим своими неповторимыми художественными особенностями. Есть свои характерные особенности и у ханьской бронзы. Бронзовые изделия в эпоху Хань и их художественный стиль заложили основу для развития искусства в последующие эпохи, ведь с этого момента оно начало больше фокусироваться на жизни и человеке.

\section{БИБЛИОГРАФИЯ}

1. Лю Цзюньюн, Лю Тинтин. Материальная культура Хань в районе Далянь // Вестник Ляонинского педагогического университета.— № 1, 2012. 刘俊勇, 刘婷婷，大连地区汉代物质文化研究，辽宁师范大学学 报, 2012年1期.

2. Ли Синь. Наука и искусство в дизайне бронзовых изделий Древнего Китая // «Ишу юй шэ цзи».№ 4. - 2010. 李金金, 古典青铜器设计中的科学性与艺 术性的统一，艺术与设计，2010年4期.

3. Ван Цзяшу. Прикладное искусство Китая.-Пекин: Изд. «Вэньхуа ишу», 1994.- C. 211. 王家树, 中国工 艺美术，北京，文化艺术出版社，1994，211页.

4. Гао Фэн. Прикладное искусство Китая.-Пекин: Изд. «Гунъи мэйшу», 1998. 高丰, 中国工艺美术研究, 北京， 工艺美术出版社, 1998.
5. Ван Сяньцянь. Комментарии к Чжуан-цзы - сборник трактатов мудрецов. - Пекин: Чжунхуа шуцзю, 2012.－ C. 65. 王先谦，庄子集解-诸子集成，北京，中华 书局, 2012，65页.

6. Юй Вэйчао. Общий обзор бронзы в Цинь и Хань.Пекин: Изд. «Вэньу», 2001. - 56 с. 俞伟超, 秦汉青铜 器概论，北京，文物出版社，2001，56页.

7. Ван Чжуншу. Очерк археологии эпохи Хань.- Пекин: Чжунхуа шуцзю, 2001. С. 7. 王仲殊. 汉代考古学 概说，北京，中华书局，2001.

8. Чжан Цзин. Краткая история дизайна.- Чунцин: Изд. Чунцинского университета, 2004. 张晶, 设计简 史, 重庆, 重庆大学出版社, 2004. 
Associate of the International Center for Korean Studies, the Institute of Asian and African Studies, Lomonosov Moscow State University,

Aspirant of the Art History and Humanities Department of the Stroganov Moscow State Academy of Arts and Industry e-mail: dolihotella@hotmail.com Moscow, Russia

\section{THE HWAJOHWA GENRE (BIRD-AND-FLOWER PAINTING) IN KOREAN TRADITIONAL PAINTING OF THE EARLY AND MIDDLE CHOSŎN PERIODS (LATE $14^{\text {TH }}-$ LATE $17^{\text {TH }}$ CENTURIES)}

Summary: The article is devoted to the hwajohwa artistic genre (bird-and-flower painting) of the early and middle Chosŏn periods (late $14^{\text {th }}-$ late $17^{\text {th }}$ centuries). The study identifies the historical and cultural context, the stylistic evolution of the bird-and-flower painting and the main terms for its designation. It presents individual artistic trends, examines the techniques used in Korean traditional painting. Moreover, the author outlines the leading artists who worked in this genre during the indicated period.

In the early Chosŏn period (1392 - c. 1550), the hwajohwa genre gained particular relevance in traditional Korean painting, and a high artistic level was achieved in it. Vivid painting in the bird-and-flower genre, made in the academic style of court painting, became the most common and indicative of this historical period. In the process of the formation and strengthening of the positions of the new Yi dynasty, the ruling circles commissioned social paintings. Therefore, the works are characterised by an optimistic mood; the compositions are full of idyll and harmony with the world around them. Artist Yi Am, who laid the foundations for the development of the hwajohwa genre in Korea, was the most prominent representative of this movement. At the same time, scholar painters began

In the studies of Korea in Russia, there are a number of scientific works in which the subjects of birds and plants became the objects of research. For example, cosmogonic myths have been well studied; the motif of birth from an egg of anthropomorphic ancestors, the founders of the ancient Korean states, is often found there [4, pp. 436, 441, 449]; paintings of birds and floral ornaments on the famous frescoes in the tombs of Koguryŏ are carefully described [2]; there are linguistic studies concerning to create small landscapes with birds, made only with water and ink. Confucian scholar Kim Jŏng is rightfully considered the founder of this scenic movement.

The Middle Joseon period (c. 1550-1700) was characterised by the flourishing of the hwajohwa genre in the technique of monochrome ink painting. Many intellectual artists from the upper strata of Korean society emerged, for whom the bird-and-flower genre became a means of expressing deep personal relationships with nature and the world around them. Korea of the second half of the $16^{\text {th }}-17^{\text {th }}$ centuries suffered from numerous foreign invasions; thus, lonely and weary birds, sleeping or resting on the branches of trees, became the main and most popular motif in the hwajohwa genre. Such painting was a direct reflection of the feelings of the educated stratum of Korean society about the fate of their homeland. Paintings by scholar painter Cho Sok and court painter Yi Jin were the most popular works of the bird-and-flower genre of this period.

Keywords: Korean traditional painting of the Chosŏn period, the genre of hwajohwa (the bird-and-flower painting), Yu Jami, Yi Am, Kim Jŏng, Sin Saimdang, Yi Yŏngyun, Yi Jing, Cho Sok, Kim Sik, Yi Ham, Cho Jiun.

the animal and plant world [5]. However, in Russian art history, there are no particular works devoted to the genre of hwajohwa (the bird-and-flower painting) in Korean traditional painting, except for a brief description of artist Chang Sŭngŏp's scroll Wild Geese by L. Kireeva [3].

In the presented article, the author bases her study on the research of South Korean scientists, first of all, Professor Hong Sonn'yo [6] and his proposed periodisation and terminology. The leading 
artists who became famous in the indicated painting movement and technical and stylistic features, typical for the bird-and-flower genre of the periods under consideration, are in the centre of attention.

The history of depicting birds and flowers in Korea has deep roots. Since ancient times, birds, as divine living beings, have been objects of worship and inspiration in the Korean cultural and artistic tradition, which took its origins and developed in tandem with the Chinese tradition. They adorned various artefacts and were used as benevolent symbols attracting longevity, rich and abundant life full of health, honour, luck and love, and also embodied the absolute principles of order and harmony of Nature. Images of flowers and birds brought beauty and grandeur to royal palaces and the homes of the nobility. They became very popular as paintings depicting scenes of paradise.

During the Koryŏ dynasty (918-1392), when Korean art acquired complex and sophisticated forms, a new painting tradition began to form, and the depiction of flowers and birds became an independent genre. Unfortunately, not a single work in the birdand-flower genre of the Koryŏ period has reached us. We encounter flowers and birds only as elements included in the Buddhist religious painting of this period.

Hwajohwa painting flourished during the Chosŏn era (Yi Dynasty, 1392-1910) - a period of five hundred years in Korean history. The early Chosŏn period is conventionally dated 1392-1550, the middle 1550-1700.

In Korea, hwajohwa (화조(화) 花鳥(畫) literally "the bird and flower painting") began to be used as a term for an art genre, borrowed from China, from the $15^{\text {th }}$ century, at the beginning of the Chosŏn era. The earliest Korean text that contains this term is the Records of Paintings (Hwagi, 화기 畫記), written by Sin Sukchu (신숙주 申叔舟, 1417-1475) in 1445. However, there are several other terms referring to this genre synonymous to hwajo: chosuch'omok (조수초목 鳥獸 草木 birds, animals, grass and trees), hwamokkŭmjo (화목금조 花木禽鳥 flowers, trees and birds) and hwajomoksǒk (화조목석 花鳥木石 flowers, birds, trees and animals) $[6$, p. 45]. The art albums of the Chinese Ming Dynasty (1368-1644) used the term lingmao (领毛 "fur and feathers", Korean yŏngmo 영모) to refer to animal and bird images; it became widely used in the Middle Chosŏn period, as did the terms hwahweyŏngmo (화훼영모 花卉领毛 flowers, birds and animals) and hwach'oyŏngmo (화초영모 花草 领毛 flowers, grass, birds and animals).

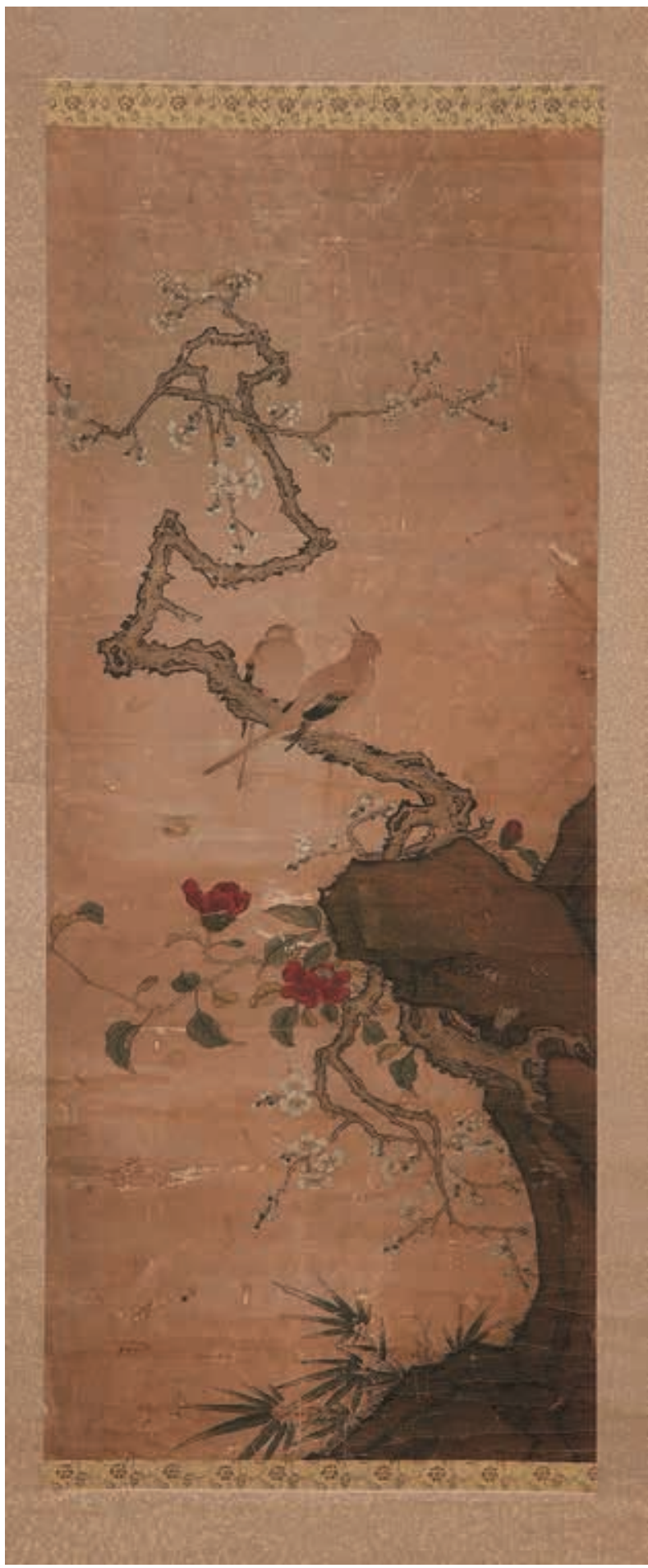

IIl. 1. Presumably Sin Jam, Flowers and Birds, paper, ink, water paints, chkhesek technique (채색 彩色 painting the depicted image after drawing its outline), $116 \times 45.7 \mathrm{~cm}, 16^{\text {th }}$ century National Museum of Korea, Seoul

The article uses the terms hwajohwa to denote the bird-and-flower genre and hwajodo (화조도 花鳥圖), indicating paintings made in this genre. It is essential to point out that the emphasis of this study is made precisely on paintings with birds and plants and not on animals, which are also included in the genre. 


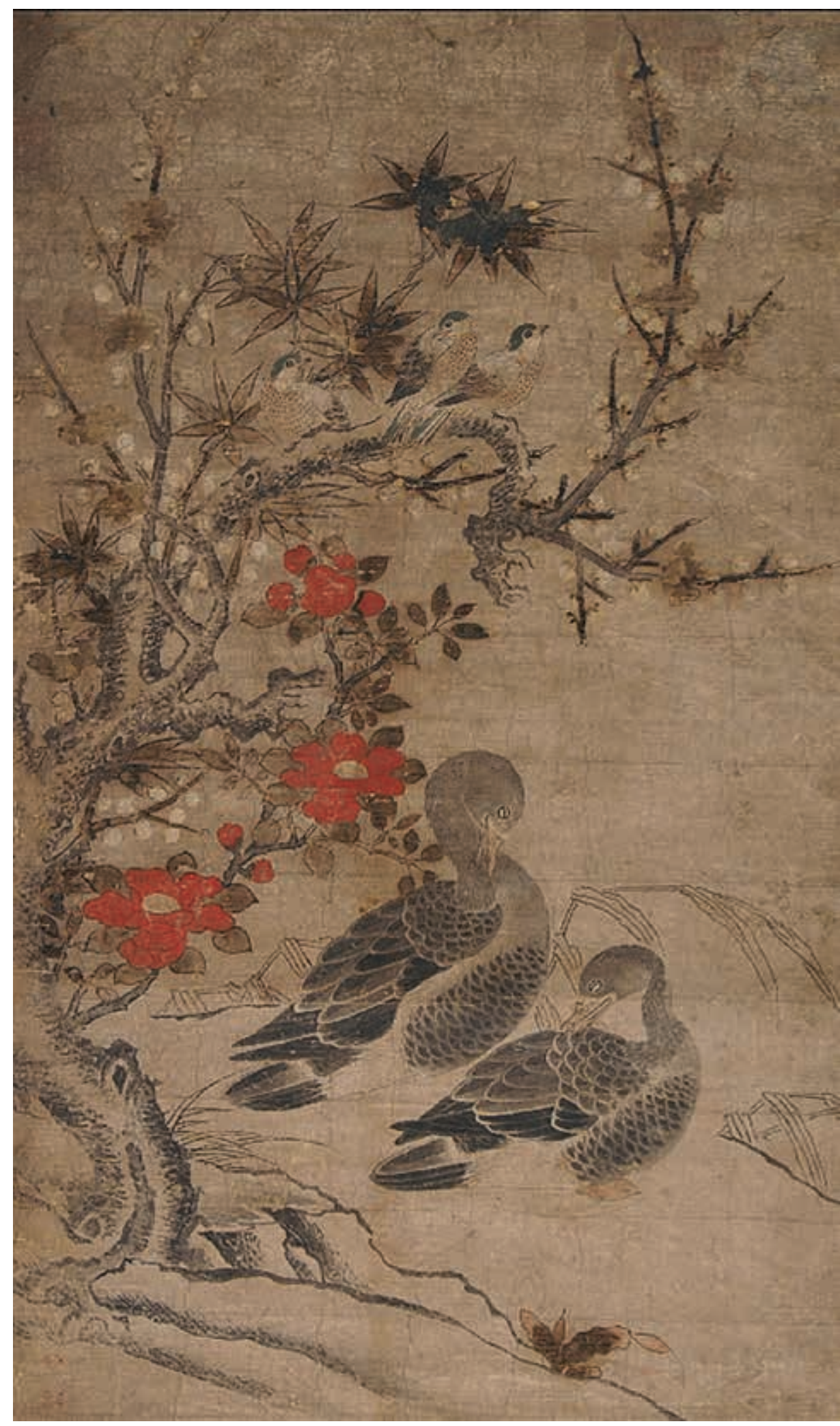

IIl. 2. Yi Am, A Pair of Wild Geese, paper, ink, water paints, chkhesek technique, $84.7 \times 50 \mathrm{~cm}$, mid-16 ${ }^{\text {th }}$ century, Korean Art Gallery, Pyongyang

\section{Hwajohwa in the Early Chosŏn Period}

(1392 - c. 1550)

In the early Chosŏn period (1392 - c. 1550), the hwajohwa genre gained particular relevance in traditional Korean painting, and a high artistic level was achieved in it. Realistic painting in the stylistic movements of kurǔkchonch'aep'ung (구륵전채풍 鉤勒﨏彩風 the contour of the depicted objects is done with ink and filled with colour) and molgolch'aesaekp'ung (몰골채색풍 沒骨彩色風 "boneless" painting with ink and mineral paints is without contour) was officially spread and applied in practice among the hwawŏn court painters (화원 畫員) of the Tohwasŏ Royal Academy of Painting (도화서 圖畫 暑), who satisfied the growing artistic demands of the royal family.

In accordance with the Code of Rites ( $Y e$ jŏn 예전 禮典) of the Complete Code of Law (Kyŏngguktaejŏn 경국대 전 經國大典 was finally formed by 1485), there was ch'wijae - a system of selection and examination of court artists (취재 取材) [6, p. 49]. In the examinations, the images of flowers and birds, as well as the images of human figures, were given the third place in importance (the first was occupied by bamboo, the second by landscape).

For the royal family, court artists often created images of a falcon in a precise, realistic manner, called haech'ŏngdo (해청도 海靑圖), painted special paintings in the saehwa genre (새화 歲畫) for the New Year, which Korean king gave to relatives and high-ranking officials on the occasion of a holiday. For example, 

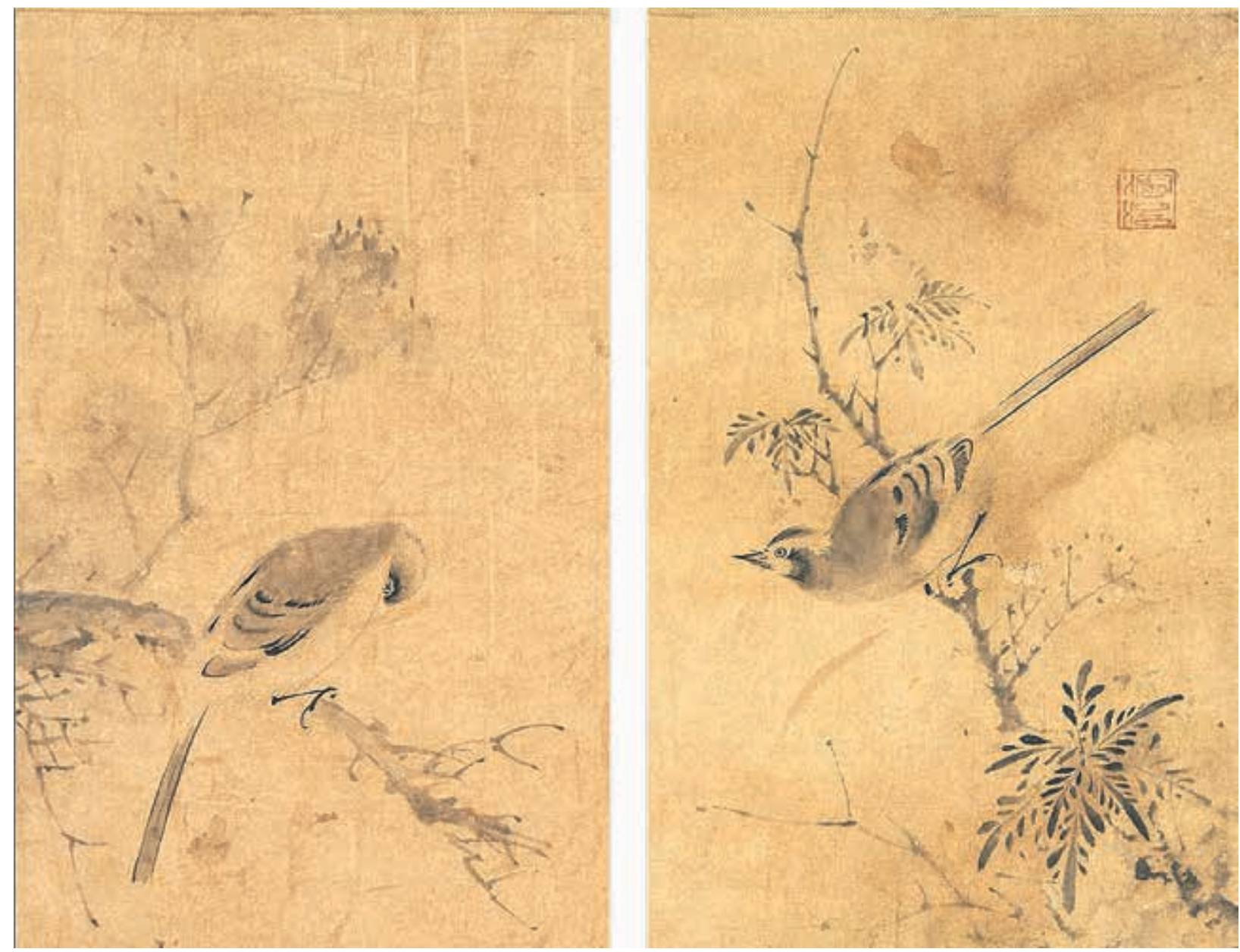

Ill. 3. Kim Jŏng, Flowers and Birds, paper?, ink, sumuk technique (수묵 水墨 monochrome ink painting), total size: $19.5 \times 23.5 \mathrm{~cm}$ early $16^{\text {th }}$ century, Korean Art Gallery, Pyongyang

ch'uŭngpakt'odo (추응박토도 秋鷹搏鬼圖) - an image of a falcon hunting a rabbit in autumn.

At the same time, the upper stratum of the Korean medieval society, sadaebu (사대부 士大夫), who along with the ruling family were the main customers and patrons of the arts, perceived hwajohwa as a symbol of harmony with nature, kanghohanjŏng (강호한정 江湖閒靜 silence/tranquillity in nature), and superiority over everything worldly [6, p. 49].

The following birds were most often depicted in paintings in the hwajohwa genre: ducks, egrets, cranes, falcons, wild geese, swallows, gulls, sparrows, magpies, pigeons, orioles, peacocks, roosters and hens. They were painted in different positions against the background of flowers, grasses, bamboo, trees or stones.

Korean art critics conventionally divide all the hwajodo paintings of the Chosŏn period into two main painting styles. The first is ch'aemukp'ung (채묵풍 彩墨風) - ink and water-based painting. In the paintings in the ch'aemukp'ung style, birds were painted with small brush strokes, neat lines with colour and ink against the backdrop of a taegyŏng landscape (대경 大景 literally "large landscape") with trees at the top of the canvas and water or stones at the bottom. The ch'aemukp'ung style in the early Chosŏn period developed from Koryŏ painting. It was also influenced by the realistic decorative traditions inherent in the academic painting schools of the early Ming dynasty.

Very few Korean paintings made in Chinese academic painting techniques have survived. These are Pines and Cranes in the Valley (지곡송학도 芝 谷松鶴圖) by Yu Jami (유자미 柳自挶, creative pseudonym - Sŏsan 서산 西山, ? -1462) from the Kansong Art Museum [10, pp. 19-21], four paintings Flowers and Birds (Fig. 1) by Sin Jam (신잠 申潛, pseudonym - Yŏngch'ŏnja 영천자 靈川子, 1491-1554) and one work by An Gwisaeng (안귀생 安貴生, the end of the $15^{\text {th }}$ century,?-?) from the National Museum of Korea.

Also, a series of paintings with flowers, birds, a cat, a dog and puppies by famous artist Yi Am (이암 李嚴, pseudonym - Chŏngjung 정중 靜仲, 1499-1566?) 


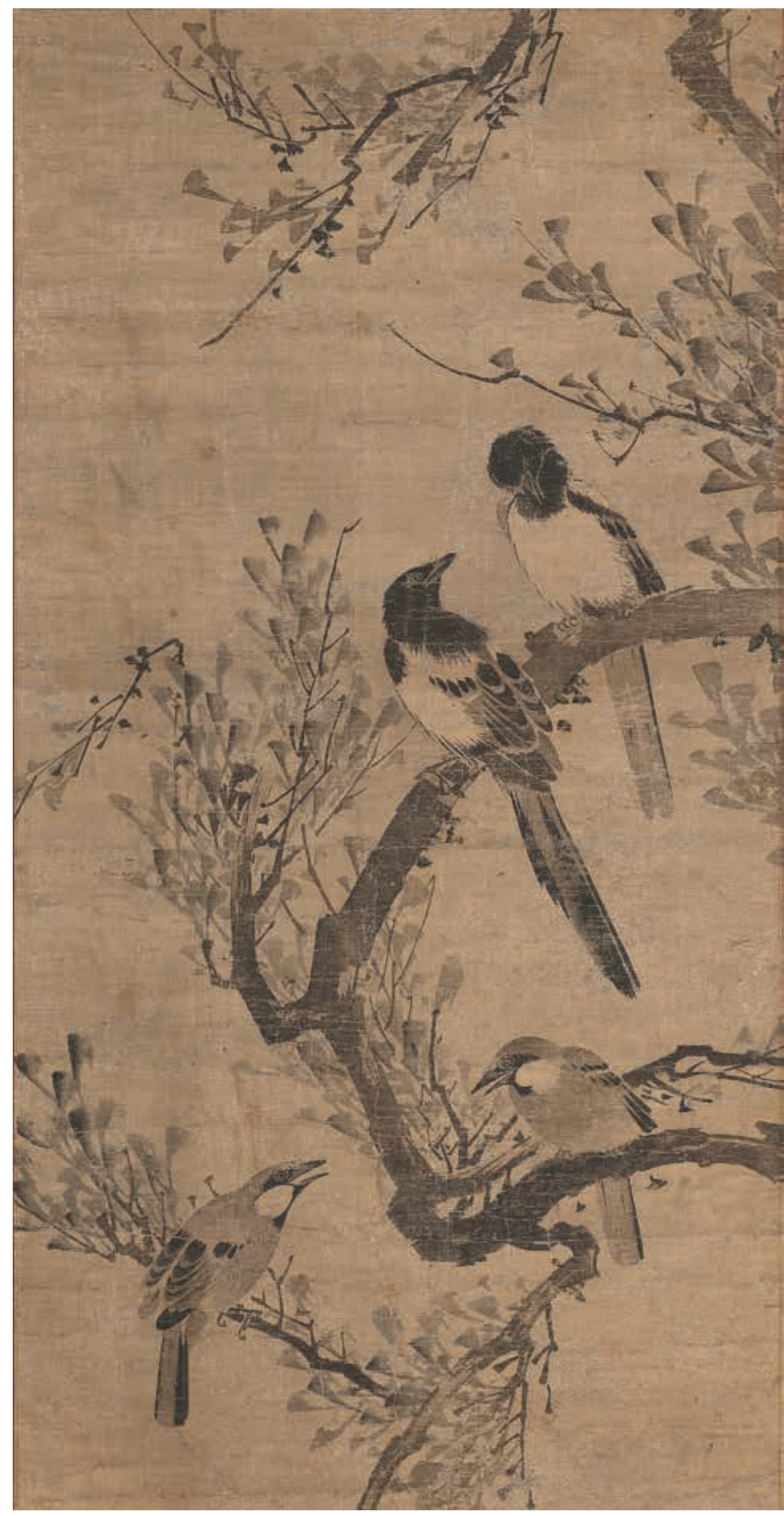

Ill. 4. Cho Sok, Magpies Living on an Old Tree, silk, ink, sumuk technique, $112.4 \times 57.3 \mathrm{~cm}$, $17^{\text {th }}$ century, National Museum of Korea, Seoul has been preserved. One painting from this series is kept at the $\mathrm{Na}$ tional Museum of Korea, one at the Jinju National Museum, one at the Leeum Museum, two at the Korean Art Gallery in Pyongyang, and another at The Japan Folk Crafts Museum in Tokyo. Also, Yi Am's scroll A Pair of Wild Geese (한쌍의 기러기) is preserved in the Pyongyang Art Gallery (Fig. 2) [8, pp. 77-82].

The paintings mentioned above depict a variety of birds or animals, trees, plants, flowers, stones, hills and mountains at different times of the year in the style of the Zhe painting school (浙派 zhe pai), or the Zhejiang school of the Ming dynasty, which is characterised by two-dimensionality, decorative flatness, asymmetrical composition, enhanced contrast of light and dark, a combination of realistic and decorative elements, often reminiscent of abstract patterns made with ink and water paints.

Lü Ji（呂紀 1477?1505?), a recognised Chinese master of court academic painting, who worked in the bird-andflower genre, made the greatest influence on Korean hwajohwa painting of the early Chosŏn period. This artist was imitated by An Gwisae$\mathrm{ng}$, his techniques were 
used by Sin Jam; however, they are most vividly reflected in Yi Am's paintings [6, p. 50]. Interestingly, Yi Am came from the royal family. It is believed that the bright, lyrical, ideal pictorial world he created laid the foundations for the development of hwajohwa in Chosŏn.

The second notable stylistic trend is sumukp'ung (수묵풍 水墨風), water and ink painting, monochrome ink painting. A sumukp'ung painting is a microlandscape, sogyŏng (소경 小景 literally "small landscape"), which depicts one or two birds of the same species. Sumukp'ung, with its gravitation towards improvisation and violation of academic canons, developed as a new independent style from mukhŭi (묵희 墨戯) - "an ink game", associated with the painting of amateur munin artists (문인 文人 Confucian scholars, intellectuals) and Chan Buddhist artists both in China and in Korea.

Small sogyŏng ink works were usually of two types. In the paintings of the first type, one or two birds sitting on a long, sometimes flowering chŏlji branch (절지 折枝 a branch without an image of the tree trunk) were painted [6, p. 50]. Most often, wagtails, great tits, snipes, magpies were depicted on plum or bamboo branches. They were painted with sharp, dynamic strokes of chop'il (조필 粗筆 rough/hard brush) and pangp'il (방필 放筆 free hand technique). Paintings are inherent in lapidarity, saǔich'e - the socalled "painting of an idea" (사의체 寫意體), which seeks not so much to accurately convey the image as to express its essence, spirit in bold free strokes of the brush. The second type is a landscape with stones, rocks, aquatic plants located at the edge of a reservoir, in which herons, waterfowl or birds living near the water are often depicted. Paintings of this type are similar to small landscapes of the Southern Song dynasty (1127-1279) and landscapes in the style of the Zhe school of the Ming dynasty. They are characterised by the pyŏngak composition (변각 邊角) - the concentration of all the main objects of the image in one corner [6, p. 51].

Few works of the sumukp'ung trend of the early Chosŏn period have been preserved. Intellectual artist Kim Jŏng (김정 金淨, pseudonym - Ch'ungam, Kobong 충암 冲菴, 고봉 孤峯, 1486-1521) worked in this style. His paintings White-headed Birds on Zanthoxylum (산초백두 山椒白頭) and Bird on a Thin Branch (영모절지도 领毛折枝圖) are in private collections, and two works Flowers and Birds (화조도 花鳥圖) are in the Korean Art Gallery in Pyongyang (Fig. 3).
Also, paintings by the only female artist of the Chosŏn period, Sin Saimdang (신사임당 申師任 堂, 1504-1551), are preserved: White Herons (백로도 ⿱㇒日 鷺圖) from the Seoul National University Museum, White Wagtail (알락할미새) from the Ehwa Womans University Museum and Pair of Mandarin Ducks (원앙도 鴐穒圖) from a private collection. These are excellent examples of small landscapes made at leisure for "self-joy" [1, pp. 70-71]. Such works are designed to instil a sense of tranquillity and harmony with nature; they do not depict birds and the living world around them with anatomical precision.

The National Museum of Korea houses a hwajodo, Crane on a Pine (송학도 松鶴圖), by the artist of the early Chosŏn period, Yi Jongjun (이종준 李宗準, pseudonym - Yongjaegong 용재공 慵齋公, ? -1499). This is a kind of intermediate option between the two considered trends. A crane standing on a thick pine branch is painted in ink but with a slight colour accent added to the work.

To sum up, it should be noted that a new dynasty was formed in the early Chosŏn period, and its ruling authority was strengthened. The bird-andflower genre and all Korean painting of this historical period are characterised by an optimistic mood; artists created compositions full of idylls, painted a harmonious and beautiful world under heaven, fulfilling the social order of the ruling circles, or satisfying their creative ambitions.

\section{Hwajohwa in the Middle Chosŏn Period (c. 1550-1700)}

In the middle Chosŏn period, hwajohwa painting reached its peak. In the flight and singing of birds, scholars saw the personification of paradise, pure pleasure, the quintessence of the fundamental truth of the cosmological movement of all things [6, p. 52]. The bird-and-flower genre became a means of expressing deep personal relationships between man and nature. Many scholar painters from the upper strata of Korean society, who belonged to the royal court or were officials, appeared during this period.

Artists such as Yun Ŏm (윤엄 尹㒤, pseudonym Songam 송암 松嚴, 1536-1581) and Li Youngyun (이영윤 李英)胤, pseudonym - Chungnimsu 죽림수 竹林守, 1561-1611) continued to create typical two-dimensional large academic-style hwajodos similar to those painted in the early Chosŏn period.

However, small drawings of birds, made only with water and ink, were the most numerous, widespread and illustrative hwajodos of the middle Chosŏn period. 


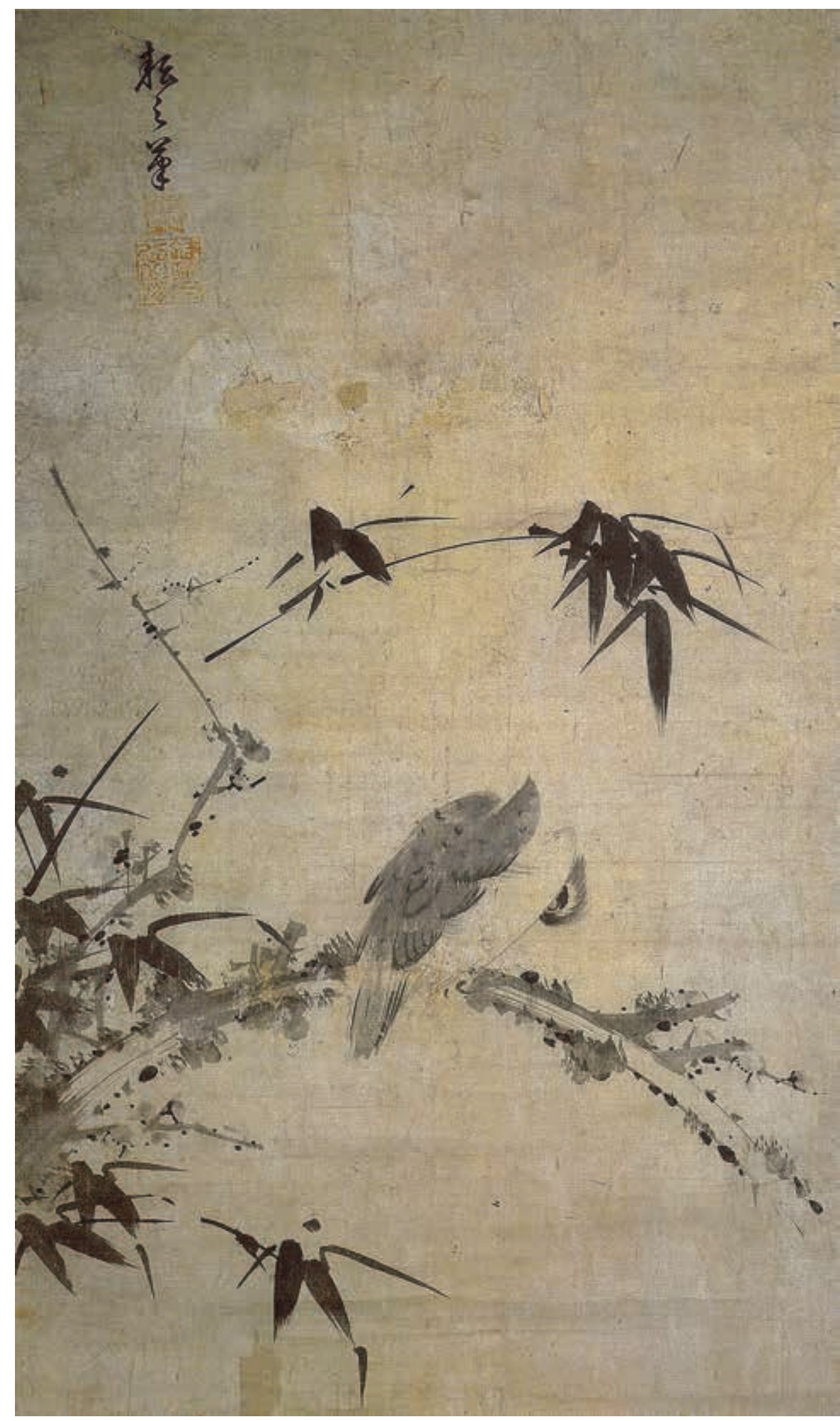

IIl. 5. Cho Jiun, Sleeping Bird on a Plum Tree, paper, ink, sumuk technique, $109 \times 56.3 \mathrm{~cm}$, the second half of the $17^{\text {th }}$ century, National Museum of Korea, Seoul

The task of such works was to make the bird the essence/ideological centre of the drawing. The background with a pair of rare freely scattered branches of soji (소지 疎枝) or a close landscape - p'yŏngakkyŏng / p'yŏngyŏng (편각경 偏角景 / 편경 片景 lit- erally "close, fragmented landscape"), only complemented, framed it.

The paintings of birds on thin branches, popularised by Kim Jŏng during the early Chosŏn period, largely copied or resembled the flying, singing, sleeping, and feeding birds from the Ming Dynasty painting albums, such as Gao Song's Painting Manual of Birds and Animals by Gao Song (Gao Song Lingmoapu 高松翎毛譜). We see similar birds in the paintings Bird Enjoying the Scent of Plum Blossom (매조문향도 梅鳥聞香圖）by Kim Si (김시 金禔 pseudonym Yangsongdang 양송당 養松堂, 1524-1593) from the Kansong Art Museum, Wild Bird and Bamboo (죽금도 竹禽圖) by Sin Serim (신세림 申 世霖, pseudonym Illim 인림 仁霖, 1521-1583), Lonely Bird on a Branch in Winter (한가독조도 寒柯獨鳥圖） by $\mathrm{Yi}$ Gyŏngyun (이경윤 李慶 胤, pseudonym Nakp'a 낙파 駱坡, 1545-1611) and Doves on a Willow in Spring (류상춘구도 柳上春鳩圖) by Yi Yŏngyun. The last three works are kept in the National Museum of Korea [6, p. 52].

The works of Cho Sok (조속 趙涑, pseudonym Ch'anggang 창강 滄江, 1595-1668) became the most popular hwajodos of this period. Cho Sok was a real munin (a Confucian scholar), an honourable man; his contemporaries respected him and highly appreciated his virtuoso mastery of the brush. Unfortunately, the 


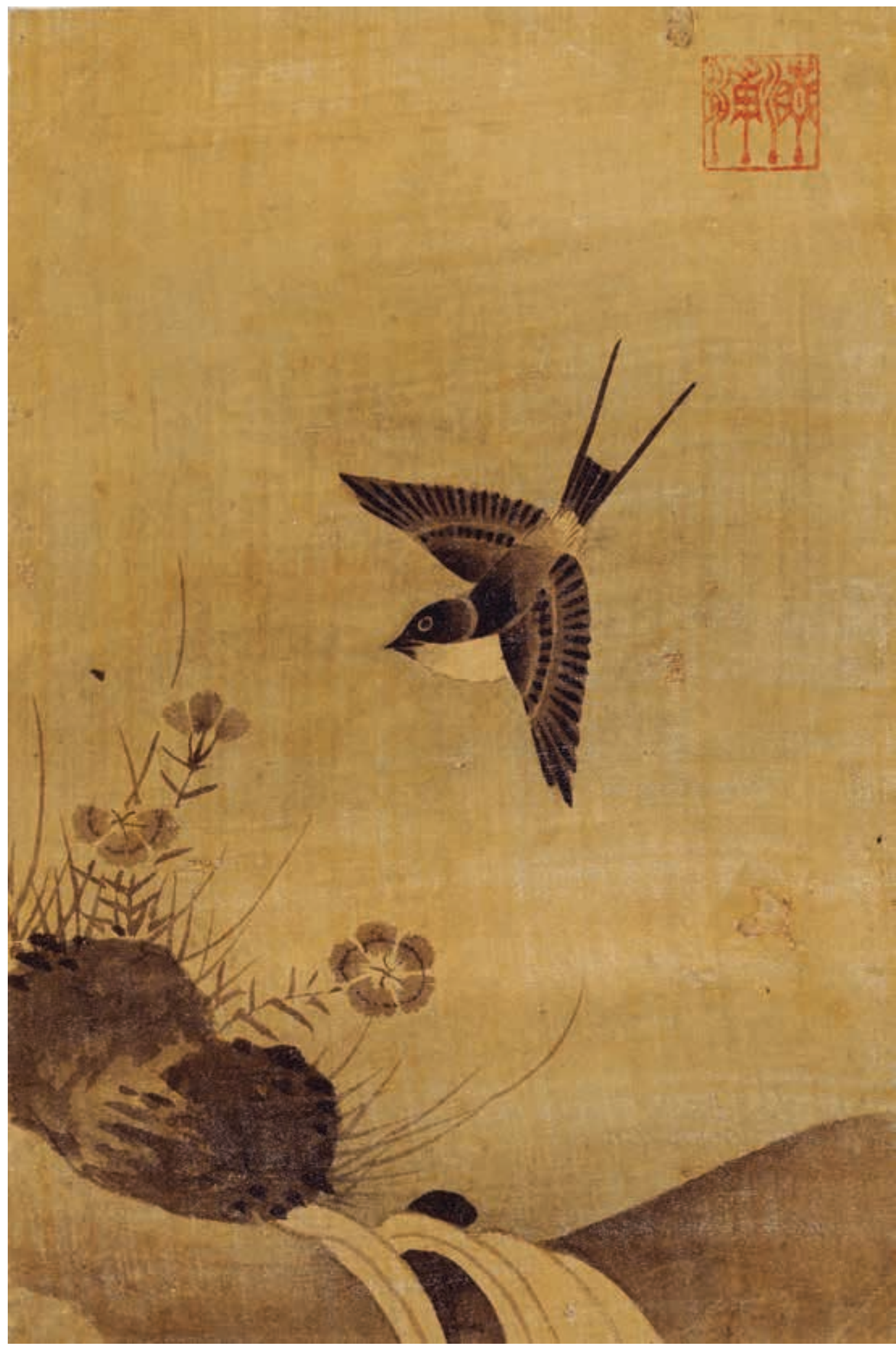

Ill. 6. Kim Sik, Flowers and Birds, silk, ink, tamch'ae technique (담채 淡彩 slight colouring of the depicted images and the background with paints and ink), $31.9 \times 20.5 \mathrm{~cm}, 17^{\text {th }}$ century, National Museum of Korea, Seoul

artist rarely left a signature or a stamp on his paintings, so only some works are attributed to Cho Sok.

His depiction of birds and triangular leaves arranged in a rhythmic mosaic pattern on a large silk scroll Magpies Living on an Old Tree (조작도 鳥鵲圖
/ 노수서작도 老 樹棲鵲圖) from the National Museum of Korea (Fig. 4) reveals similarities with the style of the famous Ming painter, Lin Liang（林良, 14281494). Nevertheless, this work is very Korean in spirit: since ancient times, in Korean beliefs, magpies have 


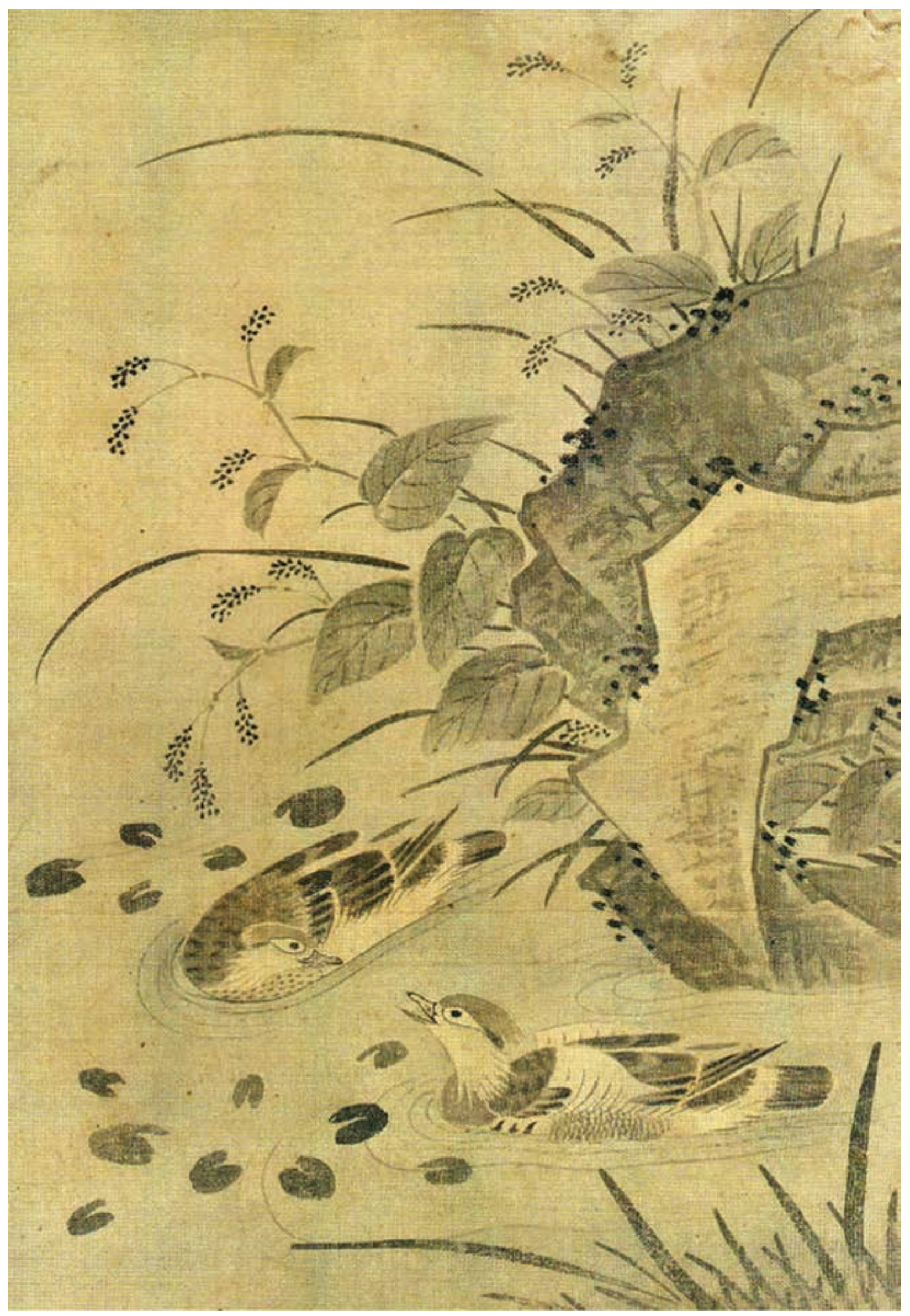

IIl. 7. Yi Jing, Mandarin Ducks in a Pond and Water Pepper, silk, ink, water paint, tamchkhe technique, $31 \times 21 \mathrm{~cm}$ the first half of the $17^{\text {th }}$ century, Kansong Art Museum, Seoul 
been messengers of good news [7, pp. 156-158; 11, pp. 113-115]. Also, the [Bearing Joy] Magpie on an Old Plum Tree (고매서작도 古梅瑞鵲圖) from the Kansong Art Museum perfectly demonstrates Cho Sok's painting technique: in the painting, a magpie, resting after the hardships of a long winter on a blossoming branch of an old plum tree, is painted using pibaekch'e lines (비백체 飛白體 literally: "flying white brush technique" or "flying white", a calligraphic style, which is characterised by fast brush movements with a small amount of ink, leaving unpainted places). In the lower part of the painting, transparent bamboo leaves are barely marked with a brush [9, pp. 64-69].

Using chop'il and pangp'il strokes, Cho Sok painted a lot of wild birds, working only with ink; such paintings were called mukkŭm (묵금 墨禽). The Sleeping Bird on a Moonlit Night (월야수금도 月夜睡禽圖) from the National Museum of Korea is a vivid example. This is a typified, very popular motif: a small bird sleeping in the branches and hiding its head on its chest is depicted. The semantic implications of such drawings are always the same - the bird is tired and resting after a long, hard winter; it is waiting for the imminent arrival of spring.

Cho Sok's son Cho Jiun (조지운 趙之耘, pseudonym - Maech'ang, Maegok 매창 梅空, 매곡 梅谷, 1637-1691?) and Yi Gŏn (이건 李健, pseudonym Kyuch'ang 규창 葵空, 1614-1662) with his Sleeping Bird on a Snowy Night (설월조몽 雪月鳥夢) from the Kansong Art Museum [6, p. 53] continued the tradition of minimalist ink painting of sleeping birds. The paintings Sleeping Bird (숙조도 宿鳥圖) from a private collection and Sleeping Bird on a Plum Tree (매상숙조도 梅上宿鳥圖) from the National Museum of Korea (Fig. 5) are examples of Cho Jiun's work.

It can be safely asserted that Cho Sok and Cho Jiun created a whole trend in Korean hwajohwa painting, which is characterised by the depiction of sleeping birds or lonely birds sitting on branches in light ink.

As we have already noted, the hwajodos described above with birds sitting on thin branches are often typical, schematic and depicted rather symbolically. However, there are paintings made in a more sophisticated, elegant manner, for example, White-headed Birds on Zanthoxylum (산초백두도 山椒白頭圖) and Little Birds on a Red Maple (단풍소조도 丹楓小鳥圖) by Yi Ham (이함 李涵, pseudonym - Ŭnho 은호 恩湖, 1633-?), kept in the National Museum of Korea.
In the middle Chosŏn period, in the sogyŏng yŏngmohwa painting (depicting animals and birds in micro-landscapes), along with the soji yŏngmoryu movement (animals and birds on branches), the p'yŏngyŏng yŏngmoryu movement (fragmented landscape with animals and birds) developed. In it, ink techniques and structural proportions, inherent in the Zhe school, were applied. It was clearly manifested in the works Waterfowl (수금도 水禽圖) by Yi Sunghyo (이숭효 李崇孝, the second half of the $16^{\text {th }}$ century ?-?) from a private collection, Birds on the Water in Summer (하정수금도 夏汀水禽圖) by Yi Gyŏngyun from the National Museum of Korea, as well as in the works of Kim Sik (김식 金埴 pseudonym - T'oech'on 퇴촌 退村, 1579-1662) and Yi Jing (이징 李澄, pseudonym - Hǒju 허주 虛舟, 15811653?) [6, p. 54].

Kim Sik's landscapes with birds, which are now kept in the National Museum of Korea (Fig. 6), were very popular among his contemporaries; they were painted in the "boneless" technique, molgolpŏp (몰골법 沒骨法), which involves painting with ink or mineral paints without drawing outlines. It is a whole series of paintings characterised by contrasting combinations of light and dark tones of ink, light colouring, delicate careful brush work depicting birds' plumage, and other details.

This technique was perfected by Yi Jing, a hereditary artist and the illegitimate son of Yi Gyŏngyun. Yi Jing's work became very popular at the court of King Injo (인조 仁祖, 1623-1649). The artist enjoyed royal patronage and worked extensively for the royal family.

Yi Jing's style and technique are reminiscent of the style and technique of Lü Ji, the master of the Ming Dynasty mentioned above. Works attributed to Yi Jing include Mandarin Ducks in a Pond and Water Pepper (요당원앙 苶塘鴐葬) from the Kansong Art Museum (Fig. 7). It is a small landscape in which a couple of ducks in love play in the water near the stones [10, p. 41]. The painting is distinguished by a bright contrast of light and shadow. The pointed stones are depicted using the pubyǒkchun technique (부벽준 斧䢃詖 "an axe notch", the chopped lines resemble the marks of an axe notch). Yi Jing used the "boneless" technique, detailing duck feathers, and carefully depicting aquatic plants using chŏmmyop'ung dots (점묘풍 點描風).

In the middle Chosŏn period, the restrained elegance of Cho Sok's works especially attracted educated people, officials and Confucian scholars; Yi 
Jing's more decorative painting was loved in the royal family and among aristocrats [6, p. 55].

It is worth emphasising that in the second half of the $16^{\text {th }}-17^{\text {th }}$ centuries, Korea experienced a difficult and troubled period in its history; the country suffered from internal turmoil and foreign invasions (Imjin war of 1592-1598, Manchurian invasion of 1627 and 1637). Although large idyllic compositions with vibrant flowers and birds continued to be painted by professional artists in response to orders from the Korean aristocracy, during this period, paintings by intellectual artists with lonely and weary birds sleeping or simply resting on tree branches became the leading movement in the hwajohwa genre, reflecting the inner mood and feelings of the educated stratum of Korean society about the fate of their homeland.

In conclusion, let us emphasise that there was active development of the bird-and-flower genre as an independent movement of Korean traditional painting in the early Chosŏn period. The artists perfected the basic academic styles and techniques, borrowing them from China and adapting them to their tastes and requests of the client. The hwajohwa movement quickly reached a high level of artistic maturity, depicting an ideal and beautiful natural world, and became one of the most popular and beloved movements in Korean society. In the middle Chosŏn period, the hwajohwa genre continued to develop. Its heyday occurred in paintings by intellectual artists, which is confirmed by the large number of paintings painted only in ink that have survived to this day. It is also important to note that during this period, Korean neo-Confucianism finally became the leading state ideology, which in turn contributed to the beginning of the gradual formation of vivid national characteristics in the culture of Chosŏn in general and in painting in particular. These national characteristics were already actively manifested in the $18^{\text {th }}$ century, in the late Chosonn period, and were reflected in the bird-and-flower genre.

\section{REFERENCES}

1. Vostrikova, E., Gavrilin, K., 2020. "The Pictorial Heritage of Shin Saimdang's oeuvre: historical context, the main genres, creative evolution", Decorative Art and Subjectspatial Environment. MGHPA Bulletin, Moscow: MGHPA, no. 3, part 1, pp. 66-82.

2. Dzharylgasinova, R. 1972. "Koguryŏ Tombs and Their Wall Paintings", Korean Classical Art. Collection of articles, ed. L. Kontsevich. Moscow: GRVL, pp. 15-29.

3. Kireeva, L. I. 2006. "Chang Sŭngŏp's Scroll in the LO INA Collection", Articles on Korean Art: a Collection of Selected Articles and Notes. Magnitogorsk: MAGU, pp. 32-35.

4. Kontsevich, L. 2001. Korean Studies: Selected works. Moscow: Muravei-Guide, p. 640.

5. Chistyakova, A. N. 2004. "On the Role of Birds in the Culture of China and Korea", Russian Korean Studies. Almanac. Moscow: Muravei. The $4^{\text {th }}$ edition, pp. 209-215.

6. Hong Sunpyo. 2008. "Hwajohwa of the Goryeo and Joseon Dynasties", The International Journal of Korean Art and Archeology. Seoul: National Museum of Korea, vol. 2, pp. 43-65.

7. Park Youngdae.2004. Essential Korean Art from Prehistory to the Joseon Period. Seoul: Heonamsa Publishing Co., p. 420.

8. 강명석, 리경수. 우리 민족의 옛 미술가들.-평양: 평양 출 판사, 2009. P. 303 쪽. (Kang Myŏngsŏk, Yi Gyŏngsu. Old Painters of Korea. Pyongyang: Pyongyang Ch'ulp'ansa, 2009. p. 303)

9. 백인산. 우리 문화와 역사를 담은 엣 그림의 아름다움. 간송미술 36_회화.- 서울: 컬처그라퍼, 2016.- 307 쪽. (Paek Insan. The Beauty of Ancient Paintings that Tell us About Korean Culture and History. 36 Masterpieces of the Kanson Art Museum. Seoul: K'olch'okŭrap'o, 2016. p. 307)

10. 화훼영모 - 자연을 품다.- 서울: 간송미술문화재단, 2015. P. 221 쪽. ("Flowers, Birds and Animals: a Reflection of Nature". Exhibition Album. Seoul: Kanson Misul Munhwachaedan, 2015. p. 221)

11. 최순우. 무량수전 배흘림기둥에 기대서서.- 서울: 학고 재, 2008. P. 519 쪽. (Ch'oe Sunu. Leaning on a Column in the Paehŭllim Technique from the Muryangsujŏng Pavilion. Seoul: Hakkojae, 2008. p. 519)

\section{List of electronic resources}

1. The Ewha Womans University Museum official website (이화여자대학교박물관): http://cms.ewha.ac.kr/user/ indexMain.action?siteId = museum

2. The Leeum Museum official website: http://www.leeum. org/html/global/main.asp

3. The Japanese Folk Museum in Tokyo official website (日本民藝館): https://www.mingeikan.or.jp

4. The Seoul National University Museum (서울대학교박 물관) official website: http://museum.snu.ac.kr

5. The National Museum of Korea (국립중앙박물관) official website: https://www.museum.go.kr/site/main/ home

6. The Jinju National Museum (국립진주박물관) official website: https://jinju.museum.go.kr

7. The Kansong Art Museum (간송미술관) official website: http://kansong.org 
Екатерина Александровна Вострикова

Сотрудник Международного центра корееведения Института стран Азии и Африки Московского государственного университета имени М. В. Ломоносова,

соискатель Кафедры истории искусств и гуманитарных наук Московской государственной художественно-промышленной академии имени С. Г. Строганова e-mail: dolihotella@hotmail.com

Москва, Россия

\section{ЖАНР ХВАДЖОХВА («ЦВЕТЫ И ПТИЦЫ») В КОРЕЙСКОЙ ТРАДИЦИОННОЙ ЖИВОПИСИ РАННЕГО И СРЕДНЕГО ПЕРИОДОВ ЧОСОН (КOHЕЦ XIV - КOHЕЦ XVII ВB.)}

Аннотация. Настоящая статья посвящена художественному жанру хваджохва («цветы и птицы») раннего и среднего периодов Чосон (конец XIV — конец XVII вв.). В исследовании обозначен историко-культурный контекст, а также стилевая эволюция жанра «цветы и птицы», выявлены основные термины для его обозначения, представлены отдельные художественные направления, рассмотрены техники и приёмы, применявшиеся в корейской традиционной живописи. Автор также очерчивает основной круг художников, работавших в данном жанре в обозначенный период.

Уже в ранний период Чосон (1392 - ок. 1550) жанр хваджохва занял особое место в традиционной корейской живописи и смог достичь высокого уровня художественной зрелости. Яркие картины в жанре «цветы и птицы», выполненные в академическом стиле придворной живописи, стали самыми распространёнными и показательными для данного исторического периода. В процессе становления и укрепления позиций новой династии Ли художники выполняли социальный заказ правящих кругов, поэтому произведениям свойственен оптимистический настрой, композиции полны идиллии и гармонии с окружающим миром. Самым ярким представителем этого направления был художник Ли Ам, который заложил основы развития жанра хваджохва в Корее. В это же время художники-интеллектуалы

В отечественном корееведении имеется ряд научных работ, в которых объектами исследования становились темы птиц и растений. Так, например, хорошо изучены космогонические мифы, где часто встречается мотив рождения из яйца антропоморфных предков, основателей древних начинают создавать небольшие пейзажи с птицами, выполненные только водой и тушью. Родоначальником этого живописного направления по праву считается учёный-конфуцианец Ким Джон.

Для среднего периода Чосон (ок. 1550-1700) характерен расцвет жанра хваджохва в технике монохромной живописи тушью. Появилось много художников-интеллектуалов из высших слоёв корейского общества, для которых жанр «цветы и птицы» стал средством выражения глубоких личных взаимоотношений с природой и миром вокруг. Корея второй половины XVI-XVII вв. страдала от многочисленных иноземных вторжений, поэтому одинокие и утомлённые птицы, спящие или отдыхающие на ветвях деревьев, стали основным и самым популярным мотивом в жанре хваджохва. Такая живопись была прямым отражением переживаний образованной прослойки корейского общества о судьбе родины. Самыми популярными произведениями жанра «цветы и птицы» этого периода стали картины художника-интеллектуала Чо Сока и придворного художника Ли Джина.

Ключевые слова: корейская традичионная живопись периода Чосон, жанр хваджохва («цеты и птицы»), Ю Джами, Ли Ам, Ким Джон, Син Саимдан, Ли Ёнъюн, Ли Джин, Чо Сок, Ким Сик, Ли Хам, Чо Джиун.

корейских государств [4, с. 436, 441, 449], тщательно описаны изображения птиц и растительного орнамента на знаменитых фресках в гробницах Когурё [2], существуют лингвистические исследования, связанные с животным и растительным миром [5]. Однако в российском искусствознании 
нет специальных работ, посвящённых жанру хваӘжохва («цветы и птицы») в корейской традиционной живописи, исключением является краткое описание свитка художника Чан Сынъопа «Дикие гуси» Л.И. Киреевой [3].

В представленной статье автор базируется на исследованиях южнокорейских учёных, в первую очередь профессора Хон Сонпхё [6], опираясь на предложенные им периодизацию и терминологию. В центре нашего внимания - основной круг художников, прославившихся в указанном живописном направлении, а также технические и стилевые особенности, характерные для жанра «цветы и птицы» рассматриваемых периодов.

История изображения цветов и птиц в Корее имеет глубокие корни. С древнейших времён в корейской культурной и художественной традиции, которая черпала свои истоки и развивалась в тандеме с китайской традицией, птицы, как божественные живые существа, были объектами поклонения и вдохновения. Они украшали собой разнообразные артефакты и использовались в качестве благопожелательных и призывных символов долголетия, богатой и обильной жизни, полной здоровья, почёта, удачи и любви, а также воплощали абсолютные принципы порядка и гармонии Природы. Изображения цветов и птиц привносили красоту и величие в королевские дворцы и дома знати, они стали очень популярны как картины, по сути, изображающие сцены рая.

В период Корё (918-1392 гг.), когда корейское искусство приобрело сложные и утончённые формы, началось формирование новой живописной традиции, и изображение цветов и птиц становится самостоятельным жанром. К сожалению, ни одно произведение в жанре «цветы и птицы» периода Корё до нас не дошло. Мы встречаем цветы и птиц только как элементы, включённые в картины прославленной буддийской религиозной живописи Корё.

Расцвет живописи хваджохва приходится на эпоху Чосон (правление династии Ли, 13921910 гг.) - это промежуток корейской истории протяжённостью в пятьсот лет. Ранний период Чосон условно датируется 1392-1550 гг., средний - 1550-1700 гг.

В Корее хваджо (хва) (화조(화) 花鳥 (畫) дословно «живопись цветов и птиц») как термин для обозначения художественного жанра, будучи заимствован из Китая, стал использоваться с XV в. в начале эпохи Чосон. Самый ранний корейский текст, который содержит этот термин, - «Записки о живописи» («Хваги», 화기 畫記), написанные Син Сукчу (신숙주 申叔舟, 1417-1475 гг.) в 1445 г. Однако существует ещё целый ряд терминов, синонимичных хваджо, именующих этот жанр: 4осучхомок (조수초목 鳥獸草木 птицы, животные, травы и деревья), хвамоккымджо (화목금조 花木 禽鳥 цветы, деревья и птицы) и хваджомоксок (화조목석 花鳥木石 цветы, птицы, деревья и животные) [6, с. 45]. Для обозначения изображений животных и птиц художественные альбомы китайской династии Мин (1368-1644 гг.) использовали термин линмао (邻毛 «мех и перья», кор. ёнмо 영모), он стал широко использоваться в средний период Чосон, как и включавшие его термины хвахвеёнмо (화훼영모 花卉领毛 цветы, птицы и животные) и хвачхоёнмо (화초영모 花草领毛 цветы, травы, птицы и животные).

В статье используются термины хваджохва как обозначение жанра «цветы и птицы» и хваджодо (화조도 花鳥圖), обозначающий картины, выполненные в этом жанре. Важно подчеркнуть, что акцент данного исследования сделан именно на картинах с птицами и растениями, а не животными, которые тоже включаются в жанр.

\section{Хваджохва в ранний период Чосон (1392 - ок. 1550)}

Жанр хваджохва стал занимать особое место в традиционной корейской светской живописи и достиг высокого уровня художественной зрелости уже в ранний период Чосон. Реалистическая живопись в стилистических направлениях курыкчончхэпхун (구륵전채풍 鉤勒塡彩風 контур изображаемых объектов выполняется тушью и осуществляется заливка цветом внутри контура) и мольгольчхэсэкпхун (몰골채색풍 沒骨彩色風 «бескостная» живопись тушью и минеральными красками выполняется без нанесения контура) была официально распространена и применялась на практике в среде придворных художников хвавонов (화원 畫員) Академии живописи Тохвасо (도화서 圖畫暑), которые удовлетворяли возросшие художественные запросы королевской семьи.

В соответствии со «Сводом ритуалов» («Еджон» 예전 禮典) «Великого уложения по управлению государством» («Кёнгук тэджон» 경국대 전 經國大典 окончательно оформилось к 1485 г.) существовала система отбора и экзаменования 
придворных художников чхвиджэ (취재 取材) [6, с. 49]. На экзаменах изображению цветов и птиц, также, как и изображению человеческих фигур, было отведено третье место по значимости (первое занимал бамбук, второе - пейзаж).

Для королевской семьи придворные художники в точной реалистической манере часто создавали изображения сокола, именуемые хэчхондо (해청도 海靑圖), писали к Новому году специальные картины в жанре сэхва (새화 歲畫), которые ван (корейский король) дарил родственникам и высокопоставленным чиновникам по случаю праздника, например, чхуынпактходо (추응박토 도 秋鷹搏鬼圖) - изображение сокола, охотящегося на кролика осенью.

В то же время высшая прослойка корейского средневекового общества садэбу (사대부 士大夫), выходцы из которой наряду с правящей семьёй были основными заказчиками и покровителями искусств, видела в хваджохва символ гармонии с природой канхоханджон (강호한정 江湖閒靜 тишина/спокойствие на лоне природы) и превосходства над всем мирским [6, с. 49].

На картинах в жанре хваджохва чаще всего изображались следующие птицы: утки, белые цапли, журавли, соколы, дикие гуси, ласточки, чайки, воробьи, сороки, голуби, иволги, павлины, петухи и курицы. Они писались в разных положениях на фоне цветов, трав, бамбука, деревьев или камней.

Все картины хваджодо периода Чосон корейские искусствоведы условно разделяют на два основных живописных стиля. Первый - рисование тушью и водяными красками чхэмукпхун (채묵풍 彩墨風). На картинах в стиле чхэмукпхун птицы писались мелкими движениями кисти, аккуратными линиями цветом и тушью на фоне пейзажа тэгён (대경 大景 дословно «большой пейзаж») с деревьями в верхней части полотна и водой или камнями в нижней. Стиль чхэмукпхун в ранний период Чосон развивался на основе живописи Корё, также на него влияли реалистические декоративные традиции, присущие академическим школам живописи ранней династии Мин.

Сохранилось совсем мало корейских картин, выполненных в китайских академических техниках живописи, - это «Сосны и журавли в долине» (지곡송학도 芝谷松鶴圖) Ю Джами (유자미 柳自湄, творческий псевдоним (далее псевд.) Сосан 서산 西山,?-1462) из Музея Кансон [10, с. 19-21], четыре картины «Цветы и птицы» (рис. 1) Син Джама
(신잠 申潛, псевд. Ёнчходжа 영천자 靈川子, 14911554 гг.) и одна работа Ан Гвисэна (안귀생 安貴生, конец XV в.,?-?) из Национального музея Кореи.

Также до нас дошёл цикл с цветами, птицами, кошкой, собакой и щенками прославленного художника Ли Ама (이암 李嚴, псевд. Чонджун 정 중 靜仲, 1499-1566?). Одна картина этого цикла хранится в Национальном музее Кореи, одна в Национальном музее Чинджу, одна - в музее Лиум, две - в Художественной галерее Пхеньяна и еще одна - в Музее народного творчества Японии в Токио. Также сохранился свиток Ли Ама «Пара диких гусей» (한쌍의 기러기) из Художественной галереи Пхеньяна (рис. 2) [8, с. 77-82].

На упомянутых выше картинах изображень разнообразные птицы или животные, деревья, растения, цветы, камни, холмы и горы в разные времена года в стиле живописной школы Чжэ (浙派 чжэ пай), или Чжэцзянской школы династии Мин, для которой характерны двухмерность, декоративная плоскостность, асимметричная композиция, усиленный контраст светлого и тёмного, комбинирование реалистичных и декоративных элементов, часто напоминающих абстрактный орнамент, выполненный тушью и водяными красками.

Наибольшее влияние на корейскую живопись хваджохва раннего периода Чосон оказал Люй Цзи (呂紀 1477?-1505?), признанный китайский мастер придворной академической живописи, работавший в жанре «цветы и птицы». Этому художнику подражал Ан Гвисэн, его же технические приёмы использовал Син Джам, но наиболее ярко они отражены в картинах Ли Ама [6, с. 50]. Интересно, что Ли Ам был выходцем из королевской семьи. Принято считать, что созданный им яркий, лирический, идеальный живописный мир заложил основы развития хваджохва в Чосоне.

Второе заметное стилевое направление - сумукпхун (수묵풍 水墨風), писание водой и тушью, монохромная живопись тушью. Картины в стиле сумукпхун - это близкий микропейзаж согён (소 경 小景 дословно «маленький пейзаж»), на котором изображалась одна или две птицы одного биологического вида. Сумукпхун с его тяготением к импровизированности и нарушению академических канонов вырос как новый самостоятельный стиль из мукхи (묵희 墨戯) — «игры тушью», ассоциировавшейся как в Китае, так и в Корее с живописью художников-любителей мунинов (문인 文人 учёные-конфуцианцы, интеллектуалы) и художников чань-буддистов. 
Небольшие работы тушью согён обычно были двух типов. На картинах первого типа писались одна или две птицы, сидящие на длинной, иногда цветущей ветви чольджи (절지 折枝 ветвь без изображения ствола) [6, с. 50]. Чаще всего изображались трясогузки, большие синицы, бекасы, сороки на ветвях сливы или бамбука. Они выполнялись резкими динамичными мазками чопхиль (조필 粗筆 грубая/жесткая кисть) и панпхиль (방필 放筆 свободная кисть, техника «свободной руки»). Картинам присуща лапидарность, это так называемая «живопись идеи» саыйчхе (사 의체 寫意體), стремящаяся не столько к точной передаче образа, сколько к выражению его сущности, сути, духа в смелых свободных росчерках кисти. Второй тип - пейзаж с камнями, скалами, водными растениями, находящимися у кромки водоёма, в котором часто изображались цапли, водоплавающие птицы или птицы, обитающие у воды. Картины этого типа схожи с небольшими пейзажами династии Южная Сун (1127-1279 гг.) и пейзажами в стиле школы Чжэ династии Мин, для них характерна композиция пёнгак (변각 邊 角) - сосредоточенность всех основных объектов изображения в одном углу [6, с. 51].

До нас дошло мало работ направления сумукпхун раннего периода Чосон. В этом стиле работал художник-интеллектуал Ким Джон (김정 金淨, псевд. Чхунам, Кобон 충암 冲荑, 고봉 孤峯, 1486-1521 гг.), сохранились его картины «Белоголовые птички на ксантоксилуме» (산초백두 山 椒白頭) $и$ «Птичка на тонкой ветке» (영모절지도 领毛折枝圖）из частных коллекций и две работы «Цветы и птицы» (화조도 花鳥圖) из Художественной галереи Пхеньяна (рис. 3).

Также сохранились картины единственной женщины-художника периода Чосон Син Саимдан (신 사임당 申師任堂, 1504-1551 гг.): «Белые цапли» (백 로도 白鷺圖) из Музея Сеульского национального университета, «Белая трясогузка» (알락할미새) из Музея Женского университета Ихва и «Пара уток-мандаринок» (원앙도 鴐鴿圖) из частной коллекции. Это прекрасные примеры небольших пейзажей, выполненных на досуге для «саморадости» [1, с. 70-71]. Такие работы призваны внушать чувство спокойствия и гармонии с природой, они не изображают птиц и окружающий их живой мир с анатомической точностью.

В Национальном музее Кореи хранится хваджодо художника раннего периода Чосон Ли Джонждуна (이종준 李宗準, псевд. Ёнджэгон 용재공 慵
齋公,?-1499) «Журавль на сосне» (송학도 松鶴圖). Это некий промежуточный вариант между двумя рассмотренными направлениями. Журавль, стоящий на толстой ветви сосны, написан тушью, но в работу небольшим акцентом добавлен цвет.

Подводя промежуточные итоги, отметим, что в ранний период Чосон происходило становление новой династии и укрепление её правящего авторитета. Для жанра «цветы и птицы», как и для всей корейской живописи этого исторического периода, характерен оптимистический настрой, художники создают композиции, полные идиллии, пишут гармоничный и прекрасный мир под небесами, выполняя социальный заказ правящих кругов, или удовлетворяя свои творческие амбиции.

\section{Хваджохва в средний период Чосон (ок. 1550-1700)}

В средний период Чосон живопись хваджохва достигла своего наивысшего расцвета. Учёные мужи видели в полёте и пении птиц олицетворение рая, чистого удовольствия, квинтэссенцию основополагающей правды космологического движения всего сущего [6, с. 52]. Жанр «цветы и птицы» стал средством выражения глубоких личных взаимоотношений человека с природой. В этот период появилось много художников-интеллектуалов из высших слоёв корейского общества, которые принадлежали к королевскому двору или были чиновниками.

Такие художники, как Юн Ом (윤엄 尹晸, псевд. Сонъам 송암 松裖, 1536-1581 гг.) и Ли Ёнъюн (이 영윤 李英胤, псевд. Чуннимсу 죽림수 竹林守, 15611611 гг.), продолжали создавать типичные двухмерные большие хваджодо в академическом стиле, подобные тем, что писались в ранний период Чосон.

Однако самыми многочисленными, популярными и показательными хваджодо среднего периода Чосон стали небольшие рисунки птиц, выполненные только водой и тушью. Задача таких произведений - сделать птицу сутью/идейным центром рисунка, а фон из пары редких свободно разбросанных ветвей соджи (소지 疎枝) или близкого пейзажа пхёнгакгён/nхёнгён (편각경 偏角景 / 편경 片景 дословно «близкий, фрагментированный пейзаж») только дополняет, обрамляет её.

Картины с изображением птиц на тонких ветвях, популяризированные Ким Джоном ещё в ранний период Чосон, во многом копировали или 
напоминали летящих, поющих, спящих и кормящихся птиц из альбомов живописи династии Мин, таких как «Руководство по изображению птиц и животных Гао Суна» («Гао Сун линмоапу» 高松领毛譜). Мы встречаем подобных птиц на картинах «Птичка наслаждается ароматом цветущей сливы» (매 조문향도 梅鳥聞香圖) работы Ким Cи (김시 金禔, псевд. Янсондан 양송당 養松堂, 1524-1593 гг.) из музея Кансон, «Дикая птица и бамбук» (죽금도 竹 禽圖) Син Серима (신세림 申世霖, псевд. Иллим 인 림 仁霖, 1521-1583 гг.), «Одинокая птица на ветке зимой» (한가독조도 寒柯獨鳥圖) Ли Гёнъюна (이경 윤 李慶胤, псевд. Накпха 낙파 駱坡, 1545-1611 гг.) и «Голуби на иве весной» (류상춘구도 柳上春鳩 圖) Ли Ёнъюна - три последних работы хранятся в Национальном музее Кореи [6, с. 52].

Самыми популярными хваджодо этого периода стали произведения Чо Сока (조속 趙涑, псевд. Чханган 창강 滄江, 1595-1668 гг.). Чо Сок был настоящим мунином (учёным-конфуцианцем), благородным мужем, современники уважали его и высоко ценили виртуозное владение кистью. К сожалению, художник редко оставлял подпись или печать на картинах, поэтому некоторые произведения только приписываются Чо Соку.

Его изображение птиц и треугольных листьев, расположенных в ритмичном мозаичном порядке, на большом шёлковом свитке «Сороки, живущие на старом дереве» (조작도 鳥鵲圖 / 노수서 작도 老樹棲鵲圖) из Национального музея Кореи (рис. 4) обнаруживает сходство со стилем прославленного минского художника Линь Ляна (林 良, 1428-1494 гг.). Тем не менее данное произведение очень корейское по своему духу: сороки издревле в корейских верованиях были вестницами хороших новостей [7, с. 156-158; 11, с. 113115]. «[Приносящая радость] сорока на старой сливе» (고매서작도 古梅瑞鵲圖) из Музея Кансон также прекрасно демонстрирует технику живописи Чо Сока: на картине с помощью линий пибэкчхе (비백체 飛白體 дословно «техника летящей белой кисти» или «летящий белый», каллиграфический стиль, которому присущи быстрые движения кисти с малым количеством туши, оставляющие незакрашенные пустоты) написана сорока, которая отдыхает после лишений долгой зимы на зацветшей ветви старой сливы. В нижней части картины кистью едва намечены прозрачные листья бамбука [9, с. 64-69].

Используя мазки чопхиль и панпхиль, Чо Сок много писал диких птиц, работая только тушью, такие картины назывались муккым (묵금 墨禽). Яркий пример - «Спящая птица лунной ночью» (월야수금도 月夜睡禽圖) из Национального музея Кореи. Это типизированный, очень популярный мотив: изображена небольшая, спящая в ветвях птица, спрятавшая голову на груди. Смысловой подтекст таких рисунков всегда одинаковый птица устала и отдыхает после длинной, тяжелой зимы, она ждёт скорого прихода весны.

Традицию минималистического изображения спящих птиц тушью продолжили сын Чо Сока Чо Джиун (조지운 趙之耘, псевд. Мэчхан, Мэгок 매창 梅空, 매곡 梅谷, 1637-1691?), примерами работ которого служат картины «Спящая птица» (숙조 도 宿鳥圖) из частной коллекции, «Спящая птица на сливе» (매상숙조도 梅上宿鳥圖) из Национального музея Кореи (рис. 5), и Ли Гон (이건 李 健, псевд. Кючхан 규창 葵空, 1614-1662 гг.) с его «Спящей птичкой снежной ночью» (설월조몽 雪 月鳥夢) из Музея Кансон [6, с. 53].

Можно смело утверждать, что Чо Сок и Чо Джиун создали целое направление в корейской живописи хваджохва, для которого характерно изображение светлой тушью спящих птиц или одиноких птиц, сидящих на ветвях.

Описанные выше хваджодо с птицами, сидящими на тонких ветках, как мы уже отмечали, часто типичны, схематичны и переданы довольно условно, однако встречаются картины, выполненные в более утончённой, элегантной манере, например, «Белоголовые птички на ксантоксилуме» (산초백두도 山椒白頭圖) и «Маленькие птички на красном клёне» (단풍소조도 丹楓小鳥圖) Ли Хама (이함 李涵, псевд. Ынхо 은호 恩湖, 1633-?), хранящиеся в Национальном музее Кореи.

В средний период Чосон в живописи согён ёнмохва (изображение животных и птиц в микропейзажах) наряду с направлением соджи ёнморю (животные и птицы на ветвях) развивалось направление пхёнгён ёнморю (фрагментированный пейзаж с животными и птицами), в котором применялись техники работы тушью и структурные пропорции, присущие школе Чжэ. Оно ярко проявилось в работах «Водоплавающие птицы» (수금도 水禽圖) Ли Сунхё (이숭효 李崇孝, вторая половина XVI в.,?-?) из частной коллекции, «Птицы на воде летом» (하정수금도 夏汀水禽圖) Ли Гёнъюна из Национального музея Кореи, а также в работах Ким Сика (김식 金埴, псевд. Тхвечхон 퇴촌 退村, 1579-1662 гг.) и Ли Джина (이징 李 澄, псевд. Ходжу 허주 虛舟, 1581-1653?) [6, с. 54]. 
Большой популярностью у современников пользовались пейзажи с птицами Ким Сика, которые сегодня хранятся в Национальном музее Кореи (рис. 6), выполнены они в «бескостной» технике мольгольпоn (몰골법 沒骨法), предполагающей писание тушью или красками минерального происхождения без нанесения контуров. Это целая серия картин, для которых характерны контрастные сочетания светлого и тёмного тона туши, лёгкое окрашивание, тонкая тщательная работа кистью в передаче оперения птиц и других деталей.

Данная техника была отточена Ли Джином, потомственным художником, незаконнорожденным сыном Ли Гёнъюна. Творчество Ли Джина стало очень популярным при дворе вана Инджо (인조 仁祖, 1623-1649 гг.), художник пользовался монаршим покровительством и много работал для королевской семьи.

Стиль и техника Ли Джина напоминают стиль и технику Люй Цзи, упомянутого выше мастера династии Мин. Среди работ, приписываемых Ли Джину, «Утки-мандаринки в пруду и водяной перец» (요당원앙 蓼塘鴛鶏) из Музея Кансон (рис. 7). Перед нами небольшой пейзаж, на котором пара влюблённых уток играет в воде около камней [10, с. 41]. Картину отличает яркий контраст света и тени. Заострённые камни изображены в технике пубёкчун (부벽준 斧辟皴 《насечка топором», рубленые линии напоминают следы от насечки топора). Ли Джин использует «бескостную» технику, детально прорисовывая перья уток, тщательно изображает водяные растения с помощью точек чоммёпхун (점묘풍 點描風).

В средний период Чосон сдержанная элегантность работ Чо Сока особенно привлекала образованных людей, чиновников и учёныхконфуцианцев, более декоративная живопись Ли Джина была любима в королевской семье и в среде аристократов [6, с. 55].

Стоит подчеркнуть, что Корея второй половины XVI-XVII вв. переживала непростой и смут- ный период в своей истории, страна страдала от внутренних неурядиц и иноземных вторжений (Имджинская война 1592-1598 гг., Маньчжурские вторжения 1627 г. и 1637 г.). Хотя большие идиллические композиции с яркими цветами и птицами продолжали писаться художникамипрофессионалами в ответ на заказы корейской аристократии, но в данный период картины художников-интеллектуалов с одинокими и утомлёнными птицами, спящими или просто отдыхающими на ветвях деревьев, стали основным и самым популярным направлением в жанре хваджохва, отражая внутренний настрой и переживания образованной прослойки корейского общества о судьбах родины.

Подводя итоги, ещё раз подчеркнём, что в ранний период Чосон происходило активное становление жанра «цветы и птицы» как самостоятельного направления корейской традиционной живописи. Художники оттачивали основные академические стили и техники, заимствуя их из Китая и адаптируя под свои вкусы и запросы заказчика. Направление хваджохва быстро достигло высокого уровня художественной зрелости и, изображая идеальный и прекрасный мир природы, стало одним из самых популярных и любимых в корейском обществе. В средний период Чосон жанр хваджоха продолжал развиваться, расцвет его произошёл в живописи художниковинтеллектуалов, что подтверждается большим количеством сохранившихся до наших дней картин, выполненных только тушью. Также важно отметить, что в этот период корейское неоконфуцианство окончательно стало ведущей государственной идеологией, что в свою очередь способствовало началу постепенного формирования ярких национальных особенностей в культуре Чосона в целом и в живописи в частности. Эти национальные особенности активно проявятся уже в XVIII в. в поздний период Чосон и найдут своё отражение в жанре «цветы и птицы».

\section{БИБЛИОГРАФИЯ}

1. Вострикова Е. А., Гаврилин К.Н. Живописное наследие Син Саимдан: исторический контекст, основные жанры, вопросы творческой эволюции // Декоративное искусство и предметно-пространственная среда. Вестник МГХПА / М.: МГХПА. — 2020. — № 3. Часть 1.- С. 66-82.
2. Джарылгасинова Р.Ш. Когурёские гробницы и их настенная живопись // Корейское классическое искусство. Сб. ст. под ред. Л.Р. Концевича.-М.: ГРВЛ, 1972. - С. 15-29.

3. Киреева Л.И. Свиток Чан Сынопа в собрании ЛО ИНА // Статьи по искусству Кореи: сборник 
избранных статей и заметок. - Магнитогорск: МаГУ, 2006. - C. 32-35.

4. Концевич Л.Р. Корееведение: Избр. работы / Л. Р. Концевич. - М.: Муравей-Гайд, 2001. - 640 с.

5. Чистякова А. Н. О роли птиц в культуре Китая и Кореи // Российское корееведение. Альманах. - М.: «Муравей». - 2004. - Выпуск четвертый. - С. 209215.

6. Hong Sunpyo. Hwajohwa of the Goryeo and Joseon Dynasties // The International Journal of Korean Art and Archaeology. Seoul: National Museum of Korea, Vol. 02, 2008. - P. 43-65.

7. Park Youngdae. Essential Korean Art from Prehistory to the Joseon Period. Seoul: Heonamsa Publishing Co., 2004. - 420 p.

8. 강명석, 리경수. 우리 민족의 옛 미술가들. 一 평양: 평양 출판사, 2009. - 303쪽. (Кан Мёнсок, Ли Кёнсу. Старые художники Кореи. - Пхеньян: Пхёньян чхульпханса, 2009. - 303 с.)

9. 백인산. 우리 문화와 역사를 담은 엣 그림의 아름다움. 간송미술36_회화.— 서울: 컬처그라퍼, 2016.— 307 쪽. (Пэк Инсан. Красота старинных картин, повествующих нам о корейской культуре и истории. 36 шедевров музея Кансон.- Сеул: Кхольчхокырапxo, 2016. - 307 c.)

10. 화훼영모 - 자연을 품다. - 서울: 간송미술문화재단, 2015. - 221쪽. (Цветы, птицы и животные - отра- жение природы: Альбом к выставке.-Сеул: Кансон мисуль мунхвачэдан, 2015. - 221 с.)

11. 최순우. 무량수전 배흘림기둥에 기대서서.-서울: 학고 재, 2008. - 519쪽. (Чхве Суну. Опираясь на колонну в технике пэхыллим из павильона Мурянсуджон.Сеул: Хаккоджэ, 2008. - 519 с.)

\section{Список электронных ресурсов}

1. Официальный сайт Музея Женского университета Ихва (이화여자대학교박물관): http://cms.ewha.ac.kr/ user/indexMain.action?siteId=museum

2. Официальный сайт Музея Лиум (Leeum 미술관): http://www.leeum.org/html/global/main.asp

3. Официальный сайт Музея народного творчества Японии в Токио (日本民藝館): https://www.mingeikan. or.jp

4. Официальный сайт Музея Сеульского национального университета (서울대학교박물관): http://museum. snu.ac.kr

5. Официальный сайт Национального музея Кореи (국 립중앙박물관): https://www.museum.go.kr/site/main/ home

6. Официальный сайт Национального музея Чинджу ( 국립진주박물관): https://jinju.museum.go.kr

7. Официальный сайт Художественного музея Кансон (간송미술관): http://kansong.org 
Petr P. Kozorezenko

Ph.D. in Art History,

Honored Artist of the Russian Federation

Professor,

Head of the Art of Graphics Department

Stroganov Moscow State Academy of Industrial and Applied Arts

e-mail: 7245631@mail.ru

ORCID 0000-0001-8949-6249

DOI: 10.36340/2071-6818-2021-17-2-79-100

\section{THE IMAGE OF THE ICON IN THE WORKS OF THE SEVERE STYLE ARTISTS}

Summary: The appeal to the artistic traditions of different eras - peculiar perception of the techniques of post-impressionism, the heritage of the Russian avantgarde, the search of the Soviet painters of the 1920s-1930s, as well as the art of Proto-Renaissance and Ancient Rus, became an important impetus to the creativity of the severe style artists. With artistic experiments and active use of various graphic lines, they skillfully combined the experience of ancient Russian art in their works; they used the icon and fresco painting traditions and primitivism painting together with modern patterns.

Ancient Russian art and its primary embodiment the icon, became the latent, not obvious dominant of the art of the severe style masters. The works of outstanding icon painters of the past (Theophanes the Greek, Andrei Rublev, Dionisius), who embodied a new, sublime understanding of man's spiritual beauty and moral strength in their works, were the pinnacle of skill for representatives of this art movement.

In Russian icons, the severe style artists were attracted by local colours, simplified composition and forms, and a "frozen" plot. They were even more attracted by their colour saturation, joyful power or harshness of pure colours. However, the connection with icon painting is not

The cardinal metamorphoses of the spiritual and moral life of the people during the Eastern Front of World War II marked the beginning of a new stage in artists' artistic practice, sharpened their susceptibility to hidden elements and trends of reality.

The search led to the approval of a new hero a contemporary creator, self-collected, demonstrating the firmness of moral principles, ready for work and struggle. Self value of a living person, freed only in the technical aspects of painting. In the works of the severe style artists, as in the icon, emotional stress is focused on the inner life and is not expressed by external exaltation.

The appeal to icon painting was not accidental: the artists felt the sad disappearance of the connection between generations, the tragic breakdown of age-old foundations, godlessness and... desperate longing for some other, unearthly Truth. All the complexity of the internal self-determination of the generation of the 1960s-1970s is seen in these voices of the era. The severe style representatives tried to reveal the theme of Light and Meaning, as much as possible in the conditions of Soviet times. Their paintings showed the truth of this search.

The severe style, a phenomenon that was so categorically assigned the status of something episodic, even fleeting, turned out to be compatible in different versions with philosophical and religious postulates that have been relevant at all times, with the national idea, with an attraction to eternity.

Keywords: severe style, Russian icon, religious plot, ascetic faces, moral strength, truth of life, Popkov, Nikonov, Korzhev.

from ideological husks, led artists to develop the theme of a person and his or her place in the modern world. Young masters wanted to show the hero of everyday work in close-up in typical circumstances of their time.

In painting, a new specific way of revealing the hero's inner world was indicated in the concealment of spiritual energy and potential in a laconic form. The essence was conveyed through the search for 
the relationship between the external appearance and the internal state of a person. A new interpretation of space and time appeared; the works began to differ in the breadth of ideological generalisations. The common goal, which brought together a large group of artists, gave rise to a commonality of aesthetic principles and formal techniques and was later conventionally called the severe style.

The artists felt the deterioration of the "old" technical means and compositional systems, denying the passivity of the "ceremonial" works of art. Therefore, they turned to the search for new artistic techniques that could arouse interest and involve the viewer in a fascinating process of searching for the spirit of the times and affirmation of the renewed person, trying to push to empathise with the content of their work. In the works of the future severe style artists - P. Ossovsky's At the Crossing, G. Korzhev's In the Days of War and V. Stozharov's Off For the Wood, which were presented at the first youth exhibition, art critics and viewers felt a change in the intonation structure in the perception of the surrounding reality - restraint, concentration, laconicism, authenticity.

A unique life experience, intolerance of lies, a creative principle, a meaningful approach to creativity, a strong civic position and fearlessness were the leading qualities of the generation. The artists did not break ties with the previous heritage. By isolating all the most valuable, ideologically clean, they put together new art from these components, giving their moral assessment of modernity and recent history. They wanted to have their say and be heard; thus, everyone fought for their creativity to the end.

In an attempt to grasp the nerve of the time, the severe style artists went to "document" reality in the corners of the country with harsh nature. The search for a real person, working under challenging conditions, spending every day in the fight against the elements, began to dictate its new pictorial language: a disregard for the beauty of nature, conventionality and graphicality of its image, restrained colour, monumental-poster laconic forms, a special type of heroes and internal emotional saturation in paintings (energy, restraint, audacity, overcoming, drama), the epic perception of the scenes presented by an artist.

Artists of the severe style sought to oppose their work to the semi-official pathos of the poster and the official imperial side of socialist realism. Already in the context of their early work, parameters of the severe style such as the depiction of unadorned reality, a departure from the detailed literary narration, the desire for a psychological interpretation of images, the metaphor of the artistic language, expanding the semantic boundaries of the work, were gradually developed.

This disarming unpretentiousness acted stronger than the boring cliché images of a "creative person". Moreover, it had its life authenticity since an artist's existence consisted of such ordinary situations, quite everyday, but at the same time filled with a secret inner life, miraculously resolved by works of art.

The theme of everyday work, the poeticisation of a person's daily work were the focus of the severe style artists. The most prosaic and mundane became the subject of monumentalisation and proud exaltation. Their characters were people of brutal professions - builders, geologists, repairmen, raftsmen, polar explorers. They had individual portrait features and formed a collective image of a courageous hero. Everything in these characters spoke of their difficult life, perseverance, spiritual and physical strength.

The new style demonstrated the Protestant type of hero - a responsible adult, with his or her own experience, personal faith and generally developed internal motivation (and therefore, without the need of external ideological stimulation from the party), although acting within the framework of a general transformation project. The artists were able to look around for a while, understand the time and themselves, escape from the insulting falseness of Soviet ideological and educational rituals, from the capital's showcases of communist prosperity into the inner world of the common man.

The artists were more absorbed in reflecting the inner, spiritual work of the characters than in describing the reality around them. Most of all, in the interpretation of the external appearance of the heroes, artists paid attention to the faces and hands of the characters since it is they and their interaction that manifest the inner state of a person. Although sometimes not the faces of individual people but the spiritualised face of a whole generation was portrayed in the works of the severe style artists.

In accordance with their understanding of the world and the general impression of emotional tension, the severe style artists chose artistic means as well. In search of the "truth of life", artists P. Nikonov, V. Popkov, G. Korzhev, brothers A. and P. Smolin, 
P. Ossovsky and others turned to a restrained, conventional, generalised form, rejecting any descriptiveness. Often, artists worked with large planes, used rigid plastic formulas, enlarged and flattened the image. The works are characterised by such artistic features as laconism, rhythmic, but balanced and monumentalized, predominantly frontally deployed composition with sharp linear rhythms, clear outlines of contours, constructive moulding of form, expressiveness, colouristic restraint with lapidary colour spots. Like the whole atmosphere of their paintings, colour emphasised the severity of the theme and images of the heroes, accentuated asceticism and spiritual saturation, depth. The paintings are dominated by shades of black, brown, earthy colours and other minor tones. Close-ups, provoking gazing at the heroes, were used. These paintings are very close to the pictorial traditions of Old Russian icons and early Russian "personal" portraits of the $17^{\text {th }}$ century.

The appeal to the artistic traditions of different eras - their peculiar perception of the techniques of post-impressionism, the heritage of the Russian avant-garde, the search of the Soviet painters of the 1920s-1930s, as well as the art of Proto-Renaissance and Ancient Rus, was an essential impetus to the creativity of the severe style masters. With artistic experiments and active use of various graphic lines, they skillfully combined the experience of ancient Russian art in their works; they used the icon and fresco painting traditions, primitivism painting together with modern patterns.

The artists were inspired by masterpieces of the past centuries. They seemed to be in a constant internal dialogue with the masters, whose heritage had been a source of fruitful ideas in Russian pictorial culture for centuries and could not be destroyed in several decades.

Studying the work of masters of the past significantly expanded the stylistic and thematic boundaries of the work of Soviet artists. Art criticism studies, "rehabilitating" several artists, whose work had long been considered not worthy of attention, played a significant role in the reassessment of the past and the present.

The programmatic works of the severe style, Rafters by Nikolai Andronov and Geologists by Pavel Nikonov, demonstrate various sources. Pyotr Konchalovsky's colour effects are combined with the motifs of Alexander Deineka in Plotogons, whereas Pavel Kuznetsov's tradition with a projection on the icon-painting style of Dionisius, which in the eyes of Soviet ideologists of the early 1960s looked like absolute revolt, is actualised in Geologists. The very fact that the severe style artists turned to previously forbidden traditions was already perceived as a radical, innovative gesture by contemporaries, although certain exhaustion and "weariness" of the thematic picture was already felt in the painting of the 1960s.

In the works of Viktor Popkov, Viktor Ivanov, Dmitry Zhilinsky, Tatyana Nazarenko, it is evident that they appeal not only to their neighbours but also to distant traditions - Old Russian icon painting, the art of the early Renaissance, primitive works of the $18^{\text {th }}$ century.

It was ancient Russian art and its primary embodiment, the icon, that became a hidden, not apparent dominant and a beacon to which the masters of the severe style turned. Iconography for centuries served as the starting point of Russian art and an invisible thread connecting the masters of painting with their different styles, creative aspirations... It served as an involuntary model, a canon, sometimes intuitive, for different generations of Russian painters. The pinnacle of skill for many Soviet artists was the activity of outstanding icon painters of the past (Theophanes the Greek, Andrei Rublev, Dionisius), who embodied a new, sublime understanding of the spiritual beauty and moral strength of man in their works.

The severe style artists were attracted to Russian icons by local colours, a simplified composition and forms, a "frozen" plot... They were even more attracted by their colour saturation, joyful power or harshness of pure colours.

For example, early examples of Rublev icon painting correspond to the general rules followed by the artists of the severe style. In the Orthodox icons of the $14^{\text {th }}-15^{\text {th }}$ centuries, it was customary to depict severe and ascetic faces with characteristic Byzantine features: large eyes, a high forehead, a straight nose and thin lips. The craftsmen mainly used restrained, dark colours: dark red, brown, ochre yellow.

The icon painter and restorer of the early $20^{\text {th }}$ century, Vasily Guryanov, described the early works of Rublev as follows: "the faces are painted in thin layers, observing the sequence in the transition from illuminated to unlit places; they look greenish in the shadows and are modelled with brown ("dark") ochre without marks, that is without hits in the brightest places to indicate highlights with white paint; in accordance with the faces, the figures are also lightly modelled, and the outline is indicated only by a thin line". 
The connection with icon painting was not only in the technical aspects of painting. In the works of the severe style artist, as in the icon, emotional stress is focused on the inner life and is not expressed by external exaltation. Instead, this painting is about the amazing balance of all lines and details, about the internal balance, about the precisely adjusted centre line on masterfully painted images... In this sense, the artists of the severe style were heirs to the traditions of the Russian school of painting; they depicted severe and ascetic faces.

Obviously, the involuntary appeal to icon painting was not accidental: the artists felt the sad disappearance of the connection between generations, the tragic breakdown of age-old foundations, godlessness and... desperate longing for some other, alien Truth. All the complexity of the internal self-determination of the generation of the 1960s-1970s is seen in these voices of the era.

None of the artists was a church person, and anyway, that was impossible in Soviet times. However, there was a spiritual, "root" connection with parents who grew up in faith with artistic traditions. This Christian subtext is more likely to shine through than it is clearly pronounced, which was evident in the era of totalitarian atheism. It seems that a constant desire to "bite into life, learn, comprehend the basic laws of our being" (V. Popkov) was main here.

These were not directly religious subjects; however, in these themes, the artists touched upon something inevitably important, existing in the inner life of every person. In their main works, the artists tried to intuitively break through the border of a particular spiritual tightness of their generation, about which V. Vysotsky figuratively wrote: "And ice from below, and from above...".

Representatives of the severe style tried to reveal the theme of Light and Meaning as much as possible in the conditions of Soviet times. The truth of this search was seen in their works. They understood in a unique way, intuitively felt the invisible connection of times, the continuity of generations and traditions.

The tradition of Russian religious art was interrupted after 1917. It is interesting to note that at the same time, icons, as part of the cultural heritage, became the object of scientific research. At the same time, the atheistic policy of the state, imposing a ban on religious themes and plots, did not prevent artists who created the image of a new person in their works from resorting to formal borrowings coming from icon painting: light streaming onto the depicted model from everywhere and seemingly emanating from it (transcendental light), standing pose, front view.

Although the tradition of icon painting in the Soviet period, it would seem, was interrupted, the severe style artists were gradually looking for a way out of their creative ideas and conversation in a similar pictorial language, continuing the centuries-old traditions of icon painting, perhaps unconsciously, temporarily replacing icon painting and interpreting it in accordance with the life during Soviet times.

The severe style artists' works, related to religious issues, are a special part of their work. They became a continuation of the artists' reflections on important moral and philosophical problems, as well as an acute inner need to turn to the sources - the canons of pictorial skill, which icon painting was considered to be at all times.

Addressing this topic seems unexpected only at first glance: on the one hand, it was a way to express your protest and rejection of the existing ideology and order. On the other hand, artists were attracted by the monumental paintings of churches, the purity and clarity of the colour palette of the icon painters of the $15^{\text {th }}-16^{\text {th }}$ centuries. They also drew their inspiration from the hagiographic icons of the $17^{\text {th }}$ century, their figurative structure and their strive for allegory. Appearing in a veiled form in landscape and genre paintings, this theme was formed and manifested itself in the artists' village series and became a continuation of their reflections on significant moral and philosophical problems of the time.

Its perception and interpretation are individually embodied in the art of each master. However, at the same time, there are also common features that unite the artists, making it possible to judge how the religious theme is revealed in the work of the severe style artists. The inclusion of signs or symbols associated with religious art, which are the source of additional, "encrypted" meaning, in the composition is one of the ways or means of revealing religious issues. The work becomes ambiguous; its ideas do not lie on the surface but are hidden in the artistic weaving of the painting. "For me, as well as for many artists of my generation," noted Viktor Ivanov, "it is characteristic that the artist's 'reflections' are not shown in the finished form in the painting. They are as if taken out of the painting and the viewer sees them."

The emergence of this theme in the works of the severe style representatives stems to some extent 
from the laws of ordinary mankind: at a specific moment in life, a person begins to think about eternal, enduring values. The result of a complex inner work the achievement of a certain stage of life, a new level of self-awareness of artists, led to the fact that questions about the meaning and essence of being became a cornerstone in their work. It is symptomatic that each of them was looking for their world of sacred images far from the capital: Nikolai Andronov worked in Ferapontovo, Viktor Ivanov - in his ancestral village in the Ryazan region, Viktor Popkov travelled in the Russian North, for Pavel Nikonov the Aleksino village in the Tver region became a creative laboratory for a long time, and Pyotr Ossovsky connected his creative work with the Pskov land.

Isolation from the hustle and bustle of a modern city, solitude, immersion in oneself - this is the way of life of a hermit engaged in a spiritual search, which, among other things, led the masters to think and experience religiously.

The most substantial perception and creative transformation of icon painting in its modern form manifested itself, perhaps, in Viktor Popkov's work.

There was a deep connection with ancient Russian icon painting in the artist's work, with the images created by Dionisius and Rublev. Many famous paintings by Popkov were created under the direct influence of the Russian icon painting tradition, which can be read about in his diaries. The artist's strongest impression of Russian art was precisely from the icon, from the works of Andrei Rublev.

Popkov even made one of his first self-portraits in the icon-painting style. In 1959, the artist had a trip to Pereslavl-Zalessky to a tvorcheskaya dacha, a special country house to live and create art. A. Tutunov recalled that the first work that Viktor Popkov showed him was a self-portrait: it was painted on cardboard lined into squares, the artist himself was depicted in the centre, and the impressions of Pereslavl were on the sides, like images, kleima, around the centrepiece in the icons.

In 1964, the artist specially travelled to the ancient Ferapontov monastery to make sketches from the frescoes of Dionisius. The artist liked their smooth flowing lines, soft combinations of light, slightly whitened, tones and a calm, as if melodious rhythm. It was then that Popkov began to paint a lot in the tempera painting technique.

Popkov liked the techniques dating back to the Russian icon-painting tradition and later used them more than once in his work. Echoes of the experi- ence at Ferapontov monastery are felt, for example, in the lightened palette of the Brigade: in the image of an exceptionally high, icon-like horizon, in a calm circular rhythm that creates a feeling of unity and harmony, in a departure from spatial depth, in features that make this canvas akin to the works of D. Zhilinsky, whose work Viktor Popkov treated with special attention at that time.

Popkov, like the great masters of past centuries, was often inspired by the works of other artists. It was never a direct borrowing but always a reinterpretation, in which there was more from Popkov's own creative individuality than from the original source. Another obvious analogy is the works of Palekh masters, which in turn also go back to icon painting: it was at that time that Popkov really considered and fell in love with the refined decorative sophistication of Palekh lacquer miniatures.

Viktor Popkov, who rather quickly dealt with the problems of the severe style and went deeper in his works, which were not limited to one art movement or another, is considered a classic, the best representative of the severe style artists mainly owing to the painting Builders of the Bratsk Hydroelectric Power Station.

According to V. Barvenko, who arrived with Popkov in Bratsk, he was literally obsessed with the images of workers, drawing sketches from morning to evening. Aiming at creating a truly monumental work, he began to work even harder than usual. The idea to use a dark, night background in the artwork arose immediately, so the sketches for the painting were made at night. According to the artist himself, the idea of the painting was based on the desire "to make everyone as in icons, silhouettes on a black background". That is why monumental, "icon" figures of the workers appeared in the painting.

Another remarkable work by Popkov was done similarly - The Brigade is Resting (1965), which received recognition in Paris. Its characters do not function but stay in the space of the painting, immersed in their leisurely activities - reading, playing chess. Here, expressive techniques are even more refined than in the previous case: there is no perspective (instead, the foreground figures are placed in the lower part of the composition, and the more distant ones - in the upper part), and the mowed field on which the workers are lying is likened to a conditional planar golden background, giving this painting a similarity, not accidental, with an icon. 
At that time, a discussion of the painting The Brigade is Resting was published in one of the issues of the Tvorchestvo magazine, following the results of a professional round table: some artists spoke unkindly, many simply misunderstood this work. However, now, half a century later, it is evident that Popkov's findings were not only of artistic interest but also restored the possibility of a dialogue with the ancient Russian tradition, which seemed lost entirely until recently. Moreover, it was not a matter of borrowing individual motifs (at that time, quite modern themes prevailed in Popkov's art), but an attempt to comprehend the artistic language of icon painting - the structure of the visual field, colour patterns, etc.

A series of Mezen Widows by Popkov is permeated with special iconography. In the centre of the Widows, a tall, thin woman is depicted capturing the entire figure; her mournful face with deep wrinkles resembles an icon face or the face of an ancient wooden statue. It is turned to the viewer, but the woman restrained in emotions and full of sadness is immersed in her thoughts and memories. It seems as if the heroine of the painting has stepped down from the icon board, resurrecting in her memory the ancient icon-painting images of the holy martyrs. This is the most striking figure of all, austere and majestic; like a column, she holds the whole painting on her. Intuitively, almost guessing, Popkov approached the theme of Christian humble acceptance and bearing of the cross.

In Popkov's still life with a grey patchwork quilt, the appearance of an icon is noteworthy. On the one hand, it seemingly symbolises a connection with traditions, and on the other, it is painted unexpectedly unusually. Looking at it, you realise that you cannot recognize the plot depicted, that iconography of this kind does not exist and that it is obviously entirely invented by the artist, perhaps as a hint of the need for an eternal search in art.

In Popkov's painting Mother and Son, the artist painted himself sick, lying in bed under a large blanket, and portrayed his mother standing nearby and reading the Bible. The work is filled with warmth and comfort that the artist felt when he came to his mother. Stepanida was very devout; she worked for many years as a bell ringer in a church - it is with a prayer that she heals her son, running her finger along the lines in the Bible and addressing both her son and the icon of the Mother of God in the red corner. Viktor was never a devoutly religious per- son; however, he always treated believers with respect. The motif of motherhood is present in the painting in two ways - in the images of the mother and son and in the icon of the Mother of God with Jesus Christ. It is in common with the eternal theme of the Mother of God and the Child - the theme of sacrificial motherly love and prayer for her son, who is destined to carry his cross.

Surprisingly, it was in Germany that he conceived the idea of the painting In the Cathedral, depicting the interior decoration of a Russian church as if a short stay abroad stirred up nostalgia for something native, Russian. ...We see tourists raising their heads to the frescoes: elongated, almost ethereal (not in detail) figures of people look like frescoes practically erased by time and look less real than the shadows of images preserved on the walls of the cathedral - an exact metaphor for the ephemerality of human existence, momentary and transient, in contrast to the centuries-old frescoes. For this painting, Popkov made many pencils and pictorial sketches from Old Russian murals.

The painting I am 40 Years Old (1972), painted probably under the influence of Russian icon painting tradition, stands apart in the master's work. Looking at the image created by the artist, one can feel that the fortieth anniversary became an important milestone for the artist, an occasion to comprehend his own life and what he managed to do by that time. An angel is in the centre of the painting. It is a disembodied, almost entirely transparent creature with enormous open wings, holding the artist's head in his hands, while the latter's body is lying decapitated at his feet. Headless, with broken hand gestures, it looks completely defenceless; however, the angel's wing is spread over it like protective armour.

In another biographical painting by Popkov, My Day (1968), one can see how the coordinate system completely collapses, and three images appear in inking, like fresco images, acquiring a symbolic meaning.

The painting Northern Chapel (1973) is another example of a painting on a religious theme in Viktor Popkov's work. The main character here is a little boy who is also the viewer. Placing the boy's figure in front of an open door in the sacred space of the chapel, the artist thereby focuses attention on "the adolescent's entry into the church, communion with the spiritual".

In the initial sketch of the painting Northern Chap$e l$, the boy (we see only his head) is standing in the 
centre of the church next to the iconostasis, under the dome, painted with colourful frescoes and occupying most of the composition. A jubilant mood prevails: the iconostasis is festive with colours; the sky-blue with red details of saint figures dome, divided into sectors, seems to be radiant and resembles the sun. The artist chose such a perspective that the viewer feels like looking at the dome with his head thrown back, feeling slight dizziness and understanding what is happening in the boy's soul. In the final version, there are figures depicted above the entrance to the chapel. The composition is designed in such a way that guardian angels, having flown to the entrance to bless the boy and everyone entering, are seen in these figures. The chapel's space is perceived as the house of God ascended above the earth, the beauty of which the boy marvels, and the doorway seems to be a window from heaven to earth.

Another painting by Popkov, Grandma Anisya was a Good Person, became iconic in this topic. To enhance the planar effect, more vividly presenting the main group of characters, the final version of the picture was painted not with oil paints but with tempera. However, the focus on the essentials did not, of course, underestimate the details. According to the artist, it was the opportunity to examine the details that was supposed to make the space of the painting closer, even dear to the viewer, and also provide the key to understanding the general concept of the work. The artist's notes contain the following inscription: "To paint Grandma Anisya as a coloured engraving and an icon... Faces as in icons ochre, moulding, highlights." Indeed, this icon style can be felt when looking at the painting: the characters, side by side in tears, resemble figures from icons, the silhouette of the figure in a light raincoat depicted from the back is like the silhouette of an angel, and in general, the motif of mourning, a farewell is like in icon painting. The Dormition of the Mother of God is involuntarily recalled as a possible prototype. It is a fundamentally different language - the language of metaphysical concepts, which is timeless for any century.

It is interesting that, referring to the problem of the spiritual origins of art in the 1960s, A. Morozov emphasised the inner artistic relationship of Korin and Popkov: "It is curious to note that Popkov's formation took place not without the indirect influence of P. Korin. The middle of the 60 s is the peak of the old master's popularity, associated with the release of his cycle Rus to the public. The heroines of the painting Memories. Widows (1966-1968), the first masterpiece of mature Popkov, involuntarily echoed Korin's characters. They were perceived as a powerful historical and national type, which had no other analogy in our painting." In the artist's archive, a photograph was found. It captured Viktor Popkov among those present at the funeral service for Korin in the Assumption Cathedral of the Novodevichy Convent. This emphasises the inseparability of spiritual and artistic traditions, despite all the efforts of the Soviet authorities to wipe out the legacy of the past and build socialist realism from scratch.

Nikolai Andronov's works, in which the artist indirectly used biblical motifs and Christian iconography, are examples of the appeal of the severe style artists to religious issues. By building the subtlest associations, complex hints, using iconographic principles, he created a kind of interweaving, a connection between the Gospel stories and the life of an ordinary village. Andronov's metaphorical meaning does not always lie on the surface; however, on the other hand, it is obvious to the aware viewer. For example, in the painting Likbez (1972), teaching to read and write the villagers is perceived as the New Testament scene The Last Supper widespread in religious art, and in the painting Family (1976) - the gospel story Christmas.

In Likbez, such an allusion is indicated by the number of participants, fine-looking, as if copied from icons, the appearance of peasants, imitation of azure highlights on their clothes, the characteristic plasticity of the characters. It is also worth paying attention to the space between the two central figures sitting with their backs to the viewer in the foreground: their outline resembles a goblet - a motif common in icon painting and serving as a reminder of the Eucharistic bowl. Also, a detail such as the image of a dog in the lower right corner appears. In the compositions of The Last Supper, the dog is often placed next to Judas, who is always isolated from the disciples using various pictorial techniques, for example, the colour of his clothes. In those cases, when all the disciples are depicted with halos, his halo could be painted in black or be completely absent... All this can be attributed to the figure in Andronov's painting, sitting with his back to the dog; compared to other heroes, the artist highlighted the scarf with dark colour. Thus, through comparison with one of the divine sacraments, teaching peasants to read and write is perceived as a process 
of their introduction to the world of spiritual culture. The artist conveyed the state of comprehension of the secret, the transformation of ignorant peasants into initiated ones.

In the painting Family, the artist is attentive to every detail of the painting and deduces from a seemingly everyday motif the image of a biblical event. Thus, village life takes on a special meaning. The male character can be perceived as Joseph the carpenter and as a simple peasant, and the female image as Mary or as a peasant woman. Two sources of light can also be seen: the open door and the mystical light from the nursery. The emergence of a surreal source can be associated with the traditional iconography of the Christmas plot.

In Andronov's village series, a window acts as a connecting link between the human world and the natural world, connecting the world of everyday life with the spiritual world. On the other hand, the window frame becomes a kind of border between man and immense nature. In this sense, Andronov's series of windows becomes a symbol of that secluded, contemplative life filled with inner work that the artist had in Ferapontovo.

Nikolai Andronov has self-portraits against the background of icons. Their paradox lies in the fact that it is difficult to name another work in our art, where a person of the generation of the 1960s is so clearly recognised. In Self-Portrait in a Museum, the hero in his cross-patterned sweater, as on the robes of a saint, belongs in spirit to the same soil that created the ancient iconic image.

The figurative world of Nikolai Andronov's painting appeared, as a rule, in substantial and concentrated forms. With the naked eye, it is possible to notice the plastic, spatial-compositional and spiritual bonds that permeate this wholeness, accumulated by the master's creative and life experience. The master's comprehension of the landscape of the $19^{\text {th }}$ century, the heritage of the Russian avant-garde of the early $20^{\text {th }}$ century, painting of the 1920 s was combined with a deep interest in frescoes (Dionisius).

The artist was alien to underestimating our spiritual tradition, including church tradition, and folklore, and ancient architectural monuments - the churches that he painted so often and earnestly, and the memory of his beloved Dionisius, and the icons that he closely examined both in a museum and in a village hut. For Andronov, all this is not just a grain of memory but, to a great extent, the work of the soul and a test of living human conscience.
Like the painting of other severe style representatives, Geliy Korzhev's painting is largely cleared of minor details, and his characters do not belong to this century. Korzhev's environment is conditional to the same extent as the landscape of an icon. And the generalised human figure from hundreds of his paintings is a portrait of the people, through which the era is refracted in his painting.

Traces of War is the central, most famous painting in the artist's work. A portrait of a soldier looking directly at the viewer with a single piercing blue eye, with an innocent face covered with thin burnt skin. A disabled, dirty man, burned by fire and sun. If one closes one part of the face, a dead man with a pointed nose will be seen; the other part portrays a living, strong person. It is almost an icon - a fullface, no emotion, no background - the reality in which it is located is not specified. Traces of War is like a negative of Dürer's painting. The same monochrome background, only dark. The human face is iconographic and beautiful.

Korzhev outlived the country where he was recognised, took its collapse hard; however, he also changed himself, leaving the previously important and relevant topics and mastering new ones. It is interesting that, not being a churched person, after the death of his parents, he turned to biblical stories. And this only helped him in his work. Nevertheless, the artist hardly changed the techniques developed in his youth. In the 1964 painting, the mother is painted in much the same way as the mother in Carrying the Cross from the 1999 biblical series.

The artist worked on this series for a quarter of a century - from the mid-1980s to the end of his life. Starting to develop the biblical series, or even a little earlier, Korzhev moved away from active social activities and became almost a hermit. The master's address to the biblical topic was a continuation of his reflections on the main spiritual, moral and philosophical problems and was realised with remarkable directness. In the interpretation of the plots of the Old and New Testaments, the construction of the internal logic of the narrative, proceeding from ethical and moral concepts that determine the actions of a person, was the main point for Korzhev, an artist-thinker, wise with a rich life experience.

Religious and philosophical issues also appear in the village series by Pavel Nikonov. One of its ideas was to embody the plots of Scripture in daily sketches, which, through iconographic associations 
with biblical scenes, lose their straightforward interpretation and acquire additional meaning. Nikonov generalised the figures to the state of signs and brought the landscape to the state of conditional icon-painting hills. This transfer of evangelical events to a specific dimension was not something unique: according to Nikonov, when he conceived a series of paintings on a biblical theme, he recalled the work of the Dutch master, Pieter Bruegel, the Elder.

Pyotr Ossovsky found his spiritual homeland on the land of the ancient Pskov region with its pristine beauty and harsh epic grandeur, amazing nature and courageous people, which is reflected in many of his thematic paintings, close to iconic images. In the portrait images: Ascetic, Pskovite Woman, Huntsman Mikhail, Vasilisa, Siberian Old-timer, Mother and Father, he noticed features that testify to the moral purity of the Russian person, the integrity of the personality, about serving his land and faith in your destiny. The series of self-portraits that the master painted throughout his life is of particular importance. The latest of them is Self-portrait. White Square of the Canvas, in which the artist portrayed serious reflections on the fate of a creative person in society, their role and significance.

The land of ancient Pskov, which Ossovsky called his spiritual homeland, became a source of images for the artist that reflected not only the national identity of the Russian province of the middle of the last century, its unique patriarchal atmosphere and originality but which also turned out to be astral - outside of time and certain space.

The heroes of Viktor Ivanov's works are ascetic and austere; the paintings are monumental. The influence of icon painting, which many artists of the severe style were fond of, same as the avantgardists before (it was not in vain that Ivanov studied in the workshop of Alexander Osmerkin, a Jack of Diamonds artist), is evident in them.

One of Ivanov's best paintings is Family. 1945 (1957-1964), which tells about the first days of a peaceful life after the victory over fascism. His canvas is a typical example of the severe style, depicting a solemn peasant meal, where deep tenderness and joy of the newly acquired integrity are hidden behind the external restraint of emotions.

He remained faithful to the peasant theme in his latest works and is just as indifferent to the time frame. His Mowers (1991) in white shirts could have been painted in the 1970s, and the peasant women with icon-painting faces in the Ryazan Fields (2005) cleaning the haystacks seem to be frozen in eternity.
Ivanov's landscapes represent a mysterious and boundless world; nature in them becomes a prayer image. An image of a church on a high bank in the background is one of the frequently recurring motifs of his panoramic landscapes. This elevation, as the foundation for the church, is as if a solid foundation of faith.

There is an internal, spiritual connection between Viktor Ivanov's paintings. In them, he reflected the stability, value of life phenomena. Hence the composition, the power of colour, the fullness of the entire form. The artist's works are dedicated to the people of the modern village; however, he was not a painter of everyday life. Village life, the work of people - this is a theme permeated with a single concept, through which Ivanov brought his views on the world to the viewer, expressed the ideas of the time, asserted his ideals.

Many critics rank Dmitry Zhilinsky among the artists of the severe style. However, the artist himself believed that he "only lived at the same time as them". Nevertheless, the artist had much in common with his colleagues in the movement. In his work, Zhilinsky turned to the legacy of Old Russian icon painting and the Italian and Northern Renaissance. Every phenomenon, hero or object in his paintings hides a whole story, full of metaphorical assimilations, symbols and allegories. The works of this master are characterised by saturation with symbols; there are no random details in his paintings.

The image of his mother, Anastasia Fedorovna, is one of the most heartfelt images in Zhilinsky's work. It is most vividly presented in the painting Under an Old Apple Tree (1969), dedicated to the tragic history of the artist's family. As a basis, Zhilinsky used a board, preparing it like for an icon. In the ark - a deepened centre field on the front side of the board, he depicted his mother and children, and in the margins, he placed the figures of his father, who was shot in 1937, and his brother, who died during the war in $1944 \ldots$ The comparison of a fruit-bearing tree and a woman surrounded by grandchildren becomes a metaphor for an indestructible vitality. In its wide flat frame painted with white paint, with two images placed on it, the painting evokes ancient Russian icons with images in the margins. The technique in which the work was done (with tempera paints on gesso) also comes from Old Russian icon painting.

The etching The Sistine Madonna by Vladimir Daichman, made in the spirit of the severe style, is extremely expressive. The vertical format of the sheet 
emphasises the narrow space of the bunker, where the canvases are stored in barbaric neglect. Dusty stairs lead up. A Red Army soldier with a submachine gun is standing there, in the opening of the door. Rays of sunlight highlight the face of the Madonna and child out of the darkness. The dynamism of the scene is given by the reversal of the soldier's figure, the contrast between the bright light pouring from the outside and the darkness of the room, the special character of the stroke. This painting is a symbol of the constant struggle of Soviet barbarism and rejection of traditions against the eternal beauty of iconic images and great paintings that have become iconographic.

Unfortunately, the severe style, that arose in spite of the endless images of jubilation of Soviet holidays and ceremonial portraits of leaders, had its weaknesses. Over time, many of its adherents became hostages of their own artistic program: the search for laconic simplicity often led to a certain emasculation and schematisation of images, and the desire for monumentality sometimes turned into indifference to details and exaggeration of the depicted. Paradoxically, over time, the masters of this style, who initially set themselves the goal of reflecting the truth of life, increasingly began to create a kind of work mythology in their works, in fact, falling into the same myth-making that they once fought against. The newfound novelty, a fresh outlook on life degenerated into a cliché over time.

However, the best works of this movement, in which the connection with icon painting is especially clearly traced, are remarkable examples of creative freedom. In them, the artists did not look back at the ideological guidelines; for many of them the Russian icon with its pure colours, laconicism, truth was a creative beacon. It was these features that the representatives of the severe style endowed the paintings that became a phenomenon of the Soviet era in the 1960s-1970s and made their way to the viewer, like the light of an icon breaks through the walls to a believer.

The images in these works are not individualised but rather generalised. Nevertheless, this does not interfere in any way with understanding the state of mind of the characters; maybe, on the contrary, it makes it more pure, detached from concrete signs of reality, and therefore deeper. In these painting, artists' desire to display the inconceivable naturally becomes akin to the tasks that Russian icon painters have faced for centuries.

Through metaphorical pictorial language, artists of the severe style returned the original traditions of Russian life, in which the icon was always the central axis and the basis that binds the foundations of spiritual life, to the Soviet people, torn from their roots.

However, the similarity with the icon was not only in pictorial, spiritual and philosophical senses but also manifested itself in the social role of large paintings of the severe style painters, which became a good examplel. Monumentality, posterity, large format, laconicism and expression - all this gave the paintings an acutely relevant and, at the same time, epic, highly civic meaning. The paintings undoubtedly greatly influenced the cinema and painting of the following decades, raising new questions of a moral and ethical sense.

Being Russian by birth, the severe style artists, perhaps without knowing it, reached the level of great national artistic generalisations, made by them on the basis of purely Russian material, based on their own experience and knowledge of their people's lives.

The severe style is a phenomenon that was so categorically assigned the status of something episodic, even fleeting, turned out to be, in different versions, compatible with philosophical and religious postulates that are relevant at all times, with a national idea and an attraction to eternity.

\section{REFERENCES}

1. Alekseeva, T. P. 2017. "Images of the People and the Fate of Individuality in the Severe Style Painting", Cultural Heritage of Siberia, vol. 3, no. 21, pp. 40-45.

2. The Bible Through the Eyes of a Socialist Realist. Geliy Korzhev. Exhibition catalogue, December 12, 2012 May 27, 2013, Moscow.

3. Bobrikov, A. A. 2003. "The Severe Style: Mobilisation and Cultural Revolution", Art magazine, no. 51-52, pp. 29-33.
4. Bondarenko, L. K. 2005. The Theme of the Village in the Works of Soviet Painters of the 1960s-1970s, Thesis of the Candidate of Art History: 17.00.04 [Place of thesis defence: Moscow Surikov State Academic Art Institute]. Moscow

5. Burganova, M. A. 2008. "The Severe Style: Direct Speech", Art Literature Scientific and Analytic Journal Burganov House. The Space of Cultur, no. 1, pp. 8-33. 
6. Butkevich, D. 2006. "With a focus on the Severe Style", Nezavisimaya Gazeta. January 27, p. 3.

7. Dekhtyar, A. A. 1981. Pavel Nikonov. Leningrad: Artist of the RSFSR, p. 69

8. Zaitsev, E. V. 2000. Geliy Mikhailovich Korzhev: On the Occasion of his 75 ${ }^{\text {th }}$ Birthday, Moscow, p. 111.

9. Victor Popkov [Text] / [text: P. Kozorezenko; photo: V. Kubarev]. Moscow, 2012. P. 457, [6]: illustration.

10. Voloshina, I. 2015. Victor Popkov: An Artist on the Widow's Land. Foma, no. 12. pp. 62-71.
11. "Time of Change: Art of 1960-1985 in the Soviet Union." [Catalogue] State Russian Museum. St. Petersburg: Palace Editions, 2006. P. 415: illustration.

12. Matthew Cullerne Bown. 1991. Art under Stalin. Oxford, Phaidon Press.

13. Realismi Socialisti. Grande Pittura Sovietica 1920-1970. Milano, Skira, 2011. 


\section{ОБРАЗ ИКОНЫ В ТВОРЧЕСТВЕ ХУДОЖНИКОВ «СУРОВОГО СТИЛЯ»}

\begin{abstract}
Аннотация. Важным импульсом творчества мастеров «сурового стиля» стало обращение к художественным традициям разных эпох - их своеобразное восприятие приёмов постимпрессионизма, наследия русского авангарда, искания советских живописцев 1920-1930-х годов, а также искусство Проторенессанса и Древней Руси. При художественных экспериментах и активном обращении к разным изобразительным линиям они умело соединяли в своих произведениях опыт древнерусского искусства, накладывая традиции иконы и фрески, живопись примитивизма на современные лекала.

Скрытой, не явной доминантой творчества мастеров «сурового стиля» стало древнерусское искусство и его главное воплощение - икона. Вершиной мастерства для представителей этого направления была деятельность выдающихся иконописцев прошлого (Феофана Грека, Андрея Рублёва, Дионисия), которые в своих произведениях воплотили новое, возвышенное понимание духовной красоты и нравственной силы человека.

Художников «сурового стиля» привлекали в русской иконе локальные цвета, упрощённая композиция и формы, «застывший» сюжет. Ещё более влекла их цветовая насыщенность, радостная сила или суровая мощь чистых красок. Однако связь с иконописным
\end{abstract}

Кардинальные метаморфозы духовной и нравственной жизни народа в годы Великой Отечественной войны положили начало новому этапу в художественной практике мастеров искусства, обострили их восприимчивость к скрытым элементам и веяниям действительности.

Поиски привели к утверждению нового героя - современника-созидателя, внутренне собранного, демонстрирующего твёрдость нравственных принципов, готового к труду и борьбе. Самоценность живого человека, очищенного от искусством - не только в технических аспектах живописи. В произведениях художников «сурового стиля» также, как в иконе, эмоциональное напряжение сосредоточено на внутренней жизни, а не выражается внешней экзальтацией.

Обращение к иконописи не было случайным: художники ощущали печальный распад связи поколений, трагический слом вековых устоев, богооставленность и... отчаянную тоску по какой-то другой, нездешней Правде. В этих голосах эпохи - вся сложность внутреннего самоопределения поколения 1960-1970-х. Представители «сурового стиля» старались раскрыть тему Света и Смысла, насколько это было возможно в условиях советского времени. Правда этого поиска выплеснулась на их холсты.

«Суровый стиль» — явление, которому так безапелляционно присваивали статус чего-то эпизодического, даже мимолётного, оказалось в разных вариантах совместимым с актуальными во все времена философскими и религиозными постулатами, национальной идеей, влечением к вечности.

Ключевые слова: суровый стиль, русская икона, религиозный сюжет, аскетичные лики, нравственная сила, правда жизни, Попков, Никонов, Коржев.

идеологической шелухи, привела художников к разработке темы человека и его места в современном мире. Молодым мастерам хотелось показать героя трудовых будней крупным планом в типических обстоятельствах своего времени.

В живописи новый специфический способ раскрытия внутреннего мира героя обозначался в сокрытии духовной энергии и потенциала в лаконичной форме, суть передавалась посредством поиска взаимосвязи между внешним обликом и внутренним состоянием человека, появилась 
новая трактовка пространства и времени, сами произведения стали отличаться широтой идейных обобщений. Общая цель, сплотившая большую группу художников, породила общность эстетических принципов и формальных приёмов и позже была условно названа «суровым стилем».

Живописцы ощущали изношенность «старых» технических средств и композиционных систем, отрицая пассивность «парадных» произведений искусства, поэтому они обратились к поиску новых художественных приёмов, которые смогли бы пробудить интерес и вовлечь зрителя в увлекательный процесс поиска духа времени и утверждения обновлённого человека, стремясь подтолкнуть к сопереживанию содержания своих работ. В работах будущих «суровостильцев» - П.П. Оссовского «У переезда», Г.М.Коржева «В дни войны» и В.Ф. Стожарова «За дровами», представленных на первой молодёжной выставке, искусствоведы и зрители почувствовали смену интонационного строя в восприятии окружающей действительности - сдержанность, сосредоточенность, лаконичность, достоверность.

Ведущими качествами поколения являлись уникальный жизненный опыт, нетерпимость ко лжи, созидательное начало, осмысленный подход к творчеству, твёрдая гражданская позиция и бесстрашие. Художники не разрывали связь с предыдущим наследием, а вычленяя всё самое ценное, идеологически незамаранное, складывали из этих составляющих новое искусство, давая свою нравственную оценку современности и недавней истории. Они хотели сказать своё слово и быть услышанными, поэтому каждый боролся за собственное творчество до конца.

В попытке уловить нерв времени «суровостильцы» отправлялись «документировать» действительность в самые природно-недружелюбные уголки страны. Поиск настоящего человека, трудящегося в тяжёлых условиях, проводящего каждый день в борьбе со стихией, стал диктовать свой новый изобразительный язык: пренебрежение красотой натуры, некоторая условность и графичность её изображения, сдержанный колорит, монументально-плакатные лаконичные формы, особый типаж героев и внутреннее эмоциональное насыщение полотен (энергичность, сдержанность, дерзость, преодоление, драматизм), эпическое звучание представленных художником сцен.

Художники сурового стиля стремились противопоставить своё творчество официозному па- фосу плаката и официально-имперской стороне социалистического реализма. Уже в контексте их раннего творчества постепенно вырабатывались такие параметры «сурового стиля», как изображение неприукрашенной реальности, отход от подробного литературного повествования, стремление к психологической трактовке образов, метафоричность художественного языка, расширяющая смысловые границы произведения.

Эта обезоруживающая беспафосность действовала сильнее, чем надоевшие клише изображения «творческого человека», более того - в ней была своя негромкая жизненная подлинность, ведь существование художника состоит из таких рядовых ситуаций, вполне будничных, но при этом наполненных сокровенной внутренней жизнью, чудесным образом разрешающейся произведениями искусства.

В центре внимания «суровых» - тема рабочих будней, поэтизация повседневного труда человека. Самое прозаическое и обыденное становится предметом монументализации и гордого возвеличивания. Их персонажи - люди брутальных профессий - строители, геологи, ремонтники, плотогоны, полярники. Они одновременно имеют и индивидуальные портретные черты, и формируют собирательный образ мужественного героя. Всё в этих персонажах говорит об их непростой жизни, упорстве, духовной и физической мощи.

Новый стиль демонстрирует протестантский тип героя - взрослого и ответственного, обладающего собственным опытом, личной верой и вообще развитой внутренней мотивацией (и потому не нуждающегося во внешнем идеологическом стимулировании со стороны партии), хотя и действующего в рамках общего преобразовательного проекта. Художники смогли на время оглядеться, понять время и самих себя, убежать от оскорбительной фальши советских идейно-воспитательных ритуалов, от столичных витрин коммунистического процветания во внутренний мир простого человека.

«Суровые» в большей степени поглощены отображением внутренней, духовной работы персонажей, чем описанием окружающей их действительности. Больше всего в трактовке внешнего облика героев художники уделяют внимание лицам и рукам персонажей, так как именно они и их взаимодействие проявляют внутреннее состояние человека. Хотя порой в полотнах «сурового стиля» представали не лица отдельных людей, а одухотворённый лик целого поколения. 
В соответствии со своим миропониманием и общим впечатлением эмоциональной напряжённости «суровые» избирали и художественные средства. Художники П. Никонов, В. Попков, Г. Коржев, братья А. и П. Смолины, П. Оссовский и другие в поисках «правды жизни» обратились к сдержанной, условной, обобщённой форме, отвергнув всякую описательность. Зачастую художники работают большими плоскостями, используют жёсткие пластические формулы, укрупняют и уплощают изображение. Произведениям присущи такие художественные особенности, как лаконизм, ритмичная, но уравновешенная и монументаризированная, преимущественно фронтально развернутая композиция с острыми линейными ритмами, чёткая очерченность контуров, конструктивная лепка формы, экспрессивность, колористическая сдержанность с лапидарными цветовыми пятнами. Колорит, как и вся атмосфера их полотен, подчёркивает суровость темы и образов героев, акцентирует аскетизм и духовную насыщенность, глубину. В картинах преобладают оттенки чёрных, коричневых, землистых цветов и другие минорные тона. Крупные планы, провоцирующие вглядывание в героев. Эти картины очень близки изобразительным традициям древнерусской иконы и ранних русских «персонных» портретов XVII в.

Важным импульсом творчества мастеров «сурового стиля» стало обращение к художественным традициям разных эпох - их своеобразное восприятие приёмов постимпрессионизма, наследия русского авангарда, искания советских живописцев 1920-1930-х годов, а также искусство Проторенессанса и Древней Руси. При художественных экспериментах и активном обращении к разным изобразительным линиям они умело соединяли в своих произведениях опыт древнерусского искусства, накладывая традиции иконы и фрески, живопись примитивизма на современные лекала.

Художники вдохновлялись их шедеврами прошлых столетий и как будто находились в постоянном внутреннем диалоге с мастерами, чьё наследие столетиями являлось источником плодотворных идей в русской живописной культуре и не могло быть уничтоженным за несколько десятилетий.

Изучение творчества мастеров прошлого значительно расширило стилистически и тематически границы творчества советских художников.
Немалую роль в переоценке прошлого и настоящего сыграли искусствоведческие исследования, «реабилитировавшие» целый ряд мастеров, творчество которых долго считалось не заслуживающим внимания.

Программные произведения «сурового стиля» - «Плотогоны» Николая Андронова и «Геологи» Павла Никонова - демонстрируют разнообразие источников. И если в «Плотогонах» цветовые эффекты Петра Кончаловского сочетаются с мотивами Александра Дейнеки, то в «Геологах» актуализируется традиция Павла Кузнецова с проекцией на иконописную стилистику Дионисия, что в глазах советских идеологов начала 1960-х годов выглядело абсолютной крамолой. Сам факт обращения «суровых» к запрещённым ранее традициям уже воспринимался современниками как радикальный новаторский жест, хотя в живописи 1960-х годов уже чувствуется определённая исчерпанность и «усталость» тематической картины.

В работах Виктора Попкова, Виктора Иванова, Дмитрия Жилинского, Татьяны Назаренко очевидно обращение не только к ближним, но и к дальним традициям - древнерусской иконописи, искусству раннего Ренессанса, примитивам XVIII века.

Скрытой, не явной доминантой и маяком, к которому обращались мастера «сурового стиля», стало именно древнерусское искусство и его главное воплощение - икона. Иконопись веками служила отправной точкой русского искусства и незримой нитью, связывающей мастеров живописи с их разными стилями, творческими устремлениями... Она служила невольным образцом, каноном, порой интуитивным, для разных поколений русских мастеров кисти. Вершиной мастерства для многих советских художников была деятельность выдающихся иконописцев прошлого (Феофана Грека, Андрея Рублёва, Дионисия), которые в своих произведениях воплотили новое, возвышенное понимание духовной красоты и нравственной силы человека.

Художников «сурового стиля» привлекали в русской иконе локальные цвета, упрощенная композиция и формы, «застывший» сюжет... Ещё более влекла их цветовая насыщенность, радостная сила или суровая мощь чистых красок.

Например, ранние образцы рублевской иконописи соответствуют общим правилам, которых придерживались мастера «сурового стиля». 
На православных образах XIV-XV веков принято было изображать суровые и аскетичные лики с характерными византийскими чертами: большими глазами, высоким лбом, прямым носом и тонкими губами. Мастера использовали в основном сдержанные, тёмные цвета: тёмно-красный, коричневый, охристо-жёлтый.

Ранние работы Рублёва иконописец и реставратор начала XX века Василий Гурьянов описывал так: «..лики написаны тонкослойно с соблюдением крайней последовательности в переходе от освещённых мест к неосвещённым, выглядят определённо зеленоватыми в тенях и моделированы коричневой («тёмной») охрой без отметок, т.е. без ударов на наиболее светлых местах для обозначения белою краскою бликов; в соответствии с ликами так же слабо моделированы и фигуры, а контур обозначен лишь тонкой описью».

Связь с иконописным искусством была не только в технических аспектах живописи. В произведениях художников «сурового стиля» также, как в иконе, эмоциональное напряжение сосредоточено на внутренней жизни, а не выражается внешней экзальтацией. Эта живопись, скорее, об удивительной взвешенности всех линий и деталей, о внутреннем балансе, о точно выверенной линии центра на мастерски написанных образах... В этом смысле художники «сурового стиля» были наследниками традиций русской живописной школы изображать суровые и аскетичные лики.

Очевидно, что невольное обращение к иконописи не было случайным: художники ощущали печальный распад связи поколений, трагический слом вековых устоев, Богооставленность и... отчаянную тоску по какой-то другой, нездешней Правде. В этих голосах эпохи - вся сложность внутреннего самоопределения поколения 1960-1970-х.

Никто из художников не был церковным человеком, да и это было невозможным в советское время. Однако существовала духовная, «корневая» связь с родителями, выросшими в вере, с художественными традициями. Этот христианский подтекст, скорее, просвечивает, нежели явственно проговаривается, что было очевидно в эпоху тоталитарного атеизма. Думается, что главным здесь было собственное постоянное стремление «вгрызаться в жизнь, узнавать, постигать основные законы нашего бытия» (В. Попков).

Это не были напрямую религиозные сюжеты, но в этих темах художники затрагивали что-то неизбежно важное, «сущее» во внутренней жиз- ни каждого человека. В своих главных работах художники пытались интуитивно пробить границу некой духовной тесноты своего поколения, о которой образно написал В. Высоцкий: «И снизу лёд, и сверху...»

Представители «сурового стиля» старались раскрыть тему Света и Смысла, насколько это было возможно в условиях советского времени. Правда этого поиска выплеснулась на их холсты. Они по-особому понимали, интуитивно ощущали незримую связь времён, преемственность поколений и традиций.

Традиция религиозного русского искусства была прервана после 1917 года. Интересно отметить, что иконы при этом, как часть культурного наследия, стали объектом научных исследований. В то же время, атеистическая политика государства, накладывая запрет на религиозную тематику и сюжеты, не мешала художникам, создававшим в своих работах образ нового человека, прибегать к формальным заимствованиям, идущим от иконописи: свет, струящийся на изображаемую модель отовсюду и будто исходящий из неё (трансцендентный свет), поза предстояния, вид анфас.

Хотя традиция иконописи в советский период, казалось бы, прервалась, художники «сурового стиля» исподволь искали выхода своим творческим замыслам и разговора похожим живописным языком, продолжая многовековые традиции иконописания, возможно, неосознанно, на время заменяя иконописное искусство и интерпретируя его в соответствии с жизнью советского времени.

Произведения мастеров «сурового стиля», связанные с религиозной проблематикой, составляют особую страницу их творчества. Они стали продолжением размышлений художников о важных нравственных и философских проблемах, а также острой внутренней потребностью обратиться к истокам - канонам живописного мастерства, коими во все времена считалась иконопись.

Обращение к этой теме кажется неожиданным лишь на первый взгляд: с одной стороны, это был способ выразить свой протест и неприятие существующей идеологии и порядков. С другой стороны, художников привлекали монументальные росписи храмов, чистота и ясность цветовой палитры иконописцев XV-XVI веков, своё вдохновение они черпали и в житийных иконах XVII века, их образном строе и стремлении к иносказанию. Появившаяся в завуалированной форме в пейзажных и жанровых полотнах, эта тема сформировалась и проявилась 
в «деревенских сериях» мастеров и стала продолжением их размышлений о важных нравственных и философских проблемах времени.

Её восприятие и интерпретация получают индивидуальное художественное воплощение в творчестве каждого мастера. Но в то же время, обнаруживаются и черты общие, объединяющие художников, которые позволяют в целом судить о том, как решается религиозная тема в творчестве «суровых». Одним из путей или способов раскрытия религиозной проблематики становится включение в композицию ассоциирующихся с религиозным искусством знаков или символов, которые и являются источником дополнительного, «зашифрованного» смысла. Произведение становится многозначным, его идеи не лежат на поверхности, а скрыты в художественном плетении полотна. "Для меня, как и для многих художников моего поколения, - отмечал Виктор Иванов, характерно, что сами «размышления» художника в готовом виде в картине не показаны. Они как бы вынесены за пределы полотна и должны возникнуть у зрителя».

Появление данной темы в творчестве представителей «сурового стиля» проистекает в какой-то мере из закономерностей общечеловеческих: в определённый момент жизни человек начинает задумываться о ценностях вечных, непреходящих. Результат сложной внутренней работы - достижение определённого жизненного этапа, нового уровня самосознания художников - привёл к тому, что вопросы о смысле и сущности бытия стали краеугольными в их творчестве. Симптоматично, что каждый из них искал свой мир сакральных образов вдали от столицы: Николай Андронов работает в Ферапонтово, Виктор Иванов - в своем родовом селе в Рязанской области, Виктор Попков путешествует по Русскому Северу, для Павла Никонова творческой лабораторией на долгое время становится деревня Алексино Тверской области, а Пётр Оссовский связал своё творчество с псковской землей.

Изоляция от суеты современного города, уединение, погружение в себя - в этом видится образ жизни отшельника, занятого духовным поиском, который, среди прочего, наводил мастеров на размышления и переживания религиозной направленности.

Самое сильное восприятие и творческое перерождение иконописи в современной форме проявилось, пожалуй, у Виктора Попкова.
В творчестве художника существовала глубинная связь с древнерусской иконописью, с образами, созданными Дионисием и А. Рублёвым. Многие известные картины Попкова создавались под прямым воздействием русской иконы, о чём можно прочитать в его дневниках. Самое сильное впечатление художника от русского искусства - было именно от иконы, а среди икон от произведений Андрея Рублёва.

Даже один из первых автопортретов Попков построил в иконописном стиле. В 1959 году у художника случилась поездка в ПереславльЗалесский на творческую дачу. А. Тутунов вспоминал, что первой работой, которую ему показал Виктор Ефимович, был автопортрет: на картоне, разлинованном на квадраты, в центре был изображен сам автор, а по бокам, как клейма вокруг средника в иконах, - впечатления от Переславля.

В 1964 году художник специально ездил в древний монастырь Ферапонтово, чтобы сделать этюдные зарисовки с фресок Дионисия. Художнику нравились их плавные струящиеся линии, мягкие сочетания светлых, чуть разбеленных, тонов и спокойный, словно напевный ритм. Именно тогда Попков начал много писать в технике темперной живописи.

Приёмы, восходящие к русской иконописной традиции, полюбились Попкову и позднее не раз использовались им в работе. Отголоски ферапонтовского опыта чувствуются, например, в высветленной палитре «Бригады», в изображении исключительно высокого - иконного - горизонта, в спокойном кругообразном ритме, создающем ощущение единства и согласия, в уходе от пространственной глубины, в чертах, которые роднят это полотно с работами Д. Жилинского, к творчеству которого Виктор Ефимович в то время относился с особым вниманием.

Попков, как и великие мастера прошлых веков, нередко вдохновлялся работами других художников, ведь это никогда не было прямым заимствованием, но всегда переосмыслением, в котором от творческой индивидуальности самого Попкова было больше, чем от первоисточника. Ещё одна очевидная аналогия - работы палехских мастеров, в свою очередь также восходящие к иконописи: именно в то время Попков по-настоящему рассмотрел и полюбил утончённую декоративную изысканность лаковой миниатюры Палеха.

Виктор Попков, довольно быстро проживший в своём творчестве проблематику сурового стиля 
и ушедший дальше в работах, которые не сводятся к тому или иному направлению, считается классическим, лучшим представителем «суровых» во многом благодаря картине «Строители Братской ГЭС».

По словам В. Барвенко, приехавшего в Братск вместе с Попковым, тот был буквально одержим образами рабочих, рисуя этюды с утра до вечера. Загоревшись целью создать по-настоящему монументальное произведение, он стал работать ещё напряжённее, чем обычно. Идея использовать в произведении тёмный - ночной - фон возникла сразу, поэтому этюды к картине писались ночью. По словам самого художника, замысел картины был основан на желании «сделать как в иконах, всех силуэтами на чёрном фоне». Оттого и получились в картине монументальные, «иконные» фигуры рабочих.

В похожем ключе решена ещё одна замечательная работа Попкова - «Бригада отдыхает» (1965), получившая признание в Париже. Её герои не действуют, а пребывают в пространстве картины, погружённые в свои неспешные занятия - чтение, игру в шахматы. Выразительные приёмы здесь ещё более отточены, чем в предыдущем случае: перспективные сокращения отсутствуют (вместо этого фигуры переднего плана помещаются в нижнюю часть композиции, а более удалённые - в верхнюю), а скошенное поле, на котором лежат рабочие, уподоблено условному плоскостному золотистому фону, придающему этой картине сходство - неслучайное - с иконой.

В одном из номеров журнала «Творчество» тогда было напечатано обсуждение картины «Бригада отдыхает» по итогам профессионального круглого стола: некоторые художники высказались недоброжелательно, многие просто недопоняли это произведение. Но сейчас, спустя полвека, очевидно, что находки Попкова не только представляли художественный интерес, но и восстанавливали ещё недавно казавшуюся полностью утраченной возможность диалога с древнерусской традицией. Причём дело было не в заимствовании отдельных мотивов (у Попкова тогда преобладали темы вполне современные), а в попытке осмыслить художественный язык иконописи структуру изобразительного поля, колористические закономерности и т.д.

Особой иконографией пронизана серия «мезенских вдов» Попкова. В центре полотна «Вдовы» изображена в полный рост высокая худая жен- щина, её скорбное лицо с глубокими морщинами напоминает иконный лик или лицо древней деревянной статуи, оно обращено к зрителю, но сдержанная в эмоциях и полная грусти женщина погружена в собственные мысли и воспоминания. Кажется, будто героиня картины сошла с иконной доски, воскрешая в памяти древние иконописные изображения святых мучениц. Это самая яркая фигура из всех, строгая и величественная, она словно колонна держит на себе всю картину. Интуитивно, на ощупь Попков подходит к теме христианского смиренного принятия и несения своего креста.

В натюрморте с серым лоскутным одеялом Попкова примечательно появление иконы, с одной стороны, вроде бы символизирующей связь с традициями, а с другой, - решённой неожиданно нетрадиционно. Приглядевшись к ней, понимаешь, что не можешь узнать изображенный сюжет, что иконографии такого рода не существует и что она, очевидно, целиком придумана художником, возможно, как намёк на необходимость вечного поиска в искусстве.

В картине Попкова «Мать и сын» художник написал себя больным, лежащим в кровати под большим одеялом, а мать изобразил стоящей рядом и читающей Библию. Произведение наполнено теплом и уютом, которые художник ощущал, приезжая к матери. Степанида Ивановна была очень набожна, много лет проработала в церкви звонарём - именно молитвой она излечивает сына, водя пальцем по строчкам из Библии и обращаясь одновременно к сыну и к иконе Божьей Матери в красном углу. Виктор Ефимович никогда не был истово религиозным человеком, но всегда с уважением относился к верующим людям. Мотив материнства присутствует в картине двояко - в образах матери и сына и в иконе Богородицы с Иисусом Христом. Это перекличка с вечной темой Богоматери с младенцем - темой жертвенной материнской любви и молитвенного прошения за сына, которому суждено пронести свой крест.

Удивительно, что именно в Германии им была задумана картина «В соборе», изображающая внутреннее убранство русского храма, словно недолгое пребывание за границей всколыхнуло ностальгию по своему, родному, русскому. ...Мы видим туристов, поднявших головы к фрескам удлинённые, почти бесплотные (не до конца прописанные) фигуры людей сами похожи на почти 
стёртые временем фрески и выглядят менее реальными, чем тени изображений, сохранившихся на стенах собора, - точная метафора эфемерности человеческого существования, преходящего и быстротечного, в отличие от многовековых фресок. К этой картине Попков сделал много карандашных и живописных этюдов с древнерусских росписей.

Особняком в творчестве мастера стоит картина «Мне 40 лет» (1972), написанная, вероятно, под влиянием русской иконописи. Глядя на созданный художником образ можно почувствовать, что сорокалетие стало для автора важным рубежом, поводом осмыслить собственную жизнь и то, что он успел сделать к этому сроку. В центре картины - ангел, бесплотное, почти полностью прозрачное существо с огромными распахнутыми крыльями, который держит в руках голову художника, тогда как тело последнего лежит обезглавленным у его ног. Без головы, с изломанными жестами рук, оно выглядит абсолютно беззащитным, но крыло ангела распростёрлось над ним, как защитная броня.

В другой биографичной картине Попкова «Мой день» (1968) можно увидеть, как полностью рушится система координат, и три образа предстают в обводках, наподобие фресковых образов, приобретая символическое измерение.

Другой пример картины на религиозную тему в творчестве Виктора Попкова - полотно «Северная часовня» (1973). Главный герой здесь маленький мальчик, который выполняет также и функцию зрителя. Помещая его фигуру перед открытой дверью в сакральное пространство часовни, художник тем самым фокусирует внимание на «вхождение отрока в храм, в приобщении к духовному».

В первоначальном эскизе картины «Северная часовня» мальчик (мы видим только его голову) стоит в центре церкви рядом с иконостасом, под куполом, расписанным пёстрыми фресками и занимающим большую часть композиции. Преобладает ликующее настроение: празднично пламенеет красками иконостас; купол, разделённый на сектора - небесно-голубой с красными всполохами фигур святых, - кажется лучащимся и напоминает солнце. Художник выбрал такой ракурс, что зритель чувствует себя разглядывающим купол с запрокинутой головой, вплоть до ощущения лёгкого головокружения - понимая что творится в душе у мальчика. В итоговом ва- рианте присутствуют фигуры, изображённые над входом в часовню. Композиция выстроена так, что в них видятся ангелы-хранители, слетевшиеся к входу, чтобы осенить мальчика и всех входящих. Пространство часовни воспринимается вознесённым над землей домом Божьим, красоте которого дивится мальчик, а дверной проём кажется окном с небес на землю.

Знаковой в этой теме стала и другая картина Попкова «Хороший человек была бабка Анисья». Для усиления плоскостного эффекта, более ярко подающего основную группу персонажей, окончательный вариант картины был написан не масляными красками, а темперой. Но сосредоточение на главном, конечно, не умаляло деталей. По мысли художника, именно возможность рассмотреть детали должна была сделать пространство картины более близким, даже родным для зрителя, а также дать ключ к пониманию общего замысла произведения. В заметках художника встречается такая надпись: «Писать «Бабку Анисью» как цветную гравюру и икону...Лица, как в иконах, охра, лепка, пробела». Действительно, эту «иконность» можно прочувствовать, глядя на картину: персонажи, в плаче прижавшиеся друг к другу, напоминают фигуры с икон, силуэт изображенной со спины фигуры в светлом дождевике подобен силуэту ангела, да и в целом мотив оплакивания, прощания абсолютно иконописный, в качестве возможного прообраза невольно вспоминается Успение Богородицы. Это принципиально другой язык - язык метафизических понятий, который для всякого столетия вне времени.

Интересно, что, обращаясь к проблеме духовных истоков искусства 1960-х годов, А.И. Морозов ставил акцент на внутреннем художественном родстве Корина и Попкова: «Любопытно заметить, что становление Попкова происходило не без косвенного влияния П.Д. Корина. Середина 60-х годов - время, на которое приходился пик популярности старого мастера, связанный с выходом к публике цикла его «Руси». Героини картины «Воспоминания. Вдовы» (1966-1968) - первого шедевра зрелого Попкова - непроизвольно перекликались с коринскими персонажами. Они воспринимались как мощный историконациональный тип, которому не было другой аналогии в нашей живописи». В архиве художника была найдена фотография, запечатлевшая Виктора Попкова среди присутствовавших на отпевании Корина в Успенском соборе Новодевичьего 
монастыря. Это подчёркивает неотрывность духовных и художественных традиций, несмотря на все усилия советских властей вымарать наследие прошлого и построить соцреализм на голом месте.

Одним из примеров обращения «суровых» к религиозной проблематике являются произведения Николая Андронова, в которых художник косвенно использовал библейские мотивы и христианскую иконографию. Путём выстраивания тончайших ассоциаций, сложных намёков, использования иконографических принципов он создаёт некое переплетение, перекличку между евангельскими сюжетами и жизнью обычной деревни. Метафорический смысл у Андронова не всегда лежит на поверхности, но, с другой стороны, абсолютно понятен посвящённому зрителю. Так, например, в картине «Ликбез» (1972) обучение грамоте деревенских жителей прочитывается как распространённая в религиозном искусстве новозаветная сцена «Тайной вечери», а в полотне «Семья» (1976) - евангельский сюжет «Рождество».

В «Ликбезе» на подобную аллюзию указывает число участников, благообразный, как бы списанный с икон, облик крестьян, имитация лазоревых побел на одеждах, характерная пластика персонажей. Стоит также обратить внимание на пространство между двумя центральными фигурами, сидящими спиной к зрителю на первом плане: своими чертами оно похоже на кубок - мотив, распространённый в иконописи и служащий напоминанием о евхаристической чаше. Появляется и такая деталь, как изображение собаки в правом нижнем углу. Собака в композициях «Тайной вечери» часто находилась рядом с Иудой, который разными изобразительными приёмами, но всегда обособлен среди учеников, например, цветом одежды, а в тех случаях, когда все ученики изображались с нимбами, его нимб мог быть написан чёрным или вовсе отсутствовать. Всё это может быть отнесено и к фигуре на картине Андронова, сидящей спиной к собаке, её платок, относительно других героев, художник выделил тёмным цветом. Таким образом, через сопоставление с одним из божественных таинств обучение крестьян грамоте воспринимается как процесс их приобщения к миру духовной культуры. Художник передал состояние постижения тайны, превращения незнающих крестьян в число посвящённых.

В картине «Семья» художник внимательно относится к каждой детали картины и выводит из, казалось бы, бытового мотива образ библейского события. Деревенский быт, таким образом, приобретает особое звучание. Мужской персонаж может восприниматься как Иосиф-плотник и как простой крестьянин, а женский образ как Мария или как женщина-крестьянка. Можно увидеть и два источника света: открытую дверь и мистический свет из яслей. Появление ирреального источника можно связать с традиционной иконографией сюжета Рождества.

В деревенской серии Андронова связующим звеном между миром человека и миром природы выступает окно, соединяя мир быта с миром духовного. С другой стороны, оконная рама становится своего рода границей между человеком и необъятной природой. В этом смысле серия окон Андронова становится символом той уединённой, созерцательной, наполненной внутренней работой жизни, которую художник вёл в Ферапонтове.

Есть у Николая Ивановича автопортреты на фоне икон. Их парадокс заключается в том, что трудно назвать другое произведение в нашем искусстве, где с такой очевидностью узнаётся человек поколения 1960-х годов. В «Автопортрете в музее» герой в своём свитере с крестчатым узором, как и на ризах святого, по духу принадлежит той же почве, что создала древний иконный образ.

Образный мир живописи Николая Андронова представал, как правило, в формах исключительно цельных и концентрированных. Можно невооружённым глазом заметить пронизывающие эту цельность пластические, пространственнокомпозиционные и духовные скрепы, наработанные творческим и человеческим опытом мастера. Осмысление мастером пейзажа XIX века, наследия русского авангарда начала XX века, живописи 1920-х годов сочеталось с глубоким интересом к фреске (Дионисий).

Художнику была чужда недооценка нашей духовной традиции, включая и церковное предание и фольклор, и древние архитектурные памятники - храмы, которые он пишет так часто и истово, и память о любимом Дионисии, и иконы, которые он пристально разглядывает как в музее, так и в деревенской избе. Всё это для Андронова - не просто крупицы памяти, но в огромной степени работа души и испытание живой человеческой совести

Как и у других представителей «сурового стиля», живопись Гелия Коржева во многом 
очищается от второстепенных деталей, и его персонажи не принадлежат этому веку. Среда у Коржева условна в той же степени, что пейзаж иконы. И обобщенная человеческая фигура с сотен его картин - портрет народа, через который в его живописи преломляется эпоха.

Главная, самая известная картина в творчестве художника — «Следы войны». Портрет солдата, прямо глядящего на зрителя единственным пронзительно-голубым глазом, с лицом невинным, обтянутым тонкой обожжённой кожей. Увечный, грязный, опалённый огнём и солнцем человек. Если закрыть одну часть лица - мы увидим мёртвого с заострённым носом, другую - живого, сильного человека. Это почти икона - лицо анфас, без эмоций, фона нет реальность, в которой он находится, не уточнена. «Следы войны» - словно бы негатив картины Дюрера. Тот же монохромный фон, только тёмный. Лицо человека иконописно и прекрасно.

Коржев пережил страну, в которой был признан, тяжело воспринял её развал, но и изменился сам, оставив прежде важные и актуальные темы, и освоил новые. Интересно, что, не будучи воцерковлённым человеком, он после смерти родителей обратился к библейским сюжетам. И это только помогло ему в творчестве. Но художник почти не изменил выработанных ещё в молодости приёмов. Мать на картине 1964 года написана почти так же, как мать в «Несении креста» из библейского цикла 1999 года.

Над этим циклом художник работал четверть века - с середины 1980-х годов и до конца жизни. Начиная разрабатывать библейский цикл или даже чуть ранее, Коржев отдаляется от активной общественной деятельности и становится едва ли не отшельником. Обращение мастера к библейской теме стало продолжением его размышлений об основных духовно-нравственных и философских проблемах и было реализовано с удивительной прямотой. В трактовке сюжетов Ветхого и Нового Заветов главным для Коржева - художника-мыслителя, умудрённого богатым жизненным опытом, - стало выстраивание внутренней логики повествования, исходя из этических и нравственных представлений, определяющих поступки человека.

Религиозно-философская проблематика появляется и в произведениях деревенской серии Павла Никонова. Одним из её решений становится воплощение сюжетов Священного писания в бытовых зарисовках, которые через иконографические ассоциации с библейскими сценами теряют прямолинейность трактовки и приобретают дополнительный смысл. Никонов обобщает фигуры до состояния знаков и доводит пейзаж до состояния условных иконописных горок. Такой перенос евангельских событий в конкретное измерение не был чем-то уникальным: по словам Никонова, когда он задумал серию картин на библейскую тему, он вспоминал о творчестве нидерландского мастера Питера Брейгеля Старшего.

Свою духовную родину Пётр Оссовский обрёл на земле древней Псковщины с её первозданной красотой и суровым былинным величием, удивительной природой и мужественными людьми, что нашло отражение во многих его тематических картинах, приближавшихся к иконным образам. В портретных образах: «Подвижник», «Псковитянка», «Егерь Михаил», «Василиса», «Сибирский старожил», «Мать и отец» он подмечал черты, свидетельствующие о моральной чистоте русского человека, цельности личности, о служении своей земле и вере в своё предназначение. Особое значение имеет серия автопортретов, которую мастер писал на протяжении всей жизни. Наиболее поздний из них - «Автопортрет. Белый квадрат холста», в нём художник заключил серьёзные раздумья о судьбе творческой личности в обществе, её роли и значении.

Земля древнего Пскова, которую Оссовский называет своей духовной родиной, стала для художника источником образов, отображающих не только национальное своеобразие русской провинции середины прошлого столетия, её особую патриархальную атмосферу и самобытность, но и оказывающихся как бы астральными - вне времени и определённого пространства.

Герои произведений Виктора Иванова аскетичны и строги, картины монументальны, в них очевидно влияние иконописи, которой увлекались многие художники «сурового стиля», как и раньше авангардисты (не зря Иванов учился в мастерской бубнововалетовца Александра Осмеркина).

Одна из лучших картин Иванова - «Семья. 1945 год» (1957-1964), рассказывающая о первых днях мирной жизни после победы над фашизмом. Его холст - характерный образец «сурового стиля», изображает торжественную крестьянскую трапезу, где за внешней сдержанностью эмоций скрываются глубокая нежность и радость вновь обретённой целостности. 
В своих последних работах он остаётся верен крестьянской теме и так же безразличен к временным рамкам. Его Косцы (1991) в белых рубахах могли быть написаны и в 1970-е, да и убирающие стога крестьянки с иконописными лицами в Рязанских полях (2005) словно застыли в вечности.

Пейзажи Иванова представляют мир таинственный и беспредельный, природа в них становится молельным образом. Одним из часто повторяющихся мотивов его панорамных пейзажей - изображение на заднем плане храма, стоящего на высоком берегу. Возвышенность эта, как основание для храма, как бы является твёрдым основанием веры.

Между картинами Виктора Иванова существует внутренняя, духовная связь, в них он отражает устойчивость, весомость жизненных явлений. Отсюда композиции, сила цвета, наполненность всей формы. Произведения художника посвящены людям современной деревни, но он не является её бытописателем. Деревенская жизнь, труд людей - это тема, пронизанная единым замыслом, через которую Иванов несёт зрителю свои взгляды на мир, высказывает идеи времени, утверждает свои идеалы.

Многие критики причисляют Дмитрия Жилинского к художникам «сурового стиля», однако сам мастер считал, что он «только жил одновременно с ними». Тем не менее, многое и роднило художника с коллегами по направлению. В своём творчестве Жилинский обратился к наследию древнерусской иконописи, а также итальянского и Северного Возрождения. За каждым явлением, героем или предметом в его картинах скрывается целая история, полная метафорических уподоблений, символов и аллегорий. Произведениям этого мастера свойственна насыщенность символами, в его полотнах нет случайных деталей.

Один из самых проникновенных в творчестве Жилинского - образ матери, Анастасии Фёдоровны. Наиболее ярко он представлен в картине «Под старой яблоней» (1969), посвящённой трагической истории семьи художника. В качестве основы Жилинский использовал доску, подготовив её по образцу иконы, в ковчеге - углублённом среднем поле на лицевой стороне доски изобразил свою мать и детей, а на полях поместил фигуры отца, расстрелянного в 1937 году, и брата, погибшего на фронте в 1944 году. Сопоставление плодоносящего дерева и женщины в окружении внуков становится метафорой несокрушимой жизненной силы. Картина в своей выкрашенной белой краской широкой плоской раме с размещёнными на ней двумя изображениями вызывает в памяти древнерусские иконы с клеймами на полях. Техника, в которой выполнено произведение (темперными красками по левкасу), также идёт из древнерусской иконописи.

Чрезвычайно выразителен офорт Владими-

ра Дайчмана «Сикстинская мадонна», выполненный в духе «сурового стиля». Вертикальный формат листа подчёркивает узкое пространство бункера, где в варварском небрежении складированы холсты. Ступени пыльной лестницы ведут вверх. Там, в проёме распахнутой двери, - красноармеец с автоматом. Лучи солнечного света выхватывают из темноты лик Мадонны с ребёнком. Динамичность сцене придают разворот фигуры солдата, контраст яркого света, льющегося с улицы, и темноты помещения, особый характер штриха. Эта картина - как символ постоянной борьбы советского варварства и неприятия традиций против вечной красоты иконных образов и великих живописных произведений, ставших иконографичными.

К сожалению, у «сурового стиля», возникшего в пику бесконечным изображениям ликования советских праздников и парадных портретов вождей, были свои слабые стороны. Многие его адепты со временем стали заложниками собственной художественной программы: поиск лаконичной простоты часто приводил к известной выхолощенности и схематизации образов, а стремление к монументальности иногда оборачивалось равнодушием к деталям и гиперболизацией изображаемого. Парадоксально, но с течением времени мастера этого стиля, изначально ставившие своей целью отражение правды жизни, всё чаще стали создавать в своих работах своеобразную трудовую мифологию, по сути, впадая в то же мифотворчество, против которого некогда боролись. Обретённая новизна, свежий взгляд на жизнь со временем вырождались в клише.

Однако лучшие работы этого направления, в которых особенно ярко прослеживается связь с иконописью, являются замечательными примерами творческой свободы. В них художники не оглядывались на идеологические указания, для многих из них таким творческим маяком была русская икона с её чистыми красками, лаконизмом, правдой. Именно этими чертами представители «сурового стиля» наделяли картины, которые стали явлением советской эпохи 1960-1970-х и пробивались 
к зрителю, как свет иконы пробивается сквозь стены к верующему человеку.

Образы в этих работах не индивидуализированы, а, скорее, обобщены, однако пониманию душевного состояния персонажей это никак не мешает, может быть, даже наоборот - делает его более чистым, отрешённым от конкретных примет реальности, и потому более глубоким. Стремление художников отобразить неотобразимое закономерно становится в этих картинах сродни задачам, которые веками стояли перед русскими иконописцами.

Художники «сурового стиля» через метафорический живописный язык возвращали оторванному от корней советскому народу исконные традиции русской жизни, в которой икона всегда проходила центральной осью, была фундаментом, скрепляющим основы духовной жизни.

Но схожесть с иконой была не только в изобразительных, духовных и философских смыслах, но проявлялась ещё и в социальной роли больших полотен живописцев «сурового стиля», стано- вившихся своего рода образцом для подражания. Монументальность, плакатность, крупноформатность, лаконизм и экспрессия - всё это придавало полотнам остроактуальное и, вместе с тем, эпическое, высоко гражданственное звучание. Картины оказали, безусловно, высокое влияние на кинематограф и живопись последующих десятилетий, ставя новые вопросы нравственного и этического толка.

Будучи русскими по рождению, художники «сурового стиля» вышли, возможно, сами того не ведая, на уровень больших национальных художественных обобщений, сделанных ими на материале сугубо русском, исходя из собственного опыта и знания жизни своего народа.

«Суровый стиль» - явление, которому так безапелляционно присваивали статус чего-то эпизодического, даже мимолётного, оказалось в разных вариантах совместимым с актуальными во все времена философскими и религиозными постулатами, национальной идеей, влечением к вечности.

\section{БИБЛИОГРАФИЯ}

1. Алексеева Т.П. Образы народа и судьбы индивидуальности в живописи сурового стиля [Текст] / Т.П. Алексеева, Н.В.Виницкая // Культурное наследие Сибири.- 2017.- Т. 3. - № 21.- С. 40-45.

2. Библия глазами соцреалиста. Гелий Коржев [Текст] $=$ The Bible througt the eyes of a socialist realist. Gely Korzhev: каталог выставки, 12 декабря 2012-27 мая 2013 / [текст К. Карпова]. - Москва: Сканрус, 2012.127 с.: ил., портр., цв. ил.

3. Бобриков А.А. Суровый стиль: мобилизация и культурная революция [Электронный ресурс] / А.А. Бобриков // Художественный журнал.2003. - № 51-52. - С. 29-33. - Режим доступа: http:// moscowartmagazine.com/issue/57/article/1137 (дата обращения: 31.12.2020).

4. Бондаренко, Л.К. Тема деревни в творчестве советских живописцев 1960-1970-х годов: дис. ... кандидата искусствоведения: 17.00.04 [Текст] / Бондаренко Людмила Константиновна; [Место защиты: Моск. гос. акад. Худож. ин-т им. В.И. Сурикова].- Москва, 2005. - 193 c

5. Бурганова М.А. Суровый стиль: прямая речь [Текст] / М.А. Бурганова // Дом Бурганова. Пространство культуры.- 2008. - № 1.- С. 8-33.
6. Буткевич Д. С уклоном в суровый стиль [Текст] / Д. Буткевич // Независимая газета.- 2006.- 27 января.- С. 3.

7. Дехтярь А. А. Павел Никонов [Текст] / А. Дехтярь.Ленинград: Художник РСФСР, 1981.- 69 с.: ил.

8. Зайцев Е. В. Гелий Михайлович Коржев: [Альбом]: К 75-летию со дня рождения [Текст] / Евгений Зайцев; [Рос. акад. художеств. Науч.-исслед. ин-т теории и истории изобраз. искусств]. - Москва: Пассим, 2000.- 111 с.

9. Виктор Попков [Текст] / [текст: Козорезенко П. П. мл.; фот.: Кубарев В. Г.].- Москва: [б. и.], 2012.- 457, [6] с.: ил., портр., цв. ил.

10. Волошина И. Виктор Попков: Художник на вдовьей земле [Текст] / И. Волошина // Фома.- 2015.№ 12.- С. 62-71.: ил.

11. Время перемен: искусство 1960-1985 в Советском Союзе: [каталог] [Текст] / Государственный Русский музей. - Санкт-Петербург: Palace Editions, 2006. - 415 с.: ил., цв. ил.

12. Matthew Cullerne Bown. Art under Stalin.- Oxford, Phaidon Press, 1991.

13. Realismi socialisti. Grande pittura sovietica 1920 1970. - Milano, Skira, 2011. 
Nikolay P. Beschastnov

Doctor of Art History,

Professor of the Department of Drawing and Painting

of the Russian State University of A. N. Kosygin (Technology. Design. Art)

e-mail: npb.art@mail.ru

Moscow, Russia

Evdokia N. Dergiliova

Candidate of Art Criticism,

Associate Professor of the Department of Decorative and Applied Arts and Artistic Textiles of the Russian State University of A. N. Kosygin (Technology. Design. Art)

e-mail: dysua@mail.ru

Moscow, Russia

\section{MOSCOW METRO OF ALENA DERGILIOVA: IMAGE OF STABILITY AND FEATURES OF CHANGE}

Summary: The article focuses on the study of graphic works depicting the life of the Moscow metro, created in 1980-1990 by the Moscow artist Alyona Dergiliova. The etchings convincingly reflect the life of our people on the threshold of national historical development. In her complex, variously sized, drawn from life compositions with many figures in motion, the artist mastered the whole range of compositional and visual devices that she would use in her narrative watercolours of the 2000s. She found the contrast of the pathos in the metro interior - stations with a bustling motley crowd of Muscovites deep in themselves and rather shabby travellers from the depths of the Russian backcountry - which became the counterpoint for her further creative search for the image of Moscow. Investigation of resources, experiments in methods of taking the motion of subjects beyond the boundaries of the compositional plane, allow the series to be included in the list of artistic experiments relentlessly carried out by Dergiliova despite the years of difficulties in her creative life.

The theme of 'A Man and His City' is apparently simple but it is resolved in a multitude of complex relationships carried from life on the squares of Moscow over to the interiors of its underground. People above and underground are the same, with their acquired strangeness, yet their psychological state in a confined space is different. The environment - albeit imperceptibly - changes

The metro occupies an extraordinary place in the life of Moscow and all of Russia indeed. It was the first metro system in our country, and numerous visitors along with their children, came to the people. It is vibrant all the same, but in a different way. The architecture inside the metro is closer to the person, and Dergiliova successfully uses this aspect in building her composition. The compositions include many recognizable details of architectural decor which complement the central narrative. These details are clues helping the viewer to figure out its meaning. The characteristic feature of the metro is motion, and the artist draws numerous human figures, figurative stucco elements, sculptural compositions, chips and cracks in the steps, chandeliers swinging at the arrival of the subway train - into an endless cycle.

Scenes depicting the entrances to the metro is a separate theme, which is almost non-existent in Russian art. By rendering the entrances as energy hubs - breaches between the aboveground Moscow and its underground Dergiliova fills them with particular meaning, as all these people, drawn by a skilful and confident hand, will have to squeeze into the endless corridors and noisy subway wagons rattling on rails.

Careful analysis of the artist's creation reveals the disturbing condition of the master's soul. The condition which the masters of art were firmly in for the entire decade after the events depicted in these works.

Keywords: Alena Dergiliova, city, Moscow, metro, composition, etching, graphics, artist, architecture, interior, sculpture, columns, trade, metropolis, urban transport.

city to enjoy the ride on the 'magic stairway'. During the Soviet era, and even now, Russians take long trips through Moscow and, naturally, travel by its 'underground'. 


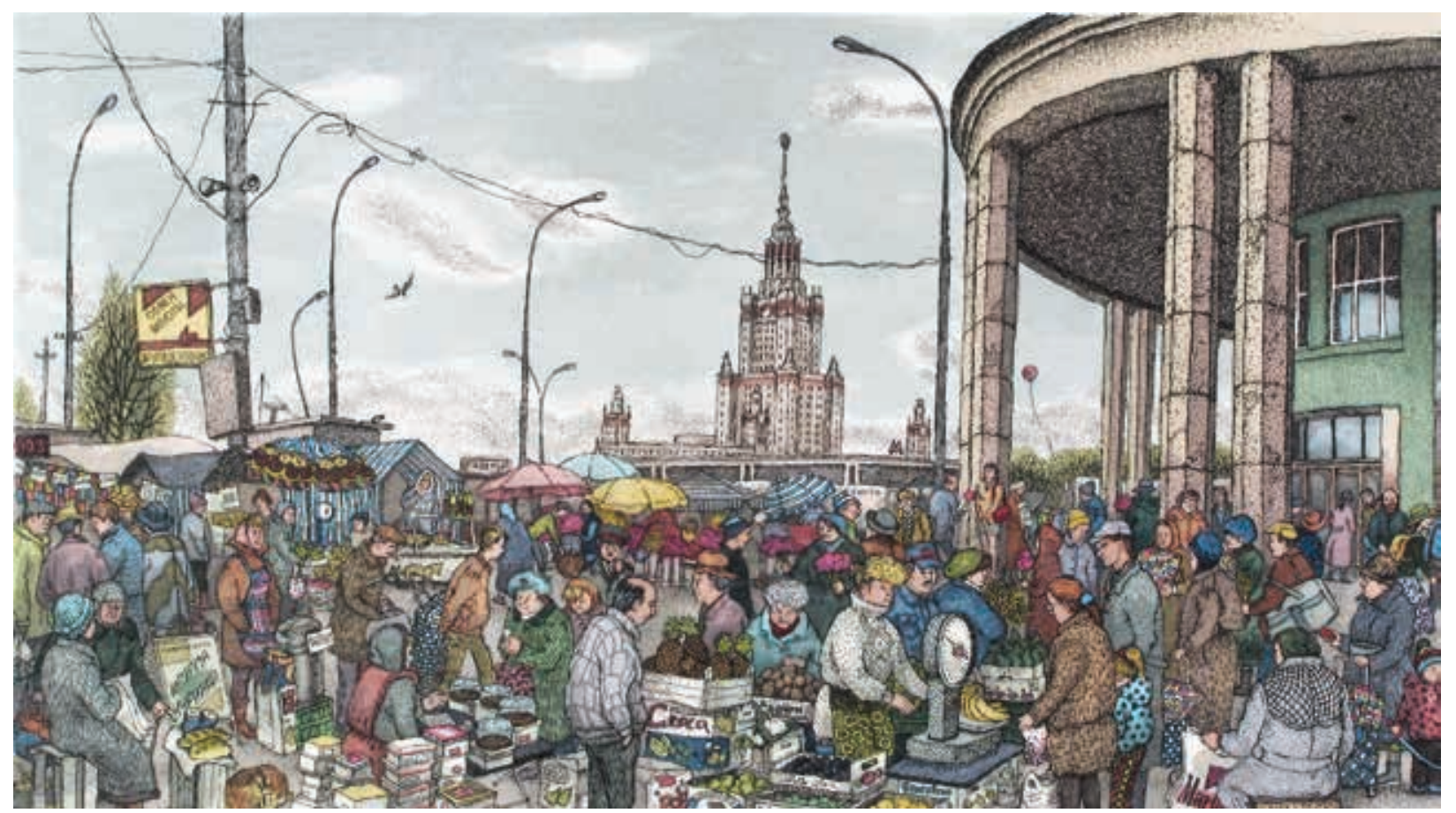

IIl. 1. Alena Dergileva. Universitet metro station. Etching, watercolor. 20×30. 1997

The Moscow metro is the pride of the inhabitants of the metropolis, it simply cannot but be reflected in the fine arts. Paintings and graphic works are regularly displayed at various art exhibitions, sporting the bright letter ' $\mathrm{M}$ ' at underground passages, or depicting faceless flows of people in escalator 'pipes'. These are mostly episodic works built around some scene in the subway that impressed the artist, or the beauty of the interiors of central stations. There are only a few artists who create series works, and Alena Dergiliova is one of the best.

Alena Dergiliova is widely known as the author of large-format watercolours of 'My Moscow' series, in which she reflects the panorama of life of the squares, streets and alleys of our ancient yet rapidly developing city. Her early etching series, less known today, hit the exhibitions at the end of the last century. They became a part of our history and ended up in museum collections. The compositions with the stations of the Moscow metro in these series are one of the most original [1-3].

'Moscow metro' series was completed in the late 1980 s and in the 1990s. It ties up with the artist beginning to explore the hub zones of the 'aura' of the metropolis built above and underground. The Moscow metro is a unique transport artery, conceived as a government-owned system of underground palace-like stations for the public before the Great Patriotic War. Further out from the centre the metro sheds its grandeur, but the stations still gleam with marble and granite. The metro embodies the concepts of motion, movement and change. In the 'chaotic nineties', when many things turned into one big problem, it didn't fail to work properly and brought hope that someday the order would be restored. The metro became not only an extremely reliable workhorse, but also one of the singular symbols of hope for positive changes in Russian society. Everyone was in a hurry, dragging huge bales along the granite steps of the subway, peddling goods above and underground. Metro squares turned into huge flea markets with grocery stalls mingled in as well. Strange-looking people tried to offer you something right in front of the trains and even inside them. The unsettled life has thrown paupers 'robbed' at the train terminal, crippled 'heroes' of all the wars in the world, and homeless people into the subway cars. We did not see them in Soviet Moscow, since the homeless were considered an unemployed class, caught by the police and driven out of the city limits. In the 1990s, half of the country was not paid, homeless people flocked to the underpasses at metro stations gathering into reeking rookeries, previously described in the pre-revolutionary works of V. Gilyarovsky and M. Gorky in scenes on the Khitrov market. But then such rookeries only existed in the dead-ends of unpopular nooks of the city, and presently they reemerged at the popup markets near the metro. Both the active part of the population and completely downtrodden people were drawn to the warmth and the pulse of life. 


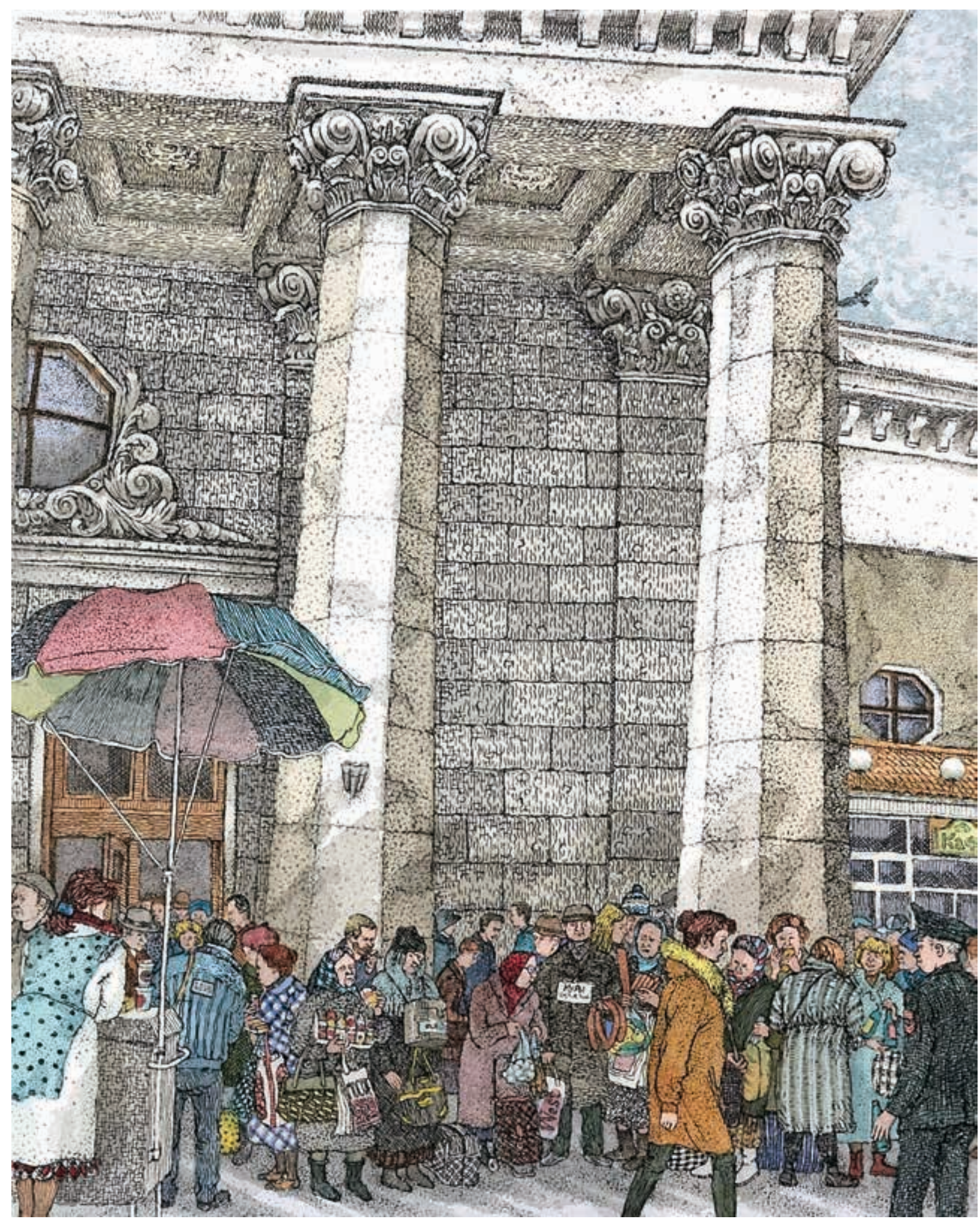

IIl. 2. Alena Dergileva. At the Komsomolskaya metro station. Etching, watercolor. 25.5×20.5. 1997

In 1997 Dergiliova painted one of these markets which was in full swing at the 'Universitet' station. The largest and the most laborious composition in the entire series is 'At the Universitet metro station'. It depicts roughly threescore of our fellow citizens, trading and buying both as of mundane necessity and of dire want on one cold autumn day. The basic trading equipment - boxes on which to sit, lay out the goods and weigh the product. They boxes are also used to carry vegetables and fruits. Most popular goods: bananas, pineapples, potatoes and tomatoes. In those years bananas and pineapples for some reason went at the price of produce from the Russian soil, which was at that time quite surprising 
and frighteningly incomprehensible. People recalling their childhood dreams eagerly bought the exotic fruits. Perhaps that is why the process of procurement of a bunch of bananas by the artist herself is one of the main scenes of the market stretching off into the distance. In fact, we see a collective portrait of the impoverished people of Moscow and cities around it of the late 1990s. Each character is unique, as the composition is based on life sketches.

This cycle of sale and purchase, against the background of a clear sky with white cirrus clouds, is strongly dominated by the columns of the aboveground part of the metro station building, a street pole with loudspeakers and the skyscraper of Moscow State University, which appears almost white due to ambient light and atmospheric conditions. There can be no doubt that all this is happening in Moscow - the capital of our Motherland - with the symbols of sovereignty of the 'Soviet Country' steadfast in their proper places. However, the people's faces in the crowd are far too serious, but the general air is brightened up a little by the vivid colours of beach umbrellas brought from Turkey, used to protect against fleeting, yet very angry rains (Fig. 1).

'At the Komsomolskaya metro station' - an etching in an almost perfectly square shape - is an attempt to take a snapshot of Moscow life at the 'Three Terminals' square. A joint complex consisting of metro stations and three of the country's largest railway terminals lives its own special life of 'trunk and transfer'. Passengers who had got tired of sleeping on the hard bunks of railcars or sitting on the wooden benches of commuter trains, meet an army of hawkers of both sexes and all ages who are selling cigarettes, 'Chicken hot!', hand-made shopping bags with the 'Moscow - 850 years' logo, Krakow sausage and some intoxicating substances as well. Visitors of Moscow hardly making their way through the dense crowd dive into the depths of the metro. One can often miss the glimpse of the cyclopean entrance hall of the Komsomolskaya metro station with its huge capitals somewhere above, apparently meant to amaze the visitor from the outback. Voluminous luggage in the hands of travellers also contributes to the sensations of meeting the capital, transferring most of their thoughts from their heads to the handles of suitcases, bags and trolleys (Fig. 2).

As in the composition 'At the Universitet metro station', Dergiliova uses the method of juxtaposition of the grandiose architecture, which embodies the inviolability of the state, and the vanity of the mundane existence of the common man. But if the first work is a symbol of trading Moscow, the second is of Moscow trading and travelling. The first work is built as a horizontal epic canvas - a bustling sea of people under a huge dome of the sky, the second - as a fragment of an endless human stream. The stream pours out of the picture plane, and the artist 'snatched out' but one of its characteristic sections. We know that the crowd mass spills forth to the platforms near the electric trains and into the 'bowels' of the metro.

Metro stations in the outskirts of Moscow are presented in a series of compositions with halls of 'Prospekt Vernadskogo' and 'Yugo-Zapadnaya'. 'Prospekt Vernadskogo' station is depicted at the beginning of a warm autumn on a Sunday. The premise is typical for the new areas of 'concrete' Moscow: residents of high-rise buildings slowly emerging from the underground, overhead trolley wire suspension cables on pillars, buses, furs and sheepskin coats ads, 'heaping' groups of men of uncertain nationality, women selling fresh bread, apples, peaches and watermelons, and dogs reclining on the warm asphalt. Children playing with balloons, with the coveted McDonald's sign and its golden arches logo echoing the letter M symbol of the metro.

The rectangular glass building of the aboveground hall of 'Yugo-Zapadnaya' station is contrasted by the author to the thick dough of moving people. The market at the station was already in full swing in those years, minibuses parked there bound out to the boroughs, but the modern staggering cycle of people and transport was not there yet. The author lived one stop away from the 'Yugo-Zapadnaya', and she often visited this trade fair which, although a bit dirty, offered relatively high-quality products. It was cheaper than the one at the 'Universitet' because of its location and the significant percentage of workers from former Soviet collective farms. The place was obviously noisy, but the residents loved it, and her local friends asked Dergiliova to capture the scene in its summer and winter shape. To tell the truth, these local friends were foreigners.

In the summer version, the area around the station is presented as a district scale transport hub a peripheral centre of the city. The circular layout of figures at the steps of the station and the complex social composition of the actors are expressions of that. The central part of the composition is occupied by a group of labour people moving towards the en- 


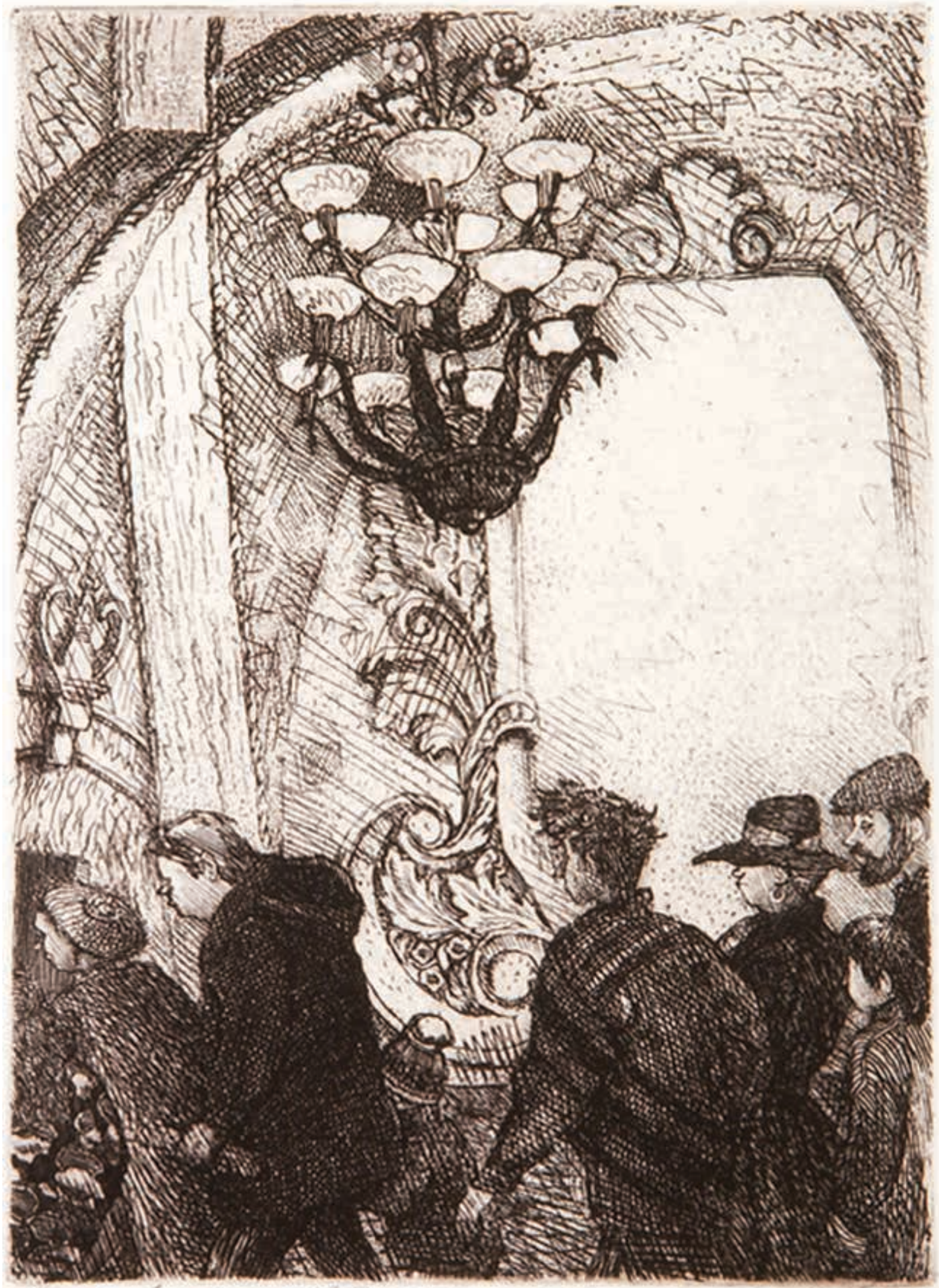

Ill. 3. Alena Dergileva. Arbatskaya metro station. Etching, watercolor. 12×9. 1997

trance of the station. Their figures are made a little larger and more energetic. Dense crowd of elderly people serve as the background, selling plants and flowers grown in their private gardens. Someone is talking on the large cell phone, someone is chewing a pie on the go or dragging a heavy briefcase. The 
winter version is more deserted, and this time you can see the bus stops, their walls covered with tiny bills with various offers. Figures of mindful women in beautiful coats and fur coats with household bags in their hands are clearly outlined against the background of men in bluish padded snow jackets. The women want to be beautiful and, at the same time, feed their family. It's cold, and people try not to linger.

The underground interiors of the subway are depicted in the etchings with the following stations: 'Park Kultury', 'Belorusskaya', 'Arbatskaya', 'Baumanskaya', 'Dinamo', 'Ploschad Revolyutsii', 'Kurskaya' (Fig. 3, 4). Passengers underground are extremely immersed in themselves and detached from the environment. They are alone among the crowd. Someone is struggling to read on the move with varying success, the other one is surprised at the sparrow, which heaven knows how got underground and perched atop the head of a sculpture. But everyone is a part of the endless flow in immense human ducts. Children, old men and women, blooming young ladies and strong men move in the haze of artificial light in fur coats, cloaks, jackets, strange knitted berets and ushanka-hats worn by men and women alike.

The etchings of the 1980s show the average look of the Soviet man from the 'late socialism' period. Men 'over forty' carry 'avoskas', a type of handy fishing net bag, clearly displaying its contents of simple foodstuffs and a fresh newspaper. So what? An honest Soviet man has nothing to hide, although there is nothing to be proud of either...

When you're in a metro wagon and there is no cram, then you have only three types of entertainment: to doze, to read or just flip over the pages, or to eye your fellow travellers unobtrusively. Everyone examines everyone, since Muscovites are very curious by nature. This examination process turns on intuitively as soon as you approach the oversize poster with a map of Moscow metro. The etchings show not a single scene inside the wagon, still you continuously scan the composition, looking for something in front of you. In hundreds of depicted people, Dergiliova's acquaintances recognize their relatives and even themselves, as the author often includes familiar images in their usual setting. Generally, she draws her friends in the background or from the side. It is difficult to recognize them, since these are, of course, not accurate portraits, but typical images, which they acknowledge by saying: 'And I don't have such an old hat!' Of course, they have this hat, but are reluctant to admit that; from the side, it looks cute, but a bit ridiculous.

A special theme in the etching compositions is the plastic relationship between sculptural decoration and living moving people. Our people have changed since the time central station-palaces were built. New artificial and synthetic materials with modified viscose or Lycra actively influenced the plasticity of the dressed figure, gait and even demeanour. In the 1980s, these synthetic clothes were just entering fashion, but the achievements of European and American fashion houses of 2000s finally took root in Russia. However, in subway wagons you can still see young people from the provinces in domestic knitted hats with 'adidas' or 'forward' lettering; as before, plump women are waiting for someone standing next to the sculptures of workers in caps with hard peaks, putting their bags at the labour hero's feet. An image of a police officer is outlined from background of the crowd on 'At the Kurskaya station' etching. Despite his central location, he is also immersed in his 'police' thoughts. Only the stiffness of the figure reveals his 'alert condition', which makes him look at the passengers through the slits of his eyes. 'The horn of abundance' in the form of a column covers the action as a gigantic umbrella. Pre-war and post-war sculpture in the metro lives its own troubled life. Concrete sculptures of partisans with machine guns and marines with pistols greet and accompany Muscovites and visitors of the capital, while dancing couples in light clothes on high reliefs nonchalantly swing among passengers dishevelled by the Moscow weather. 'Stone guests' and their bronze 'friends' have long ceased to bother Muscovites, they even like them... Even such stations, fantastic in terms of the sheer number of sculptures, such as 'Ploschad Revolyutsii', are in the cultural context of the time. The sculpture is in harmony with the architectural exterior ornament that has penetrated the interiors of the metro. Its bold baroque-empire style curls are perceived as elements of the life of giants who once lived. They are disproportionate to the slightly crumpled passengers who jumped out of the subway wagon, both in form and in pathos of content. The author reflects on the existing visual conflict in the 'Metro Arbatskaya' etching, depicting hurrying Muscovites against the background of a huge white high-relief frame, which previously contained the image of Joseph Stalin in the 1950s. It seems that the glow coming from the centre of the image smeared with 


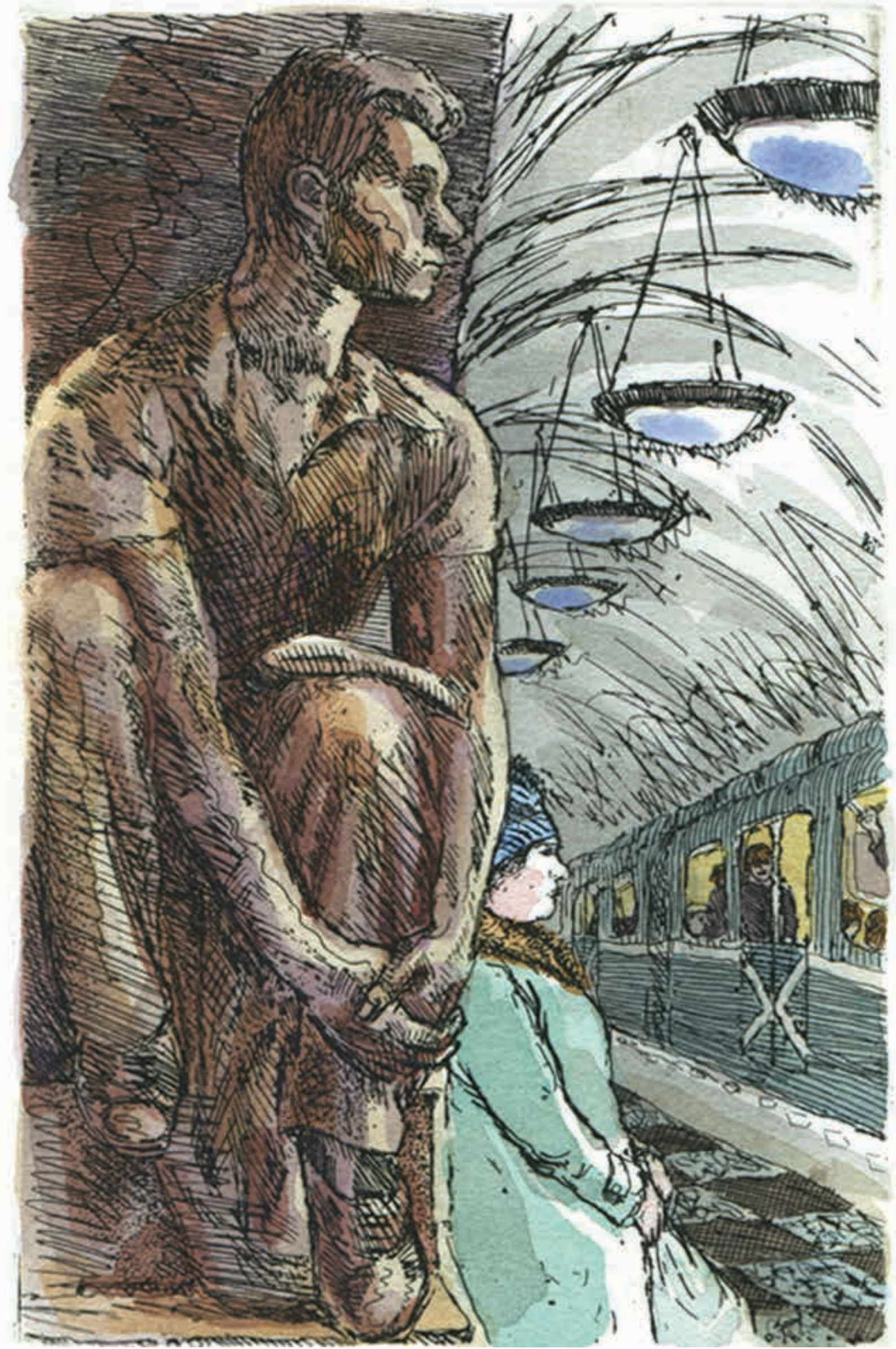

Ill. 4. Alena Dergileva. Ploshchad Revolyutsii metro station. Etching, watercolor. 12×9. 1996 
plaster makes even the descendants of the people who were under Stalin's rule, to shrink and increase their pace.

There is always a lot of provincialism and naivety in Moscow, despite the desire for sophistication. The Moscow merchants threw themselves to the extremes, which was manifested in the eclecticism of architecture. The same fate befell the architecture of the Bolsheviks who moved from St. Petersburg to Moscow, and the metro is the confirmation to this. Cold 'hi-tech' style takes root just as badly in the Moscow subway and demands some time to accustom for the Muscovite's nature. It is most likely, that Moscow traditionally gravitates towards the eclecticism and is not intimidated by sensational diversity. Different cultures and epochs have united in it, and they will be entwined with the sprouts of a new life that is not fully formed yet. The absurd and the awkward, the artistic and the sublime, merging and getting mixed, create nutrient soil for 'the unknown tomorrow'.

They say that you have to be in love with the Moscow metro. It very well may be. After all, if you love, then you forgive many of the original and acquired shortcomings and admire the undoubted advantages. The metro is a reflection of ourselves, restless and naive, conservative and strangely radical, sophisticated and gaudy.

All compositions dedicated to the metro were drawn by Dergiliova on zinc plates directly from life.
To say that drawing in the subway requires a great deal of effort would be almost an understatement. There is simply no room for the artist to work both physically and psychologically. The metro of the last decades of the past century can be compared with the hyper-excited nervous system of a person on the verge of a breakdown. It is simply inconceivable to imagine how it was possible to draw there. But that is just what she did. The analysis of the compositions shows us that they were conceived and executed from life. The fragmentary frame view sections of the underground circulation caught by the author's eye, and multi-textured scenes at the entrance to the metro - were created while she was standing among Muscovites who were stunned by the hardships of life.

Studying the 'underground' etching series of a score of different-sized compositions made by Dergiliova, we can affirm that it was in them that the talent of the graphic artist and the 'scene writer' was most vividly revealed. Scores of people depicted in motion, skilfully drawn into complex compositional constructions of horizontal, diagonal, circular types and their combinations, create that transitional time context, which is read by the viewer as a deeply meaningful text filled with disturbing sensations. This cannot be done after the fact; it can be created only from within the events.

\section{REFERENCES}

1. Beschastnov, N. P. 2020. "Painted Moscow by Alena Dergiliova. City images", Architecture, construction, design, no. 01/02, pp. 102-107.

2. Dergiliova, A. I., A. G. Mitrofanov Moscow: Home Album.- Moscow, which is not there, 2011.- p. 168.

3. Dergiliova, A. I. 2017. Painted Moscow, Moscow, p. 264.

4. Balik, Gökhan, Lökçe, Deniz Balık. 2019. "On the Relationship of Landscape and Painting", AM Journal of Art and Media Studies, no.19, pp. 29-44 DOI: http://dx.doi. org/10.25038/am.v0i19.305 (in English)
5. Häyrynen, Maunu. 2014."Lost Landscapes: Degraded Landscape as Anti-Landscape.", The Anti-Landscape, edited by David E. Nye and Sarah S. Elkind, pp. 149158. Leiden: Rodopi (in English)

6. Somhegyi, Z. 2019. "Pages and Full Stops: On the Aesthetic Relation between Books and Art", AM Journal of Art and Media Studie, no. 19, pp. 69-75. (in English) DOI: http://dx.doi.org/10.25038/am.v0i19.306 
Николай Петрович Бесчастнов

доктор искусствоведения,

профессор кафедры рисунка и живописи

Российского государственного университета им. А. Н. Косыгина

(Технологии. Дизайн. Искусство)

e-mail: npb.art@mail.ru

Россия, Москва

Евдокия Николаевна Дергилёва

кандидат искусствоведения,

доцент кафедры декоративно-прикладного искусства и художественного текстиля

Российского государственного университета им. А.Н. Косыгина

(Технологии. Дизайн. Искусство)

e-mail: dysua@mail.ru

Россия, Москва

DOI: 10.36340/2071-6818-2021-17-2-101-113

\section{МОСКОВСКОЕ МЕТРО АЛЁНЫ ДЕРГИЛЁВОЙ: ОБРАЗ СТАБИЛЬНОСТИ И ЧЕРТЫ ПЕРЕМЕН}

Аннотация: Статья посвящена исследованию графических произведений с изображениями жизни московского метро, созданных в 1980-1990 годах московским художником Алёной Дергилёвой. Офортные листы убедительно отражают жизнь нашего народа в переломный период развития отечественной истории. В разноразмерных отрисованных с натуры сложноорганизованных композициях со множеством движущихся фигур художником был отработан весь спектр композиционно-образных решений, которые она будет использовать в сюжетных акварелях 2000-х годов. Найденный контраст пафоса убранства метро - станций с суетящейся, углублённой в себя разношёрстной толпой москвичей и порядком пообтрепавшихся путешественников из российской глубинки, стал контрапунктом для её дальнейших творческих поисков в изображении Москвы. Ресурсные поиски, эксперименты по приёмам выведения движения людей за границы композиционной плоскости позволяют включить серию в реестр художественных экспериментов, упорно проводившихся Дергилёвой несмотря на тяжелые для творчества годы.

Внешне простая тема «Человек и его город» решается во множестве сложных взаимоотношений, переходящих из жизни на площадях Москвы в интерьеры Москвы подземной. Люди на земле и под землёй одни и те же, со своими благоприобретенными странностями, но их психологическое состояние в замкнутом пространстве уже другое. Среда пусть неуловимо, но меняет человека. Она такая же живая, но другая. В метро архитектура ближе к человеку, и Дергилёва это успешно использует при построении композиций. Композиции включают в себя множество узнаваемых деталей архитектурного убранства, дополняющих основной сюжет. Эти детали - подсказка зрителю при «разгадывании» смысла сюжетного действа. Характерная черта метро движение, и художник вовлекает в бесконечный круговорот множество человеческих фигур, фигурную лепнину, скульптурные композиции, сколы и трещины в ступеньках, качающиеся при прибытии метропоезда светильники.

Отдельной, почти не встречающейся в нашем искусстве темой являются композиции, изображающие входы в метро. Трактуя их как энергетические узлы прорывы между Москвой надземной и подземной, Дергилёва наполняет их особым смыслом, т. к. все эти люди, отрисованные умелой уверенной рукой, должны будут втиснуться в бесконечные коридоры и шумящие, стучащие по рельсам вагоны.

Внимательный анализ созданного художником позволяет увидеть тревожное состояние души мастера. Состояние, которое не отпускало мастеров искусства целое десятилетие после изображённых событий.

Ключевые слова: Алёна Дергилёва, город, Москва, метро, композиция, офорт, графика, художник, архитектура, интерьер, скульптура, колонны, торговля, мегаполис, городской транспорт. 
Метро занимает выдающееся место в жизни Москвы, да и всей России. Оно было первым в нашей стране, и многочисленные гости столицы вместе с детьми приезжали в город ради того, чтобы прокатиться на «лестнице-чудеснице». В советские годы, да и сейчас, россияне осуществляют дальние поездки через Москву и, конечно, проезжают по её «подземке».

Московское метро - гордость жителей мегаполиса, просто не может быть не отражено в изобразительном искусстве. На художественных выставках периодически экспонируются картины и графические листы с изображениями яркой буквы «М» у подземных переходов или безликим людским потоком в «трубах» эскалаторов. В основном это эпизодические произведения, построенные на поразившей художника сцене в метро или красоте интерьеров центральных станций. Мастеров, создающих серии работ, немного, и один из лучших - Алёна Дергилёва.

Алёна Дергилёва широко известна как автор большеформатных акварелей «Моя Москва», в которых панорамно отражена жизнь площадей, улиц и переулков нашего древнего и быстроразвивающегося города. Менее известны сегодня её ранние офортные серии, которые прошли по выставкам в конце ушедшего века, стали частью нашей истории и осели в музейных собраниях. Композиции со станциями московского метро в этих сериях одни из самых оригинальных [1-3].

Серия «Московское метро» была исполнена в конце 1980-х -1990-е годы и связана с началом художнического изучения автором узловых зон «ауры» построенного на земле и под землей мегаполиса. Московское метро - уникальная транспортная артерия, задуманная как государственная система подземных дворцов-станций для народа ещё до Великой Отечественной войны, приближаясь к окраинам Москвы, теряет помпезность, но по-прежнему сверкает мрамором и гранитом. Метро - олицетворение движения, перемещения, изменения... В «лихие девяностые», когда многое превратилось в одну большую проблему, оно работало бесперебойно и порождало надежду на восстановление порядка. Метро стало не только сверхнадёжной рабочей лошадкой, но и одним из своеобразных символов надежды на положительные изменения в российском обществе. Все куда-то спешили, тащили огромные тюки по гранитным ступенькам подземки, торговали с рук на земле и под землёй. Площади у метро преврати- лись в огромные барахолки, смешанные с продуктовыми рынками. Странного вида люди пытались что-то предлагать даже у метровагонов и в самих вагонах. Неустроенность жизни выплеснула в вагоны метро попрошаек, «обворованных» на вокзале, «героев»-инвалидов всех войн на свете и «бомжей». Мы их не видели в советской Москве, так как «бомжи», как неработающий контингент, отлавливались милицией и выдворялись за городскую черту. В 1990-е годы не получала зарплату добрая половина страны, и в переходах у метро стали образовываться смрадные «бомжележки», зафиксированные в дореволюционной литературе В. Гиляровским и М. Горьким в сценах на «Хитровом рынке». Но тогда они существовали в тупиковых-»неходовых» углах города, а теперь возродились у стихийных рынков у метро. Активная часть населения и полностью опустившиеся люди тянулись к биению жизни и теплу.

Один из таких рынков, кипевших у метро «Университет», Дергилёва нарисовала в 1997 году. Композиция «У станции метро «Университет» является наиболее крупной и многодельной из всей серии. На ней изображено около шестидесяти наших соотечественников, торгующих и покупающих как по жизни, так и по жестокой нужде холодным осенним деньком. Основной торговый инвентарь - ящики, на которых сидят, раскладывают товар и производят взвешивание продукта. В них же подтаскивают овощи и фрукты. Самый ходовой товар: бананы, ананасы, картошка и помидоры. Бананы и ананасы почему-то стали в те годы «идти» по цене даров земли российской, что было тогда удивительно и пугающе непонятно. Помня о мечтах детства, их покупали бойко. Возможно, поэтому процесс приобретения связки бананов самим художником является одной из главных сцен уходящего вдаль торгового пространства. По сути, перед нами коллективный портрет уже достаточно обнищавшего московского и подмосковного люда конца 1990-х. Каждое действующее лицо - индивидуально, так как композиция строится на основе натурных зарисовок.

Над всем этим круговоротом купли-продажи на фоне чистого неба с белыми перистыми облачками мощно доминируют колонны наземной части метростанции, столб с громкоговорителями и почти белое из-за состояния световоздушной среды высотное здание МГУ. Сомнений нет, всё это происходит в столице нашей Родины Москве и символы государственности «Страны 
Советов» стоят на своих местах непоколебимо. Народ, правда, излишне сосредоточен, но зато ситуацию немного скрашивают привезённые из Турции яркие цвета пляжных зонтов, используемых для защиты от скоротечных, но очень злых дождей (рис. 1).

Почти квадратный офорт «У метро «Комсомольская» - попытка запечатлеть жизнь Москвы у «трёх вокзалов». Единый, никогда не спящий комплекс из метростанций и трёх крупнейших железнодорожных вокзалов страны живёт своей особой «чемоданно-пересадочной» жизнью. Пассажиры, уставшие от спанья на жёстких койках вагонов или сидения на деревянных скамьях пригородных электричек, встречаются армией лоточников и лоточниц разных возрастов, продающих сигареты, «куры горячие», самошвейные хозяйственные сумки с надписью «Москва - 850 лет», краковскую колбасу и даже что-то горячительное. Гости Москвы с трудом продираются через плотную толпу и ныряют в глубину метро. Циклопический наземный вестибюль метростанции «Комсомольская» с огромными капителями где-то наверху, призванный, видимо, поразить приезжего из глубинки, как правило, остаётся незамеченным. Свой вклад к ощущениям встречи со столицей вносит и объёмный багаж в руках путешественников, перенося основную часть мыслей из головы к ручкам чемоданов, сумок и тележек (рис. 2).

Как и в композиции «У метро «Университет», Дергилёва использует приём противопоставления величественной архитектуры, олицетворяющей незыблемость державы, и суетности обыденного существования обывателя. Но если первая работа - символ Москвы торгующей, то вторая Москвы торгующей и путешествующей. Первая работа построена как горизонтальное эпическое полотно - людское суетное море под огромным куполом неба, второе - как фрагмент бесконечного потока людей. Поток выливается за пределы картинной плоскости, и художник «выхватил» только один из характерных его участков. Мы знаем, что столпотворение продолжается как на перронах у электричек, так и в «чреве» метро.

Окраинные станции метрополитена представлены в серии композициями с вестибюлями метро «Проспект Вернадского» и «Юго-Западная». Метро «Проспект Вернадского» изображено в начале тёплой осени в воскресенье. Ситуация типична для новых районов «бетонной» Москвы: неспеш- но выходящие из-под земли жители многоэтажек, троллейбусные растяжки на столбах, автобусы, реклама мехов и дублёнок, «кучкующиеся» группы мужчин непонятной национальности, торгующие свежим хлебом, яблоками, персиками и арбузами женщины и собаки, возлежащие на тёплом асфальте. Играющие с воздушными шариками дети, с модной тогда надписью «Макдональдс» и логотипом «М», похожим на метро-символику.

Прямоугольная стекляшка наземной части метро «Юго-Западная» противопоставлена автором плотному замесу движущихся людей. В те годы у станции уже бойко торговал рынок, и стояли маршрутки, уходящие в область, но современного ошеломляющего круговорота людей и транспорта ещё не было. Автор, проживая на расстоянии одной остановки от «Юго-Западной», часто посещала грязноватый, но с довольно качественными продуктами торговый развал. Он был дешевле, чем у метро «Университет» из-за своего расположения и наличия значительного процента колхозников. Место явно шумноватое, но оно нравилось жителям, и подруги, живущие в этом районе, попросили Дергилёву запечатлеть ситуацию в летнем и зимнем состоянии, правда, подруги эти - иностранки.

В летнем варианте площадка у метро подана как транспортная развязка районного масштаба - периферийный центр города. Это выражено в кольцевой компоновке фигур у ступенек станции и сложном социальном составе действующих лиц. Центральную часть композиции занимает группа трудоспособного населения, движущегося ко входу в метро. Их фигуры сделаны несколько крупнее и энергичнее. Фоном для них служат плотные ряды пенсионеров, подторговывающих растительно-цветочной продукцией со своих огородов. Кто-то звонит по большого размера сотовому телефону, кто-то жуёт на ходу пирожок или тащит тяжеленный портфель. Зимний вариант более пустынен, и уже можно разглядеть автобусные остановки, оклеенные народом листочками с текстами с различными предложениями. На фоне синеватых синтепоновых курток мужчин хорошо читаются фигуры заботливых женщин в красивых пальто и шубах с хозяйственными сумками в руках. Им хочется быть красивыми и, одновременно, кормить семью. Холодно, и люди стараются не задерживаться.

Подземные интерьеры метро запечатлены в офортах со станциями: «Парк Культуры», 
«Белорусская», «Арбатская», «Бауманская», «Динамо», «Площадь Революции», «Курская» (рис. 3, 4). Пассажиры под землёй предельно погружены в себя и отрешены от среды. Они одиноки среди толпы. Кое-кто с переменным успехом силится читать на ходу или дивиться воробью, невесть как попавшему под землю и севшему на голову скульптуре, но все они - часть бесконечного потока в огромных людских путепроводах. Дети, старики, старухи, цветущие молодые женщины и крепкие мужчины движутся в мареве искусственного света в шубах, пальто, куртках, странных вязаных беретах и одетых как на мужчин, так и женщин шапках-ушанках.

По офортам 1980-х годов можно составить внешний облик советского человека периода «позднего социализма». В руках мужчин «за сорок» встречаются сумки-»авоськи» в виде рыболовной сетки, в которых хорошо просматривается вся нехитрая снедь и свежая газета. А что? Советскому человеку нечего скрывать, хотя и гордиться тоже особенно нечем...

Когда едешь в вагоне метро без давки, то у тебя есть всего три развлечения: дремать, читать и листать прессу или ненавязчиво разглядывать попутчиков. Разглядывают все, так как москвичи очень любопытны по своей природе. Этот процесс разглядывания интуитивно включается, как только подходишь к листам с изображениями схем метро. В офортах нет ни одной сцены в вагоне, но ты непрерывно сканируешь композицию, что-то выискивая напротив себя. В сотнях изображённых людей знакомые Дергилёвой находят своих родственников и даже себя, так как автор часто вставляет изученные образы в привычную им обстановку. Как правило, подруги и друзья изображаются на втором плане или в повороте. Их трудно узнать, так как это, конечно, не портреты, а типизированные образы, но узнают со словами: «А у меня такой старой шапочки нет!» Шапочка-то есть, но трудно признаться, что она, при взгляде со стороны, смотрится мило, но нелепо.

Особая тема в офортных композициях - пластические взаимосвязи скульптурного убранства и живых движущихся людей. Со времён постройки центральных станций-дворцов наши люди изменились. Новые искусственные и синтетические материалы с модифицированной вискозой или «лайкрой» активно повлияли на пластику одетой фигуры, походку и даже манеру поведения. В 1980-е эта одежда из синтетики ещё только входила в жизнь, но в двухтысячные достижения европейских и американских домов мод окончательно прижились в России. Однако по-прежнему в вагонах можно увидеть молодых людей из провинции в трикотажных головных уборах отечественной вязки с надписью «adidas» или «forward», по-прежнему рядом со скульптурами рабочих в кепках с жесткими козырьками кого-то ожидают, поставив сумки у ног героя труда, полноватые женщины. В офорте «На станции «Курская» из толпы выделено изображение милиционера. Несмотря на центральное место его расположения, он также погружён в свои «милиционерские» мысли. Только скованность фигуры выдаёт его «рабочее состояние», позволяющее смотреть на пассажиров сквозь щёлочки глаз. «Рог изобилия» в виде колонны накрывает всё действо гигантским зонтиком. Довоенная и послевоенная скульптура в метро живёт своей тревожной жизнью. Бетонные изваяния партизан с автоматами и матросов с пистолетами встречают и провожают москвичей и гостей столицы, а танцующие пары в лёгкой одежде на горельефах невозмутимо кружатся среди взъерошенных московской непогодой пассажиров. «Каменные гости» и их бронзовые «друзья» уже давно не смущают москвичей, и они им уже нравятся... Даже такие фантастические по количеству скульптур станции, как «Площадь Революции» входят в контекст культуры времени. Скульптуре созвучен архитектурный экстерьерный орнамент, проникший в интерьеры метро. Его мощные барочно-ампирные завитки воспринимаются как элементы быта живших когда-то великанов. Они несоразмерны выскочившим из метро-вагонов слегка помятым пассажирам ни формой, ни патетикой содержания. Имеющийся зрительный конфликт автор отражает в офорте «Метро Арбатская», изображая спешащих москвичей на фоне огромной белой горельефной рамы, в которой ещё в 1950-е годы красовалось изображение И. В. Сталина. Кажется, что свечение, идущее от центра замазанного штукатуркой изображения, заставляет съёживаться и ускорять шаг даже потомков бывшего в его власти народа.

В Москве всегда много провинциальности и наивности, несмотря на стремление к утончённости. Московское купечество бросало в крайности, что проявилось в эклектичности архитектуры. Та же участь постигла архитектуру переехавших из Питера в Москву большевиков, и метро этому 
подтверждение. Холодный «хай-тек» так же плохо приживается в московской подземке и требует привязки к характеру москвича. Скорее всего, Москва традиционно тяготеет к эклектике и пестрота ощущений её не пугает. Разные культуры и времена соединились в ней, и будут соединяться ростками новой ещё не до конца сформировавшейся жизни. Нелепое и несуразное, художественное и высокое, сливаясь и перемешиваясь, создают питательную почву для «неизвестного завтра».

Говорят, что московское метро нужно любить. Возможно. Ведь если любишь, то прощаешь многие изначальные и благоприобретенные недостатки и восхищаешься несомненными достоинствами. Метро - отражение нас самих, беспокойных и наивных, консервативных и странно радикальных, утончённых и аляповатых.

Все композиции, посвящённые метро, отрисованы Дергилёвой на цинковых пластинах непосредственно с натуры. Сказать, что рисование в метро требует огромного напряжения - почти ничего не сказать. Работе художника там просто нет места ни физически, ни психологически. Ме- тро последних десятилетий ушедшего века можно сравнить с перевозбуждённой нервной системой человека на грани срыва. Как там можно было рисовать, представить невозможно. Но это было. Анализ композиций показывает нам, что они задуманы и исполнены натурно. Выхваченные взглядом фрагментарные ракурсные участки подземного круговорота, многофактурные сцены у входа в метро - созданы стоя среди ошалевших от тягот жизни москвичей.

Изучая сделанную Дергилёвой офортную «подземную» серию из двух десятков разноразмерных композиций, можно сказать, что именно в них наиболее ярко выявился талант рисовальщика и «сюжетника». Множество изображённых в движении людей, мастерски отрисованных в сложные композиционные построения горизонтального, диагонального, кольцевого типов или их сочетаний, создают тот контекст переходного времени, который читается зрителем как глубоко содержательный, наполненный тревожными ощущениями текст. Этого не сделать по прошествии времени, это создаётся только внутри событий.

\section{БИБЛИОГРАФИЯ}

1. Бесчастнов Н. П. Нарисованная Москва Алёны Дергилёвой. Образы города // Архитектура, строительство, дизайн. - № 01/02. - 2020. - С. 102-107.

2. Дергилёва А. И., Митрофанов А. Г. Москва: Домашний альбом. - М.: Москва, которой нет, 2011. - 168 c.

3. Дергилёва А.И. Нарисованная Москва.- М.: Контакт-культура, 2017.- 264 с.

4. Balik, Gökhan, Lökçe, Deniz Balık. 2019. «On the Relationship of Landscape and Painting», AM Journal of Art and Media Studies, no.19, pp. 29-44 DOI: http:// dx.doi.org/10.25038/am.v0i19.305

5. Häyrynen, Maunu. 2014.»Lost Landscapes: Degraded Landscape as Anti-Landscape.», The Anti-Landscape, edited by David E. Nye and Sarah S. Elkind, pp. 149158. Leiden: Rodopi

6. Somhegyi, Z. 2019. «Pages and Full Stops: On the Aesthetic Relation between Books and Art», AM Journal of Art and Media Studie, No. 19, pp. 69-75. DOI: http:// dx.doi.org/10.250 
Nikita P. Lushchenkov

Postgraduate student of the Faculty of Art History

The Ilya Glazunov Russian Academy of Painting, Sculpture and Architecture e-mail:lushenkov.keith@yandex.ru

Russia, Moscow

ORCID 0000-0002-3315-6621

\section{HISTORY AND ART PIECES IN THE FILM "ALEXANDER NEVSKY" BY SERGEI EISENSTEIN}

Summary: The heritage of Sergei Mikhailovich Eisenstein nowadays is a serious subject for scientific research. In the last two decades the original articles and books of the great director "cleared" of Soviet censorship and abbreviations, have been published, and the study of existing and lost cinematic works of the master continues nowadays.

The film "Alexander Nevsky" (1938) was shot under the conditions of the already existing order for the arrest of Eisenstein, but the final approval of the film by Stalin actually suspended the prosecution of the director.

The problem of including images of Russian and world painting in the film frame in Eisenstein's works is practically not studied - his films (unlike, for example, the films of Andrei Tarkovsky) can hardly be regarded as those ones with direct quotations of certain works of pictorial art. Despite this fact, Eisenstein, as it will be shown in this article, repeatedly resorted to various methods of including in his films certain artistic images borrowed from very specific paintings. It is "Alexander Nevsky" and Ei-

By the spring of 1937, the time of the beginning of Stalin's "Great Terror", an order for the arrest of Eisenstein had already been prepared. Shortly before that, the projects of his films "MMM" and "Moscow" were rejected, and the film "Bezhin Meadow" was withdrawn from production. The first persons of the Soviet Union - the People's Commissar of Heavy Industry L. Kaganovich, the People's Commissar of Defense K. Voroshilov, the chairman of the SNK V. Molotov signed the document which imlpied deathful sanctions for the director. Molotov, however, later crossed out his signature for some reason that we still don't know.

Eisenstein, well aware of the danger hanging over him, decided to take the last step, dropping the petition to Stalin in the box for messages to the leader on Red Square. In that letter, he assured that he senstein's last film "Ivan the Terrible" that are examples of cinematic works where such intersections of frame structures with the pieces of world art become especially noticeable when carefully examined.

"Alexander Nevsky" is not only a "defense film". The attempt to analyze this film from this point of view is a way to miss the entire historical, symbolic, and philosophical subtext of the film. "Alexander Nevsky" is a kind of an epic film, shot in the format of a fresco-film and containing numerous allusions not only to the events of Biblical and Russian history and hagiographic literature, but also to works of pictorial art. In the frames of the film (not so clearly at the first glance), the world of paintings by Vasily Vereshchagin and Nicholas Roerich, illustrations to the fairy tales of Ivan Bilibin comes to life again. The frame image also shows clear intersections with paintings by Caravaggio and El Greco - one of Eisenstein's the most valued masters of fine art.

Keywords: Sergey Eisenstein, painting, frame, Alexander Nevsky, allusion, film, images, script, fine art

could still prove his worth as a director, but he needed trust and support.

It is not known for certain whether the letter came directly to Stalin, but soon the director was summoned to the Kremlin, where he was given, in the words of the largest researcher of Eisenstein's heritage, Naum Kleiman, a last attempt "to shot the right film" ${ }^{1}$. The country's leadership suggested that Eisenstein make a film on the theme of Russian history, choosing between two pre-purchased scripts. One of them was about the era of the Time of Troubles and the liberation war of Russia from the Polish-Swedish invaders; the other - about the era of Alexander Nevsky and his struggle against the German Crusader knights. For Eisenstein, according

1. https://arzamas.academy/materials/348 [accessed: $25 \mathrm{Apr}$ 2021]. 


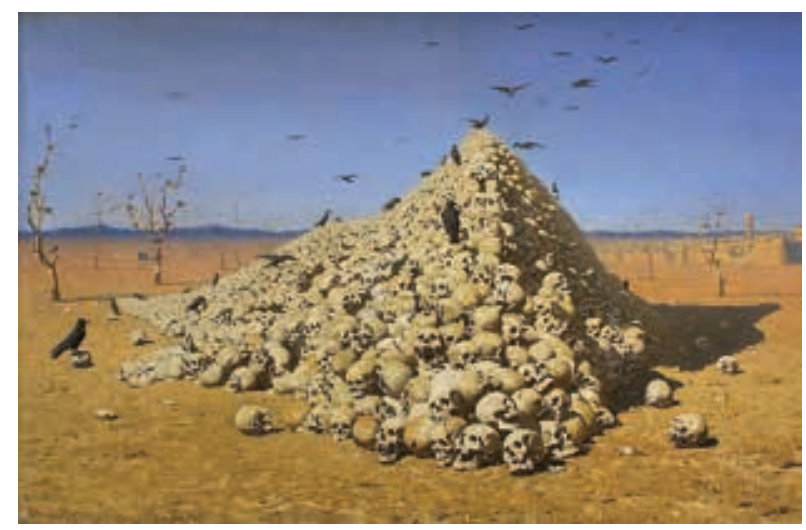

IIl. 1. Vasily Vereshchagin. "The Apotheosis of War", 1871

to the memoirs of Mikhail Romm, who spoke with him before shooting of the film, the choice was obvious: the epoch of the XIII century, in contrast to the XVII, was seen as distant and poorly studied, which in turn gave great scope for the author's idea and its subsequent implementation.

Eisenstein conceived Alexander Nevsky not as a biographical, documentary-historical or defensical (as the authorities assumed), but as a hagiographic film about the great Russian prince. Naturally, Eisenstein's idea here went further: the hero of Nikolai Cherkasov appears precisely in the key, fateful moments of the historical events depicted - we don't see him a lot during watching the film. Eisenstein made a film not only specifically about Nevsky, but about the entire Russian nation and the historical era of the middle of the XIII century. This is evidenced not only by the way the film is built and mounted, but also by the director's notes ("Bones. Skulls. Scorched fields. Charred wreckage of human habitation. People taken into slavery. Ruined cities. Violated human dignity. This is the terrible picture of the first decades of the XIII century in Russia" ${ }^{2}$ ), and the fact that the film, according to the original plan, was to be called "Rus".

In this article, the author will focus on the pictorial and figurative structure of the film, which find meaningful, compositional and stylistic points of contact with images and works of Russian and European fine art.

Eisenstein's passion, first, for Mexican fresco painting (the works of Diego Rivera and Jose Orozco) and, secondly, his excellent knowledge of works of Russian and European art, are the most important factors that influenced the logic and features of the construction of the film's shots. The hero of Nikolai

2. Eisenstein S. M. Selected works in 6 t. M.: Iskusstvo, 1964. p. 165.

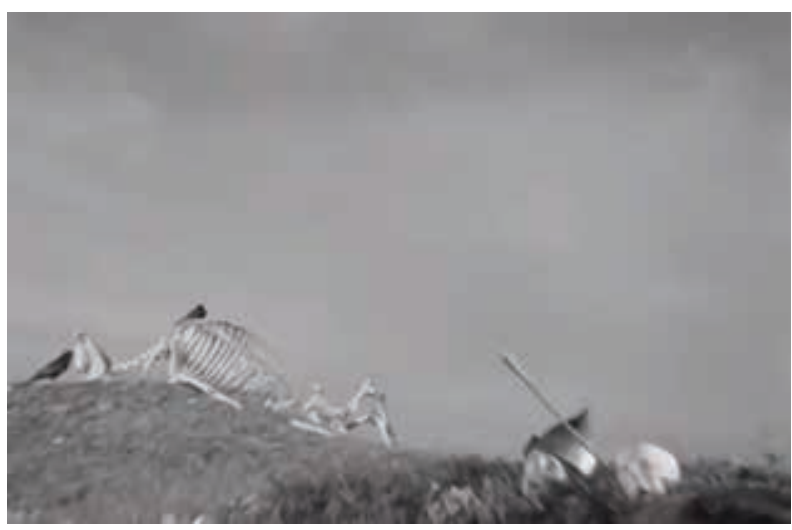

Ill. 2. Shot from the film "Alexander Nevsky", 1938

Cherkasov often appears in the film in a three-quarter turn, and the viewer sees, as the largest expert on the work of Sergei Eisenstein, Naum Kleiman claimed, only " 25 percent of the face" ${ }^{3}$ of Cherkasov. It is these " 25 percent" that give the hero a particularly solemn and timeless appearance. Cherkasov's face is recalling the frescoes of saints on the pillars of Orthodox churches.

"Alexander Nevsky" was really conceived by the author in the format of a fresco-film - the picture begins with static, unfolding one after another (similar to how the cycle of frescoes is considered) landscape scenes, continuing with the same essentially frescoed shots of fishermen on Pleshcheyev Lake. The" ritualism "of these frames, as noted by Naum Kleiman, will later be revealed in the work of Sergei Parajanov (starting with "The Color of Pomegranate"), but, in our opinion, it will manifest itself in Parajanov's earlier film - in "Shadows of Forgotten Ancestors".

The very first shots that begin "Alexander Nevsky" depict deserted fields and hills - the boundless expanses of Russian lands, literally strewn with the bones and skulls of fallen soldiers. This episode is a memory of the recent Tatar-Mongol invasion. "The traces of the brutal battles were still visible all over the country" - this phrase, flashing on the dark screen at the beginning of Sergei Prokofiev's cantata, precedes the film.

In its composition, content, and epic and tragic nature, the first shots of "Alexander Nevsky" seem incredibly close to the works of the main Russian battle artist Vasily Vereshchagin. In the first frame of the film, in the foreground, Eisenstein captures a valley flooded with sunlight, all over the space of

3. Kleiman N.I. Alexander Nevsky.[Electronic resource] URL: https://arzamas.academy/materials/348 [accessed: 27 Apr. 2021]. 
which are scattered armor, helmets, skulls and bones of the dead. Most of them are given by the director in large details. The ground is uneven: the defenders of the Russian land are buried under it. In the background, dark hills loom like a low mountain range. They seem to limit the space of the frame, to close it. The same desolate and lifeless landscape, illuminated by the hot sun, can be observed in one of Vereshchagin's small-format works "The Ruins of Chuguchak" (1869-1870) from the collection of the State Tretyakov Gallery. "The Ruins of Chuguchak" is a work that the connoisseur of world painting Eisenstein, without any doubt, could repeatedly observe with his own eyes.

Vereshchagin's work depicts the vast expanse of the sun-scorched steppe, with the skulls of fallen soldiers scattered everywhere and especially clearly rendered in the foreground. Behind the ruins of an ancient Chinese fortress, the space of the picture, like the frame of Eisenstein, is enclosed by a dark blue mountain range.

Watching these scenes it is also impossible not to recall a famous painting "Apotheosis of War" (1871), also from the collection of the Tretyakov Gallery. In the third frame from the beginning of the film, the skulls of the fallen soldiers are shown in close-up, and in the next one, a more general landscape plan, is given with a human skeleton and black ravens in the left part of the frame. The frame of Eisenstein and the canvas of Vereshchagin are distinguished by common compositional features -a static inviolability of the image, a conventional landscape, a transmission by including the theme of death in the image of skulls and bones, the presence of black ravensscavengers near the slain warriors, etc.

The subsequent scene, which takes place on the shores of Lake Pleshcheyev, from a historical point of view, clearly refers to the events of the gospel times. According to the researcher Bernd Uhlenburch, there are exactly twelve ${ }^{4}$ fishermen pulling a net with fish in several consecutive frames. The number of fishermen is according to the number of disciples of Christ. The hero of Nikolai Cherkasov, is called to save Novgorod and the entire Russian land, is also represented by a fisherman. This image contains a reference to the story of Simon,

4. Uhlenbruch. B. Myth as sedition. Guesses about the "Alexander Nevsky". M:, Kinovedcheskie zapiski, No. 53, 2001. [Electronic resource]

URL: http://www.kinozapiski.ru/ru/article/sendvalues/760/ [accessed 24 Apr. 2021]. the future apostle Peter, who until the moment of his calling by Christ was also a fisherman.

First frames of the scene on Pleshcheyev Lake, find out visual and compositional similarity with the early works of Nicholas Roerich from the series "The Beginning of Russia. Slavs". The second frame of the scene on Pleshcheyev Lake, depicting the shore and the rooks under construction (after which young people in white robes "enter" the frame, carrying bars) finds obvious points of intersection with Roerich's work "Building rooks" (1903, the State Museum of the East) - - the white robes of the builders of the rooks, massive bars piled near the still unfinished ships, etc.

The scene with the execution of the Pskov voivode Pasha again imposes a historical and cultural parallel with the theme of the crucifixion, but, unlike the subsequent brutal scene of the Germans throwing babies into the fire (clearly going back to King Herod and the plot of the Beating of babies and, by the way, anticipating the horror of the Holocaust), is also the basis for an art criticism analysis. The almost perfect profile of Pasha, performed by Vasily Novikov, with gray hair and a thick whitish beard, resembles the iconographic image of the Apostle Peter. The black cross that appears behind the voivode, hanging over him, seems to symbolize the cross on which the apostle was crucified. The strict and beautiful face of Pavshi, with its regular features, wise and severe eyes, slightly sunken cheeks, is reminiscent of the images of the apostles and saints in the works of Caravaggio, and reveals a stylistic intersection with the portrait image of Peter from the altarpiece "The Crucifixion of St. Peter" (1601, Santa Maria del Popolo, Rome).

Such intersections are not a scientific interpretation: Eisenstein's fascination with the work of the great Italian began many years before the shooting of "Alexander Nevsky". The very theme of the intersection of Eisenstein's work with the paintings of Caravaggio was previously traced in the scientific literature. Thus, the researcher Umberto Barbaro in the work "Slavery and the greatness of cinema" (1962) draws parallels of screams in Eisenstein's early works ("Battleship Potemkin") with screams in the works of Caravaggio (for example, the work "Medusa", 1597, Uffizi Gallery, Florence), while Eisenstein himself devoted a small passage to the painter in his memoirs: "Caravaggio (striking angles of placing figures not "in the field of the frame", then is 


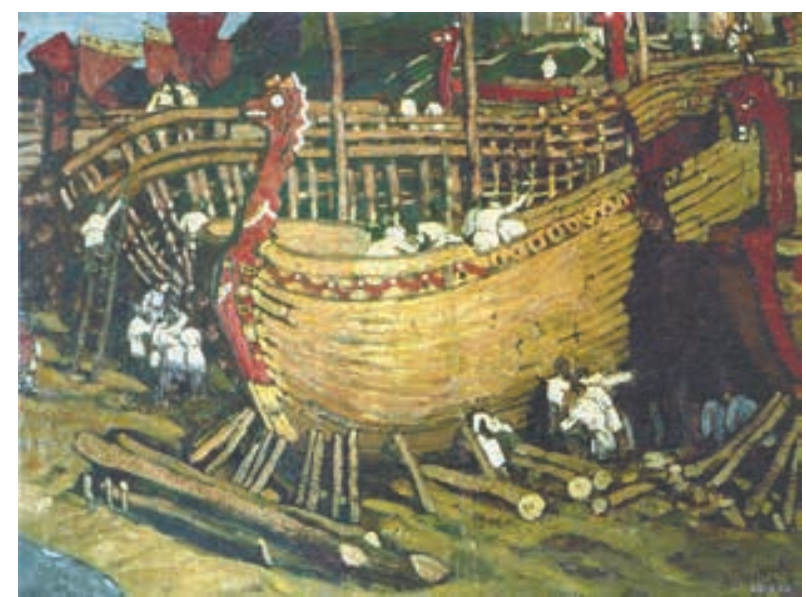

IIl. 3. 2. Nikolai Roerich, Ships' construction, 1903

in the contour of the frame, and "in relation to the plane of the frame").

Eisenstein's well-known interest in the work of El Greco (Eisenstein created the essay " El Greco and the Cinema"), according to the Brazilian film theorist and critic Jose Carlos Avellar ${ }^{5}$, is found in the scene preceding the action of the Battle on the Ice almost abstract landscapes depicting a thin strip of the surface of Chudskoe Lake and overhanging the site of the future battle with storm clouds similar to those presented in the famous canvas "View of Toledo" " Toledo in a Thunderstorm", "Storm over Toledo", 1596-1600, Metropolitan Museum of Art, New York).

Turning to the topic of Russian art, we note that the clouds over Chudskoe Lake in Eisenstein's movie reveal more object artistic parallels with the works of Arkhip Kuindzhi (in particular, "Ladoga Lake", 1873, State Russian Museum), who was an undoubted master of the celestial landscape and the light-air environment - such an important compositional element for the overall structure of "Alexander Nevsky".

In the work "Ladoga Lake", as well as in the shots with the view of the sky over Chudskoe Lake in Eisenstein's film, the light-air environment prevails over the earth's space - low cumulus pre-storm clouds foreshadow an imminent thunderstorm, just as the overhanging clouds in the film symbolize a close fateful battle.

Another important source for revealing the artistic diversity of pictorial images that found a response in "Alexander Nevsky" is works of Ivan Bilibin. For example, in the illustration "Andrey-the shoot-

5. Avellar J.K. The Horse of Three Heads. Eisenstein for the XXI century: a collection of articles. Moscow:, Garage, 2020.

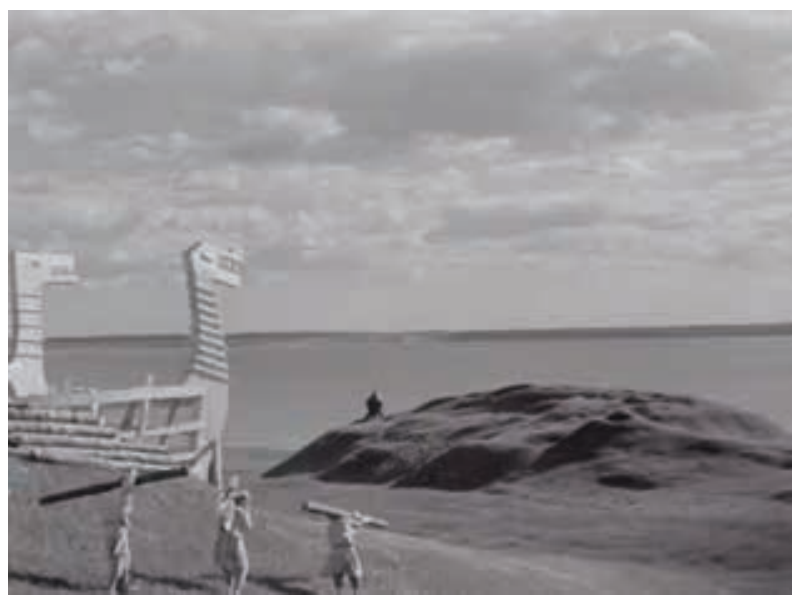

Ill. 4. Shot from the film "Alexander Nevsky", 1938

er and the Strelchikha" created in 1900 to the fairy tale "Go there - I don't know where", the image of the fairy-tale character incredibly intersects with the Eisenstein's image of the Novgorod voivode Gavrilo Oleksich performed by Andrey Abrikosov. The winter landscapes of Bilibin ("The stream"," Winter") find common features with the landscape scenes of the winter forest, in the frames preceding the battle.

Considering Eisenstein's films from an art criticism point of view and analyzing the inclusion of certain references to paintings in the film, it is worth remembering that the director never pursued the goal of literally quoting works of art in his films and did not strive for a clear construction of frames based on direct copying of picturesque images. In the article "Fine Art and Cinema of Sergei Eisenstein" 6 , Naum Kleiman wrote about the actual absence of direct quotations from paintings in the master's films. The true art of cinema for Eisenstein, of course, is not limited to copying and has a timeless, eternal character. "Alexander Nevsky" was not and could not be removed only as a memory of the former glory of Russia. Projecting through historical events the phenomena of the present and through painting images, the situation of reality - are one of the most important ideas of Eisenstein.

"Alexander Nevsky" is still sometimes perceived by many viewers as an exemplary, but still purely "defense film". But Eisenstein, in the surprisingly accurate expression of Naum Kleiman, "used in this film the whole cultural reserve that was carefully erased from our history and mind" 7 .

6. Kleiman N.I. Fine Art and Cinema of Sergei Eisenstein. Moscow: Russian Art, No. 2, 2019. pp. 46-55.

7. https://arzamas.academy/materials/348 [accessed: 27 Apr. 2021]. 


\section{REFERENCES}

1. The Bible. Books of the Holy Scripture of the Old and New Testament. Moscow: Edition of the Moscow Patriarchate, 1976.

2. Universal History of Art in 6 Vol. M: Iskusstvo, 1953.

3. Ilyina, T. V. 2000. History of Art. Russian art, Moscow, High Sch.

4. Kleiman, N. I. 2019. Fine art and cinema of Sergei Eisenstein. Moscow: Russian Art, No. 2, pp. 46-55.

5. Kleiman, N.I. Kleiman N.I. Alexander Nevsky.[Electronic resource]

6. URL: https://arzamas.academy/materials/348

7. Lebedev, A. K. 1958. V.V. Vereshchagin. Life and Creativity. Moscow: Iskusstvo

8. Uhlenbruch, B. 2001. "Myth as sedition. Guesses about the "Alexander Nevsky"", Kinovedcheskie zapiski, no. 53. [Electronic resource]

9. URL: http://www.kinozapiski.ru/ru/article/sendvalues/760/

10. Shklovsky, V. B. 1923. Literature and cinema. Berlin, 1.

11. Eisenstein S. M. Selected works in 6 Volumes. M.: Art, 1964.

12. Eisenstein S. M. Memoirs in 2 volumes. M.: Editorial Office of the newspaper "Trud", Museum of Cinema, 1997. (Live Classics)
13. Eisenstein S. M. Eisenstein \Eisenstein. Drawings / Dessins / Drawings. - Moscow: Iskusstvo, 1961.

14. Eisenstein S.\ Eisenstein. / Dessins / Drawings. - Moscow: Iskusstvo,1961.

15. Gallez, DW. 1978. "Prokofiev-Eisenstein collaboration "Nevsky" and "Ivan" revisited", Cinema Journal, vol. 17 (2), 13-35. DOI: 10.2307/1225488

16. Polan, DB. 1977. "Eisenstein as theorist + Eisenstein Sergey", Cinema Journal, vol. 17 (1), pp. 14-29. DOI: 10.2307/1225467

17. Prince, S. 1992. "The Kuleshov-Effect + Film editing and Russian film history - Recreating the classic experiment", Cinema Journal, vol. 31 (2), pp. 59-75. DOI: $10.2307 / 1225144$

18. Radunovich, D. 2017. "The Shifting Protocols of the Visible: The Becoming of Sergei Eisenstein's The Battleship Potemkin", Film History, vol. 29 (2), pp. 66-90. DOI: 10.2979/filmhistory.29.2.03

19. Rees, E. 2020. “Design, Creativity, and Technology: The Khudozhnik in Russian Cinema of the Silent Era", Film History, vol. 32 (4), pp. 60-90. DOI: 10.2979/filmhistory.32.4.03 


\section{ИСТОРИЯ И ЖИВОПИСНЫЙ ОБРАЗ В ФИЛЬМЕ «АЛЕКСАНДР НЕВСКИЙ» СЕРГЕЯ ЭЙЗЕНШТЕЙНА}

Аннотация: Наследие Сергея Михайловича Эйзенштейна в настоящее время во многом открывается заново, становясь предметом исследования ведущих теоретиков кино, кинокритиков и искусствоведов. Широкий интерес к творчеству Эйзенштейна вызван прежде всего тем фактом, что в последние два десятилетия в свет впервые вышли оригинальные статьи и книги великого режиссера, «очищенные» от советской цензуры и сокращений. В последние годы также продолжается детальное исследование существующих и утраченных кинематографических работ мастера.

Фильм «Александр Невский» (1938 г.) снимался в условиях уже существовавшего распоряжения об аресте Эйзенштейна, однако итоговое одобрение Сталиным фильма (пусть и не в том варианте, который планировал сам автор) фактически приостановило преследование режиссера.

Тема включения в кинокадр образов отечественной и мировой живописи в работах Эйзенштейна практически не исследована, - в его картинах, в отличие, например, от фильмов Андрея Тарковского, действительно нельзя усмотреть прямых цитирований тех или иных произведений живописного искусства. Несмотря на этот факт, Эйзенштейн, как будет показано в настоящей статье, многократно прибегал к различным приемам включения в свои работы тех или иных худо-

На момент весны 1937 года, времени начала сталинского «Большого террора», был подготовлен приказ об аресте Эйзенштейна. Незадолго до этого проекты его картин «МММ» и «Москва» оказались отклонены, а находившийся в проектировании фильм «Бежин луг» внезапно был снят с производства. Подписи под тем, так и не ставшим роковым документом, поставили первые лица государства - нарком тяжёлой промышленности Л. Каганович, нарком обороны К. Ворошилов, председатель СНК В. Молотов. Последний, однако, свою подпись по какой-то причине позже зачеркнул. жественных образов, заимствованных из конкретных живописных произведений. Именно «Александр Невский» и последний фильм Эйзенштейна «Иван Грозный» представляют собой примеры кинематографических работ, где подобные пересечения кадровых построений с образами живописи при внимательном их рассмотрении становятся особенно заметными.

«Александр Невский» - это далеко не только лишь «оборонный фильм». Попытка рассмотреть эту работу Эйзенштейна с подобной, узкой точки зрения, означала бы упустить весь исторический, символический и философский подтекст фильма. «Александр Невский» - это своего рода фильм-эпопея, снятый в формате кинофрески и заключающий в себе многочисленные аллюзии не только на события библейской и русской истории и житийной литературы, но и на произведения живописного искусства. В кадрах фильма (на первый взгляд не столь явно) вновь оживает мир полотен Василия Верещагина и Николая Рериха, иллюстраций к сказкам Ивана Билибина; в кадре присутствуют пересечения с картинами Караваджо и Эль Греко - наиболее ценимых Эйзенштейном мастеров мирового искусства.

Ключевые слова: Сергей Эйзенштейн, живопись, кадр, Александр Невский, аллюзия, фильм, образы, сценарий, изобразительное искусство

Эйзенштейн, прекрасно осознавая нависшую над ним опасность, решился на последний шаг, опустив прошение к Сталину в небезызвестный ящик для посланий вождю на Красной площади. В том письме он уверял, что ещё может доказать свою состоятельность как режиссер, однако для этого ему необходимы доверие и поддержка.

Достоверно неизвестно, попало ли то письмо непосредственно к Сталину, однако вскоре режиссера вызвали в Кремль, где ему была предоставлена, по выражению крупнейшего исследователя творчества Эйзенштейна Наума 
Клеймана, последняя попытка «поставить правильный фильм» ${ }^{1}$. Руководство страны предложило Эйзенштейну снять фильм на тему русской истории, выбрав между двумя заранее купленными сценариями. Один из них рассказывал об эпохе Смутного времени и освободительной войне России от польско-шведских интервентов; другой - об эпохе Александра Невского и его борьбой против немецких рыцарей-крестоносцев. Для Эйзенштейна, по воспоминаниям беседовавшего с ним накануне съемок фильма Михаила Ромма 2, выбор был очевиден: эпоха XIII века, в отличие от XVII, виделась далёкой и малоизученной, что в свою очередь давало большой простор для авторского замысла и его последующего воплощения.

«Александр Невский» задумывался Эйзенштейном не как биографический, документальноисторический и уж тем более просто оборонный, но как агиографический фильм, - своего рода фильм-житие великого русского князя. Естественно, что замысел Эйзенштейна и здесь уходил дальше даже фильма-жития, - герой Николая Черкасова отнюдь не возникает перед зрителем в каждом следующем кадре, но появляется именно в ключевые, судьбоносные моменты изображаемых исторических событий. Важно отметить и то, что Эйзенштейн снимал фильм не только лишь конкретно о Невском, но обо всём русском народе и исторической эпохе середины XIII века. Об этом свидетельствует не только то, как построен и смонтирован фильм, но и записи режиссёра $^{3}$, и тот факт, что фильм, по первоначальному замыслу, должен был называться «Русь».

Предметом настоящей статьи станет анализ живописного и образного строя фильма, находящего содержательные, композиционные и стилистические точки соприкосновения с произведениями русского и европейского изобразительного искусства.

Увлечение Эйзенштейна, во-первых, фресковой живописью в Мексике (Работы Диего Риверы и Хосе Ороско) и, во-вторых, прекрасное знание произведений русского и мирового искусства, -

1. https://arzamas.academy/materials/348 [дата обращения: 25 aпр. 2021].

2. Там же

3. («Кости. Черепа. Выжженные поля. Обгорелые обломки человеческого жилья. Люди, уведённые в рабство. Разорённые города. Попранное человеческое достоинство. Такой встаёт перед нами страшная картина первых десятилетий XIII века в России»). Эйзенштейн С. М. Избранные произведения в 6 Т. М.: Искусство, 1964. С. 165. важнейшие факторы, повлиявшие на саму логику и особенности построения кадров фильма. Герой Николая Черкасова часто возникает в фильме в трёхчетвертном повороте, и зритель видит, по выражению Наума Клеймана, лишь «25 процентов лица» 4 Черкасова. Именно эти «25 процентов» придают герою особенно торжественный, вневременной облик, напоминая о фресковых изображениях святых на столбах православных храмов.

«Александр Невский» действительно мыслился автором в формате кинофрески - картина начинается со статичных, разворачивающихся друг за другом (подобно тому, как идёт рассмотрение цикла фресок) пейзажных сцен, продолжающихся такими же фресковыми по своей сути кадрами рыбаков на Плещеевом озере. «Ритуальность» этих кадров, как отмечал Наум Клейман, позже обнаружится в творчестве Сергея Параджанова (начиная с «Цвета граната»), однако, по нашему мнению, проявится у последнего ещё раньше в «Тенях забытых предков».

Самые первые кадры, с которых начинается «Александр Невский», изображают пустынные поля и холмы, - безграничные просторы русских земель, буквально усеянные костьми и черепами погибших воинов, - воспоминание о недавнем татаро-монгольском нашествии. «Следы жестоких сражений ещё виделись по всей стране», - именно эта фраза, вспыхивающая на тёмном экране под начало кантаты Сергея Прокофьева, предваряет фильм.

По своей композиции, содержанию и эпическому и трагическому характеру первые кадры «Александра Невского» кажутся невероятно близкими к работам главного русского художника-баталиста Василия Верещагина. Так, в первом кадре фильма на переднем плане Эйзенштейн запечатлевает залитую солнечным светом долину, по всему пространству которой разбросаны доспехи, шлемы, черепа и кости убитых. Большинство из них даны режиссёром крупно, детально. Земля - неровная, холмистая: под ней погребены защитники русской земли. На дальнем плане тёмным вырисовываются холмы, напоминающие невысокую горную гряду. Они словно ограничивают пространство кадра, замыкают его. Такой же пустынный и безжизненный, освещённый жар-

4. Клейман Н.И. Александр Невский [Электронный ресурс]. URL: https://arzamas.academy/materials/348 [дата обращения: 27 апр. 2021]. 
ким солнцем пейзаж можно наблюдать в одной из малоформатных работ Верещагина «Развалины Чугучака» (1869-1870 гг.) из собрания Государственной Третьяковской галереи. «Развалины Чугучака» - то произведение, которое знаток мировой живописи Эйзенштейн, без всяких сомнений, мог неоднократно наблюдать воочию.

В работе Верещагина изображён бескрайний простор выжженной солнцем степи, с разбросанными повсюду и особенно явственно переданными на первом плане черепами погибших воинов. За развалинами древней китайской крепости пространство картины, как и кадр Эйзенштейна, замкнуто тёмно-синей горной грядой.

Нельзя не уследить в первых кадрах «Александра Невского» и аллюзии на, возможно, самое известное полотно Верещагина «Апофеоз войны» (1871 г.), также из собрания Третьяковской галереи. Так, в третьем от начала фильма кадре крупным планом показаны черепа погибших воинов, а в следующем дан более общий пейзажный план с человеческим скелетом и чёрными воронами в левой части кадра. Кадр Эйзенштейна и полотно Верещагина отличают общие композиционные черты - статичность, незыблемость изображения, несколько условный пейзаж, передача с помощью включения в изображение черепов и костей темы гибели и смерти, присутствие подле убитых воинов чёрных вороновпадальщиков и т.д.

Последующая сцена, разворачивающаяся на берегах Плещеева озера, с исторической точки зрения явно отсылает к событиям евангельских времен. Рыбаков, тянущих сеть с рыбой, по замечанию исследователя Бернда Уленбруха, в нескольких последовательных разноплановых кадрах можно насчитать ровно двенадцать ${ }^{5}$ - по числу учеников Христа. Герой же Николая Черкасова, вскоре призванный на спасение Новгорода и всей русской земли, также представлен рыбаком. Этот образ содержит отсылку на историю Симона, будущего апостола Петра, до момента своего призвания Христом также занимавшегося ловлей рыбы («И сказал Симону Иисус: не бойся; отныне будешь ловить человеков» ${ }^{6}$ ).

С точки зрения искусствоведческого анализа в первых кадрах разворачивающейся сцены на

5. Уленбрух. Б. Миф как крамола. Догадки об «Александре Невском // Киноведческие записки. № 53. М., 2001 [Электронный ресурс]. URL: http://www.kinozapiski.ru/ru/article/ sendvalues/760/ [дата обращения: 24 апр. 2021].

6. Евангелие от Марка. Глава 1, стих 17.
Плещеевом озере нельзя не отметить визуальное и композиционное сходство с ранними работами Николая Рериха из серии «Начало Руси. Славяне». В частности, второй кадр сцены на Плещеевом озере, изображающий берег и строящиеся ладьи (после чего в кадр «входят» молодые люди в белых одеяниях, неся брусья), находит явные точки пересечения с работой Рериха «Строят ладьи» (1903 г., Государственный музей Востока), - белые одеяния строителей ладей, сваленные подле ещё недостроенных кораблей массивные брусья и т.д.

Сцена с казнью псковского воеводы Павши навязывает историко-культурологическую параллель с темой распятия на кресте, но, в отличие от последующей жестокой сцены бросания немцами младенцев в огонь (явно восходящей к царю Ироду и сюжету Избиения младенцев и, к слову, предвосхищающей ужас Холокоста), являет собой почву и для искусствоведческого анализа трактовки образа воеводы. Практически совершенный профиль Павши в исполнении Василия Новикова, с седыми волосами и густой белесой бородой, напоминает принятое в иконографии изображение апостола Петра. Возникающий за спиной воеводы чёрный, нависающий над ним крест, словно символизирует крест, на котором был распят апостол. Строгое и красивое лицо Павши с его правильными чертами, мудрым и суровым взглядом, немного впалыми щеками по своему характеру напоминает образы апостолов и святых в творчестве Караваджо и обнаруживает стилистическое пересечение с портретным изображением Петра из алтарной композиции «Распятие святого Петра» (1601 г., Санта-Мариядель-Пополо, Рим).

Подобные пересечения отнюдь не вольная интерпретация: увлечение Эйзенштейна творчеством великого итальянца началось многими годами прежде начала съёмок «Александра Невского», а сама тема пересечения творчества Эйзенштейна с полотнами Караваджо и ранее прослеживалась в научной литературе. Так, исследователь Умберто Барбаро в работе «Рабство и величие кино» (1962 г.) проводит параллели криков в ранних работах Эйзенштейна («Броненосец Потёмкин») с криками в произведениях Караваджо (например, работа «Медуза», 1597, галерея Уффици, Флоренция), в то время как сам Эйзенштейн посвятил своему восприятию живописца небольшой отрывок в своих мемуарах: «Караваджо (поразительные ракурсы размещения фигур 
не «в поле кадра», то есть в контуре кадра, а «в отношении плоскости кадра»).

Известный интерес Эйзенштейна к творчеству Эль Греко (Эйзенштейн - автор эссе «Эль Греко и кино») также, по мнению бразильского теоретика кинематографа и критика Жозе Карлоса Авеллара ${ }^{7}$, обнаруживается в сцене, предшествующей действию Ледового побоища - почти абстрактные пейзажи с изображением тонкой полоски поверхности Чудского озера и нависающими над местом будущего сражения грозовыми облаками сходны с теми, что представлены в знаменитом полотне «Вид Толедо» («Толедо в грозу», «Буря над Толедо», 1596-1600 гг., Метрополитен музей, Нью-Йорк).

Обращаясь к теме русского искусства, отметим, что облака над Чудским озером у Эйзенштейна обнаруживают художественные параллели скорее не столько с пейзажем Эль Греко, сколько с работами Архипа Куинджи (в частности, «Ладожское озеро», 1873, ГРМ), являвшегося несомненным мастером небесного пейзажа и световоздушной среды - столь важного композиционного элемента для общего строя «Александра Невского». В работе «Ладожское озеро», как и в кадрах с видом неба над Чудским озером у Эйзенштейна, световоздушная среда преобладает над земным пространством, - низкие кучевые предштормовые облака предвещают скорую грозу, точно также, как нависающие облака в фильме символизируют близкое судьбоносное сражение.

Ещё одним важным источником для раскрытия художественного разнообразия живописных образов, нашедших отклик в «Александре Невском», является творчество Ивана Билибина. Например, в иллюстрации «Андрей-стрелок и Стрельчиха» 1900 года к сказке «Поди туда - не знаю куда» образ сказочного персонажа невероятным об-

7. Авеллар Ж.К. Конь о трёх головах. Эйзенштейн для XXI века: сборник статей. М.: Garage, 2020. разом пересекается с эйзенштейновским образом новгородского воеводы Гаврило Олексича в исполнении Андрея Абрикосова. Зимние пейзажи Билибина («Ручей», «Зимка») перекликаются с пейзажными сценами зимнего леса - кадрами, предшествующими сражению.

При рассмотрении фильмов Эйзенштейна с искусствоведческой точки зрения и анализа включения в фильм тех или иных отсылок к живописным произведениям стоит помнить, что режиссёр никогда не преследовал цель буквального цитирования произведений искусства в своих работах и не стремился к чёткому построению кадров на основе прямого копирования живописных образов. В статье «Изобразительное искусство и кино Сергея Эйзенштейна» ${ }^{8}$ Наум Клейман писал о фактическом отсутствии прямых цитат из живописных произведений в фильмах мастера. Подлинное искусство кинематографа для Эйзенштейна, несомненно, не сводится к копированию и имеет вневременной, вечный характер. «Александр Невский» не был и не мог быть снят только как воспоминание о былой славе Руси. Проецирование через исторические события явлений настоящего, а через образы литературы, истории, и, как было показано в настоящей статье, живописи, образов действительности и вечности, - вот одна из основных идей Эйзенштейна.

Именно в «Александре Невском», до сих пор воспринимающемся многими как пусть и образцовый, но всё же сугубо «оборонный фильм», Эйзенштейн, по удивительно точному выражению Наума Клеймана, «использовал тот культурный запас, который ко времени начала работы над фильмом старательно стирался из нашей истории» 9 .

8. Клейман Н.И. Изобразительное искусство и кино Сергея Эйзенштейна // Русское искусство. № 2. М., 2019. С. 46-55.

9. https://arzamas.academy/materials/348 [дата обращения: 27 апр. 2021].

\section{БИБЛИОГРАФИЯ}

1. Библия. Книги Священного Писания Ветхого и Нового Завета.- М.: Издание Московской Патриархии, 1976.

2. Всеобщая история искусств в 6 т.-М.: Искусство, 1953.

3. Ильина Т.В. История искусств. Отечественное искусство. - М.: Высш. шк., 2000.

4. Клейман Н.И. Изобразительное искусство и кино Сергея Эйзенштейна // Русское искусство. - № 2.M., 2019. - C. 46-55.
5. Клейман Н.И. Александр Невский [Электронный ресурс]. — URL: https://arzamas.academy/materials/348

6. Лебедев А.К. В.В. Верещагин. Жизнь и творчество.М.: Искусство, 1958

7. Уленбрух Б. Миф как крамола. Догадки об «Александре Невском» // Киноведческие записки. - № 53. M., 2001 [Электронный ресурc].— URL: http://www. kinozapiski.ru/ru/article/sendvalues/760/ 
8. Шкловский В.Б. Литература и кинематограф. - Берлин, 1923.

9. Эйзенштейн для XXI века: сборник статей.- М.: Garage, 2020.

10. Эйзенштейн С. М. Избранные произведения в 6 Т.М.: Искусство, 1964.

11. Эйзенштейн С. М. Мемуары в 2 т. - М.: Редакция газеты «Труд»; Музей кино, 1997.- - (Живая классика).

12. Эйзенштейн С. М. Эйзенштейн / Eisenstein. Рисунки / Dessins / Drawings. - М.: Искусство, 1961.

13. Gallez, DW. 1978. Prokofiev-Eisenstein collaboration «Nevsky» and «Ivan» revisited. Cinema Journal, vol. 17 (2), 13-35. DOI: 10.2307/1225488

14. Polan, DB. 1977. Eisenstein as theorist + Eisenstein Sergey. Cinema Journal, vol. 17 (1), 14-29. DOI: $10.2307 / 1225467$
15. Prince, S. 1992. The Kuleshov-Effect + Film editing and Russian film history - Recreating the classic experiment. Cinema Journal, vol. 31 (2), 59-75, DOI: $10.2307 / 1225144$

16. Radunovich, D. 2017. The Shifting Protocols of the Visible: The Becoming of Sergei Eisenstein's The Battleship Potemkin, Film History, vol. 29 (2), 66-90. DOI: 10.2979/filmhistory.29.2.03

17. Rees, E. 2020. Design, Creativity, and Technology: The Khudozhnik in Russian Cinema of the Silent Era. Film History, vol. 32 (4), 60-90. DOI: 10.2979/ filmhistory.32.4.03 
Polina M. Stepanova

PhD in Art History, Associate Professor

Professor of Drama and Film Studies Department

St. Petersburg State Institute of Film and Television

e-mail: st-more@yandex.ru

Saint Petersburg, Russia

ORCID 0000-0001-8410-9086

DOI: 10.36340/2071-6818-2021-17-2-124-137

\section{REACTUALISATION OF THE RITUAL STRUCTURE IN THE PERFORMANCE OF JERZY GROTOWSKI'S SHAKUNTALA BY KALIDASA (1960)}

Summary: The famous Polish experimental director, Jerzy Grotowski, made an invaluable contribution to the development of the world modern theatrical process. His search during the theatrical (1959-1969) and paratheatrical (1970-1979) periods acutely raised the problem of the relationship between the actor and the audience in the process of creating and perceiving a performance or ritual... Grotowski's discoveries expanded and deepened the subject of the theatre, actualised the philosophy of perception of the field of joint action by the viewer-participant and the actor-creator. The article examines the fundamental foundations of the reconstruction of ritual structures and space in the earliest work of the Polish experimenter. On the example of the play Shakuntala based on the text of the classic Sanskrit drama by Kalidasa (1960), the main methods of working on new connections between the actor and the audience in the course of theatrical performance as a ritual form of complicity are examined. At this stage of the director's work, the primary expressive means are: deconstruction of the stage space, freedom from a clear division into the stage and the audience this allows the viewer to be included in the process of theatrical performance, makes him or her an active participant in the action; a specific selection of material for the production, a classic Indian text that simultaneous-

The famous Polish experimental director, Jerzy Grotowski, comprehending the results of the first period of his work, which lasted ten years from 1959 to 1969 and included all the theatrical works of the director, called this time "a return to ritual" ${ }^{1}$, the recreation of the "participation ceremony" ${ }^{2}$, entry into

1. Grotowski E. "Theater and ritual" // From Poor Theater to ArtGuide. Moscow: Artist. Rejisser. Teater, 2003. P. 100.

2. Ibid p. 101 ly arouses irony in the director, actors and viewers, and at the same time refers to the story of eternal love at the archetypal level; the use of children's drawings in the process of creating stage costumes as a kind of fetishisation of ritual time and space; creation of a unique bodily score of actors to achieve maximum penetration into the problems of the text and at the same time exclusion from it. The central figure in the production is the actor who, without penetrating the stage image at the level of the psychological score of the role, using a mode of existence close to the theatrical systems of $\mathrm{V}$. Meyerhold and $B$. Brecht, creates the score of the role, combining bodily techniques of life (M. Moss) and gesture in metaphysical dimension (M. Jousse). The performer's body acquires the functions of a conductor, creates a new type of communicative model of actor-viewer relations, reveals the dichotomy of visual mise-en-scene solution and the verbal textual part of the performance. Owing to the use of Indian sign systems, the traditional theatrical performance connects with the prototype of the ritual structure that is being created here and now in the living process of the action.

Keywords: ritual structure, bodily techniques, Sanskrit drama, anthropology of gesture, paratheatrical experiences, viewer-participant.

"confrontation with one's own roots" 3 . The choice of dramatic material for early performances determined the director's movement from the traditional theatrical performance to the completely new function of the paratheatrical experiments created by Grotowski in the 1970s, and to the philosophy of mundane ritual performance of the 1980s and 1990s.

3. Ibid p. 111 
The ancient Indian text of the classical Sanskrit drama of the 5th century became a unique transition from works with classical dramatic material of the European and Russian theatrical heritage to texts close to the origins of world theatrical culture. Orpheus by J. Cocteau (1959), Cain by J. Byron (1960), and Mystery-Buff by V. Mayakovsky (1960) were the first experimental performances of the Theater of 13 Rows in the small Polish town of Opole. However, after the staging of Shakuntala based on the Kalidasa text, a qualitative change took place in the repertoire policy of Grotowski's collective, and the pathos of returning to the ritual began to transform into the idea of "confrontation with one's own roots". The collision with the eastern dramatic structure became a catalyst in forming the philosophy of the search for a new form of theatrical performance, in which the audience and actors became accomplices in a single action. Immediately after the work on the embodiment of the Kalidasa text, the collective of the Theater of 13 Rows began a period based on traditional national drama, imbued with the Polish self and carrying folk cultural tradition in the structure of the texts. Such performances as Dziady by A. Mickiewicz (1961), Cordian by Y. Slovatsky (1962), Acropolis by S. Wyspianski (1962) made the theatre one of the most famous experimental sites in the world of the second half of the 20th century.

Working with Indian material revealed and exposed the problem of creating a single informational, sensory, energy field for the actor and the viewer, which was most important for Grotowski in all periods of his work. The search for theatre as "a dialogue with the public", the search for a specific form of this "dialogue" 4 attracted the director from his very first theoretical and practical works. Grotowski comprehended the history of world theatre through the prism of the relationship between the actor and the audience.

The director perceived the collision with India's early theatrical culture and ritual tradition as a playful, parody comic nature and, on the other hand, as a deeply personal, painfully own material for creating a performance. Earlier productions based on the texts of Byron and Mayakovsky attracted Grotowski with the greedy rebellion of the main characters; he was looking for material with the romantic pathos

4. Grotowski J. Dialog z widzem (Między "zabawą" a postawą wobec rzeczywistości) // Grotowski J. Teksty zebrane. Warszawa: Wydawnictwo Krytyki Politycznej, Instytut Teatralny im. Zbigniewa Raszewskiego, Instytut im. Jerzego Grotowskiego, 2012. P. 174. of new world order. He was attracted to the problems of classical drama by the ease of transferring the characters-fighters into the context of the youth counterculture of Europe in the early 1960s. However, Kalidasa's work is very far from Grotowski's main ideas, reflected in the productions of the late 1950 s and early 1960s.

In the production of Shakuntala, the famous stage set created by stage space architect Jerzy Gurawski can be considered to be the main provocation and direct reference to the culture of hippies and youth revolutions. The untrained viewer was first of all frightened and alarmed by the constructions on which the actors played, symbolising the phallus and vagina and referring in a playful way to the texts from the Kama Sutra, which Grotowski included in the main text of Kalidasa's play. The desire to shock the viewer, knock him or her out of the comfort zone with the help of visual images became the first stage in creating a unique Eastern European space for the formation of the structure of theatrical and, at the same time, ritual performance. On the one hand, the philosophy of destruction and ridicule and, on the other hand, a timid attempt to understand and appropriate the markers of a foreign culture is most easily embodied in the conscious deconstruction of the traditional stage division into a stage and an auditorium. Grotowski strived to preserve space for the viewers and the security of a dedicated acting space using the evocative, comically played attributes of early fertility cults from all cultures worldwide. Totemic images of phallic cults and cults of motherhood seem to become the protagonists of the play of Kalidasa, in the text of which, at the level of the most subtle poetic metaphors, the rhythm and symbolism of the early rituals of life and fertility are enclosed. The director used a clear division, inherent in ritual performances, into places for viewers and a place for the ritual - the space that is cleared and illuminated for the presence of gods or demons on earth. At the very beginning of the event, the shaman, who created the structure of the ritual action, outlined the sacred space in various ways, and most often, it contained cult, totemic attributes. In Grotowski's performance, the role of such attributes was assumed by the scenery. The actor who sang and performed complex acrobatic movements with the help of his or her own corporeality and physical contact with the decorative device maintained the distance from the audience necessary for the ritual. 
In the special Rules for Viewing by the Audience, and Especially for Reviewers, created by Grotowski and Ludwig Flaschen (director and co-author of stage versions of the performances of the Theater of 13 Rows), paragraph 4 states: "We are playing the eastern theatre. More precisely: pseudo-eastern. Through conventional gestures, the way of pronouncing the text, through the creation of a whole alphabet of conventional symbols, something like a synthesis of the Eastern theatre appears (and more a parody of the usual understanding of the Eastern theatre)" ${ }^{5}$. A kind of program or even, more precisely, the instruction for watching the performance in each of the points insisted on the ironic nature of the performance or the ironic attitude to the text of Kalidasa; it is not an attempt to reconstruct an Indian action, not an attempt to stage an Indian plot in a modern European director's theatre, but a specific game with an Indian culture, which, meanwhile, awakens "ritualism" 6 .

Working on the production of Shakuntala, Grotowski defended the theoretical part of the diploma in the speciality Director at the Solsky Higher Theater School in Krakow. A short text, The Game of Shiva, short notes on the margins of Kalidasa's play, is one of the fragments. "If I were to define our stage quest with one sentence, one term, I would appeal to the myth of Shiva's dance; I would say: 'We are having fun with Shiva', 'we are playing Shiva'. It is an attempt to absorb reality in its entirety" 7 . In Grotowski's philosophy, the dance of Shiva is a constant process of creation and destruction of being; it is the "dance of INTEGRITY" 8 . Grotowski dreamt of combining all possible expressive means of theatrical culture in the production, and thus, exhaust them, reach their limit and destroy, dissipate in exaggeration and relativity. Owing to the material of the Indian play, for the first time the director very accurately formulated the desire to destroy the main theatrical model, which was established in the theatre of the second half of the 20th century; he came to an idea which was very close to the searches of Richard Schechner in his fundamental work Theory of Performance: "The theatre has more in common with competition and sport than with play or ritual" ${ }^{9}$. Grotowski acutely felt

5. Siakuntala. Reglamin Patrzenia dla Widzów, a szczególnie Recenzentów // Flaszen L. Grotowski \& Company: Źródła I wariacje. Wrocław: Instytut im. Grotowskiego, 2014. P. 49.

6. Ibid p. 49.

7. Grotowski J. Gra w Sziwę // Grotowski J. Teksty zebrane. P. 180.

8. Ibid p. 179 .

9. Shehner R. Performance Theory. Moscow: V-A-C Press, 2020. P. 35. this dependence, he realized the impossibility of returning the theatre to its ritual roots. In the process of working on the production of Shakuntala, for the first time, problems arose related to the very idea of reconstructing the ritual structure. At the beginning of his work, Grotowski simplified as much as possible, schematized the main distinguishing features of the structure of ritual action and theatrical performance. For him, the fundamental difference was the function of the viewer in theatrical and ritual forms.

Grotowski's practical experiments posed the problem not of ritual as a phenomenon belonging to a particular culture or communication model of society ${ }^{10}$ but of the emergence of a ritual structure from the purely personal experience of the creator of the action. Eugenio Barba, an Italian director and founder of the International School of Theater Anthropology, became a kind of follower of Grotowski's ideas. Talking about his internship at the 13 Rows Theater-Laboratory in a slightly ironic manner, he wrote that Grotowski, working on Shakuntala, did not even have a remote idea about the traditional acting art of India. After a trip to this country and a short stay at the school of the traditional Indian dance theatre Katakhali, Barba himself understood that it is impossible ${ }^{11}$ to create mudras, symbolic gestures with hands, without a lively touch to Indian culture. This reproach for the absence of a living touch to the cultural tradition of Indian theatre reveals as accurately as possible a working model of creating a ritual performance, according to Grotowski. For the purity of the experiment, he needed a text that carried the ritual tradition of signs in the process of its presentation on stage; however, for the European consciousness and perception, these signs remained hidden, the Polish viewer would not have been able to read the authentic Indian mudras. A personal touch to the culture of India was much more important for Grotowski. The older he became, the more often, in his articles and conversations with students, he recalled one of the first books he read in childhood, The Paths of Yogis by the English journalist P. Brunton. The events of childhood during the Second World War, hunger, illness, memories of his mother were intertwined with the first thoughts of little Grotowski about the figure of the holy fool in

10. Levi-Strauss K. Structural Anthropology. Moscow: Academicheskiy Project, 2008. P. 555.

11. Barba E. Land of Ashes and Diamonds. My Apprenticeship in Poland. Followed by 26 Letters from Jerzy Grotowski to Eugenio Barba. Aberystwyth: Black Mountain Press, Center of Performance Research, 1999. Pp. 53-77. 
different cultures of the world, about the question "Who am I?", asked by old man Sri Rama Maharishi ${ }^{12}$. For Grotowski, personal contact with Indian philosophy in childhood was a projection of "confrontation with one's own roots". The basis for the search for the latest communications in modern theatre arose not from pragmatic conclusions about the nature of ritual and theatrical performance but on the basis of personal involvement. The awakening of his own perception of the reality of the text led the director from traditional theatre to acting and ritual, devoid of markers of the theatrical tradition. Such a relationship with the dramatic text chosen for the production is close to the problem of constructing a mobile drama of ritual action, when the main text for performers and viewers is only a canvas, into which fragments from other sources are easily interwoven (in Shakuntala, not only Kamasutra was used, but also the texts of the Laws of Manu, an ancient Indian collection of religious, moral and legal prescriptions), and, more importantly, fragments of their own attitude, open play, interpretation, rethinking of the structure of the development of action, characters and their places in the plot construction. It is no coincidence that working with a costume, Grotowski used children as the creators of visual images of the performance. Seventeen years after the premiere of Shakuntala, Flaschen recalled that sketches of theatrical costumes for this production were based on children's drawings. "We had a friend who was a teacher; he asked his students to draw a Knight, a Prince, a Girl. As a result, the costumes were extremely variegated, a little primitive; there was something oriental about them. It was exactly the feeling of the young people of the East" ${ }^{13}$. A child's view became the basis for the interpretation of the text. For the director, children's naive perception of the world seemed to be an analogue of the transparency and simplicity of the plot construction of the Sanskrit drama. However, the actor and partly the viewer in this position of the child seemed to have the opportunity to perceive the plot as something excessively simple, as a fairy tale, as a myth about the "eternal paradox of love" ${ }^{14}$, as an archetypal construction.

In the ancient Indian treatise Natya Shastra, dedicated to the art of theatrical performances, in

12. Osiński Z. Polskie kontakty teatralne z orientem w XX wieku: Studia. Gdańsk: słowo/obraz terytoria, 2008. Pp. 166-167.

13. Kumiega J. The Theatre of Grotowski. London and New York: Methuen, 1985. P. 31.

14. Ibid p. 30. the descriptions of various aspects of the spectacle, precise terms and categories are given, "which include two types of success (siddhi) of the performance - divine and human, two types of stage practice - life-like (lokadharmi) and conditional (natyadharmi)" $^{15}$. The interpenetration of lifelikeness and maximum conventionality became the main subject of Grotowski's search in the production of Shakuntala. "The performance can become a combination of a 'synthetic gesture', a 'danced' reality, a 'ritual' game" ${ }^{16}$. Stanislavsky's realistic theatre was rejected by the director at this stage of his search. The director did everything possible to ensure that the actors continue to be themselves, without becoming characters, always maintaining a clear distance between their own sense of open play and the role ${ }^{17}$. The way of the actor's existence in the first performances of the Theater of 13 Rows is close to Brecht's concept of alienation, to Meyerhold's biomechanical actor. Immersion in the play and simultaneous removal from the hero of the action is characteristic of the ritual techniques of shamans. The performer of the ritual dance, even in a trance state, maintains the border between himself and the entry of a spirit, a demon or divine essence ${ }^{18}$ into his body. Most often such co-presence of the divine and the human in the body and dance of a shaman is achieved with the help of a mask, doll or another sacred object. Grotowski made the work of his actors on stage as difficult as possible, using elaborate costume and make-up, oversaturated the score of the roles with acrobatic figures and bodily signs from the Indian tradition.

In his 1968 article "Theater and Ritual", Grotowski insisted that attempts to work with the ritual structure were primarily experiments with the stage and the desire to include the viewer in the process of theatrical performance ${ }^{19}$. Many researchers of the Polish experimenter's work consider this initial work with space to be a failure, a seeming projection of the

15. Lidova N. R. "Indian Theatre. At the Origins of Tradition" // Theater and Spectacular Forms of the East: From Ritual to Performance. Collection of articles. Issue. 1. Moscow: Russian University of Theater Arts - GITIS, 2012. P. 40.

16. Grotowski J. Gra w Sziwę // Grotowski J. Teksty zebrane. P. 180.

17. Bednorz Z. "Siakuntala", czyli cyrk z regulaminem // Misterium zgrozy I urzeczenia: Przedstawienia Jerzego Grotowskiego I Teatru Laboratorium. Wrocław: Instytut im. Jerzego Grotowskiego, 2006. P. 135

18. Eliade M. Shamanism. Archaic Techniques of Ecstasy, translated from French by V. Trylis. Moscow: Academicheskiy Project, 2014. P. 399.

19. Grotowski E. "Theatre and Ritual" // From Poor Theater to Art as a Guide. P. 351. 
wrong way of "transforming the 'scene-auditorium' relationship and transforming the audience into participants, which he saw as the basis of ritual. These attempts, although interesting, failed" ${ }^{20}$. In Kalidasa's play, "there are 34 characters, as well as hermits, disciples, courtiers and the royal retinue. In the play, the role of 'society' belonged to the audience" ${ }^{21}$. The stage space had complex architecture: the audience sat opposite each other, those who came to the performance saw both the actors in the centre of the room and the audience sitting opposite. This arrangement in space gave the observer a way of being in the production structure, similar to the way of being an actor. The viewer, observing not only the performance but also the other viewer, got the opportunity of an objective point of view; at the moment of the performance, he or she could see the reaction of others and have time to analyse it. In some moments of the performance, the light unexpectedly illuminated not the actors but the places for the audience ${ }^{22}$. The director, with the help of theatrical, expressive means, forced the viewer to take an active part in what was happening; he wanted to bring the viewer closer to the position of an accomplice of the ritual. Thus, diametrically opposed attitudes within one theatrical structure were exposed; the viewer had to remain aloof and capable of ironic analysis; however, at the same time, the director tried to create a space for the co-presence of the viewer-participant, who was inscribed in the structure of the development of the action and had to react in a certain way to the projection of integrity that arose at the moment of the actual process of creating the action, the magic dance of Shiva, creating and destroying at the same time.

From the sphere of viewer complicity, Grotowski deliberately left for the sphere of the specifics of the actor's existence in the play model, in the "ritualism" 23 or the "ritual" 24 of the ironic appropriation of the Indian manner of presentation. "It is quite possible that the detached qualities in his research work on this text, and his attempt to free the actor

20. Kosinsky D. Polish Theater. Stories. Moscow: Novoye Literaturnoye Obozrenie, 2018. P. 101.

21. Osiński Z. Grotowski i jego Laboratorium. Warszawa: Państwowy Instytut Wydawniczy, 1980. P. 82.

22. Bednorz Z. "Siakuntala", czyli cyrk z regulaminem // Misterium zgrozy I urzeczenia: Przedstawienia Jerzego Grotowskiego i Teatru Laboratorium. Wrocław: Instytut im. Jerzego Grotowskiego, 2006. P. 135

23. Siakuntala. Reglamin Patrzenia dla Widzów, a szczególnie Recenzentów // Flaszen L. Grotowski \& Company: Źródła i wariacje. P. 49

24. Grotowski J. Gra w Sziwę // Grotowski J. Teksty zebrane. P. 180 from the overwhelming influence of literature was one of the reasons why Grotowski chose Shakuntala for the theatre production of 13 Rows" ${ }^{25}$. However, in the methods and approaches of the director, the way of denying the text and the study of the possibility of "creating a system of signs in the European theatre" 26 more and more actualised the idea of not reconstructing ritual practices, but the method of crystallising the foundations of the ritual structure in the process of creating an action. Copying and even ironic transfer of bodily signs of Indian culture on the soil of European theatre turned them into "stereotypes" and "cliches of gesture" 27. It was in the process of working on Shakuntala that Grotowski "had to introduce voice training since it is impossible to create musical signs without a special preparation" 28

The play Shakuntala was based on gestural and vocal signs, as if, even against the will of Grotowski himself, the implementation of the text of the Sanskrit drama entailed the emergence of bodily and voice training for actors in the theatrical practice of the director. Even in the ironic form of playing with oriental rituals itself, a syncretic form of the actor's existence began to appear. The ninth chapter of Natya Shastra is devoted to the description of sign language. "Hand gestures were peculiar hieroglyphssymbols of a special 'silent' language, extremely rich and diverse. Demonstrating certain combinations of fingers, the participant in the drama could express all the main 'meanings' of human communication" ${ }^{29}$. In the first half of the 20th century, cultural anthropology posed the problem of the subtle interaction of gestures and the spiritual state of a person. In 1934, M. Moss, presenting the concept of "bodily techniques", spoke of similar and different features of the simplest physical body movements that are inherent in any person in the world; however, speaking about the techniques of birth, running, sitting, eating, and many others from the point of view of physiology, i.e. unconditional corporeality of human nature, the researcher came to an unexpected conclusion about the existence of certain body positions that could create "communication

25. Kumiega J. The Theatre of Grotowski. Pp. 28-29.

26. Grotowski E. "Theatre and Ritual" // From Poor Theater to Art as a Guide. P. 112

27. Ibid p. 113

28. Ibid p. 112

29. Lidova N. R. Drama and Ritual in Ancient India. Moscow: Nauka. Vostochnaya Literatura Publishing company Vostochnaya Literatura, 1992. P. 57. 
with God" ${ }^{30}$. Formulating the provisions of the new science "Anthropology of Gestures", M. Jousse refused to oppose "spirituality" and physical action ${ }^{31}$. Following Jousse and ethological theorists, a contemporary French anthropologist and culturologist, J. M. Pradier, insisted that "a gesture has a metaphysical dimension: it is a living person interacting with the cosmos" 32 . Grotowski's childhood enthusiasm for Indian philosophy and categories of Eastern culture was transformed into a purely personal selection of material for the production. Through fantasies about the bodily culture of Indian dancers and theoretical knowledge of yoga, the director made his way to a complex of bodily exercises created entirely by his imagination. And if the nature of the actor's existence in the play still bore, rather, a synthetic character, dictated by the already existing systems of non-psychological role creation, the training that took shape in the process of working on Shakuntala contained the potential for creating a syncretic actor who equally mastered the gesture sign, vocals - word, movement - the structure of the action, "all his efforts are aimed at uniting body, voice, mind and spirit" 33 .

Indian mudras paradoxically grew into the consciousness and physicality of Polish actors. The experience of the "cultural body" of Polish actors transformed the alphabet of Indian dance and turned it into comic body signs through which a more complex layer of cultural paradigms began to grow and form. A philosophy of uniting the Eastern sign and European bodily culture arose. Bodily signs came to life within the framework of the score of the ritual

30. Moss M. List of Bodily Techniques // Barba E., Savarese N. Dictionary of Theatrical Anthropology: The Secret Art of the Performer. Moscow: Artist. Rejisser. Teater, 2010. P. 227.

31. Jousse M. Études de psychologie linguistique. Le Style oral rythmique et mnémotechnique chez les Verbo-moteurs. Paris: Gabriel Beauchesne, 1925. P. 242.

32. Pradier J. M. "Flesh is Spirit: Ritual or the Problem of Action" // Religion, Ritual, Theater; Kharkiv: Gumanitarniy Center Publishing House, 2018. P. 203.

33. Shehner R. Performance Theory. P. 81. structure; the viewer immersed in the action "through a continuous process of production and interpretation of signs, which more and more conveys the essence of the world and increasingly orients the interpreting self towards this objectivity" ${ }^{34}$. Understanding of the body-sign within the framework of the performance took place at the level of the reactions of the audience themselves. Their shock from the set design, their attitude to the bright and at the same time simplified colours of costumes, the dichotomy of gesture and word, for example, a long love monologue that the actor uttered while standing on his head - all these directorial techniques allowed the viewer to be involved in the action at a symbolic level. A living sign process became the basis of a living ritual structure. One of the basic yoga asanas, Shirshasana, a headstand, continues to translate, at the level of bodily technique, one of the positions of the body, close to the divine comprehension of life. The text pronounced by the actor at this moment comes into conflict with the bodily code, if to accept the laws of perception of the European viewer; however, at the same time, it seems to become a catalyst for the very theme of the Sanskrit text. It is a story about the eternal love of mythological heroes. Thus, unexpectedly, the mockery turns into part of the ritual action. In the deconstruction of the Indian text, Grotowski found the integrity he was looking for; at the moment of destroying the Indian body, he created body signs that were close to the European perception of the eastern structure of the development of action. From dichotomies, a striving for an ideal body arose, which would become a guide in the ritual model of a new form of theatrical performance at the more mature stages of Grotowski's work, the period of poor theatre and the time of paratheatrical experiments.

34. Kon E. How Forests Think: Towards Anthropology Beyond Man, translated from English by A. Borovikova. Moscow: Ad Marginem Press, 2018. P. 70.

\section{REFERENCES}

1. Grotowski, E. 2003. "From Poor Theater to Art as a Guide", Collection of articles. Translated from Polish; introduction and notes by N. Bashinjaghyan. Moscow: Artist. Rejisser. Teater, p. 351.

2. Kon, E. 2018. How Forests Think: Towards Anthropology Beyond Man, translated from English by A. Borovikova. Moscow: Ad Marginem Press, p. 344.
3. Kosinsky, D. 2018. Polish Theater. Stories, translated from Polish by N. Nikolskaya, M. Yasinskaya; scientific ed. N. Yakubova. Moscow: Novoye Literaturnoye Obozrenie, p. 456.

4. Levi-Strauss, K. 2008. Structural Anthropology, translated from French by V. Ivanov. Moscow: Academicheskiy Project, p. 555. 
5. Lidova, N. R. 1992. Drama and Ritual in Ancient India. Moscow: Nauka. Vostochnaya Literatura Publishing company, p. 149.

6. Lidova, N. R. 2012. "Indian Theatre. At the Origins of Tradition", Theater and Spectacular Forms of the East: From Ritual to Performance. Collection of articles. Issue. 1 / Comp. D. Guseinova, E. Morozova. Moscow: Russian University of Theater Arts - GITIS, pp. 13-44.

7. Moss, M. 2010. "List of Bodily Techniques", Barba E., Savarese N. Dictionary of Theatrical Anthropology: The Secret Art of the Performer. Moscow: Artist. Rejisser. Teater, pp. 218-227.

8. Pradier, J. M. 2018. "Flesh is Spirit: Ritual or the Problem of Action", Religion, Ritual, Theater / Ed.B. Holma, B. Nielsen, K. Wedel; translated from English; Kharkiv: Gumanitarniy Center Publishing House, pp. 196-218.

9. Shehner, R. 2020. Performance Theory, translated from English by A. Aslanyan. Moscow: V-A-C Press, p. 488.

10. Eliade, M. 2014. Shamanism. Archaic Techniques of Ecstasy, translated from French by V. Trylis. Moscow: Academicheskiy Project, p. 399.

11. Barba, E. 1999. Land of Ashes and Diamonds. My Apprenticeship in Poland. Followed by 26 Letters from Jerzy Grotowski to Eugenio Barba. Translated from Ital- ian and Polish by J. Barba and E. Barba. Aberystwyth: Black Mountain Press, Center of Performance Research, p. 191.

12. Bednorz, Z. 2006. "Siakuntala", czyli cyrk z regulaminem, Misterium zgrozy I urzeczenia: Przedstawienia Jerzego Grotowskiego I Teatru Laboratorium, pod red. J. Deglera i G. Ziółkowskiego. Wrocław: Instytut im. Jerzego Grotowskiego, pp. 134-135.

13. Flaszen, L. 2014. Grotowski \& Company: Źródła I wariacje. Wrocław: Instytut im. Grotowskiego, p. 386.

14. Grotowski, J. 2012. Teksty zebrane. Warszawa: Wydawnictwo Krytyki Politycznej, Instytut Teatralny im. Zbigniewa Raszewskiego, Instytut im. Jerzego Grotowskiego, p. 1131.

15. Jousse, M. 1925. Études de psychologie linguistique. Le Style oral rythmique et mnémotechnique chez les Verbomoteurs. Paris: Gabriel Beauchesne, p. 242.

16. Kumiega, J. 1985. The Theatre of Grotowski. London and New York: Methuen, p. 290.

17. Osiński, Z. 1980. Grotowski i jego Laboratorium. Warszawa: Państwowy Instytut Wydawniczy, p. 412.

18. Osiński, Z. 2008. Polskie kontakty teatralne z orientem w XX wieku: Studia. Gdańsk: słowo/obraz terytoria, p. 317. 
Полина Михайловна Степанова

кандидат искусствоведения, доцент

профессор кафедры драматургии и киноведения

Санкт-Петербургского государственного института кино и телевидения e-mail: st-more@yandex.ru

Санкт-Петербург, Россия

ORCID 0000-0001-8410-9086

DOI: 10.36340/2071-6818-2021-17-2-124-137

\section{РЕАКТУАЛИЗАЦИЯ РИТУАЛЬНОЙ СТРУКТУРЫ В СПЕКТАКЛЕ ЕЖИ ГРОТОВСКОГО «САКУНТАЛА» КАЛИДАСЫ (1960)}

Аннотация: Знаменитый польский режиссёрэкспериментатор Ежи Гротовский внёс неоценимый вклад в развитие мирового современного театрального процесса, его поиски театрального (1959-1969) и паратеатрального (1970-1979) периодов остро поставили проблему взаимоотношений актёра и зрителя в процессе создания и восприятия спектакля или ритуала. Открытия Гротовского расширяют и углубляют предмет театра, актуализируют философию восприятия зрителемсоучастником и актёром-создателем поля совместного действа. Статья рассматривает фундаментальные основы реконструкции ритуальных структур и пространства в самом раннем творчестве польского экспериментатора. На примере спектакля «Сакунтала» по мотивам текста классической санскритской драмы Калидасы (1960) рассматриваются основные приёмы работы над новыми связями между актёром и зрителем в ходе театрального представления как ритуальной формы соучастия. Главными выразительными средствами на этом этапе работы режиссёра становятся: деконструкция сценического пространства, избавление от чёткого разделения на сцену и зрительный зал, данное построение позволяет включить зрителя в процесс театрального представления, делает его активным соучастником действия; специфический подбор материала для постановки, классический индийский текст, который одновременно вызы-

Знаменитый польский режиссёр-экспериментатор Ежи Гротовский, осмысляя итоги первого периода своего творчества, который длился десять лет с 1959 по 1969 год и включал все театральные работы постановщика, называл это время «возвращением к ритуалу» ${ }^{1}$, воссозданием «церемо-

1. Гротовский Е. Театр и ритуал // От Бедного Театра к Искусству-проводнику. М.: Артист. Режиссер. Театр, 2003. С. 100. вает иронию у режиссёра, актёров и зрителей, и вместе с тем отсылает на архетипическом уровне к прасюжету о вечной любви; использование детских рисунков в процессе создания сценических костюмов как некий момент фетишизации ритуального времени и пространства; создание уникальной телесной партитуры актёров для достижения максимального проникновения в проблематику текста и одновременно отстранение от него. Главной фигурой постановки становится актёр, который, не проникая в сценический образ на уровне психологической партитуры роли, используя способ существования, близкий театральным системам В. Мейерхольда и Б. Брехта, создаёт партитуру роли, совмещая телесные техники жизни (М. Мосс) и жест в метафизическом измерении (М. Жусс). Тело исполнителя обретает функции проводника, создаёт новый вид коммуникативной модели отношений актер - зритель, обнажает дихотомию визуального мизансценического решения и вербальной текстовой части представления. Традиционный театральный спектакль, благодаря использованию индийских знаковых систем, вступает в сложные связи с прообразом ритуальной структуры, созидаемой здесь и сейчас в живом процессе действа.

Ключевые слова: ритуальная структура, телесные техники, санскритская драма, антропология жеста, паратеатральные опыты, зритель-соучастник.

ниала участия» ${ }^{2}$, вступлением в «конфронтацию с собственными корнями» ${ }^{3}$. Выбор драматического материала для ранних спектаклей обуславливает движение режиссёра от традиционного театрального представления к совершенно новой функции паратеатральных опытов, созданных

2. Там же. С. 101.

3. Там же. С. 111. 
Гротовским в 1970-е годы, и к философии мирского ритуального действа 1980-1990-х годов. Древний индийский текст классической санскритской драмы $\mathrm{V}$ века становится уникальным переходом от работ с классическим драматургическим материалом европейского и русского театрального наследия к текстам, близким к истокам мировой театральной культуры. Первыми экспериментальными спектаклями Театра 13 рядов в небольшом польском городе Ополе были «Орфей» Ж. Кокто (1959), «Каин» Дж. Байрона (1960), «Мистериябуфф» В. Маяковского (1960). Но после постановки «Сакунталы» по мотивам текста Калидасы в репертуарной политике коллектива Гротовского произойдёт качественный перелом, и пафос возвращения к ритуалу начнёт трансформироваться в идею «конфронтации с собственными корнями». Столкновение с восточной драматической структурой становится катализатором в формировании философии поиска новой формы театрального представления, в котором зрители и актёры становятся соучастниками единого действа. Сразу после работы над воплощением текста Калидасы коллектив Театра 13 рядов начнёт этап, основанный на традиционной национальной драматургии, проникнутой польской самостью и несущей в структуре текстов народную культурную традицию. «Дзяды» А. Мицкевича (1961), «Кордиан» Ю. Словацкого (1962), «Акрополь» С. Выспяньского (1962) - именно эти спектакли сделают театр одной из самых знаменитых в мире экспериментальных площадок второй половины XX века.

Работа с индийским материалом проявляет и обнажает важнейшую для Гротовского во все периоды его творчества проблему создания единого информационного, чувственного, энергетического поля для актёра и зрителя. «Поиск театра как «диалога с публикой», поиск конкретной формы этого «диалога» ${ }^{4}$ привлекает режиссёра с самых первых его теоретических и практических работ. Гротовский постигает историю мирового театра сквозь призму отношений актёра и зрителей.

Столкновение с ранней театральной культурой и ритуальной традицией Индии воспринимается режиссёром как игровая, пародийная комическая природа, но, с другой стороны, и как глубоко

4. Grotowski J. Dialog z widzem (Między «zabawą» a postawą wobec rzeczywistości) // Grotowski J. Teksty zebrane. Warszawa: Wydawnictwo Krytyki Politycznej, Instytut Teatralny im. Zbigniewa Raszewskiego, Instytut im. Jerzego Grotowskiego, 2012. S. 174 личный, болезненно собственный материал для создания спектакля. Более ранние постановки по текстам Байрона и Маяковского привлекали Гротовского жадным бунтарством главных героев, он искал материал с романтическим пафосом нового мироустройства. Его притягивала в проблематике классической драмы лёгкость переноса персонажей-борцов в контекст молодёжной контркультуры Европы начала 1960-х годов. Но произведение Калидасы очень далеко от основных идей Гротовского, отразившихся в постановках конца 1950-х годов и начала 1960-го года.

В постановке «Сакунталы» главной провокацией и прямой отсылкой к культуре хиппи и молодёжных революций можно считать знаменитую декорационную установку, созданную архитектором сценического пространства Ежи Гуравским. Неподготовленного зрителя в первую очередь пугали и настораживали конструкции, на которых играли актёры, символизировавшие фаллос и вагину и отсылавшие в игровой форме к текстам из «Камасутры», которые были включены Гротовским в основной текст пьесы Калидасы. Желание шокировать зрителя, выбить его из зоны комфорта с помощью визуальных образов становится первым этапом в создании уникального восточноевропейского пространства для формирования структуры театрального и вместе с тем ритуального действа. Философия разрушения и насмешки, с одной стороны, и робкой попытки понять и присвоить маркеры чужой культуры - с другой, проще всего воплощается в сознательной деконструкции традиционного сценического разделения на сцену и зрительный зал. Гротовский старается сохранить места для зрителей и защищённость специального места для игры актёров, используя вызывающие комически обыгрываемые атрибуты ранних культов плодородия из всех культур мира. Тотемные изображения фаллических культов и культов материнства будто бы становятся действующими лицами самой пьесы Калидасы, в тексте которой на уровне тончайших поэтических метафор заключены ритмика и символика ранних ритуалов жизни и плодородия. Режиссёр использует свойственное ритуальным представлениям чёткое разделение на места для наблюдающих и место проведения ритуала, то пространство, которое очищено и освещено для присутствия богов или демонов на земле. Шаман, созидающий структуру ритуального действа, в самом начале события разными спо- 
собами очерчивает священное пространство, и чаще всего оно содержит культовые, тотемные атрибуты. Роль таких атрибутов в спектакле Гротовского берёт на себя декорация, и актёр поющий и исполняющий сложные акробатические движения с помощью собственной телесности и физического контакта с декорационным устройством, сохраняет необходимую для ритуала дистанцию со зрителями.

В специальных «Правилах для просмотра зрителями, а особенно для рецензентов», созданных Гротовским и Людвигом Фляшеном (завлитом и соавтором сценических версий спектаклей Театра 13 рядов) в пункте 4 указано: «Мы играем в восточный театр. Точнее: псевдовосточный. Через условные жесты, способ произнесения текста, через создание целого алфавита условных знаков возникает что-то вроде синтеза театра восточного (а более пародия на обычное понимание театра Востока)» 5 . Своеобразная программка или даже, точнее, инструкция по просмотру спектакля в каждом из пунктов настаивает на ироничной природе спектакля или ироничном отношении к тексту Калидасы, это не попытка реконструкции индийского действа, не попытка постановки индийского сюжета в современном европейском режиссёрском театре, но специфическая игра с индийской культурой, которая между тем пробуждает «обрядовость» 6

Работая над постановкой «Сакунталы», Гротовский защищает теоретическую часть диплома по специальности «Режиссёр» в Высшей театральной школе им. Л. Сольского в Кракове, одним из фрагментов является небольшой текст «Игра в Шиву», короткие заметки на полях пьесы Калидасы. «Если бы я должен был определить наши сценические поиски одним предложением, одним термином, я бы апеллировал к мифу о танце Шивы; сказал бы: «развлекаемся с Шивой», «мы играем в Шиву». В этом есть попытка впитать реальность во всей её полноте» 7 . Танец Шивы в философии Гротовского - это постоянный процесс созидания и разрушения бытия, это «танец ЦЕЛОСТНОСТИ» ${ }^{8}$. Гротовский мечтает соединить в постановке все возможные выразительные средства театральной культуры, и таким образом ис-

5. Siakuntala. Reglamin Patrzenia dla Widzów, a szczególnie Recenzentów // Flaszen L. Grotowski \& Company: Źródła I wariacje. Wrocław: Instytut im. Grotowskiego, 2014. S. 49.

6. Ibid. S. 49.

7. Grotowski J. Gra w Sziwę // Grotowski J. Teksty zebrane. S. 180.

8. Ibid. S. 179 черпать их, дойти до их предела и уничтожить, рассеять в утрированности и относительности. Благодаря материалу индийской пьесы, режиссёр впервые очень точно формулирует желание разрушения основной театральной модели, которая утвердилась в режиссёрском театре второй половины XX века, приходит к идее, максимально близкой поискам Ричарда Шехнера в его фундаментальной работе «Теория перформанса»: «У театра больше общего с соревнованиями и спортом, чем с игрой или ритуалом» ${ }^{9}$. Гротовский остро чувствует эту зависимость, он осознаёт невозможность возвращения театра к ритуальным корням. В процессе работы над постановкой «Сакунталы» впервые возникают проблемы, связанные с самой идеей реконструкции ритуальной структуры. В начале творчества Гротовский максимально упрощает, схематизирует основные отличительные черты структуры ритуального действа и театрального спектакля, для него фундаментальным отличием является функция зрителя в театральной и ритуальной формах.

Практические опыты Гротовского ставят проблему не ритуала как явления, принадлежащего некоторой культуре или коммуникационной модели общества ${ }^{10}$, а возникновения ритуальной структуры из сугубо личного опыта создателя действа. Своеобразным последователем идей Гротовского стал Эудженио Барба, итальянский режиссёр, создатель Международной школы театральной антропологии, который, рассказывая о своей стажировке в Театре-Лаборатории 13 рядов в немного ироничной манере, пишет, что Гротовский, работая над «Сакунталой», не имел даже отдалённого представления о традиционном актёрском искусстве Индии. Сам Барба после путешествия в эту страну и короткого пребывания в школе традиционного индийского танцевального театра катакхали понимал, что без живого прикосновения к индийской культуре создавать мудры, символические жесты кистями рук, невозможно ${ }^{11}$. Именно этот упрёк в отсутствии живого прикосновения к культурной традиции индийского театра и обнажает максимально точно рабочую модель создания ритуального действа по

9. Шехнер Р. Теория перформанса. М.: V-A-C Press, 2020. С. 35

10. См.: Леви-Строс К. Структурная антропология. М.: Академический Проект, 2008. 555 с.

11. Barba E. Land of Ashes and Diamonds. My Apprenticeship in Poland. Followed by 26 Letters from Jerzy Grotowski to Eugenio Barba. Aberystwyth: Black Mountain Press, Center of Performance Research, 1999. P. 53-77. 
Гротовскому. Для чистоты эксперимента ему требуется текст, который несёт в себе ритуальную традицию знаков в процессе его представления на сцене, но для европейского сознания и восприятия эти знаки остаются скрытыми, польский зритель не смог бы прочесть аутентичные индийские мудры. Намного важнее для Гротовского личное прикосновение к культуре Индии, чем старше он становится, тем чаще вспоминает в статьях и разговорах со студентами одну из первых книг, которую он прочёл в детстве, «Тропинками йогов» английского журналиста П. Брунтона. События детства во время Второй мировой войны, голод, болезнь, воспоминания о матери, переплетаются с первыми размышлениями маленького Гротовского о фигуре юродивого в разных культурах мира, о вопросе «Кто я такой?», заданном стариком Шри Рамой Махариши ${ }^{12}$. Личное прикосновение к индийской философии в детстве является для Гротовского проекцией «конфронтации с собственными корнями». Почва для поиска новейших коммуникаций в современном театре возникает не из прагматических выводов о природе ритуального и театрального действа, а на основе личной вовлеченности. Пробуждение собственного восприятия реальности текста ведёт режиссёра от традиционного театра к игре и ритуалу, лишённых маркеров именно театральной традиции. Подобные отношения с драматическим текстом, выбранным для постановки, близки проблеме конструирования подвижной драматургии ритуального действа, когда основной текст для исполнителей и наблюдающих является только канвой, в основу которой с лёгкостью вплетаются фрагменты из других источников (в «Сакунтале» использовалась не только «Камасутра», но и тексты Законов Ману, древнеиндийского сборника религиозно-моральных и правовых предписаний), но, что ещё важнее,фрагменты собственного отношения, открытой игры, трактовки, переосмысления структуры развития действия, персонажей и их мест в сюжетной конструкции. Не случайно на уровне работы с костюмом Гротовский использует в качестве создателей визуальных образов спектакля детей. Через семнадцать лет после премьеры «Сакунталы» Фляшен вспоминает, что эскизы театральных костюмов к этой постановке были выполнены на основе детских рисунков. «У нас был друг, кото-

12. $\mathrm{CM}_{\mathrm{M}}$ : Osiński Z. Polskie kontakty teatralne z orientem w XX wieku: Studia. Gdańsk: słowo/obraz terytoria, 2008. S. 166-167. рый был учителем; он попросил своих учеников нарисовать Рыцаря, Принца, Девушку. В результате костюмы были чрезвычайно пёстрыми, немного примитивными, в них было что-то восточное. Это было именно ощущение молодыми людьми Востока» ${ }^{13}$. Взгляд ребёнка стал основой для трактовки текста. Наивность детского восприятия мира кажется режиссёру аналогом прозрачности и простоты сюжетной конструкции санскритской драмы. Но актёр и отчасти зритель в этой позиции ребёнка будто бы имели возможность воспринять сюжет как что-то избыточно простое, как сказку, как миф о «вечном парадоксе любви» ${ }^{14}$, как архетипическую конструкцию.

В древнем индийском трактате «Натьяшастра», посвящённом искусству театральных представлений, в описаниях различных аспектов зрелища даны точные термины, категории, «к числу которых относятся два вида успеха (сиддхи) спектакля - божественный и человеческий, две разновидности сценической практики - жизнеподобная (локадхарми) и условная (натьядхарми)» ${ }^{15}$. Взаимопроникновение жизнеподобия и максимальной условности становится главным предметом поиска Гротовского в постановке «Сакунталы». «Спектакль может стать соединением «синтетического жеста», «танцуемой» реальности, игры «ритуальной» ${ }^{16}$. Реалистический театр К. Станиславского отвергается режиссёром на этом этапе поисков. Режиссёр делает всё возможное, чтобы актеры продолжали оставаться собой, не становясь персонажами, всегда сохраняя чёткую дистанцию между собственным ощущением открытой игры и ролью ${ }^{17}$. Способ существования актёра в первых спектаклях Театра 13 рядов близок к концепции отчуждения Брехта, к биомеханическому актёру Мейерхольда. Погружение в игру и одновременное отстранение от героя действа свойственно ритуальным техникам шаманов. Исполнитель ритуального танца даже в состоянии транса сохраняет границу между собой и вхождением в его тело духа, демона или бо-

13. Цит. по: Kumiega J. The Theatre of Grotowski. London and New York: Methuen, 1985. P. 31.

14. Ibid. P. 30.

15. Лидова Н.Р. Индийский театр у истоков традиции // Театр и зрелищные формы Востока: От ритуала к спектаклю: Сборник статей. Вып. 1. М.: Российский университет театрального искусства — ГИТИС, 2012. С. 40.

16. Grotowski J. Gra w Sziwę // Grotowski J. Teksty zebrane. S. 180.

17. Bednorz Z. «Siakuntala», czyli cyrk z regulaminem // Misterium zgrozy I urzeczenia: Przedstawienia Jerzego Grotowskiego I Teatru Laboratorium. Wrocław: Instytut im. Jerzego Grotowskiego, 2006. S. 135. 
жественной сущности ${ }^{18}$, чаще всего достигается подобное соприсутствие божественного и человеческого в теле и танце шамана с помощью маски, куклы или другого сакрального предмета. Гротовский максимально усложняет работу своих актёров на сцене, используя сложный костюм и грим, перенасыщая партитуру ролей акробатическими фигурами и телесными знаками из индийской традиции.

Гротовский в статье «Театр и ритуал» в 1968 году настаивает на том, что попытками работы с ритуальной структурой были в первую очередь эксперименты со сценической площадкой и желание включить зрителя в процесс театрального представления ${ }^{19}$. Многие исследователи творчества польского экспериментатора считают эту первоначальную работу с пространством неудачей, кажущейся проекцией неверного пути «преобразования отношений «сцена - зрительный зал» и превращения зрителей в участников, в чём видел основу ритуальности. Эти попытки, хотя и были интересны, потерпели фиаско» ${ }^{20}$. В пьесе Калидасы «34 действующих лица, а также отшельники, ученики, придворные и царская свита. В спектакле роль «общества» принадлежала зрителям» ${ }^{21}$. Сложная архитектура сценического пространства, зрители сидели друг напротив друга, пришедшие на спектакль видели и актёров в центре помещения, и зрителей, сидящих напротив. Подобное расположение в пространстве даёт наблюдающим способ существования в структуре постановки, сходный со способом существования актёра. Зритель, наблюдающий не только представление, но и другого зрителя, получает возможность объективной точки зрения, в момент самого спектакля может увидеть реакцию другого и успеть проанализировать её. В некоторые моменты представления свет неожиданно освещал не актёров, а именно места для зрителей ${ }^{22}$. Режиссёр с помощью театральных выразительных средств вынуждал наблюдающего принимать активное участие в происходящем, желал

18. См.: Элиаде М. Шаманизм. Архаические техники экстаза. М.: Академический Проект, 2014. 399 с.

19. Гротовский Е. Театр и ритуал // От Бедного Театра к Искусству-проводнику. С. 104-105.

20. Косинский Д. Польский театр. Истории. М.: Новое литературное обозрение, 2018. С. 101.

21. Osiński Z. Grotowski i jego Laboratorium. Warszawa: Państwowy Instytut Wydawniczy, 1980. S. 82.

22. Bednorz Z. «Siakuntala», czyli cyrk z regulaminem // Misterium zgrozy I urzeczenia: Przedstawienia Jerzego Grotowskiego i Teatru Laboratorium. Wrocław: Instytut im. Jerzego Grotowskiego, 2006. S. 135. приблизить смотрящего к позиции соучастника ритуала. Так обнажались диаметрально противоположные установки внутри одной театральной структуры, зритель должен был оставаться отчужденным и способным к ироническому анализу, но вместе с тем режиссёр пытался создать пространство соприсутствия зрителя-соучастника, который вписан в структуру развития действия и должен определённым образом реагировать на проекцию целостности, возникающую в момент реального процесса создания действа, магического танца Шивы, созидающего и разрушающего одновременно.

Из сферы зрительского соучастия Гротовский сознательно уходит в сферу специфики актёрского существования в игровой модели, в «обрядовости» ${ }^{23}$ или в «ритуальности» ${ }^{24}$ иронического присвоения индийской манеры представления. «Вполне возможно, что одной из причин, по которой Гротовский выбрал «Сакунталу» для постановки в Театре 13 рядов, были отстранённые качества в его исследовательской работе над этим текстом, и его попытка освободить актёра от подавляющего влияния литературы» ${ }^{25}$. Но путь отрицания текста и исследование возможности «создания системы знаков в европейском театре» ${ }^{26}$ всё больше актуализируют в приёмах и подходах режиссёра идею не реконструкции ритуальных практик, а метод кристаллизации основ ритуальной структуры в процессе создания действа. Копирование и даже иронический перенос телесных знаков индийской культуры на почву европейского театра превращал их в «стереотипы» и «штампы жеста» ${ }^{27}$, именно в процессе работы над «Сакунталой» Гротовскому «пришлось ввести голосовой тренинг, так как невозможно создавать музыкальные знаки, не обладая специальной подготовкой» 28.

Спектакль «Сакунтала» был построен на жестикуляционных и вокальных знаках, будто бы даже помимо воли самого Гротовского реализация текста санскритской драмы повлекла за собой возникновение в театральной практике режиссёра телесных и голосовых тренингов для

23. Siakuntala. Reglamin Patrzenia dla Widzów, a szczególnie Recenzentów // Flaszen L. Grotowski \& Company: Źródła i wariacje. S. 49.

24. Grotowski J. Gra w Sziwę // Grotowski J. Teksty zebrane. S. 180.

25. Kumiega J. The Theatre of Grotowski. P. 28-29.

26. Гротовский Е. Театр и ритуал // От Бедного Театра к Искусству-проводнику. С. 112

27. Там же. С. 113.

28. Там же. С. 112. 
актёров, даже в иронической форме игры с восточным ритуалом сама собой стала возникать синкретическая форма существования актёра. Девятая глава «Натьяшастры» посвящена описанию языка жестов. «Жесты рук представляли собой своеобразные иероглифы-символы особого «немого» языка, чрезвычайно богатого и разнопланового. Демонстрируя те или иные комбинации пальцев, участник драмы мог выразить все основные «смыслы» человеческого общения» ${ }^{29}$. Культурная антропология ещё в первой половине XX века поставила проблему тонкого взаимодействия жестов и духовного состояния человека. М. Мосс в 1934 году, представляя концепцию «телесных техник», говорит о схожих и различных чертах простейших физических движений тела, которые присущи любому человеку в мире, но рассуждая о техниках рождения, бега, сидения, принятия пищи и многих других именно с точки зрения физиологии, т.е. безусловной телесности человеческой природы, исследователь приходит к неожиданному выводу о существовании некоторых положений тела, способных создать «коммуникацию с Богом» ${ }^{30}$. М. Жусс, формулируя положения новой науки «Антропологии жестов», отказывается от противопоставления «духовности» и физического действия ${ }^{31}$. Современный французский антрополог и культуролог Ж.-М. Прадье вслед за Жуссом и теоретиками этологами настаивает, что «жест имеет метафизическое измерение: это живой человек, взаимодействующий с космосом» ${ }^{32}$. Детская увлечённость Гротовского индийской философией и категориями восточной культуры трансформируется в сугубо личный отбор материала для постановки. Сквозь фантазии о телесной культуре индийских танцовщиков и теоретические знания йоги режиссёр продирается к созданному полностью собственным воображением комплексу телесных упражнений. И если природа существования актёра в спектакле всё ещё несёт, скорее, характер синтетический, продиктованный уже существующими системами

29. Лидова Н.Р. Драма и ритуал в древней Индии. М.: Наука. Издательская фирма «Восточная литература», 1992. С. 57.

30. Мосс М. Перечень телесных техник // Барба Э., Саварезе Н. Словарь театральной антропологии: Тайное искусство исполнителя. М.: Артист. Режиссёр. Театр, 2010. С. 227.

31. См.: Jousse M. Études de psychologie linguistique. Le Style oral rythmique et mnémotechnique chez les Verbo-moteurs. Paris: Gabriel Beauchesne, 1925. 242 p.

32. Прадье Ж.-М. Плоть есть дух: Ритуал или проблема действия // Религия, ритуал, театр. Харьков: изд-во «Гуманитарный Центр», 2018. С. 203. непсихологического создания роли, то тренинги, сформировавшиеся в процессе работы над «Сакунталой», содержат в себе потенцию к созданию синкретического актёра, владеющего в равной степени жестом-знаком, вокалом-словом, движением-структурой действа, «все его усилия направлены на то, чтобы объединить тело, голос, разум и дух» ${ }^{33}$.

Индийские мудры парадоксальным образом врастают в сознание и в саму телесность польских актёров, опыт «культурного тела» польских актёров трансформирует алфавит индийского танца и превращает его в комические тела-знаки, сквозь которые начинает прорастать и формироваться более сложный пласт культурных парадигм. Возникает философия соединения восточного знака и европейской телесной культуры. Телесные знаки оживают в рамках партитуры ритуальной структуры, зритель погружается в действо «через непрерывный процесс производства и интерпретации знаков, который всё лучше передает суть мира и всё чаще ориентирует интерпретирующую самость на эту предметность» ${ }^{34}$. Осмысление тела-знака в рамках спектакля происходит на уровне самих реакций зрителей. Их шок от декорационного решения, их отношение к ярким и вместе с тем упрощённым краскам костюмов, дихотомия жеста и слова, например, длинный любовный монолог, который актёр произносил стоя на голове, - все эти режиссёрские приёмы позволяют зрителю включаться в действо на символическом уровне. Живой знаковый процесс становится основой живой ритуальной структуры. Одна из базовых асан йоги, Ширшасана, стойка на голове, продолжает транслировать на уровне телесной техники одно из положений тела, близкое к божественному осмыслению бытия. Текст, произносимый актёром в этот момент, вступает в конфликт с телесным кодом, если принять законы восприятия европейского зрителя, но вместе с тем, будто бы становится катализатором самой проблематики санскритского текста. Это история о вечной любви мифологических героев. Так неожиданным образом насмешка превращается в часть ритуального действа. Гротовский обретает в деконструкции индийского текста искомую им целостность, разрушая индийское тело, он в этот момент создает тела-знаки, близкие европейско-

33. Шехнер Р. Теория перформанса. С. 81.

34. Кон Э. Как мыслят леса: к антропологии по ту сторону человека. М.: Ад Маргинем Пресс, 2018. С. 70. 
му восприятию восточной структуры развития действия. Из дихотомий возникает стремление к идеальному телу, которое станет проводником в ритуальной модели новой формы театрального действа на более зрелых этапах работы Гротовского, период бедного театра и время паратеатральных опытов.

\section{БИБЛИОГРАФИЯ}

1. Гротовский Е. От Бедного Театра к Искусствупроводнику: Сб. ст. / Пер. с пол., вступ. ст. и примеч. Н.3. Башинджагян. - М.: Артист. Режиссёр. Театр, 2003. - 351 c.

2. Кон Э. Как мыслят леса: к антропологии по ту сторону человека / Эдуардо Кон; пер. с англ. А. Боровикова. - М.: Ад Маргинем Пресс, 2018. - 344 с.

3. Косинский Д. Польский театр. Истории / Дариуш Косинский; пер. с польского Н. Никольской, М. Ясинской; науч. ред. Н. Якубова. - М.: Новое литературное обозрение, 2018. - 456 с

4. Леви-Строс К. Структурная антропология / Пер. с фр. Вяч. Вс. Иванова. - М.: Академический Проект, 2008. - 555 c.

5. Лидова Н. Р. Драма и ритуал в древней Индии. - М.: Наука. Издательская фирма «Восточная литература», 1992. - 149 с.

6. Лидова Н.Р. Индийский театр. у истоков традиции // Театр и зрелищные формы Востока: От ритуала к спектаклю: Сборник статей. - Вып. 1 / Сост. Д.А. Гусейнова, Е.Б. Морозова.- М.: Российский университет театрального искусства - ГИТИС, 2012. - C. 13-44.

7. Мосс М. Перечень телесных техник // Барба Э., Саварезе Н. Словарь театральной антропологии: Тайное искусство исполнителя.-М.: Артист. Режиссёр. Театр, 2010.- С. 218-227.

8. Прадье Ж.-М. Плоть есть дух: Ритуал или проблема действия // Религия, ритуал, театр / Под ред. Б. Холма, Б.Ф. Нилсена, К. Ведель; пер. с англ. - Харьков: изд-во «Гуманитарный Центр», 2018. - С. 196-218.

9. Шехнер Р. Теория перформанса / Ричард Шехнер. Пер. с англ. А. Асланян. - М.: V-A-C Press, 2020.488 c.
10. Элиаде М. Шаманизм. Архаические техники экстаза / Пер. с фр. В. Трылис. - М.: Академический Проект, 2014. - 399 c.

11. Barba E. Land of Ashes and Diamonds. My Apprenticeship in Poland. Followed by 26 Letters from Jerzy Grotowski to Eugenio Barba / trans. from Italian and Polish by J. Barba and E. Barba. - Aberystwyth: Black Mountain Press, Center of Performance Research, 1999. - $191 \mathrm{p}$.

12. Bednorz Z. «Siakuntala», czyli cyrk z regulaminem // Misterium zgrozy I urzeczenia: Przedstawienia Jerzego Grotowskiego I Teatru Laboratorium / pod red. J. Deglera i G. Ziółkowskiego. - Wrocław: Instytut im. Jerzego Grotowskiego, 2006. - S. 134-135.

13. Flaszen L. Grotowski \& Company: Źródła I wariacje / Ludwik Flaszen. - Wrocław: Instytut im. Grotowskiego, 2014. - 386 s.

14. Grotowski J. Teksty zebrane / Jerzy Grotowski.Warszawa: Wydawnictwo Krytyki Politycznej, Instytut Teatralny im. Zbigniewa Raszewskiego, Instytut im. Jerzego Grotowskiego, 2012. - 1131 s.

15. Jousse M. Études de psychologie linguistique. Le Style oral rythmique et mnémotechnique chez les Verbomoteurs / Marcel Jousse. - Paris: Gabriel Beauchesne, 1925. - $242 \mathrm{p}$.

16. Kumiega J. The Theatre of Grotowski / Jenifer Kumiega. — London and New York: Methuen, 1985. $290 \mathrm{p}$.

17. Osiński Z. Grotowski i jego Laboratorium / Zbigniew Osiński. - Warszawa: Państwowy Instytut Wydawniczy, 1980. - $412 \mathrm{~s}$.

18. Osiński Z. Polskie kontakty teatralne z orientem w XX wieku: Studia / Zbigniew Osiński. - Gdańsk: słowo/ obraz terytoria, 2008. - $317 \mathrm{~s}$. 
Yulia A. Vaserchuk

Professor, Candidate of Art History

Institute of Contemporary Art, Department of Graphic Design

e-mail: vasse@yandex.ru

Moscow, Russia

ORCID 0000-0002-0111-8874

DOI: 10.36340/2071-6818-2021-17-2-138-150

\section{PROJECT CULTURE OF TEAM STRATEGIES}

Summary: Modern forms of design activities that contribute to the development of professional design are considered in the article. The principles of designers' teamwork, which are similar in structure but differ in content, are compared. In one case, this is teamwork; in the other, groups of like-minded people. It has been proved that colleagues unite by common values, meanings, and ideological attitudes to form a picture of the future and formulate a global vision of professional strategies, design principles, methods, and attitudes to improve the quality of life. By joint intellectual and spiritual efforts, like-minded people form the vector of modern design activity. The professional elite acts as the driving force behind the evolutionary transformation of contemporary design, reveals the potential of conscious design and advanced design thinking, determines the place of design in the future professions, and sets moral standards of behaviour.

The types of project design thinking (from engineering, creative - to artistic and resource one) are presented as

In modern practice, design is often represented by an individual form of project activity, as evidenced by a significant increase in remote work and freelancing. The demand for freelancers in large organisations doubled from 2017 to 2020 [Bentley, 2019]. A freelancer can contribute to a company without being part of it [Singh, 2019]. Such individuals can transform companies' fortunes, allowing them to expand significantly to meet increased demand or complement teamwork with experiences that companies could never have obtained or justified otherwise [Bentley, 2019].

When defining freelancing principles, it is essential to understand that such work involves remote but, nevertheless, quite close interaction with colleagues. One can design remotely from anywhere, but the distance does not mean separation from commu- the results of the individual creativity of team members. The continuous development of certain areas of design thinking and the acquisition of competencies based on individual capabilities provides designers with long-term professional development, regardless of external conditions. Moreover, an honest attitude towards oneself and one's abilities promotes a deep understanding of the profession, which allows the development of new types of design that respond to deep human needs.

In conclusion, self-knowledge, gained in a collective creative act, promotes the development of individual abilities and leads to intellectual and spiritual co-evolution.

Keywords: Project design culture, team, a group of like-minded people, teamwork, freelance, collective design, competencies, types of thinking, strategy, conceptual design, project design thinking, co-evolution, Russian design.

nications. To earn money, a freelancer needs partners. Thus, freelancing is not as isolated an activity as it might seem [Ghosh, 2017]. However, a designer, especially when working remotely, is rarely seen as a team player within a design team. $\mathrm{He}$ or she is not involved in creating team strategies; the intellectual potential of a freelancer is seldom used in fundamental development. In the modern world, the ability of a designer to visualise an already formed image, to realise someone else's vision is appreciated. Marketing strategists lead the design process and choose directions based on consumer preferences, sometimes actively developing them.

The development of freelancing, the positioning of design as an individual creative activity, as well as the myth that design is a profession for introverts, in a sense, hinder the development of collective forms 
of design, prevent designers from being aware of themselves as part of a team, and prevent professionals from becoming active participants in collective intellectual co-creation. Only a fraction of designers realise that team design surpasses the capabilities of an individual due to its multidimensional scope, which enriches the final results of activities. The resource of teamwork in design has not been fully identified and not fully updated. In reality, even as a result of the proliferation of freelancing and other "non-team" work formats, design has every opportunity to implement group practices, integrate interdisciplinary project sessions, and develop design tools in line with creative team technologies.

In the spring of 2020, the covid-19 pandemic and the associated self-isolation fully demonstrated that remote communication does not interfere with productive teamwork in many professional areas, including design. In a difficult period for everyone, project sessions, seminars organised on the platforms Skype, Webinar, Webex, Zoom, and others allowed specialists to unite to solve urgent design and business problems, strengthen human ties, and develop interpersonal communication.

In the modern world, with an increase in the level of stress, the factor of psychological support in the form of a voluntary union of people comes to the fore. This natural reaction of society stops disunity, compensates for the lack of quality communication, contributes to the emergence and strengthening of like-mindedness. At the same time, consent is viewed not only as an intellectual but also as a psychicemotional, spiritual unity. Human capital, for which the team serves as support since the value of the individual contribution to the common cause of all participants is multiplied many times over, is of particular importance. A team is an organism that unites people by a common cause and a common spirit.

Currently, the concept of teamwork, which means the ability of a group of people to work well together, is widespread [Cambridge Advanced Learner's Dictionary, 2019]. Also, the meaning includes working to achieve common goals and tasks most acceptably and effectively by a group of interconnected people, a team... The word "work" in the concept of teamwork is the key, meaning-forming basis of the phrase. Effective teamwork considers the knowledge, skills, abilities and other characteristics of its members [Bell, 2015: 181]. Group cohesion is one of the most researched constructs affecting team efficiency and productivity [Severt, 2015: 3], contributing sig- nificantly to team success. Research into cohesion mechanisms can diagnose, monitor, and improve team performance [Grossman, 2015: 147]. Special attention is paid to two criteria of team cohesion the organisational commitment of team members and their social competence [Hirunyawipada, 2015: 855], as well as efficiency factors based on well-being: subjective well-being (SWB) and psychological well-being (PWB) [Vanhove, 2015: 53]. Interpersonal relationships of team members, such as friendship, do not have a positive relationship with the consistency of tasks and the desirable qualifications of the ideas generated by the group [Hirunyawipada, 2015: 855]. However, there is a positive relationship between team effectiveness and the emotional state of the group. Associations that develop group emotional consciousness and can manage emotional connections within the group become more productive and learnable [Ghuman, 2016: 51]. For the teamwork model, professional, business relationships formed to solve corporate problems optimally are decisive; and emotional closeness, empathy, seems to be a kind of "safety cushion" in interpersonal relationships.

In Russian practice, in addition to the teamwork model appropriate for business relations, a form of uniting people on the principle of like-mindedness has been formed, which in fact goes beyond the simple unity of participants with a similar mentality and way of thinking; it implies cohesion at a deeper spiritual level. Emotional unity and creative atmosphere are presented not only as tools that form cohesion but also as the business intentions of professional groups, the existential meaning of their creativity. In most cases, people meet, unite for mutual support and mutual assistance. Often, a common cause is just a pretext for team interaction. The luminary of the Russian design culture, V. Glazychev, noted that "at the seminar, people come together; there is a mutual exchange between them, and it is not so important whether any project will arise here and now or not. If it appears, it is great; if it does not, it is okay: it will appear next time. Most importantly, a different experience has been achieved. The participants looked at other people, heard different opinions, saw different approaches, which is very important... Experience is transmitted only in this way - from person to person" [Glazychev]. The presence of goodwill in professional creative associations and unions seems to be significant. People are ready for meetings and project sessions, having internal motivation, interest 
in the innovative development of design, in the enrichment of the industry, its individual development in the process of gaining collective experience. Joint "living" of the creative process in a team of people close in spirit greatly enriches all its participants, fills their lives with energy.

"A team of like-minded people" - seems to be the most accurate definition for this kind of group. At the same time, like-minded people are people united by a common intellectual and cultural level, a similar vector of spiritual development, sharing similar values and ideological attitudes. This cultural feature has always been a certain obstacle to the rapid and successful implementation of Western business models, forms of organisation and management of project activities, business communications and teamwork standards into Russian project processes. In our country, joint design is most often based on the principles of openness, reflectivity, and most importantly, the creation of innovative projects, methodological developments, and other "products" of collective thought activity that enrich practice [Marfin, 2005: 15]. It has always been important for representatives of the professional environment (higher education, design practice) to agree on common "vanishing points" and then build a methodological framework for design, relying on a mature conceptual base with various individual theoretical developments and practical experience.

Modern Russian designers still remember and honour the traditions of artistic design, the theoretical and methodological experience of the AllRussian Research Institute of Technical Aesthetics (VNIITE), the Institute's project seminars, conferences, publications, famous throughout the Soviet Union, focused on the development of creative reflection, the development of a professional-critical approach to the results of their own activities, the vision of its objects in a broad socio-cultural context [Jerdev, 2007: 8]. The results of collective project activities are included in numerous reports on the scientific and methodological work of the Institute, in methodological recommendations based on the results of project seminars, in materials of international and Russian scientific conferences, in pre-project and project documentation: explanatory notes to artistic design proposals, in reports on the results of the examination of Russian and foreign design products.

Teamwork is somewhat different from the traditional forms of project co-creation for the post-
Soviet space. First of all, the difference is in goal setting, which creates corporate strategies and progressive business solutions. For Russian models of co-creation, goal-setting, as a rule, is guided by the principle "to make the world a better place". Also, a distinctive feature is a method of recruiting specialists into teams. For a team of like-minded people, friendship and human acceptance are significant motives for unity. The teamwork model presupposes the integration of team members according to the "constructor" principle, combining the knowledge, skills and abilities required for project development. For successful work, groups of people are formed with competencies in several disciplines and additional skills that allow professionals to work, listen and learn from each other while jointly solving problems [Redström, 2017: 11]. The combinatorial principle of team modelling, based on the competencies and project experience of the participants, helps to unite people for the implementation of projects of different directions. Short distances, successfully covered by the team together, presuppose the further development and transformation of teams into new associations to cover the next distances. The interchangeability and flexibility of teams formed on a competency basis enable people to get acquainted, exchange experience and knowledge, broaden their horizons and learn how to interact with representatives of different fields of activity effectively. Depending on the composition of the created team, the group members each time look for a new method of practical problem solving, carry out personal growth, and develop the leader's personal qualities. Leaders of successful collaborations demonstrate increased emotional and social competence, take actions to improve and progress in the future, remain mission-oriented and ready for a change to meet current challenges [Madden, 2015: 18].

The consistency of the value range of its participants with the general preferences of corporationscustomers is an essential factor affecting the efficiency of teamwork project work. "The perception of different types of values and their manifestation would be useful for managers in understanding how to identify the causes of the gap between the personal values of employees and the values of the organisation and take targeted actions to ensure the consistency of values within companies" [Vveinhardt, 2017: 2003]. In Western forms of teamwork, management of value models serves, as a rule, the strategic goals of companies and the paradigm of 
the market economy in general. Today, team design, subject to the observance of agreed values, has become a driver of successful design developments in the field of brand development, individual products, services and business areas for foreign and many Russian companies. Teamwork for design is an effective tool for finding solutions, including user-centric research to prototype future successful designs, as well as collective creativity to strengthen individuals, teams and organisations [Madden, 2015: 18]. Strategic design, based on teamwork, has established itself as an effective weapon in the competitive struggle; it brought design methods to the level of creating social prerequisites for the emergence of in-demand goods and services. It became capable of influencing society, ecology, demography and other spheres of life through products and services, patterns of consumer behaviour and communication.

In Russian design, strategy is seen as something more complex, going beyond the solution of specific business problems of individual corporations. The tactical level of social design is also perceived to be insufficient in the absence of global design philosophy. For collectives of like-minded people, the primary factor in uniting people is the consistency of the value series, the commonality of deep ideological attitudes, a common understanding of the goals and meanings of joint intellectual and project activities. This approach contributes to the joint passage of long-term distances. It also has a high potential for developing complex strategic design and forming a project philosophy. The consistency of the fundamental foundations and meanings of design as a future design technology allows a team of like-minded people to carry out a design based on a common value paradigm for a long-term perspective.

Western corporate culture, business communications, teamwork formats sometimes look lightweight for people who grew up in the Soviet and post-Soviet eras. Corporate culture often becomes an object of ridicule in Russia since it does not reach the level of true culture as a complex of philanthropy, nobility and intelligence in a sense familiar to compatriots. A team of like-minded people, united by spiritual values and a common desire to change the world for the better, is needed to carry out complex strategic project activities. Such globality of design installations is formed by the revolutionary spirit of changing historical paradigms. The Russian design practice is characterised by a broad scope and global vision, including the procedure for developing fundamental concepts of the world order. At the same time, the discussion of global problems is associated with the human dimension of the world order, with the development of concepts, international institutions and procedures, the object of which is human potential and various types of humanitarian activities [Genisaretsky, 1996]. It is evidenced by the statements of the leading Russian specialists in the field of conceptual design: G. Shchedrovitsky, V. Glazychev, O. Genisaretsky.

Consistency in the vision of the outlines of the future is a condition for uniting people into teams of like-minded people. Strategic design, systemic interaction of people to create a predictive concept carries a rich, creative, cultural, intellectual and spiritual potential. The team as a creative unit is no longer formed through the competencies and design skills inherent in the teamwork model but owing to the intellectual, spiritual unity, empathy of members of a team of like-minded people. The ability for spiritualised communication and like-mindedness forming on its basis is put at the forefront. "The designer was faced with traditionally 'non-design' tasks: the humanisation of relations, all-round development of personality, etc... This means the inclusion of the most diverse! specialists in a common (not by duty but by spirit) cause" [Shurov, 2011: 49].

The formation of a team of like-minded people is closely related to the organisation of the thinking process in the group. "A seminar is an action for the sake of trying to start creating other thoughts, or rather, thinking activities" [Glazychev]. In design practice, involving interdisciplinary project sessions and seminars, as well as other forms of combining professionals, competencies that confirm what a specialist knows and can do give way to principles that determine how he or she thinks. In project thinking, several types of intellectual orientation can be distinguished, which are determined by natural talent. These include various types of thinking: creative (from heuristic - to combinatorial), technical (from design - to engineering), organisational (from communicative and informational - to managerial), figurative (from metaphorical - to connotational), creative or artistic (from colour-graphic - to volumetric-spatial), futuristic (from scientific to strategic), resource (from spatial to content), organisational (from structural to managerial), and so on. At the same time, knowledge and skills, competencies 
and project experience are only a consequence of the cognitive abilities of the group members. "Design thinking is a sequence of cognitive and other operations that is considered a universal way to solve a problem" [Ro, 2016: 249]. The types of thinking with apparent closeness can appeal to entirely different cognitive abilities of a person, his or her mental dispositions and natural talents.

With a detailed segmentation of particular types of design thinking, it is essential to understand the range and capabilities of design thinking, consisting of intelligent individuals - specialists of different giftedness. "Design engineering is a meeting place and integration of the multiple experiences of the collective mind" [Freire, 2017: 92]. The exchange of energies, emotions, knowledge and approaches to design is the value and wealth of design activities. The design processes themselves take the team of like-minded people to an entirely new level of self-awareness. Here, deep-seated attitudes are manifested, which are characteristic not only of individuals but also of the collective consciousness as an integral intellectual and spiritual organism. Owing to team actions, thoughts and images are repeatedly refracted and reflected, multiplied, freed from unnecessary things, finding their only true form and meaning for a given space and time. It can be safely asserted that intellectual collective self-knowledge and self-awareness are carried out through project-based creative activity, which leads to co-evolution - joint development and all-around enrichment.
Today, co-evolution as a joint, interdependent existence and development is rarely understood as a collective resource. Competitive methods are constantly prevalent in the profession. Knowledge, skills and abilities work not for the joint result of the community but for the natural desire to stand out within the team. However, the investment of time and labour in the accumulation of competencies is meaningful only when one or another knowledge, skills and abilities are integrated into the team project field. The basic principle of win-win is the primary condition for co-evolution, high-quality joint development in a team. With an internal attitude towards team interaction, the global professional community is interpreted as an extension of the individual creative self beyond the capabilities of the individual - to a worldwide scale.

Strategic design, carried out by a team of like-minded people, as a future-oriented project concept has development prospects in our country. Russian design, which had been in the sociallyoriented, humanistic paradigm of design creativity for almost the entire 20th century, is adaptive to the social tasks of the global design of a high-quality future. Preserving and increasing human values, creating futuristic images, determining the desired place of a person in the future, developing principles of behaviour in society and organising communication between people are the real aims of work for Russian designers who want to create a harmonious world for themselves and future generations.

\section{REFERENCES}

1. Genisaretsky, O.I. On the Human Dimension of the Future World Order Congress [Electronic resource] Access mode: www.olegen.com/synergistic-anthropology/ a2/culture-russia/dimension/- congress-humandimension-b/. (access date: 05.08.2020).

2. Glazychev, V.L. Methodology for Conducting Project Seminars [Electronic resource] Access mode: http://www.glazychev.ru/projects/seminars/seminar_ metodology.htm. - (access date: 05.08.2020).

3. Jerdev, E. V. 2007. "The Role of VNIITE in the Development of Russian Industrial Design", Design Review. Information Scientific and Practical Journal. Kazan: Design-kvartal, no. 1-4, pp. 8-12.

4. Marfin, S. G. 2005. "Problem Seminars - a Way of Forming a Team of Like-minded People", Professional education. Moscow: Academia professionalnogo obrazovania, no. 4, pp. 15-16.
5. Ro, O. 2016. "Is the Evolution of Higher Education Keeping up with the Revolution of Opportunities?", Collection of materials of the International Scientific and Practical Conference Russian Creative Education in the Field of Digital Art in Accordance with EU Standards, Moscow: Stroganov MGHPA, pp. 243-256.

6. Shurov, V. A. 2011. "From 'Design Thinking' to 'Design Being'", Design Review. Information scientific and practical journal. Kazan: Design-kvartal, no. 1-2, p. 49.

7. Bell, S. T. 2015. "Selecting and Composing Cohesive Teams", Research on Managing Groups and Teams, vol. 17. Team Cohesion: Advances in Psychological Theory, Methods and Practice, pp. 181-209.

8. Bentley, D. Freelance Rates and Market Guide 2019. Australian Creative Services \& Digital Industry [Electronic resource] / Access mode: https://www.cavalryfreelancing.com/wp-content/uploads/Cavalry_Rates_ Guide_2019.pdf. (access date: 05.08.2020). 
9. Cambridge Advanced Learner's Dictionary \& Thesaurus [Electronic resource]. Access mode: https://dictionary. cambridge.org/dictionary/english/teamwork. (access date: 05.08.2020).

10. Freire, K. 2017. "From Strategic Planning to the Designing of Strategies: A Change in Favor of Strategic Design", Strategic Design Research Journal, 10 (2) São Leopoldo, RS, Brasil: Publicação da Universidade do Vale do Rio dos Sinos Unisinos, pp. 91-96.

11. Ghosh, S. 2017. Career \& Opportunities in Freelancing Kindle Edition. New Delhi, Delhi: Diamond Pocket Books, p. 110.

12. Ghuman, U. 2016. "An Empirical Examination of Group Emotional Intelligence in Public Sector Workgroups", Team Performance Management, vol. 22 (1-2), pp. 5174.

13. Grossman, R. 2015. "What Matters for Team Cohesion Measurement? A Synthesis", Research on Managing Groups and Teams, vol. 17. Team Cohesion: Advances in Psychological Theory, Methods and Practice, pp. 147-180.

14. Hirunyawipada, T. 2015. "Toward the Development of New Product Ideas: Asymmetric Effects of Team Cohesion on New Product Ideation", Journal of Business \& Industrial Marketing, vol. 30, no. 7, pp. 855-866.

15. Madden, J. R. 2015. The Collaboration Blueprint: Designing and Building Effective Strategies for Innovation and
Rejuvenative Collaboration. Cleveland, $\mathrm{OH}, \mathrm{USA}$ : Triple alumna of Case Western Reserve University, p. 223.

16. Redström, J. 2017. Making Design Theory. Cambridge, MA: The Massachusetts Institute of Technology Press, p. 170.

17. Severt, J. B. 2015. "On the Function and Structure of Group Cohesion", Research on Managing Groups and Teams, vol. 17. Team Cohesion: Advances in Psychological Theory, Methods and Practice, pp. 3-24.

18. Singh, A. Freelance Data Scientist [Electronic resource]. Access mode: https://www.researchgate.net/publication/332539068_Freelance_Data_Scientist. (access date: 05.08.2020).

19. Vanhove, A. J. 2015. "Team Cohesion and Individual Well-Being: A Conceptual Analysis and Relational Framework", Research on Managing Groups and Teams, vol. 17. Team Cohesion: Advances in Psychological Theory, Methods and Practice, pp. 53-82.

20. Vveinhardt, J. 2017. "Congruence of Personal and Organizational Values: Structuring Components of the Phenomenon", Proceedings of the $29^{\text {th }}$ International Business Information Management Association Conference Education Excellence and Innovation Management Through Vision 2020 from Regional Development Sustainability to Global Economic Growth, pp. 1003-1017. 
Юлия Анатольевна Васерчук

профессор кандидат искусствоведения

Институт современного искусства, кафедра графического дизайна

e-mail: vasse@yandex.ru

Москва, Россия

ORCID 0000-0002-0111-8874

DOI: 10.36340/2071-6818-2021-17-2-138-150

\section{ПРОЕКТНАЯ КУЛЬТУРА КОМАНДНЫХ СТРАТЕГИЙ}

Аннотация: В статье рассматриваются современные формы дизайнерской деятельности, способствующие развитию профессионального проектирования. Сопоставляются близкие по форме, но отличающиеся по содержанию принципы коллективной работы проектировщиков. В одном случае - это рабочие команды teamworks, в другом - группы единомышленников. Выявлено, что соратники объединяются под флагом общих ценностей, смыслов, мировоззренческих установок для формирования картины будущего и постановки глобального видения стратегий профессиональной деятельности, проектных принципов, методик и установок, нацеленных на повышение качества жизни. Совместными интеллектуальными и духовными усилиями единомышленники формируют вектор современной дизайнерской деятельности. Профессиональная элита выступает движущей силой эволюционного преобразования современного дизайна, выявляет потенциал осознанного дизайн-проектирования, развитого дизайн-мышления, определяет место дизайна в профессиях будущего, задаёт нравственные эталоны поведения.

Типы проектного дизайн-мышления (от инженерного, креативного - до художественного и ресурсного)

Дизайн в современной практике зачастую представлен индивидуальной формой проектной деятельности, о чём свидетельствует значительный рост объёмов удалённой работы и фриланса. Спрос на фрилансеров в крупных организациях с 2017 по 2020 год удвоился [Bentley, 2019]. Фрилансер может внести свой вклад в компанию, не будучи её частью [Singh, 2019]. Такие люди способны изменить состояние компаний, позволяя им значительно расширяться для удовлетворения возросшего спроса или дополнять командную работу опытом, который в противном случае компании никогда не смогли бы получить или оправдать [Bentley, 2019]. представлены в виде результатов индивидуального творчества участников команды. Непрерывное развитие тех или иных областей проектного дизайн-мышления и обретение компетенций, исходя из индивидуальных возможностей, обеспечивает проектировщикам долгосрочное профессиональное развитие вне зависимости от внешних условий. Более того, честное отношение к себе и своим способностям содействует глубокому пониманию профессии, что позволяет развиваться новым видам дизайна, отвечающим на глубинные человеческие запросы.

В завершении делается вывод, что самопознание, обретаемое в коллективном творческом акте, содействует раскрытию индивидуальных способностей и ведёт к интеллектуальной и духовной коэволюции.

Ключевые слова: Проектная культура дизайна, команда, коллектив единомышленников, teamwork, фриланс, коллективное дизайн-проектирование, компетенции, типы мышления, стратегия, концептуальный дизайн, проектное дизайн-мышление, коэволюция, отечественный дизайн.

Определяя принципы фриланса, важно понимать, что такая работа предполагает удалённое, но, тем не менее, достаточно плотное взаимодействие с коллегами. Удалённо можно проектировать, находясь в любом месте, но дистанцированность не означает отрыв от коммуникаций. Чтобы зарабатывать, фрилансеру необходимы партнёры. Таким образом, фриланс - не настолько изолированный тип деятельности, как это может показаться [Ghosh, 2017]. Тем не менее, дизайнер, особенно если он работает удалённо, редко рассматривается как командный игрок в коллективе проектировщиков. Его не привлекают для создания командных стратегий, интеллектуальный 
потенциал фрилансера редко используют в принципиальных разработках. В современном мире ценятся способности дизайнера визуализировать уже сформированный образ, реализовывать чужое видение. Стратеги от маркетинга возглавили процесс проектирования и осуществляют выбор направлений исходя из потребительских предпочтений, а порой и активно их формируя.

Развитие фриланса, позиционирование дизайна как индивидуальной творческой деятельности, а также миф о том, что дизайн - профессия для интровертов, в известном смысле мешают развитию коллективных форм проектирования, не позволяют дизайнерам осознавать себя частью команды, мешают профессионалам стать активными участниками коллективного интеллектуального сотворчества. Только часть дизайнеров осознаёт, что командное проектирование превосходит возможности индивидуального благодаря своему многоаспектному охвату, обогащающему конечные результаты деятельности. Ресурс командной работы в дизайне до конца не выявлен и не актуализирован в полной мере. В реальности, даже вследствие распространения фриланса и прочих "некомандных» форматов работы, дизайн имеет все возможности для реализации практик групповой деятельности, внедрения междисциплинарных проектных сессий, развития инструментов проектирования в русле креативных командных технологий.

Пандемия covid-19 и связанная с ней самоизоляция в полной мере продемонстрировали весной 2020 года, что удалённые способы взаимодействия не мешают продуктивной коллективной работе во многих профессиональных сферах, в том числе и в сфере дизайна. Проектные сессии, семинары, организуемые на платформах Skype, Webinar, Webex, Zoom и пр., в непростой для всех период позволили специалистам сплотиться для решения актуальных задач дизайна и бизнеса и укрепить человеческие связи, развить межличностное общение.

В современном мире при возрастании уровня стресса на первый план выходит фактор психологической поддержки в виде добровольного союза людей. Эта естественная реакция общества купирует разобщённость, компенсирует дефицит качественного общения, содействует возникновению и укреплению единомыслия. При этом согласие рассматривается не только как интеллектуальное, но и как психически-эмоциональное, духовное единение. Особое значение имеет человеческий капитал, которому команда служит поддержкой и опорой, так как многократно умножается ценность индивидуального вклада в общее дело всех участников. Команда является организмом, объединяющем людей не только общим делом, но и общим духом.

В настоящее время распространено понятие «Teamwork», что означает способность группы людей хорошо работать вместе [Cambridge Advanced Learner's Dictionary, 2019], а также оно включает в себя работу по достижению общих целей и выполнению задач наиболее адекватным и действенным способом группой взаимосвязанных людей, командой. Слово «работа» (work) в понятии teamwork является ключевой, смыслообразующей основой фразы. При эффективной командной работе учитываются знания, навыки, способности и другие характеристики её членов [Bell, 2015: 181]. Сплочённость группы является одним из наиболее исследуемых конструктов, влияющих на эффективность команды, её производительность [Severt, 2015: 3], и вносит значительный вклад в командный успех. Исследования механизмов сплочённости позволяют диагностировать, контролировать и улучшать показатели команды [Grossman, 2015: 147]. Особое внимание уделяется двум критериям командной сплоченности - организационной приверженности членов команды и их социальной компетентности [Hirunyawipada, 2015: 855], а также факторам эффективности, основанным на благополучии: субъективном благополучии (subjective well-being SWB) и психологическом благополучии (psychological well-being PWB) [Vanhove, 2015: 53]. Межличностные отношения членов команды, такие как, например, дружба, не имеют положительной связи с согласованностью задач и желательной квалификацией созданных группой идей [Hirunyawipada, 2015: 855]. Однако положительная связь наблюдается между командной эффективностью и эмоциональным настроем группы. Объединения, которые развивают групповое эмоциональное сознание и могут управлять эмоциональными отношениями внутри группы, становятся более продуктивными и способными к обучению [Ghuman, 2016: 51]. Для модели командной работы teamwork профессиональные, деловые отношения, сформированные в целях оптимального решения корпоративных задач, являются определяющими, а эмоциональная близость - эмпатия - представляется своего 
рода «подушкой безопасности» в межличностных связях.

В отечественной практике помимо уместной для деловых отношений модели teamwork сформировалась форма объединения людей по принципу единомыслия, которая по факту выходит за рамки простого единения участников со схожей ментальностью и образом мыслей, а подразумевает сплочённость на более глубоком духовном уровне. Эмоциональное единение и творческая атмосфера представляются не только инструментами, формирующими сплочённость, но и деловыми интенциями профессиональных групп, экзистенциальным смыслом их творчества. В большинстве случаев люди встречаются, объединяются ради взаимоподдержки и взаимопомощи. Зачастую общее дело является лишь предлогом для командного взаимодействия. Корифей отечественной проектной культуры В.Л. Глазычев отмечал, что «на семинаре люди сходятся вместе, и между ними происходит взаимный обмен, и не так уже важно, возникнет ли здесь и сейчас какой-либо проект или нет. Возникнет - прекрасно, если нет, то ничего страшного: значит, возникнет в следующий раз. Важно, что появился другой опыт. Участники посмотрели на других людей, услышали другие мнения, увидели другие подходы, и это очень важно... Опыт передаётся только так - от человека к человеку» [Глазычев]. Значимым представляется наличие доброй воли в профессиональных творческих объединениях и союзах. Люди готовы на встречи и проектные сессии, имея внутреннюю мотивацию, заинтересованность в инновационном развитии дизайна, в обогащении отрасли, её индивидуальном развитии в процессе обретения совместного опыта. Совместное «проживание» творческого процесса в коллективе близких по духу людей в значительной мере обогащает всех его участников, наполняет их жизнь энергией.

«Коллектив единомышленников» - представляется наиболее точным определением для подобного рода команды. При этом единомышленники - люди, объединённые общим интеллектуальным и культурным уровнем, схожим вектором духовного развития, разделяющие схожие ценности и мировоззренческие установки. Данная культурная особенность всегда была некоторой преградой для быстрого и успешного внедрения в отечественные проектные процессы западных бизнес-моделей, форм организации и управления проектной деятельностью, деловых коммуникаций и стандартов teamwork. Совместное проектирование в нашей стране чаще всего строится на принципах открытости, рефлективности, а самое главное - создания инновационных проектов, методических разработок, других «продуктов» коллективной мыследеятельности, обогащающих практику [Марфин, 2005: 15]. Представителям профессиональной среды (высшей школы, дизайнерской практики) всегда было важно договориться об общих «точках схода» и далее выстраивать методологический каркас дизайна, опираясь на зрелую понятийную базу при всём многообразии индивидуальных теоретических разработок и практического опыта.

Современные отечественные проектировщики ещё помнят и чтут традиции художественного конструирования, теоретический и методологический опыт Всероссийского научно-исследовательского института технической эстетики (ВНИИТЭ), знаменитые на весь Советский Союз проектные семинары Института, конференции, издания, ориентированные «на развитие творческой рефлексии, выработку профессионально-критического подхода к результатам собственной деятельности, видение её объектов в широком социально-культурном контексте» [Жердев, 2007: 8]. Результаты коллективной проектной деятельности содержатся в многочисленных отчётах о научнометодической работе Института, в методических рекомендациях по итогам проектных семинаров, в материалах международных и отечественных научных конференций, в предпроектной и проектной документации: пояснительных записках к художественно-конструкторским предложениям, в докладах о результатах экспертизы отечественной и зарубежной дизайнерской продукции.

Коллективная работа teamwork несколько отличается от традиционных для постсоветского пространства форм проектного сотворчества. В первую очередь этот водораздел проходит через область целеполагания, создающую корпоративные стратегии и прогрессивные бизнес-решения. Для отечественных моделей сотворчества целеполагание, как правило, руководствуется принципом - «сделать мир лучше». Также отличительной чертой является метод подбора специалистов в команды. Для коллектива единомышленников дружба и человеческое приятие являются значимыми мотивами единения. Модель teamwork предполагает интеграцию членов команды по принципу «конструктора», 
стыкующего знания, умения и навыки, необходимые для разработки проекта. Для успешной работы формируются группы людей с компетенциями в нескольких дисциплинах и дополнительными навыками, позволяющими профессионалам работать, слушать и учиться друг у друга при совместном решении задач [Redström, 2017: 11]. Комбинаторный принцип моделирования команд, основанный на компетенциях и проектном опыте участников, способствует объединению людей для реализации проектов разной направленности. Короткие дистанции, успешно пройденные командой совместно, предполагают дальнейшее развитие и трансформацию команд в новые объединения с целью прохождения следующих дистанций. Взаимозаменяемость и гибкость команд, сформированных на компетентностной основе, дают возможность людям знакомиться, обмениваться опытом и знаниями, расширять кругозор и учиться эффективно взаимодействовать с представителями разных областей деятельности. В зависимости от состава созданной команды участники групп каждый раз ищут новый метод результативного решения задач, осуществляют личностный рост, развивают персональные качества руководителя. Лидеры успешного сотрудничества демонстрируют повышенную эмоциональную и социальную компетентность, предпринимают действия, направленные на улучшения и прогресс в будущем, остаются ориентированными на миссию и готовы к изменениям для решения текущих задач [Madden, 2015: 18].

Важным фактором, влияющим на эффективность проектной работы teamwork, является согласованность ценностного ряда её участников с общими преференциями корпораций-заказчиков. «Восприятие различных типов ценностей и их проявление было бы полезно руководителям в понимании того, как выявлять причины разрыва между личными ценностями сотрудников и ценностями организации и предпринимать целенаправленные действия для обеспечения соответствия ценностей внутри компаний» [Vveinhardt, 2017: 2003]. Управление ценностными моделями в западных формах коллективной работы служит, как правило, стратегическим целям компаний и парадигме рыночной экономики в целом. Командное проектирование при условии соблюдения согласованных ценностей стало сегодня для зарубежных и многих отечественных компаний драйвером успешных проектных разработок в области развития брен- дов, отдельных продуктов, услуг и направлений бизнеса. Командная работа teamwork для дизайна - это эффективный инструмент поиска решений, включающих исследования, ориентированные на конечного пользователя, в целях создания прототипов будущих успешных дизайнрешений, а также коллективное творчество для укрепления отдельных лиц, команд и организаций [Madden, 2015: 18]. Стратегический дизайн, опирающийся на командную работу teamwork, зарекомендовал себя как эффективное оружие в конкурентной борьбе, он вывел методы проектирования на уровень создания социальных предпосылок для появления востребованных товаров и услуг. Он стал способен через продукты и услуги, модели потребительского поведения и коммуникации воздействовать на общество, экологию, демографию и прочие сферы жизни.

Для отечественной проектной мысли cmpameгия видится как нечто более комплексное и выходящее за рамки решения конкретных бизнес-задач отдельно взятых корпораций. Тактический уровень социального проектирования также воспринимается недостаточным при отсутствии глобальной проектной философии. Для коллективов единомышленников базовым фактором объединения людей является согласованность ценностного ряда, общность глубинных мировоззренческих установок, единое понимание целей и смыслов совместной интеллектуальной и проектной деятельности. Такой подход способствует совместному прохождению долгосрочных дистанций, также у него есть высокий потенциал для развития комплексного стратегического проектирования и формирования проектной философии. Согласованность фундаментальных основ и смыслов дизайна как проектной технологии будущего позволяет коллективу единомышленников осуществлять проектирование, исходя из общей ценностной парадигмы на сколь угодно долгую перспективу.

Западная корпоративная культура, деловые коммуникации, форматы teamwork подчас выглядят легковесными для людей, выросших в советскую и постсоветскую эпоху. Корпоративная культура часто становится в России объектом насмешек, поскольку не достигает уровня истинной культуры как комплекса филантропии, благородства и интеллигентности в привычном для соотечественников смысле. Для осуществления комплексной стратегической проектной деятельности необходима 
команда единомышленников, объединённых духовными ценностями и общим желанием изменить мир к лучшему. Подобная глобальность проектных установок сформирована революционным духом сменяющихся исторических парадигм. Для отечественной проектной практики свойственен широкий охват и глобальное видение, включающие процедуру формирования принципиальных концепций мироустройства. При этом обсуждение глобальных проблем связано с человеческим измерением мирового порядка, с выработкой концепций, международных институтов и процедур, объектом которых является - человеческий потенциал и различные виды гуманитарной деятельности [Генисаретский, 1996]. Об этом свидетельствуют высказывания ведущих отечественных специалистов в области концептуального проектирования: Г.П. Щедровицкого, В.Л. Глазычева, О.И. Генисаретского.

Согласованность в видении очертаний будущего является условием объединения людей в команды единомышленников. Стратегическое проектирование, системное взаимодействие людей с целью создания прогностической концепции - несёт в себе богатый творческий, культурный, интеллектуальный и духовный потенциал. Команда как творческая единица формируется уже не через компетенции и проектные навыки, свойственные модели teamwork, но благодаря интеллектуальному, духовному единству, эмпатии членов коллектива единомышленников. Способность к одухотворённому общению и созревающему на этой базе единомыслию ставится во главу угла. «Перед дизайнером встали традиционно «недизайнерские» задачи: гуманизация отношений, всестороннее развитие личности и т.д. ...Это означает включение самых разнообразных! специалистов в общее (не по долгу, а по духу) дело» [Шуров, 2011: 49].

Формирование команды единомышленников тесно связано с организацией процесса мышления в группе. «Семинар есть действие ради попытки начать создавать другие мысли, а вернее, мыследеятельности» [Глазычев]. В дизайнерской практике, предполагающей междисциплинарные проектные сессии и семинары, а также иные формы объединения профессионалов, компетенции, подтверждающие, что специалист знает и умеет, уступают место принципам, определяющим то, как он мыслит. В проектном мышлении можно выделить целый ряд типов интеллектуальной направленности, которые определяются природным дарованием. К ним относятся различные типы мышления: креативное (от эвристического до комбинаторного), техническое (от конструкторского - до инженерного), организационное (от коммуникативно-информационного - до управленческого), образное (от метафорического - до коннотационного), творческое или художественное (от цвето-графического - до объёмно-пространственного), футуристическое (от научного - до стратегического), ресурсное (от пространственного - до контентного), организационное (от структурного - до управленческого) и т.д. При этом знания и умения, компетенции и проектный опыт являются лишь следствием когнитивных способностей участников группы. «Дизайн-мышление - это последовательность когнитивных и других операций, которая считается универсальным способом решать задачу» [Ро, 2016: 249]. Типы мышления при кажущейся близости могут апеллировать к совершенно разным когнитивным способностям человека, его ментальным предрасположенностям и природным талантам.

При детальной сегментации частных видов дизайн-мышления представляется важным общее понимание диапазона и возможностей проектного мышления, состоящего из интеллектуальных индивидов - специалистов разной одарённости. «Дизайн-проектирование - это место встречи и интеграции многочисленного опыта коллективного разума» [Freire, 2017: 92]. Обмен энергиями, эмоциями, знаниями и подходами к проектированию является ценностью и богатством проектной деятельности. Сами процессы проектирования выводят команду единомышленников на совершенно новый уровень самосознания. Здесь проявляются глубинные установки, свойственные не только индивидуумам, но и коллективному сознанию как целостному интеллектуальному и духовному организму. Благодаря командным действиям мысли и образы многократно преломляются и отражаются, умножаются, избавляются от лишнего, находя свои единственно верные для данного пространства и времени форму и смысл. Можно смело утверждать, что интеллектуальное коллективное самопознание и самоосознание осуществляются посредством проектной творческой деятельности, что ведёт к коэволюции - совместному развитию и всестороннему обогащению.

Коэволюция - совместное, взаимообусловленное существование и развитие - сегодня редко 
понимается как коллективный ресурс. Методы конкурентной борьбы постоянно превалируют в профессии. Знания, умения и навыки работают не на совместный результат сообщества, а на естественное желание выделиться внутри коллектива. Однако инвестиции времени и труда в накопление компетенций являются осмысленными только при интеграции тех или иных знаний, умений и навыков в командное проектное поле. Базовый принцип win-win (выиграть-выиграть) является основным условием коэволюции, качественного совместного развития в команде. При внутренней установке на командное взаимодействие глобальное профессиональное сообщество интерпретируется уже как расширение индивидуального творческого Я за пределы возможностей индивида - до глобальных масштабов.
Стратегический дизайн, осуществляемый командой единомышленников, как ориентированная на будущее проектная концепция имеет перспективы развития в нашей стране. Отечественный дизайн, почти весь XX век пребывавший в социально-ориентированной, гуманистической парадигме проектного творчества, адаптивен к социальным задачам глобального конструирования качественного будущего. Сохранение и преумножение человеческих ценностей, создание футуристических образов, определение желаемого места человека в будущем, разработка принципов поведения в обществе и организация коммуникации между людьми - вот реальный фронт работы для российских дизайнеров, желающих создать гармоничный мир для себя и будущих поколений.

\section{БИБЛИОГРАФИЯ}

1. Генисаретский О.И. О конгрессе «Человеческое измерение будущего миропорядка» [Электронный ресурс] / О.И. Генисаретский.- Режим доступа: www.olegen.com/синергийная-антропология/ а2/культура-россии/измерение/о-конгрессечеловеческое-измерение-б/.- (Дата обращения: 05.08.2020).

2. Глазычев В.Л. Методология проведения проектных семинаров [Электронный ресурс] / В. Л. Глазычев.Режим доступа: http://www.glazychev.ru/projects/seminars/seminar_metodology.htm. - (Дата обращения: 05.08.2020).

3. Жердев Е.В. Роль ВНИИТЭ в развитии российского промышленного дизайна / Е.В. Жердев // Дизайн Ревю. Информационный научно-практический журнал. - Казань: Дизайн-квартал, 2007.№ 1-4.- С. 8-12.

4. Марфин С.Г. Проблемные семинары - способ формирования коллектива единомышленников / С. Г. Марфин // Профессиональное образование.М.: Академия профессионального образования, 2005. - № 4.- С. 15-16.

5. Ро О. Успевает ли эволюция высшей школы за революцией возможностей? / Ольга Ро, Елена Фотьянова // Сборник материалов Международной научно-практической конференции «Российское креативное образование в области цифрового искусства в соответствии со стандартами ЕС» / Под ред. А.Н. Лаврентьева.- М.: МГХПА им. С. Г. Строганова, 2016. - С. 243-256.

6. Шуров В.А. От «дизайн-мышления» к «дизайнбытию» / В.А. Шуров // Дизайн Ревю. Информационный научно-практический журнал.Казань: Дизайн-квартал, 2011. - № 1-2.- С. 49.
7. Bell S.T. Selecting and Composing Cohesive Teams / Suzanne T. Bell, Brown G. Shanique // Research on Managing Groups and Teams. - 2015. - Volume 17. Team Cohesion: Advances in Psychological Theory, Methods and Practice. - P. 181-209.

8. Bentley D. Freelance rates and market guide 2019. Australian creative services \& digital industry [Электронный ресурс] / Dave Bentley. - Режим доступа: https://www.cavalryfreelancing.com/wp-content/uploads/Cavalry_Rates_Guide_2019.pdf. - (Дата обращения: 05.08.2020).

9. Cambridge Advanced Learner's Dictionary \& Thesaurus [Электронный ресурс]. - Режим доступа: https://dictionary.cambridge.org/dictionary/english/teamwork. (Дата обращения: 05.08.2020).

10. Freire $K$. From strategic planning to the designing of strategies: A change in favor of strategic design / Karine de Mello Freire // Strategic Design Research Journal, 10 (2) São Leopoldo, RS, Brasil: Publicação da Universidade do Vale do Rio dos Sinos — Unisinos, 2017.— P. 91-96.

11. Ghosh S. Career \& Opportunities in Freelancing Kindle Edition / Soumen Ghosh. - New Delhi, Delhi: Diamond Pocket Books, 2017. - 110 p.

12. Ghuman $U$. An empirical examination of group emotional intelligence in public sector workgroups / Umar Ghuman // Team Performance Management. 2016. - Volume 22 (1-2). - P. 51-74.

13. Grossman R. What Matters for Team Cohesion Measurement? A Synthesis / Rebecca Grossman, Zachary Rosch, David Mazer, Eduardo Salas // Research on Managing Groups and Teams. - 2015. - Volume 17. Team Cohesion: Advances in Psychological Theory, Methods and Practice. - P. 147-180. 
14. Hirunyawipada $T$. Toward the development of new product ideas: asymmetric effects of team cohesion on new product ideation / Tanawat Hirunyawipada, Audhesh K. Paswan, Charles Blankson // Journal of Business \& Industrial Marketing. - 2015. - Vol. 30 No. 7.- P. 855-866.

15. Madden J.R. The Collaboration Blueprint: Designing and Building Effective Strategies for Innovation and Rejuvenative Collaboration / Jennifer R. Madden.Cleveland, $\mathrm{OH}$, USA: Triple alumna of Case Western Reserve University, 2015. - 223 p.

16. Redström J. Making design theory / Johan Redström. Cambridge, MA: The Massachusetts Institute of Technology Press, 2017. - 170 p.

17. Severt J. B. On the Function and Structure of Group Cohesion / Jamie B. Severt, Armando X. Estrada // Research on Managing Groups and Teams. - 2015. Volume 17. Team Cohesion: Advances in Psychological Theory, Methods and Practice. - P. 3-24.
18. Singh A. Freelance Data Scientist [Электронный ресурc] / Ajit Singh. - Режим доступа: https://www. researchgate.net/publication/332539068_Freelance_ Data_Scientist. - (Дата обращения: 05.08.2020).

19. Vanhove A.J. Team Cohesion and Individual WellBeing: A Conceptual Analysis and Relational Framework / Adam J. Vanhove, Mitchel N. Herian // Research on Managing Groups and Teams. - 2015. - Volume 17. Team Cohesion: Advances in Psychological Theory, Methods and Practice. - P. 53-82.

20. Vveinhardt J. Congruence of personal and organizational values: Structuring components of the phenomenon / Jolita Vveinhardt, Rizwan Raheem Ahmed, Evelina Gulbovaite // Proceedings of the $29^{\text {th }}$ International Business Information Management Association Conference Education Excellence and Innovation Management Through Vision 2020 from Regional Development Sustainability to Global Economic Growth. - 2017. P. 1003-1017. 

Журнал зарегистрирован в государственном комитете РФ по печати. Свидетельство о регистрации СМИ - ПИ № ФС77-27658

от 30 марта 2007.

Полнотекстовая электронная версия доступна на сайтах: www.burganova-text.com,

www.elibrary.ru

Подписка на журнал во всех отделениях связи России и стран СНГ.

Подписной индекс 36947

Иллюстрации публикуются в соответствии со статьей 1274

гражданского кодекса РФ «Свободное использование произведения в информационных, научных, учебных или культурных целях»

Информация для авторов, условия приема публикации на сайте: www.burganova-text.com

Переводчик Анна Пчелкина

Верстка Александр Товпеко

Журнал выходит 4 раза в год

Адрес редакции:

119019, Москва, Б. Афанасьевский переулок, д. 15, стр. 9

Тел.: 8495 695-04-29

www.burganova-text.com

dom.text@gmail.com

Тираж 500 экз. 
Journal Burganov House. Space of Culture is registered in State Press

Committee of the Russian Federation on March 30, 2007.

The mass media registration certificate ПИ № ФС 77-27658

The journal is in the List of peer-reviewed scientific publications of the Higher Attestation Commission of the Ministry of education and science of the Russian Federation

Full-text electronic version is available at the sites:

www.burganova-text.com,

www.elibrary.ru

Subscription to the journal in all post offices of Russia and the CIS countries. Subscription index under the catalogue

"Post of Russia" is 36947

Illustrations are published in accordance with Article 1274 of the The Russian Civil Code "Free Use of the Work for informational, scientific, educational or cultural purposes"

Information for authors, conditions for accepting publications is on the site: www.burganova-text.com

Translator Anna Pchelkina

Layout Alexander Tovpeko

The journal is published 4 times a year

Editorial office address in Russia:

Russia, Moscow. 19019, B. Afanasyevsky lane, d. 15, p. 9

tel .: 007495 695-04-29

Editorial office address in EU:

Belgium, Brussels, 1000, rue de la tete d'or, 7

tel .: +32 485681863

www.burganova-text.com

dom.text@gmail.com

Circulation: 500 copies 
